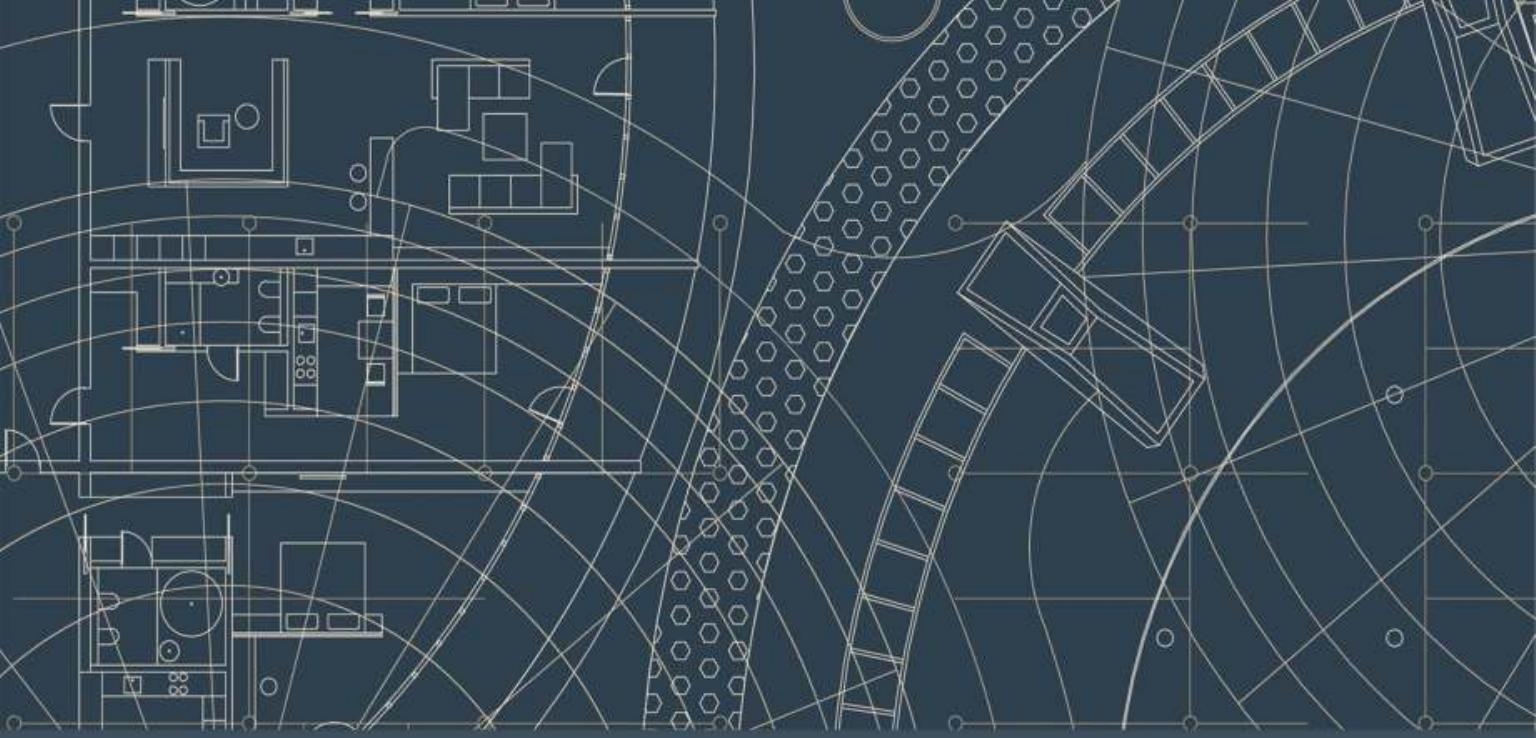

Asia's Transformations

\title{
POPULAR CULTURE AND THE TRANSFORMATION OF JAPAN-KOREA RELATIONS
}

Edited by

Rumi Sakamoto and Stephen Epstein
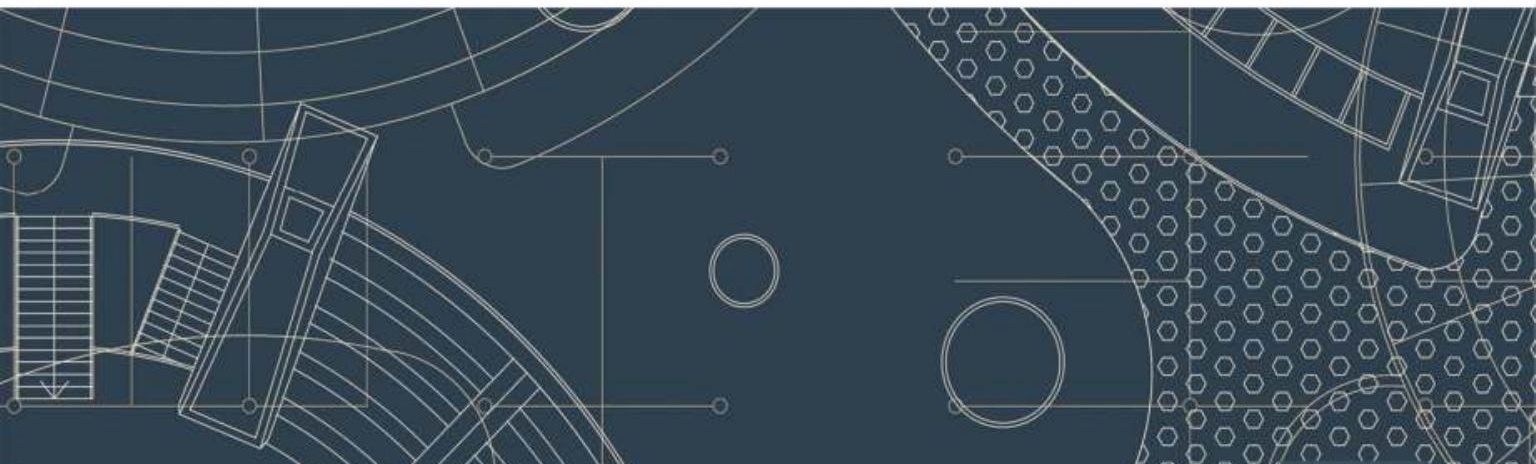


\section{Popular Culture and the Transformation of Japan-Korea Relations}

This book presents essays exploring the ways in which popular culture reflects and engenders ongoing changes in Japan-Korea relations.

Through a broad temporal coverage from the colonial period to the contemporary, the book's chapters analyse the often contradictory roles that popular culture has played in either promoting or impeding nationalisms, regional conflict and reconciliations between Japan and Korea. Its contributors link several key areas of interest in East Asian Studies, including conflicts over historical memories and cultural production, grassroots challenges to state ideology, and the consequences of digital technology in Japan and South Korea.

Taking recent discourse on Japan and South Korea as popular cultural superpowers further, this book expands its focus from mainstream entertainment media to the lived experience of daily life, in which sentiments and perceptions of the "popular" are formed. It will be useful to students and scholars of Japanese and Korean studies, as well as film studies, media studies and cultural studies more widely.

Rumi Sakamoto is Senior Lecturer in Japanese at the School of Cultures, Languages and Linguistics, the University of Auckland, and is convenor of Asian Studies, Chinese, Japanese and Korean programmes. She has published widely on Japanese popular culture, nationalism and war memory. She is a co-editor of Popular Culture, Globalization and Japan (Routledge, 2006) and Japanese Popular Culture (Routledge, 2014). Her current research looks at cultural representations of kamikaze pilots and self-defence forces in post-war Japan.

Stephen Epstein is the Director of the Asian Languages and Cultures Programme at Victoria University of Wellington in New Zealand, and served as the 2013-14 President of the New Zealand Asian Studies Society. He has published widely on contemporary Korean society, literature and popular culture and translated numerous pieces of Korean and Indonesian fiction, including the novels Who Ate Up All the Shinga? by Park Wan-suh (2009) and The Wandering by Intan Paramaditha (2020). He has co-produced two documentaries on the Korean indie music scene, Us \& Them: Korean Indie Rock in a K-pop World (2014) and Our Nation: A Korean Punk Rock Community (2002). 


\section{Asia's Transformations \\ Edited by Mark Selden \\ Cornell University, USA}

The books in this series explore the political, social, economic and cultural consequences of Asia's transformations in the twentieth and twenty-first centuries. The series emphasises the tumultuous interplay of local, national, regional and global forces as Asia bids to become the hub of the world economy. While focusing on the contemporary, it also looks back to analyse the antecedents of Asia's contested rise.

\section{Danger, Development and Legitimacy in East Asian Maritime Politics} Securing the Seas, Securing the State Christian Wirth

\section{Denying the Comfort Women}

The Japanese State's Assault on Historical Truth

Edited by Rumiko Nishino, Puja Kim and Akane Onozawa

53 National Identity, Language and Education in Malaysia

Search for a Middle Ground between Malay Hegemony and Equality

Noriyuki Segawa

\section{Japan's Future and a New Meiji Transformation}

International Reflections

Edited by Ken Coates, Kimie Hara, Carin Holroyd and Marie Söderberg

\section{Dangerous Memory in Nagasaki}

Prayers, Protests and Catholic Survivor Narratives

Gwyn McClelland

\section{Popular Culture and the Transformation of Japan-Korea Relations Rumi Sakamoto and Stephen Epstein}

For more information about this series, please visit: www.routledge.com/AsiasTransformations/book-series/SE0401 


\section{Popular Culture and the Transformation of Japan-Korea Relations}

Edited by Rumi Sakamoto and Stephen Epstein 
First published 2021

by Routledge

2 Park Square, Milton Park, Abingdon, Oxon OX14 4RN

and by Routledge

52 Vanderbilt Avenue, New York, NY 10017

Routledge is an imprint of the Taylor \& Francis Group, an informa business

(C) 2021 selection and editorial matter, Rumi Sakamoto and Stephen Epstein; individual chapters, the contributors

The right of Rumi Sakamoto and Stephen Epstein to be identified as the authors of the editorial material, and of the authors for their individual chapters, has been asserted in accordance with sections 77 and 78 of the Copyright, Designs and Patents Act 1988.

With the exception of Chapter 3, no part of this book may be reprinted or reproduced or utilised in any form or by any electronic, mechanical, or other means, now known or hereafter invented, including photocopying and recording, or in any information storage or retrieval system, without permission in writing from the publishers.

Chapter 3 of this book is available for free in PDF format as Open Access from the individual product page at www.routledge.com. It has been made available under a Creative Commons Attribution-Non CommercialNo Derivatives 4.0 license.

Trademark notice: Product or corporate names may be trademarks or registered trademarks, and are used only for identification and explanation without intent to infringe.

British Library Cataloguing-in-Publication Data

A catalogue record for this book is available from the British Library

Library of Congress Cataloging-in-Publication Data

Names: Sakamoto, Rumi, editor. | Epstein, Stephen J., 1962- editor.

Title: Popular culture and the transformation of Japan-Korea relations /

edited by Rumi Sakamoto and Stephen Epstein.

Description: London; New York, NY : Routledge/Taylor \& Francis

Group, 2020. | Series: Asia's transformations | Includes bibliographical references and index. | Identifiers: LCCN 2020011402 |

ISBN 9780367024444 (hardback) | ISBN 9780367520250 (paperback) |

ISBN 9780429399558 (ebook)

Subjects: LCSH: Korea (South)-Relations-Japan. | Japan-Relations-

Korea (South) | Popular culture-Japan. | Popular culture-Korea (South)

Classification: LCC DS849.K6 P66 2020 | DDC 303.48/45195052-dc23

LC record available at https://lccn.loc.gov/2020011402

ISBN: 978-0-367-02444-4 (hbk)

ISBN: 978-0-429-39955-8 (ebk)

Typeset in Times New Roman

by Wearset Ltd, Boldon, Tyne and Wear 


\section{Contents}

List of figures vii

Notes on contributors viii

Acknowledgements $\quad \mathrm{x}$

Notes on romanisation and names $\quad \mathrm{xi}$

Introduction: popular culture and the transformation of Japan-Korea relations

RUMI SAKAMOTO AND STEPHEN EPSTEIN

\section{PART I}

Transforming Japan-Korea relations in everyday practice

1 Colonial timekeeping: bringing Koreans up to speed ROALD MALIANGKAY

2 "Dye for my grey hair and curry powder for cooking": informal politics of exchange between North Korea and Japan, 1959-1975

3 The "Shiba view of history" and Japan-Korea relations: reading, watching and travelling Clouds Above the Hill PHILIP SEATON

PART II

Reimagining Japan-Korea relations in film

4 Remembering to reset: representations of the colonial era in recent Korean films 
vi Contents

5 Korean kamikaze pilots in Japanese films

RUMI SAKAMOTO

6 Memories of comfort: postcolonial production and consumption of Koreeda Hirokazu's Air Doll (2009)

KUKHEE CHOO

\section{PART III}

Japan-Korea relations and popular culture manipulations

7 The Diary of Yunbogi and Japan-Korea relations

CHRIS PERKINS

8 "Imjin River" and the transnational consumption of partitioned Korea

SUNHEE KOO

9 Industrial miracle or Hell Island? Gunkanjima, television, and nationalism in South Korea and Japan

YOOJIN CHOI

PART IV

Japan-Korea relations and popular culture engagement

10 Lovers' quarrels: Japan-Korea relations in amateur Boys' Love manga

REBECCA SUTER

11 Fly the flag (at your own risk): netizens, nationalism and celebrities between South Korea, Japan and beyond

STEPHEN EPSTEIN

12 Japanese inherited responsibility, popular narratives and memory of the war

RIA SHIBATA

Index 


\section{Figures}

2.1 Niigata. Store located in the Red Cross Centre 36

2.2 Niigata harbour, Japan. Repatriation to North Korea of Koreans living in Japan $\quad 37$

6.1 Inflated sex doll Nozomi in her owner Hideo's bed 98

6.2 Nozomi exploring her neighbourhood 99

6.3 Bae Doona and Koreeda Hirokazu appear on the popular television show Waratte iitomo with the host Tamori on 14 September 2009. The caption reads "Hallyu actress Bae Doona" 100

12.1 Historical awareness of Japan's wartime atrocities 185

$\begin{array}{ll}12.2 & \text { Association with the Asia-Pacific War } \\ 189\end{array}$

12.3 Information sources on war history 190

12.4 Inherited responsibility for Japan's historical injustices 193 


\section{Contributors}

Markus Bell is a migration and social inclusion expert who has published broadly on politics and social change in East Asia. He has lectured at the Australian National University, Goethe University Frankfurt, and the University of Sheffield. He is currently an Honorary Research Fellow at La Trobe University and consults for Rapid Asia.

Yoojin Choi recently graduated with a Master of Arts in Asian Studies from the University of Auckland. Her research interests include public history, war memory, and nationalism in post-war East Asia. She is currently studying Chinese at Peking University.

Kukhee Choo is Affiliate Faculty at Hosei University, and her research focuses on globalization and cultural policies, Trans-Asian media flows, and media representations of bodies. She has published work in Women: A Cultural Review (2008), Postscript (2009), Television \& New Media (2011), Mechademia (2014), Culture, Theory and Critique (2018) and various anthologies.

Sunhee Koo is a Senior Lecturer in Anthropology at the University of Auckland. Her research focuses on East Asian performing arts, through which she explores themes of ethnicity, nation, and identities. She has published articles based on ethnographic research on Korean migration in such venues as Journal of Asian Studies, Korean Studies, Asian Music, and the Yearbook for Traditional Music. Her works demonstrate how expressive arts like music and dance manifest social and cultural collisions and convergences in late modernity characterised by transnational movements.

Hee-seung Irene Lee holds a PhD in Film and Media Studies from the University of Auckland, where she now teaches. Irene's doctoral research on screen adaptation investigates the fundamental link between literature and cinema from a psychoanalytic perspective, and her thesis is currently in the final stages of preparation for publication as monograph. Her research on contemporary South Korean cinema has appeared in a range of international publications, including Journal of Japanese and Korean Cinema and edited volumes. 
Roald Maliangkay is Associate Professor in Korean Studies at the Australian National University. Fascinated by the mechanics of cultural policy and the convergence of major cultural phenomena, Roald analyses cultural industries, performance, and consumption in Korea from the early twentieth century to the present. He is author of Broken Voices: Postcolonial Entanglements and the Preservation of Korea's Central Folksong Traditions (2017), and coeditor of K-pop - The International Rise of the Korean Music Industry (Routledge, 2015).

Chris Perkins is Senior Lecturer in Japanese at the University of Edinburgh. He has published widely on pre- and post-war Japanese political movements and the media. His book on media and memory of the radical left in Japan, The United Red Army on Screen, appeared in 2015.

Philip Seaton is a Professor in the Institute of Japan Studies, Tokyo University of Foreign Studies. He researches Japanese war memories and "contents tourism" induced by works of popular culture. His books include Japan's Contested War Memories, Voices from the Shifting Russo-Japanese Border (co-edited with Svetlana Paichadze), Local History and War Memories in Japan, and Contents Tourism in Japan (with Takayoshi Yamamura, Akiko Sugawa-Shimada and Kyungjae Jang).

Ria Shibata is a Research Fellow at the National Centre for Peace and Conflict Studies, University of Otago in New Zealand, where she focuses on identity, collective memory, victimhood, and the role of apology in resolving seemingly intractable conflicts. Her doctoral thesis examined identity in relation to Japanese acceptance of collective guilt and responsibility for transgressions during the Second World War, and her publications have focused on the contribution of identity to prolonging conflicts in international relations.

Rebecca Suter is Associate Professor of Japanese Studies and Comparative Literature at the University of Sydney. She teaches and researches in modern and contemporary Japanese literature, comparative literature, and cultural studies, with a focus on cross-cultural representations and negotiations. She is the author of The Japanization of Modernity: Murakami Haruki between Japan and the United States (2008), Holy Ghosts: The Christian Century in Modern Japanese Fiction (2015), and co-editor of Rewriting History in Manga: Stories for the Nation (2016) and Women's Manga in Asia and Beyond (2019). Her most recent book, Two-World Literature: Kazuo Ishiguro's Early Novels, is forthcoming in 2020. 


\section{Acknowledgements}

This book emerges out of the international symposium "Popular Culture, War Memory and Reconciliation between South Korea and Japan", held at the University of Auckland, New Zealand in August 2017. The symposium received generous funding and logistical assistance from the Japan Studies Centre and Korea Studies Centre of the New Zealand Asia Institute, the University of Auckland. Our thanks go first and foremost to Mark Mullins, the Director of Japan Studies Centre, for the initial suggestion of the symposium and support throughout. Changzoo Song was instrumental in securing additional support from the University of Auckland's Core University Program for Korean Studies (Academy of Korean Studies AKS-2017-OLU-2250001). We express further gratitude to administrator of the New Zealand Asia Institute Dinah Towle, as well as Yoojin Choi and Florence Crick-Friesen, for their assistance in organisation and making the conference run smoothly. Alexander Bukh and Karl Chua brought their collegiality and insight to bear for fruitful discussions over the course of three days. We are also grateful to Mark Selden, the editor of the series Routledge Studies in Asia's Transformations, for his eternally lightning-quick, thoughtful and kind feedback and encouragement, and to Georgina Bishop and Stephanie Rogers at Routledge for their efficient guidance in helping to prepare the final manuscript. Above all, we thank our fellow contributors to this volume (with a special nod to Roald Maliangkay for his feedback on several chapters); their engagement and commitment to develop conversations between Japanese studies and Korean studies scholarship around the shared belief that popular culture matters have brought this book into being. 


\section{Notes on romanisation and names}

In this volume we use Revised Hepburn for Japanese (except where Traditional Hepburn has been employed as a part of a proper noun). We use a modified version of the McCune-Reischauer Romanisation system for Korean; we also include hyphens to show grammatical suffixes and transcribe sound changes if a final consonant appears intervocalically before the suffix. Korean and Japanese names appear in the order of family name followed by given name, except where individuals have published in English using the reverse form. Korean names present a further conundrum in that those that have become well known in English with alternative romanisations generally retain this spelling, and we adhere to this practice. Determining what is "well known" involves an obvious and difficult judgement call, but we have included major politicians and individuals from pop culture with international standing (e.g. Park Chung Hee, Bae Doona) in this category. 


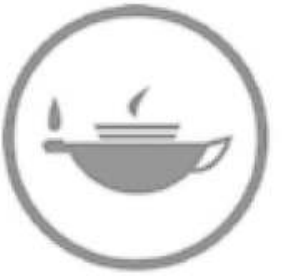

Taylor \& Francis Taylor \& Francis Group http://taylorandfrancis.com 


\title{
Introduction
}

\section{Popular culture and the transformation of Japan-Korea relations}

\author{
Rumi Sakamoto and Stephen Epstein
}

In 2017 an international group of Asian Studies researchers convened at the University of Auckland for a symposium on "Popular Culture, War Memory and Reconciliation between South Korea and Japan”. Each participant engaged in a topic that traverses the two countries and addressed such questions as: how have historical memories of Japanese-Korean interactions been consumed, contested, and reinscribed via popular culture? How do the contemporary Japanese and South Korean states use and manipulate culture at the mass level, and how does popular culture in turn support or challenge state ideology and patriotism? What consequences do developments in digital technology and the rise of social media hold for Japan-South Korea relations?

This volume, Popular Culture and the Transformation of Japan-Korea Relations, seeks to follow up on the symposium's fruitful discussions and to stimulate further dialogue between Japanese Studies and Korean Studies in exploring the impact of popular culture and indirect grassroots engagement between Japan and (South) Korea on possibilities for a deeper reconciliation. As the symposium's sessions highlighted, despite growing attention to transnational scholarship within Asian Studies, a single-nation focus remains common and reproduces the political and intellectual separation of the nation-states. The chapters presented here thus look to promote conversations and fresh insights between scholars of Korea and Japan on the ways in which the relationship between the two is mirrored in popular consciousness and practice. The volume draws on geographical, cultural, theoretical, and methodological diversity among its contributors as each links popular culture with Japan-Korea relations. In embedding their research in specific social, political, and temporal contexts, the authors present rich new empirical data for examining issues that have become ever more pressing in recent years.

\section{Popular culture and international relations}

How, indeed, does popular culture reflect and affect relationships between countries? The relevance of the question, with its attention to a realm dismissed not long ago by many as confined to entertainment, has become undeniable in today's globalised, mass consumer societies. Joseph Nye (1990) has famously 


\section{Rumi Sakamoto and Stephen Epstein}

drawn attention to the concept of soft power, which stimulated both academic and government interest in how popular culture may mould perceptions of a country, its values and ways of life. Sober analysis of state-to-state interaction by international relations specialists now regularly encompasses discussion of public diplomacy, and important studies treat popular culture as a site of meaning production, through which power is exercised, consent given or manufactured, and norms challenged (Grayson 2015; Caso and Hamilton 2015; Hamilton and Shepherd 2016). Scholars have examined the contribution of popular culture to shaping political identities based on notions of collective selves and Others (Cho 2009; Duncombe and Bleiker 2015), and how the affective capacities of popular culture bring appeal to nationalist sentiments (Feischmidt and Pulay 2017). Recent research has also furthered understanding of links between popular culture and security (Lene 2011; Rowley and Weldes 2012; Pears 2016), and popular culture's potential in helping to alleviate international conflict (Press-Barnathan 2017). Especially in democratic societies, where policy decisions occur amidst the scrutiny of public opinion, studying popular culture as a window into the electorate's lived experience of international relations has obvious merit, for cultural texts can reflect, and even influence, state-to-state affairs. ${ }^{1}$

Popular Culture and the Transformation of Japan-Korea Relations thus takes as a starting assumption the notion that relationships between countries involve multiple non-official channels and that consumption of popular culture impinges upon mass sentiment and can shape relations between countries, albeit in elusive, unpredictable, and often contradictory ways that render simple cause and effect relationships untenable. By "popular culture" we mean not only cultural texts distributed via mass communication networks, but also the everyday practices, public discourses and new digital media that give voice to grassroots sentiments at a broad level. Though far from unified and often challenging a mainstream, popular narratives and imagery embody a people's aspirations, desires, and fears. Discourses created and consumed in a given polity can engage with aspects of international "relations" treated at times as top-down and monolithic. They can push from the bottom-up at interstate contacts by producing ethnocentric images of foreign Others and concomitant structures of feeling that distinguish "Us" from "Them". These discourses can also, by contrast, encourage cosmopolitan attitudes and aspirations in the face of narrower state-led projects.

Elements of popular culture, consequently, can both serve hegemonic political interests and dominant ideologies, and oppose them. No matter which strategies texts, discourses, and practices point towards, they remain close to everyday experience at a broad level. Thus, consideration of popular culture helps explicate both macro- and micro-narratives and quotidian resistance. Moreover, cultural texts move across borders and accumulate meanings as they do so, sometimes subtly, sometimes more dramatically. The constant flux of popular sentiments and attitudes makes capturing a shifting and ephemeral zeitgeist notoriously difficult, and we certainly do not claim to offer here a comprehensive understanding of the interaction between popular culture and 
state-to-state relations. Rather, this volume hopes to contribute generally to illuminating popular culture, practice, and discourse as meta-phenomena that go beyond commodity and entertainment. More specifically, we seek to add nuance to the understanding of Japan-Korea relations, by examining the popular register over a long period and highlighting its dynamic, elastic contours.

Accordingly, this collection examines the diverse ways in which popular culture mirrors and generates ongoing changes in Japan-Korea relations, relations which were rendered even more turbulent by the division of Korea and the subsequent war that left the peninsula with two competing states. The volume extends the symposium's focus on South Korea's post-war relations with Japan geographically and temporally, as consideration of North Korea necessarily informs an understanding of relations between Korea and Japan writ large. Chapters by Markus Bell and Sunhee Koo testify to the importance of keeping North Korea present in discussions of how popular sentiment influences JapanKorea relations. Roald Maliangkay's contribution on timekeeping practices provides eloquent testimony to the subtle but far-reaching effects of changes in popular consciousness upon these relations from early in the colonial period.

For the most part, however, our authors focus on more recent interactions between Japan and South Korea specifically. The topic for this pair of countries acquires added significance because both have been among the most successful in propagating their popular culture internationally and are at the forefront of national branding projects. For over two decades, mass media and scholarship have shown great interest in the global spread of Japanese popular culture (e.g. Iwabuchi 2002; McGray 2002; Allen and Sakamoto 2006; Allison 2006; Tsutsui 2010) and the Korean Wave that followed closely on its heels (e.g. Kim 2013; Hong 2014; Kuwahara 2014; Lee and Nornes 2015; Marinescu 2016; Jin 2016; Yoon and Jin 2017). The practice of Hallyu and Cool Japan testify to state deployment of popular culture as a tool to extend its influence beyond national borders, stimulating popular nationalism (Iwabuchi 2007; Joo 2011), and the transnational flows of Japanese and Korean popular culture have emerged as a productive field for the study of cultural globalisation and Asian regionalisation (Black et al. 2010; Otmazgin 2014). While much recent discourse on the rise of Japan and South Korea as popular cultural superpowers has concentrated on such eye- (and ear-) catching entertainment media as manga, anime, and pop music, the volume takes a broader approach to include habitus and the lived experience of daily life as sites where relations between Japan and Korea are experienced and (re)produced.

\section{Japan-Korea relations in historical perspective}

In order, then, to contextualise the chapters' consideration of popular culture's impact on Japan-Korea relations, we now provide an overview of contact between the two, which reaches back several centuries. As is widely accepted, Korea served as an intermediary for the transmission of culture from the classical seat of East Asian civilisation in China to Japan. Important cultural 


\section{Rumi Sakamoto and Stephen Epstein}

phenomena, such as the spread of Buddhism and the adoption of written script, entered Japan via the Korean peninsula. Well-established trade and exchange networks, though punctuated by periods of conflict, most notably the invasions of the late sixteenth century led by Toyotomi Hideyoshi, remained in place for well over a millennium. A basic level of familiarity and mutual awareness between the peoples of Korea and Japan as neighbours across the water underpins developments that have continued until today.

The increasing encroachment of Western powers in the nineteenth century brought about fundamental shifts in the East Asian power balance. Meiji Japan modernised rapidly in response to the inroads of the West, and its own imperial ambitions rose to a crescendo in the occupation of Korea from 1910 to 1945. Japan's colonisation of Korea over this period ushered in new forms of modernity and economic changes that left an irrevocable mark upon Korea, and the benefits of development were accompanied by harsh forms of oppression. A large body of scholarship has looked at how Japan sought to assimilate Korea within its empire and bring Korean culture in line with its own (Shin and Robinson 1999; Dudden 2005; Yoo 2008; Caprio 2009; Henry 2014). Colonised Koreans were transformed into Japanese imperial subjects and attempts were made to reshape their identity via the imposition of Japanese names, languages and education. As Japan plunged into war, Korea became a source of labour for Japan's war effort, including sexual and military; the actual circumstances and levels of coercion involved remain a heated point of contention. This bitter colonial legacy casts a deep shadow that continues to darken the Korean peninsula's relations with Japan and not infrequently finds expression in popular culture.

Since Korea's liberation from Japan at the end of the Second World War, relations have experienced ongoing turmoil, characterised by cycles of greater and lesser strife. Although both Koreas share enmity towards Japan, significant differences exist between North and South Korea in how this antipathy is experienced and expressed. In this introduction we keep our attention on South Korea. A milestone in its relations took place in 1965, when Park Chung Hee pushed through diplomatic normalisation in defiance of popular opposition among his countrymen. Park, who was trained in the Japanese military and went on to serve as the president of Korea for 18 years, has often been regarded as a Japanophile and proved a contentious figure (Eckert 2016). The signing of the "Treaty on Basic Relations" purported to offer a roadmap for moving contact between South Korea and Japan forward in a positive direction; not long after, Japan recognised the Republic of Korea as the sole legitimate government on the Korean peninsula. Half a century later, the Treaty on Basic Relations continues to colour (and arguably derail) attempts to work towards fuller reconciliation; its clause that the $\$ 500$ million grants and loans Japan paid South Korea's military government "completely and finally" settled all claims between the two countries has provided the Japanese state with a rationale for avoiding reconsideration of its colonial and war responsibility. Conversely, because it was Park who brought the treaty into law, progressives in Korea have sought to deny its legitimacy and disputed the terms under which it handled compensation to individuals. 
The rapid growth of the South Korean economy during the 1970s and 1980s was accompanied by changes in its relations with Japan. Diplomatic tensions arose in 1982 over a history textbook published in Japan. Many more such disputes have arisen since in relation to how the education systems of each country choose to recall the past (Morris-Suzuki 2000; Nozaki 2008; Selden and Nozaki 2009). Prime Minister Nakasone's visit to Yasukuni Shrine in 1985 and the backlash it spurred in South Korea have also served as a template in a recurring area of conflict. With the end of South Korea's military dictatorship and its ongoing democratisation in the 1990s, rifts deepened between the two countries over issues of historical remembrance. The 1993 Kono statement, which acknowledged Japanese military involvement in the establishment and management of comfort stations, the 1994 establishment of the Asian Women's Fund to help compensate former comfort women, and the 1995 Murayama statement on the fiftieth anniversary of the end of the Second World War, which apologised for the suffering Japan had caused, all attracted criticism from Korea as insufficient attempts on the part of Japan to address its past.

In 1998, President Kim Dae Jung and Prime Minister Obuchi Keizō signed a Japan-South Korea Joint Declaration, which included a specific apology for Japan's colonial rule over Korea and heralded a "New Japan-South Korea Partnership towards the 21st Century". This declaration had important ramifications for popular culture, and from that year a longstanding ban on Japanese cultural imports in South Korea and public displays of Japanese culture began to be lifted in stages. Relations between the two countries witnessed positive developments at a broader level, most strikingly in the joint hosting of the 2002 FIFA World Cup. Two years later, the Korean TV drama Winter Sonata sparked unprecedented Japanese interest in the popular culture of its neighbour. The number of Japanese travellers to Korea grew, as did Japanese learners of the Korean language. The sharp rise in mutual consumption of popular culture suggested to many the possibility of a warmer relationship, and the two governments worked together to hold a Japan-Korea Friendship Year in 2005 on the fortieth anniversary of the establishment of diplomatic relations.

Nonetheless, even amidst these new forms of popular engagement, and as many individuals and institutions sought to bring about reconciliation, contention over a variety of issues has regularly threatened to undo gains. Even the spread of Korean popular culture and its enthusiastic reception among many in Japan, particularly women, precipitated a highly touted backlash of anti-Korean sentiment. A proliferation of scholarship (e.g. Shin et al. 2008; Kim and Schwartz 2010; Lewis 2017; Chin 2019) has highlighted the many areas in which Japan and South Korea have come into conflict: in 2001, controversy arose again over the publication of a history textbook in Japan that Koreans saw as whitewashing its past aggression, and Prime Minister Koizumi began his annual Yasukuni Shrine visits, prompting widespread anger and diplomatic strife. Resentment over the Liancourt Rocks also festers. The declaration of a Takeshima Day by Shimane Prefecture spawned a nationalistic surge in Korea at what was felt as a violent affront to the nation's sovereignty over Dokdo. 


\section{Rumi Sakamoto and Stephen Epstein}

The 2005 Japan-Korea Friendship Year proceeded under black clouds as a result of this territorial dispute. Animosities spiked once more in 2012, when President Lee Myung-bak visited the islets, leading to the recall of the Japanese ambassador to South Korea and cancellation of planned meetings. Japanese public opinion regarding South Korea plummeted.

Disputes over the comfort women have pushed the two nations into protracted battle. Although a landmark 2015 agreement between Park Geun-hye and Abe Shinzo on the comfort women purported to resolve the issue "finally and irrevocably", this final and irrevocable agreement was nullified only three years later by Park's successor, Moon Jae-in. Moon's confrontational action partly reflected a desire to differentiate himself from Park. Not only did Park leave office in disgrace upon being impeached, she was the daughter of Park Chung-hee and therefore seen as pro-Japanese. Even more fully, however, Moon's action drew upon popular discontent in Korea over the state-to-state nature of the 1965 normalisation, the 1998 Joint Declaration and 2015 agreement. Moon's administration also unilaterally decided to dismantle the Japan-funded foundation to support former comfort women that lay at the core of the pact, effectively rendering the agreement toothless. Korean collective determination to remember the comfort women's suffering has also led to the 2018 establishment of a Comfort Women Memorial Day and a museum dedicated to their memory set to open in 2020. Both of these steps have occasioned protest from conservative sectors in Japan. Amidst all this, a 2018 Korean Supreme Court decision that Japanese companies needed to compensate Korean plaintiffs for wartime forced labour led the Japanese government to retaliate by placing restrictions on exports to Korea and removing Korea from its list of countries that receive preferential treatment. Korea then countered with its own trade restrictions and came close to cancelling an intelligence-sharing agreement. Although President Moon has promoted "two-track diplomacy" that distinguishes economic and political ties with Japan, this approach has waned. While globalisation can encourage bilateral ties and regional integration, in 2019 conflict between Japan and Korea boiled into a fervid dispute that put the ongoing volatility of relations on highly visible international display.

\section{Close but distant neighbours}

What does all the above mean for our volume? Examination of the popular is particularly relevant to Japan-Korea relations, where state initiatives to "resolve" historical issues like the 2015 comfort women agreement and the earlier Asian Women's Fund have failed as they were met with popular resistance and criticism. State will, on its own, is clearly insufficient for resolution and reconciliation. Traditional notions of international relations may well hold that truly crucial matters occur at the state-to-state level, but relations between nationstates entail far more than diplomatic contacts. Official declarations and agreements have failed to bring closure to historical concerns because they neither involved the victims themselves nor delivered what Koreans at a broad level 
consider a sufficient apology over colonisation. Resentment over colonisation remains deeply rooted in Korea, and the Japanese government's expressions of remorse over past actions have long been perceived as insincere. As a result, tension between Japan and Korea has shown little sign of abating.

Nevertheless, despite what can seem like an intractable conflict, Japan-Korea relations have neither always been homogeneously antagonistic nor had a clear trajectory, and we should not assume that they have always been and always will be problematic. Even at zeniths of tension, popular connections continue. Japanese public opinion may have become more negative towards Korea over the course of the 2010s, even as anti-Japanese sentiment continues as a primary factor in shaping South Korean identity and nationalism. A 2019 Japan-Korea public opinion survey jointly conducted by Genron NPO and the East Asia Institute, think tanks from each respective country, has also shown the worst result in decades, with only 20 per cent of Japanese respondents indicating a favourable impression of Korea, ${ }^{2}$ and Korean boycotts of Japanese products such as beer and the clothing store Uniqlo hit hard (Handley 2019). However, the annual Japan-Korea festival that started during the 2005 Japan-Korea Friendship year still went ahead in 2019 in each nation's capital. More strikingly, Tokyo's Hallyu convention KCON JAPAN attracted 88,000 visitors in 2019, the highest attendance since it began in 2015 and a 30 per cent increase from the previous year. Although but small examples, they demonstrate the need to exercise caution in positing linear trends that show general regression (or progress) in Japan-Korea relations at any given moment.

Indeed, after more than a year of communication breakdowns over the forced labour issues, Abe and Moon managed to meet in late 2019 to address the simmering national dispute. Their expressions of desire to solve bilateral issues through dialogue undoubtedly pay partial lip service to diplomacy, but the two countries face common challenges, and the tug of nationalistic impulses will not completely obscure the benefits of trade and security cooperation for the two leaders. In contemporary democratic mass societies like Japan and South Korea, political will cannot proceed without popular support. State-to-state tension affects mutual national perceptions, but popular sentiment equally impinges on state-to-state relations and has had tremendous influence in Japan and Korea in recent years.

As tensions over historical memory and territorial disputes between the two cultural superpowers in East Asia continue in conjunction with the mutual and international consumption of their popular culture, this volume therefore brings these key areas of interest together. In shifting our focus from formal state-level interaction to popular culture, we hope to illuminate the latter's impact on relations between Japan and Korea and to offer a long-ranging view that captures this uneven, "one step forward, two steps back" movement of Japan-Korea relations. Popular culture functions as an index to a nation's collective outlook, and it can also, albeit in a loose and dispersed fashion, promote or impede nationalisms, conflict or reconciliation outside state authority. Contributions to this volume illuminate these processes in several ways: by analysing popular culture 


\section{Rumi Sakamoto and Stephen Epstein}

in multiple contexts - colonial, postcolonial, national, and transnational (Maliangkay, Perkins, Koo, Choo); by treating popular culture's ability to affect perceptions and create joint, alternative, or contested perspectives and sentiments (Bell, Lee, Sakamoto); by examining the role of popular culture in promoting or challenging nationalistic discourse (Seaton, Choi, Shibata); and by seeing audiences as agents shaping views on history, national identity, and images of the Other (Suter, Epstein).

\section{Chapter outlines}

The chapters' case studies, then, highlight how popular culture has created spaces within which Japan-Korea relations are conceived, negotiated and transformed, and examines ways in which Japan-Korea relations are addressed in popular culture, ranging from the grossly simplistic to the thoughtfully nuanced. The volume spans many decades, during which Japan-Korea relations experienced significant change, from the colonial period through the division of North and South Korea, South Korea-Japan normalisation, the rise of Japan and South Korea as global economic powers, the United States' post-9/11 pivot to Asia, and the shift in the Asian regional order with China's rise. Individually the chapters examine images of and beliefs in Japan and South Korea about each other, understandings of the past and future relations, and the possibility of imagining these relations differently. They illustrate how the visual, visceral, and emotional media of popular culture depict bilateral relations and symbolic nationhood, and how the mutual reception and understanding of popular cultural texts are shaped by the intersection of memories of a colonial past and contemporary relations. Taken together, they testify to the complex ways in which Japan-Korea relations are seen, experienced, and contested through everyday practices, media, and culture.

We have divided the book into four parts of three chapters each. The first two - "Transforming Japan-Korea Relations in Everyday Practice" and "Reimagining Japan-Korea Relations in Film" - take two key facets of popular culture, daily habitus and the crucial medium of cinema, for in-depth explorations of how these contrasting areas of lived experience and imagined creations each have responded to and influenced Japan-Korea relations. Part III, "Japan-Korea Relations and Popular Culture Manipulations", puts the spotlight on how diverse phenomena and artefacts - an idea, a life, a product, a place - can become objects of popular discourse that lend themselves to manipulation by different publics and cultural producers to respond to different needs. Part IV, "JapanKorea Relations and Popular Culture Engagement", provides a parallel focus on reception and how audiences of popular culture themselves respond to what they consume and in turn cause ongoing transformations in how popular culture affects society. To round off this introduction we provide a more detailed overview of each part's and each chapter's contribution.

Part I, "Transforming Japan-Korea Relations in Everyday Practice", addresses how Japan-Korea relations are interwoven and transformed on a 
quotidian basis. Its chapters illustrate how aspects of Japan-Korea relations are lived in everyday engagement, by examining such topics as a new sense of temporality introduced by the colonial power, a popular historical novel/drama that spurred tourism, and exchanges of letters, food, and material goods between families in Japan and North Korea. This first trio of chapters reminds us of the multifarious nature of engagement with, and experience of, Japan-Korea relations, and advances our inquiry beyond consumption into the elusive but visceral realm of affect.

In "Colonial Timekeeping: Bringing Koreans up to speed", Roald Maliangkay presents a detailed analysis of the introduction of modern time-keeping in colonised Korea, demonstrating how changes in seemingly mundane practices shaped Koreans into colonial subjects. The Japanese colonisers' initial portrayal of Koreans as lacking in work ethic served to justify intervention, even as the image attracted Japanese anthropologists and tourists. In order to serve the Japanese empire, the colony had to be reorganised and brought up to "speed". The Western calendar and its time-keeping standards represented modernity and development, and their introduction became a priority for the colonial administration. Maliangkay analyses not only the lasting impact the introduction of these standards had on Korean daily life, but also its meaning for relations between Korea and Japan. His inventive approach examines how the promotion of timemeasurement regimens and punctuality among Japan's colonial subjects encouraged integration of Koreans in the empire's operations. He also asks further intriguing questions: how did the new calendar and time-measurement devices affect popular culture? Which aspects of these regimens did Koreans resist, and why?

Markus Bell takes a similarly novel approach in considering the informal exchanges that took place between post-war return migrants to North Korea and their families in Japan, despite the absence of official diplomatic relations between the two countries. Drawing on unusual archival data from the Red Cross that includes letters between separated family members, Bell demonstrates the extent of engagement amidst Cold War politics. Through sympathetic readings and close analysis of messages that travelled across the water between Japan and North Korea in the 1960s and 1970s, he brings to life an intimate and littleknown area of transnational contact and charts the changing significance of items that moved back and forth. Bell also shows how such informal and often gendered correspondences of divided families led to the "life politics" of a movement to "rescue" Japanese wives who went to North Korea with Korean husbands, as well as lobbying of the Japanese government and challenging North Korea's abuse of its citizens. The chapter vividly brings to life a transnational imagined community and its multiple modes of belonging.

Philip Seaton offers a very different view of how the popular intertwines with the political in "The 'Shiba view of history' and Japan-Korea Relations: Reading, watching and traveling Clouds Above the Hill'. In this chapter, Seaton challenges interpretations of history promoted by Shiba Ryōtarō, one of Japan's most read novelists. Shiba's works, which have sold millions of copies and been 
adapted for television, present the Meiji period in positive contrast to the years between 1905 and 1945, when Japan made "mistakes" and made a dark descent into imperialism and war. Such a view, however, runs against that held by most Koreans and threatens possibilities for finding shared understandings of history. Nonetheless, Shiba's views continue to carry weight among not only Japan's conservative political elites, including current Prime Minister Abe, but also the general public. Seaton argues that because Japanese control over the Korean peninsula moved from vision to reality during the Meiji period, Shiba's favourable reception in Japan has an ongoing negative impact on Japan-Korea relations and future prospect of reconciliation, and all the more so because Shiba's popularity has meant that his views have been incorporated into tourist sites developed on the basis of the novel and subsequent drama.

Part II, "Reimagining Japan-Korea Relations in Film", consists of case studies that examine how Japanese and Korean popular cinema intersect with colonial and war memory. As often pointed out, film can afford a crucial site of collective memory and national identity formation. The immersive nature of a medium that, in the hands of skilled filmmakers, yokes vivid images to compelling narratives creates a powerful vehicle for reinforcing a sense of shared identity and instilling cultural memory across generations. The Japanese colonial period has been a popular subject of recent South Korean cinema; in "Remembering to Reset: Representation of the colonial era in recent Korean films", Heeseung Irene Lee narrows her focus to the films of 2015 and 2016 and argues that these texts demand from their audiences a refreshed understanding of Korean suffering under colonial rule. Lee points out that, in contrast to the less successful works of the previous decade that invoked colonised Korea as familiar backdrop, these more recent cinematic images challenge prevailing memories of the colonial experience and its legacy and, in doing so, have aroused domestic interest by providing diverse narratives, characters, and perspectives. Lee focuses on two films that feature resistance fighters pushed to a precarious border between patriotism and betrayal, Assassination (Amsal, 2015), which sold over 10 million tickets, and The Age of Shadows (Milchŏng, 2016). She persuasively argues that these recent productions redefine the colonial era as a turbulent grey zone that foisted dilemmas upon Koreans and provides a tentative explanation for why these films surfaced in the mid-2010s during Park Geun-hye's presidency.

As is well known, towards the end of the Pacific War, several thousand young men lost their lives in kamikaze suicide attacks; less known, however, is that at least 17 were Korean. Rumi Sakamoto looks at cinematic examples of Korean kamikaze pilots in the Japanese films, Firefly (Hotaru, 2001) and I Will Go to Die for You (Ore wa kimi no tame ni koso shini ni iku, 2007). By analysing the representations of colonised subjects on suicide missions for the Japanese empire, she examines whether the films' inclusion of Koreans confronts nationcentred images of kamikaze as Japan's tragic heroes. Although both base their Korean characters on the same real-life figure and refrain from naturalising a Korean pilot into an archetypally Japanese tragic figure, the Korean Other 
functions differently in the two films. Sakamoto's detailed textual analysis demonstrates how I Will Go to Die for You provides an aestheticised narrative of sacrifice that ultimately reabsorbs Otherness into the story of the nation. Conversely, she argues, Firefly resists treating kamikaze pilots as pure national heroes or victims; in her reading, the film's more nuanced representations create spaces for cultural memory that coalesce not around nationalist narratives but desire for reconciliation.

Kukhee Choo's "Memories of Comfort: Postcolonial production and consumption of Koreeda Hirokazu's Air Doll" examines an idiosyncratic Japanese film about an inflated sex doll that develops a soul. Although the multinational team that came together for Air Doll (Küki ningyō, 2009) places the film among the transnational co-productions among East Asian countries that have burgeoned since the 1990s, by venturing outside the region like other recent works, Koreeda's film experiences a complex interplay of local producers and global consumers and raises questions about the relationship between national identity and international spectatorship. In particular, Choo questions how the casting of Korean actress Bae Doona as the title character of Air Doll affects interpretation of the film in light of its adaptation from an existing manga text and the historical relationship between Japan and Korea. Choo thus analyses the complexity of the film's relationship to postcolonial socio-historical deconstructions of wartime memories, especially given the potential associations of the protagonist and comfort women. In doing so, she highlights the challenge that Air Doll presents to notions of trans-Asian cinema in an era of borderless film production.

The three chapters of Part III, "Japan-Korea Relations and Popular Culture Manipulations", examine how cultural artefacts can readily move across national borders, accumulating new meanings as they do so. Such inflections of signification can be subtle or unexpected but inevitably respond to the specific historical circumstances in which they are embedded. Chris Perkins' chapter, for example, argues that considering Japan's media treatment of Korea in historical perspective sheds light on possibilities of reconciliation between the two. His case study of New Wave director Oshima Nagisa's 1965 documentary Yunbogi's Diary (Yunbogi no nikki) illuminates how audiovisual media's representations establish aesthetic frameworks for engagement between nations and thereby influence relations between them. His analysis of the documentary's aesthetic and affective strategies shows how the film negotiates Japanese feelings of guilt towards its former colony. The documentary, which appeared shortly after the normalisation of relations between Japan and South Korea, is based on a bestselling diary of a young boy struggling to survive on the streets of a city in Korea. Perkins situates both works within the context of 1960s Japan and traces the discourse produced by each, and discusses how, counterintuitively, the book and film became integrated into Japan's own narratives of victimhood, as Yunbogi's story came to represent what Japan had lost in the post-war period.

How does the popular culture of the region engage with the division of the Korean peninsula, the presence of North Korea, and its triangulated relationship with Japan and South Korea? In “'Imjin River' and the Transnational 


\section{Rumi Sakamoto and Stephen Epstein}

Consumption of Partitioned Korea", Sunhee Koo makes a compelling journey along the byways of "Imjin River" (Imjin'gang), a North Korean song composed in 1957. The song's lyrics and imagery evoke the Imjin River that flows southward, traversing the demilitarised zone and joining the Han River near Seoul. The song's depiction of the river captures the sentiments of not only North Koreans who long for their lost homeland in South Korea, but members of the divided nation below the 38th Parallel who yearn for loved ones to the north. Although introduced in Japan through Zainichi schools affiliated with North Korea, its wide local circulation depended in large part on the Folk Crusaders, a Japanese band popular in the 1960s. Koo illustrates how "Imjin River" has registered in multiple contexts as it has travelled, crossing ethnic, national, and generic boundaries. The ability of this North Korean song to epitomise a communist ethos, to express nostalgic desire for pan-Korean identity, and to serve as a protest vehicle for 1960s Japanese university students offer striking testimony to the malleability of popular culture texts between Korea and Japan. She concludes that the partition of the Korean peninsula renders the song a device for experiencing diverse emotions that render it meaningful for a variety of audiences.

Yoojin Choi presents an intriguing case study of transnational image production and consumption in her discussion of how the Japanese island Gunkanjima (Gunhamdo in Korean) has become a new site of public memory contestation. The chapter also underscores how conflict between Japan and Korea increasingly finds itself intertwining within global institutions: the nomination of Gunkanjima as a UNESCO World Heritage site by Japan in 2015 sharpened the focus on the island as a contested site of memory. Through an insightful close reading of TV entertainment shows in Japan and South Korea, Choi reveals how the island quickly came to symbolise both the Meiji era's glorious "industrial miracle" in Japan and an "island of hell" for Koreans, where forced labour conscription took countrymen to work under inhumane conditions during the Asia-Pacific War. Popular media have drawn upon Gunkanjima as a productive site for the creation and dissemination of images that reinforce contradictory interpretive frameworks. Choi cogently demonstrates not only the obvious discursive oppositions but, importantly, the underlying structural similarities that reveal equivalent nationalisms.

Part IV, "Japan-Korea Relations and Popular Culture Engagement”, shifts the focus to the role of audiences who, as consumers of nation-centred imageries of victimhood or as prosumers reinscribing the nation in their own discourse, interact with text. In 'Lovers' Quarrels: Japan-Korea relations in Boys' Love manga", Rebecca Suter addresses the web manga Axis Powers Hetalia, a popular series of comedy short strips set during the First and Second World Wars, in which the Axis powers, Allied countries, and other nations are personified as bishonen (pretty boys). Suter examines the complex reception of the Japanese webcomic's image of Korea, which is inspired by the confluence of national stereotypes and the subcultural "Boy Love" trope. When the production of an animated version was announced in Japan, however, South Korean readers petitioned their National Assembly to request the Japanese producer to cancel its 
broadcast, arguing that the portrayal of "Korea" amounted to criminal discrimination. Though unsuccessful, the petition received much attention online. Suter also analyses the relationship between the personified "Korea" and "Japan" in the original and its parody offshoots created by predominantly female fans, many based outside of East Asia, around romantic pairings between these bishonen nations. The varying relationships that fans have to the nations and the contexts in which they write imbue their work with differing meanings. Suter thus uses the genre of Boys' Love to reflect on the production and consumption of national stereotypes and their impact on Japan-Korea relations, urging a nuanced understanding of the role of popular culture in international politics.

"Fly the Flag (At Your Own Risk): Netizens, nationalism and celebrities between South Korea, Japan and beyond" by Stephen Epstein takes as a starting point the widespread condemnation experienced by Tiffany of K-pop icons Girls' Generation for captioning a Snapchat photo with a filter that recalled Japan's Rising Sun Flag. Epstein explores several incidents in which South Korean celebrities were attacked online for their seemingly insufficient patriotism in order to underline how nationalism intersects with the process of increasing mediatisation, personalisation and commodification of celebrity as well as media consumption, democratised fan production and the evolving relations between fans and celebrities. In particular, Epstein interrogates why celebrities are experiencing such panoptic policing by fan communities and being invested with increasing values as vessels of national sentiment, and asks what meaning this growing tendency holds for Japanese-South Korean relations. His chapter raises the larger questions of what developments in information and communication technology portend for how audiences experience popular culture and the meanings these hold for individuals and society.

Finally, Ria Shibata's contribution, “Japan's Inherited Responsibility, Popular Narratives and Memory of the War", also grapples with the question of what popular culture means for individuals and for society as a whole. Shibata works from the assumption that protracted conflicts often have roots in traumatic memories of violence and that acknowledgement of inherited responsibility is critical for reconciliation. Noting the extent to which Japan communally engages in historical amnesia by downplaying the Japanese Imperial Army's atrocities, she uses surveys and interviews to examine how current generations of Japanese "remember" the war through popular culture. She seeks particularly to unravel the connection between textual consumption and shaping of attitudes as she considers how exposure to Barefoot Gen (Hadashi no Gen) and Grave of the Fireflies (Hotaru no haka), two widely consumed texts that focus on domestic suffering, has affected how war is remembered by young Japanese. She also attempts to uncover factors that account for differences in reception among viewers. Her chapter thus explores how popular culture can shape acceptance by younger Japanese of responsibility for historical injustices and potentially open - or foreclose - spaces of reconciliation. Through this study, a fitting conclusion to the volume, Shibata aims to offer insight into how traumatic colonial past and longstanding grievances can be addressed effectively. 


\section{Rumi Sakamoto and Stephen Epstein}

Lastly, we wish to note that, given relations between the two countries, even the order in which we present them in the title may occasion grumbling, especially in light of a longstanding claim that after annexation of Korea, Japan worked to ensure that Korea's English spelling would be standardised away from Corea so that Japan would come before it in Roman alphabetical order (Demick 2003). Although we have ultimately been guided by precisely that alphabetical choice, and have preferred consistency over regularly switching the order, our procedure in no way implies the primacy of one member of the pair. It may be worth noting, too, as a final indicator of the impact of popular culture upon international relations, that one would have to look hard now to find even recidivist South Koreans who would seek to change the spelling back to Corea. The arrival of "Special K" - the force of the letter K as a powerful symbol for Korea via K-pop, K-dramas and the like - suggests that Korea with a $\mathrm{K}$ is here to stay.

\section{Notes}

1 See further Kiesey (2016) for a useful detailed bibliography of work that connects popular culture and international relations.

2 www.eai.or. $\mathrm{kr} / \mathrm{main} /$ english $/$ program_view.asp? intSeq=10213\&code=54\&gubun= program.

\section{References}

Allen, Matthew and Rumi Sakamoto. 2006. Popular Culture, Globalization and Japan. New York and London: Routledge.

Allison, Anne. 2006. Millennial Monsters: Japanese toys and the global imagination. Berkeley, Los Angeles and London: University of California Press.

Black, Daniel, Stephen Epstein and Alison Tokita (eds). 2010. Complicated Currents: Media flows, soft power, and East Asia. Melbourne: Monash University Press.

Caprio, Mark. 2009. Japanese Assimilation Policies in Colonial Korea, 1910-1945. Seattle: University of Washington Press.

Caso, Federica and Caitlin Hamilton (eds). 2015. Popular Culture and World Politics: Theories, methods, pedagogies. Bristol: E-International Relations. www.e-ir.info/wpcontent/uploads/2015/04/Pop-Culture-and-World-Politics-E-IR.pdf.

Chin, Leo. 2019. Anti-Japan. Durham, NC: Duke University Press.

Cho, Young Chul. 2009. "Security, Nationalism and Popular Culture: Screening South Korea's uneasy identity in the early 2000s". East Asia, 26: 227-246.

Demick, Barbara. 2003. "A 'C' Change in Spelling Sought for the Koreas". Los Angeles Times, 15 September. www.latimes.com/archives/la-xpm-2003-sep-15-fg-corea15-story. html.

Dudden, Alexis. 2005. Japan's Colonization of Korea: Discourse and power. Honolulu: University of Hawai'i Press.

Duncombe, Constance and Roland Bleiker. 2015. "Popular Culture and Political Identity". E-International Relations. 2 May. www.e-ir.info/2015/05/02/popular-culture-andpolitical-identity/.

Eckert, Carter. 2016. Park Chung Hee and Modern Korea: The roots of militarism 1866-1945. Cambridge, MA: Harvard University Press. 
Feischmidt, Margit and Gergo Pulay. “'Rocking the Nation': The popular culture of neonationalism". Nations and Nationalism, 23 (2): 309-326.

Grayson, Kyle. 2015. "The Rise of Popular Culture in IR: Three issues". E-International Relations. 30 January. www.e-ir.info/2015/01/30/the-rise-of-popular-culture-in-ir-threeissues/.

Hamilton, Caitlin and Laura J. Shepherd. 2016. Understanding Popular Culture and World Politics in the Digital Age. New York and London: Routledge.

Handley, Erin. 2019. "South Koreans Are Rejecting Japanese Beer and Cars - Here's Why". ABC News, 29 October. www.abc.net.au/news/2019-10-27/why-you-mightstruggle-to-buy-japanese-beer-in-south-korea/11603138.

Henry, Todd. 2014. Assimilating Seoul: Japanese rule and the politics of public space in colonial Korea, 1910-1945. Berkeley, Los Angeles and London: University of California Press.

Hong, Euny. 2014. Birth of Korean Cool: How one nation is conquering the world through popular culture. New York: Picador.

Iwabuchi, Koichi. 2002. Recentering Globalization: Popular culture and Japanese transnationalism. Durham, NC: Duke University Press.

Iwabuchi, Koichi. 2007. "'Soft' Nationalism and Narcissism: Japanese popular culture goes global". Asian Studies Review, 26 (4): 447-469.

Jin, Dal Young. 2016. New Korean Wave: Transnational cultural power in the age of social media. Urbana, Chicago: University of Illinois Press.

Joo, Jeongsuk. 2011. "Transnationalism of Korean Popular Culture and the Rise of 'Pop Nationalism' in Korea". The Journal of Popular Culture, 44 (3): 489-504.

Kiesey, Nicholas. 2016. "Popular Culture and International Relations". Oxford Bibliographies. www.oxfordbibliographies.com/view/document/obo-9780199743292/ obo-9780199743292-0190.xml.

Kim, Mikyoung and Barry Schwartz (eds). 2010. Northeast Asia's Difficult Past: Essays in collective memory. London: Palgrave Macmillan.

Kim, Youna. 2013. The Korean Wave. New York and London: Routledge.

Kuwahara, Yasue (ed.). 2014. The Korean Wave: Korean popular culture in global context. New York: Palgrave Macmillan.

Lee, Sangjoon and Abe Nornes. 2015. Hallyu 2.0: The Korean wave in the age of social media. Ann Arbor, MI: University of Michigan Press.

Lene, Hansen. 2011. "Theorizing the Image of Security Studies: Visual securitization and the Muhammad cartoon crisis". European Journal of International Relations, 17 (1): $51-74$.

Lewis, Michael. 2017. "History Wars" and Reconciliation in Japan and Korea: The roles of historians, artists and activists. New York: Palgrave Macmillan.

Marinescu, Valentina. 2016. The Global Impact of South Korean Popular Culture. Lanham and London: Lexington Books.

McGray, Douglas. 2002. “Japan's Gross National Cool”. Foreign Policy, 130 (May/June): 44-54.

Morris-Suzuki, Tessa. 2000. "The View through the Skylight: Nishio Kanji, textbook reform and the history of the world". Japanese Studies, 20 (2): 133-139.

Nozaki, Yoshiko. 2008. War Memory, Nationalism and Education in Post-war Japan, 1945-2007: The Japanese history textbook controversy and Ienaga Saburo's court challenges. New York and London: Routledge.

Nye, Joseph. 1990. Bound to Lead: The changing nature of American power. New York: Basic Books. 


\section{Rumi Sakamoto and Stephen Epstein}

Otmazgin, Nissim. 2014. Regionalizing Culture: The political economy of Japanese popular culture in Asia. Honolulu: University of Hawai'i Press.

Pears, Louise. 2016. "Ask the Audience: Television, security and Homeland". Critical Studies on Terrorism, 9 (1): 76-96.

Press-Barnathan, Galia. 2017. "Thinking about the Role of Popular Culture in International Conflicts". International Studies Review, 19 (2): 166-184.

Rowley, Christina and Jutta Weldes. 2012. "The Evolution of International Security Studies and the Everyday: Suggestions from the Buffyverse". Security Dialogue, 43 (6): 513-530.

Selden, Mark and Yoshiko Nozaki. 2009. "Japanese Textbook Controversies, Nationalism, and Historical Memory: Intra- and inter-national conflicts". The Asia-Pacific Journal: Japan Focus, 7 (24.5). apjjf.org/-Mark-Selden/3173/article.html.

Shin, Gi-Wook, Soon-Won Park and Daqing Yang. 2008. Rethinking Historical Injustice and Reconciliation in Northeast Asia: The Korean experience. New York and London: Routledge.

Shin, Gi-Wook and Michael Robinson (eds). 1999. Colonial Modernity in Korea. Cambridge, MA: Harvard University Asia Centre.

Tsutsui, William. 2010. Japanese Popular Culture and Globalisation. Ann Arbor, MI: Association for Asian Studies.

Yoo, Theodore Jun. 2008. The Politics of Gender in Colonial Korea: Education, labor and health, 1910-1945. Berkeley, Los Angeles and London: University of California Press.

Yoon, Tae-Jin and Dal Young Jin (eds). 2017. The Korean Wave: Evolution, fandom, and transnationality. Lanham, MD: Lexington Books. 


\section{Part I}

\section{Transforming Japan-Korea relations in everyday practice}




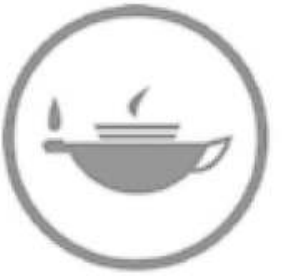

Taylor \& Francis Taylor \& Francis Group http://taylorandfrancis.com 


\title{
1 Colonial timekeeping \\ Bringing Koreans up to speed
}

\author{
Roald Maliangkay
}

The phrase "ppalli ppalli" (hurry, hurry) is sometimes used by Japanese to refer to the Korean approach to business, in both a positive ${ }^{1}$ and negative sense. ${ }^{2}$ As the phrase signifies the pursuit of results, regardless of magnitude or risk, Koreans often apply it critically themselves (see Kang 2010: 60-61; K. Kim 2008: 29). First promoted in the 1960s and 1970s, under Park Chung-hee's military administration (1963-79), this "quintessentially un-Confucian and nonagrarian military ideal" (Lie 2015: 79) has become a common phrase in South Korean organisational life. It was propelled by another of Park's mottos, "hamyŏn toenda" (If we try we can do it), ${ }^{3}$ which in 1983 inspired the SsangYong Motor Company, originally specialised in the assembly of military vehicles, to rebrand its compact SUV range as Korando, a contraction of "Korea can do". During his years of service in the Japanese imperial army in Manchukuo, Park adopted the principles that became fundamental to the success of his developmental state. Indeed, according to sociologist Han Sŏkchŏng, Park's approach towards economic and technological development in the 1960s was analogous to that which the Japanese applied in Manchukuo in the 1930s (Kim S. 2016). But in Korea, at least, the notions of punctuality and timeliness, so crucial to its conception, were ushered in earlier, from the late nineteenth century onwards.

It was common among Europeans to find the non-Western Other, including the Japanese, to lag in terms of development (Van Schendel and Schulte Nordholt 2001: 11; Hashimoto 2008: 124). ${ }^{4}$ Although it comprised a range of different standards in the early stages, Europeans saw their system of timekeeping as more practical and more productive than non-Western ones. Colonisers long persisted in bringing attention to cultural differences related to time management, often equating their colonial subjects with backwardness, immorality, and tradition, but the new time order would eventually be adopted around the world along with the Western calendar (see Nanni 2012: xi). In order to support the fast-increasing internationalisation of trade and communication, 26 nations adopted a resolution in October 1884 that established a global time order. Based on time kept by accurate clocks in London, this new standard was named after the astronomical observatory in Greenwich that had long been dedicated to the measurement of time (Goudsblom 2001: 30; Nanni 2012: 2). By improving the 
logistics of trade and communication, standardisation increased productivity and profit; it was a condition for effective administration and exploitation.

Time discipline existed in Japan well before industrial capitalism made inroads there, ${ }^{5}$ but the actors behind the Meiji Restoration of 1868 sought to place Japan on par with Western powers, militarily, technologically, and industrially. An Imperial Edict in 1872 reset the national calendar, and by 1888 Japan succeeded in making all its railroads and telegraph services follow a standardised time, years before major European nations managed to do so (Uchida 2002: 178-179; Kern 1983: 12). For the newly time-conscious Japanese government, Korea provided a contrast: around when they annexed Korea, Japanese news sources frequently reported on the Koreans' tardiness. In Korea, the introduction of a new order of time served the empire on political, ideological, and practical levels. The new regimen emphasised that Koreans were now part of a modern empire that was driving innovation and left no place for the inefficiencies of old. Like other colonial powers and the Christian mission, the Japanese justified intervention by portraying natives as lacking a sense of purpose, diligence, and an interest in progress (see Said 1979: 178, 253). The Japanese GovernmentGeneral reorganised and upgraded the colony's administration, infrastructure, and corporate sector to improve productivity and maximise profits. While it maintained the system of Japanese era names, it also implemented the recently adopted Gregorian calendar and other Western timekeeping standards considered critical for economic development. The introduction of these standards became a priority for the colonial administration and the public and private institutions that relied on time measurement, punctuality, and the use and consumption of clocks and watches. The lasting impact Western timekeeping standards had on Koreans' daily lives and aspirations yield crucial perspectives regarding the experience of colonialism and capitalism. By analysing the introduction of new time regimes in colonial Korea, this chapter seeks to answer the following questions: how did the Japanese promote the use of timetables and punctuality among their Korean colonial subjects? Which aspects of these changes did the Koreans resist, and why? And most importantly, in the context of this volume, how did the adoption of these practices transform relations between Japanese and Koreans?

\section{New standards}

Despite the pressure to adopt Qing culture and associated styles of administration following the Manchu invasion in 1636, for decades Korean officials rather spitefully persisted in following a system of time measurement adapted from the Datong-li calendar of the earlier Ming dynasty. After the Kanghwa Treaty of 1876, however, the Japanese began to exert pressure on Korea to modernise. ${ }^{6}$ After two decades, the Korean government adopted the Western Gregorian calendar (Shin 2017a: 185). On 1 January 1896, King Kojong had the dating in official documents changed from the lunar calendar to the solar calendar, which effectively erased some 45 days (Yi 2008: 144). Between 1896 and 1908, both the Western calendar and the myongshiryŏk, which combined solar-lunar 
calculations, were officially in use until the latter was abandoned in 1908 (Ch'oe 2008: 15). On the first of April that year, Korea adopted global time, and positioned itself 30 minutes behind Japan, and 30 minutes ahead of China (Oh 2008: 177). Soon after Korea's annexation in 1910, when the Japanese GovernmentGeneral distributed the Chosŏn minnyŏk (Korean people's calendar), annual dates were tied to the reign of a Japanese emperor, Meiji. In order to standardise time systems, in January 1912 the Japanese Government-General set Tokyo's time zone as the mean standard for Korea and ordered the replacement of Korean holidays with Japanese ones (Ch'oe 2008: 14-15).

As in Japan, the railway system played a significant role in ushering in the nationwide adoption of time zones and the importance of punctuality. Prior to the inclusion of Korea in the Japanese time zone, the latter was applied selectively to Seoul-Pusan and Seoul-Ǔiju train lines (Oh 2008: 177). Beginning in the late 1890s, periodicals included timetables for travellers (Ch'oe 2008: 18). Rail travel was a luxury exclusive to a minority of the population, but for the service to run punctually, passengers needed to board on time. As in the West, in Korea many watch manufacturers aimed at associating themselves with the accuracy that punctual railroad operations required. For example, an ad for Dolmy in 1927 shows a train crossing a bridge, another in 1929 promotes a special train watch, and one for Longines in 1934 shows a conductor with a pocket watch for a head. All these ads demonstrate an ongoing association between trains and punctuality (Chōsen Shimbun, 28 April 1927: 1; Tonga Ilbo, 24 December 1929: 7; Chosŏn Ilbo, 16 August 1934: 2).

Schools and businesses began to insist on punctuality as well, ${ }^{7}$ introducing one-hour classes and shifts, respectively (Lee 1988: 34; Park 1999: 90-93). Because few students and workers had watches, bells, sirens and wall clocks reminded them of the time instead. To boost productivity, factories introduced punch clocks and strict penalties for violations of punctuality (Park 1999: 90-91; Ch'oe 2008: 18-19). To educate people about the new time regimen, in 1888 a clock tower had been erected next to Kwanmun'gak library on the grounds of Kyŏngbok Palace. Clock towers in general public space appeared from the start of the twentieth century with one placed atop the Seoul Electric Company (Hansŏng chŏn'gi hoesa) building across from the Poshin'gak bell pavilion (Chŏn 2008: 233, 235) in 1902. ${ }^{8}$ The increasing prevalence of clocks and timetables in public promoted Western notions of timeliness even among those who did not need to pay attention to the latter for their livelihood or education, or who had already completed their daily tasks. Indeed, in October 1932, a new three-face clock tower was revealed at Seoul Stadium whose nine-metre height was tall enough to allow those watching athletics or baseball games to keep track of match times (Tonga Ilbo, 3 October 1932: 2).

As part of its efforts to promote punctuality, from 1921 onwards, the Government-General mobilised student and wives' organisations on 10 June to celebrate Time Day (Shi-üi kinyŏmil) (Yi 2008: 147). As it brought together these organisations for a range of activities, newspapers reminded citizens of the importance of the event, which celebrated the introduction of a water clock by 


\section{Roald Maliangkay}

Emperor Tenji (626-672) on that day in 671. In Japan, some politicians opposed the idea, arguing that since no one was unaware of the importance of time, the efforts ought to be directed towards improving a range of public services instead (see The Japan Times, 14 June 1920: 5) A column in the English-language The Japan Times in 1928 explains that the celebration of the day in Japan recognised that the problem of tardiness continued to exist in Japan proper:

The word "Japanese time", which is commonly used among some foreign people and those Japanese who have been in foreign countries, means that Japanese people in general do not keep time punctually, which is indeed true. This peculiar habit has been causing a tremendous loss to the nation, especially in these busy days of industrial and commercial activities. In the face of this shameful habit of the nation it is absolutely necessary to place great importance on the movement for observance of "Time" Day.

(The Japan Times, 10 June 1928: 5) ${ }^{9}$

At least from 1924 onwards a range of activities on the Korean peninsula marked Time Day (see Tonga Ilbo, 12 June 1927: 4; Maeil Shinbo, 9 June 1932: 3; 11 June 1932: 3). At first, these activities largely entailed temples and churches sounding their drum or bell at noon. Later, in 1937, the Seoul fire station sounded its alarm at six o' clock in the morning and afternoon, and at noon, for three minutes each. Presumably because the early hour of this celebration stirred up the wrong sentiment, in 1939 and 1940, when factories and companies took to sounding their sirens on the day, the start of their threeminute alarms was pushed back twice, to respectively seven and then eight o' clock in the morning (see Tonga Ilbo, 10 June 1924: 3; 9 June 1927: 4; Maeil Shinbo, 10 June 1937: 3; 11 June 1938: 2; Tonga Ilbo, 7 June 1939: 2; 10 June 1940: 4). ${ }^{10}$ In addition, the Seoul Radio Station typically broadcast a special programme dedicated to time, free clock service points were set up in the centre of Seoul, and in 1938 a large demountable clock tower was erected in front of the Government-General Building (Tonga Ilbo, 8 June 1932: 2, 10 June 1937: 8, 11 June 1938: 2). ${ }^{11}$ In promoting the day, the government mouthpiece Maeil Shinbo used slogans such as shigan-ün kŭmida (time is gold), shi-wa shigye-rŭl saranghashipshiyo (love time and clocks), shigan-ŭl chik'ija (let's be punctual), and shigye-rŭl parŭge match'uja (let's set our watches correctly) (Ch'oe 2008: 16; Oh 2008: 178-179; see also Tonga Ilbo, 6 June 1931: 3, 11 June 1939: 2; Maeil Shinbo, 10 June 1935: 3, 10 June 1937: 3; Pusan Ilbo, 10 June 1936: 3).

The ever-increasing penetration of capitalist practices acted as powerful propaganda for conformity. Due to their strong association with Western culture and a cosmopolitan lifestyle, timetables and timekeeping instruments served as symbols of modernity and affluence (see Yoo 2008: 115, 133-134; Choi 2013: 85 ). While wall and desk clocks began to decorate modern offices and stores, watches became a popular accessory for middle-class men and women. Yet as in Japan, the popularity of watches, and the weighty early pocket watches in 
particular, was likely curbed by the continued pervasiveness of traditional dress, which did not suit the modern accessory (Uchida 2002: 189). Despite watches' growing popularity, few ads for watches appeared in the first two decades of the twentieth century; those that did usually highlighted a store's wide range of foreign products. ${ }^{12}$ During the 1920s, however, when the fashion for modern urban women began to change towards a more Western look (Joo 2018: 157) and many types of women's wristwatches were introduced, the prevalence of watch ads increased considerably. Sometimes ads associated the product with cosmopolitanism - those for major foreign brands Waltham and Marvin frequently used the image of a globe - or with an active, punctual lifestyle (see Chōsen Shimbun, 3 June 1926: 5; Tonga Ilbo, 15 May 1921: 4, 3 February 1922: 4, 14 September 1932: 7). ${ }^{13}$ But usually the text did most of the promotion and emphasised quality and value. The number of ads for clocks and watches surged around Time Day, when retailers sought to benefit from their products' elevated value (see, for example, Keijō Nippō, 10 June 1936: 3).

As with most other popular trends, watches were first introduced in the Japanese-dominated area of Seoul between Ch'ungmuro and Namdaemun, today's Myŏngdong, at specialty watch shops or one of the four major department stores (Mitsukoshi, Georgia [Chōjiya], Hirata, and Minakai) located there. ${ }^{14}$ Fewer were sold north of this area, in the shopping and entertainment district intended for Koreans, the Korean-owned department stores Hwashin and Tonga likely being their primary outlets. Apart from Seikō, Western brands dominated ${ }^{15}$ because Seikō had cornered the Japanese market by negotiating high tariffs on Swiss watches, in Japan, competitors began to circumvent the tariffs through chablonnage, which entailed the import and assembly of Swiss watch parts on location. This process saw the Japanese import of Swiss watch movements, as opposed to branded Swiss watches, increase several-fold between 1900 and $1940 .{ }^{16}$ In Korea, many ads featured seemingly unbranded watches likely to have been assembled locally. ${ }^{17}$ Over time, competition led to a significant drop in the price of watches. ${ }^{18}$ Western brands remained prestigious, but by the end of the colonial period Seikō watches came to dominate the Korean market, too, because they represented excellent value.

\section{Living in lazy times}

It was in the interest of the coloniser to portray itself as moderniser and driver of prosperity, and to justify its actions by depicting its subjects as having suffered from corrupt governance, and lacking a proper sense of time, so vital to the productivity and order required for their positive transformation (Goudsblom 2001: 29; Nanni 2012: 2-3). Indeed, in line with other colonial powers (Van Schendel and Schulte Nordholt 2001: 11), the Japanese made it known that their subjects were behind the times and lazy (Yoo 2008: 155; Caprio 2009: 85, 88, 207). A few early foreign visitors to Korea arrived at similar conclusions, presumably based on experience, though they may have exaggerated their accounts, for commercial or other reasons. Discussing his experience living and working in Korea 


\section{Roald Maliangkay}

and Japan, for example, photography enthusiast, author and businessman Percival Lowell found that:

Time is purely a Western necessity. The very impersonality and consequent individuality of the far-Oriental renders him superior to it [...]. Time in the far-East is not money. It is only very roughly a measure of value; and in no sense whatever is it a medium of exchange, for it is valueless.

(Lowell 1886: 377, 385)

Some 13 years later, writer-explorer Isabella Bird Bishop noted that while she initially perceived Koreans as lazy, she came to understand that the system of taxes had made profit unattractive to the working class (Bishop 1898: 85-86). In 1913, geographer Ellen Churchill Semple arrived at a similar conclusion: "The Koreans are docile, amiable, lazy, ineffectual. Centuries of oppression and overtaxation have robbed them of all economic incentive. Their ideal is 'honorable idleness'; and to them all idleness is honorable" (Semple 1913: 267).

Publications by individual missionaries or Christian institutions favouring the Japanese colonisation of Korea welcomed reports like these as they justified their efforts to liberate the Koreans from the aimlessness and disorder of the past. In the 1885 issue of the American Methodist journal The Gospel in All Lands, Koreans are described as "exceedingly lazy and dirty", who "would not work if they can help it" and gave foreigners a hard time by not finishing their jobs (5). Fifteen years later, missionary James Scarth Gale wrote, "Until the present time a lack of accuracy has been one of Korea's characteristics [...]. Where is freedom to be found, freedom from past bondage, from present bondage, from the bondage of self, from custom, from fear, from superstition?" (Gale 1909: 117-118, 120; Shin 2017b: 439-440). Similarly, a report in The Chinese Recorder and Missionary Journal of 1 March 1910 argues that conversion to Christianity would resolve the less than ambitious mindset of Koreans: "Because of the oppression for centuries the Korean is often lazy and shiftless, but he is marvellously transformed when he becomes a Christian" (244).

The Japanese knew well that depicting colonial subjects as naturally lazy could ricochet, so they emphasised that the Korean people were victims of centuries of government corruption and worker exploitation. In an interview for The Japan Times in 1906, Dr Kenjiro Ume, described as "a well-known jurist", is quoted as saying:

All people, irrespective of race, possess the desire for happiness, and the Koreans do not necessarily form the exception. As long as they have this desire, they must also desire pleasure from gratifying it. No poverty can overtake the hard worker. Diligence makes one happy and prosperous. Why then do the Koreans appear so lazy? Nothing can account for this fact better than the political corruption.

(27 October: 2 ) 
Even the large-scale migration of Koreans to Manchuria was explained by The Japan Times as caused by "centuries of the native administration. Among other things, that administration had taught the Koreans to be utterly lazy and shiftless" (The Japan Times, 26 April 1913: 5). In an article published by the paper in 1927, K. K. Kawakami acknowledged that "being a new student in the school of colonial management, [Japan] did commit mistakes and blunders, especially in the early stages of her administration in Korea". Adding that many nonJapanese critics "are willing to give Japan due credit for what she has done for the benefit of the Koreans", he provides examples of Western reports that attest to the poor governance that Koreans had previously experienced: "Under the old regime, the masses of Korea were known to be notoriously lazy. Their indolence was not inherent, but was engendered by the corruption and arbitrary actions of the government" (The Japan Times, 1 September 1927: 4).

Soon after annexation, however, Japanese foreign propaganda boasted of its success in raising productivity in Korea. In 1911, The Japan Times cited Professor Johannes Bolljahn of the Foreign Language School in Seoul as saying, "The Koreans used to be a lazy, shiftless lot, but they have been entirely reconstructed" (27 June 1911: 4). In China, on the other hand, such Japanese reports were identified as propaganda early on. Although an editorial in The NorthChina Herald and Supreme Court \& Consular Gazette of 2 May 1914 referred to Koreans as "a people radically gentle and temperamentally submissive, traditionally lazy and inordinately vain" (325), it acknowledged that social conditions had been a major cause for the predisposition and noted that it was important to make "due allowance for a natural desire [among the Japanese] to present the most pleasing facts in the most telling array". A later article (25 December 1920) showed no shift in position: "Those who are familiar with the tactics of Japanese diplomacy during the last few decades will recall that before the Bolsheviks gained the ascendancy in Russia, the Japanese were assiduously engaged in picturing the Koreans as slovenly, lazy good-for-nothings" (878). An editorial in The China Weekly Review on 9 August 1924 also challenged an account of a visit to Korea by Marguerite H. Harrison in the early 1920s, who found Koreans to be "lazy, gossipy, and uselessly argumentative", arguing that if true, "how are we to account for the great sacrifices made by the young Koreans four years ago?" (350).

Koreans did not openly resist the drive towards the improvement of people's time discipline. At the turn of the century, Korean enlightenment intellectuals had attributed Korean laziness and lack of punctuality to the absence of universal timekeeping. Arguing that "unpunctuality is the ill of this country", they saw the implementation of Japan's global time regime as crucial to Korea's progress (Oh 2008: 177-178; Ch'oe 2008: 16). Regardless of how their diligence and sense of punctuality had compared in the past, by the late 1920 s, few Koreans would have disputed the notion that both were virtues, on par with those of their colonisers and superior to any traditional management of time. Although not all Korean people benefited equally from the modern technologies and systems that modernity brought in, they were all affected by the new timekeeping systems to 


\section{Roald Maliangkay}

some degree. They tied them to a global time regime and allowed Koreans to measure their productivity and degree of Westernisation against those of others. The increasingly prevalent use of world time zones and transnational timetables not only heightened Koreans' sense of international connectedness, but also affected the way in which they viewed and organised their public and private activities and engaged and communicated with Japanese and other non-Koreans.

\section{Resisting times}

The experience of the new timekeeping systems differed for men and women. In Japan and Korea, "modern girls" embraced the liberation of women that modernity promised, including its new timekeeping standards. But while in Japan, women made up a significant percentage of the industrial workforce (Harootunian 2000: 12), in Korea, work opportunities for women remained scarce, forcing the majority to become housewives upon marriage. Their relegation to domesticity did not, however, entail a reprieve from the pressure on punctuality and timeliness, as even enlightenment intellectuals advocated good timekeeping as essential to successful household management. ${ }^{19}$ Schools as well as both Japanese and Korean mainstream print media promoted the ideal of a wise mother and good wife. ${ }^{20}$ By educating women about the virtues of modernity and the value of domesticity (Yoo 2008: 70; see also Choi 2009), it was implied that they were to pursue Western fads as a pastime, rather than an ideal. Women, in other words, were to preserve the traditional virtues that allowed a modern family to thrive.

In the early 1920s, when many Koreans were becoming used to new timekeeping systems and technologies, criticism arose of the excessive consumption of watches and other accessories by "modern girls". Such criticism was likely fuelled by misogyny, the loss of the power to rule the nation (see Wells and Robinson 1999: 194), as well as the overt display of wealth or the radical adoption of Western fashion, particularly by kisaeng (young professional female entertainers and courtesans) (see Yoo 2008: 73; Joo 2018: 159). On 2 August 1924, the obsession with fashion accessories led a cartoonist working for the Tonga Ilbo newspaper to depict a modern girl daydreaming of a watch, a ring, a camera and a pair of glasses, while her partner looks on wondering whether more expensive also means more delicate (1). In February 1928, a cartoon in the Chosón Ilbo depicted a line of identical-looking women on a tram holding the commuter strap with their right arms each proudly showing off a wristwatch and ring. In a column for the January issue of Yŏsŏng (Woman) in 1937, Yun Sŏnsang wrote, "If they are still not satisfied, they use up what they have at home and borrow money from a pawnshop to buy a watch, a ring, shoes, and other fashion accessories" (Choi 2013: 85, 165).

From as early as 1907, the eleventh year of the Korean Empire of Kwangmu, the Japanese introduced new commemorative days, including that for Emperor Jimmu, the alleged founder of Japan, and the birthday of Emperor Meiji. While schoolbooks explained the importance of the new commemorations 
(Chōsen sōtokufu 1909: 47-49, 1914, 93-105, 1915: 255-258), the Japanese police prohibited a range of religious and seasonal folk festivals, including stone fights (sŏkchŏn nori) and chariot battles (ch'ajŏn nori) (Kim 2013: 268; Shim Sŭnggu et al. 2015: 145-146). The new official calendar did not kindle a celebratory spirit among the majority of Koreans. Despite their eventual endorsement of the solar calendar, they adhered to it mostly for public or commercial purposes. On the first of January, for example, no major public celebration took place, but the Maeil Shinbo was filled with large ads from Korean companies sending out New Year's wishes to their clientele. Meanwhile, Koreans continued to observe several lunar calendar-based farming and family-related anniversaries and festivals (The National Folk Museum of Korea 2014: 92). Although their opposition was usually silent, ${ }^{21}$ the outbreak of the 1929 Kwangju Student Movement on 3 November, the day on which Emperor Meiji's birthday was celebrated based on the solar calendar, as well as Korea's National Foundation Day based on the lunar calendar, suggests at the very least the continued importance attributed to Korean traditions (Ch'oe 2008: 21).

The Government-General showed little respect for Korean culture. Using terms such as dozoku (indigenous) and minzoku (folk) to refer to Korean customs and belief systems, it portrayed Korean culture as uncivilised and barbarian, and in need of modernisation. Whereas the image of Korea as backward was initially deployed to justify intervention, it also attracted Japanese ethnographers and tourists, who found within it a romantic charm and were not unreceptive to its maintenance. Atkins argues that although some ethnographers in Korea will have resisted the official line, they all benefited from it, and supported it through their choice of subject matter:

Colonial anthropology in Korea may not have been in lockstep with official colonial policy, but the kinds of subject matter judged worthy of ethnographic scrutiny and the sorts of ethnographic images that circulated still legitimised colonial rule by perpetuating common assumptions about the backwardness and exoticism of Koreans and their culture.

(Atkins 2010: 100)

Tourism, meanwhile, relied on the lure of escapism, and prolonging the image of Korean native culture as quaintly backward. Hyung Il Pai notes that for the purpose of authenticity, commercial photos produced by Japanese frequently included "natives" posing (Pai 2014: 127). ${ }^{22}$ Many photo albums produced for Japanese tourists highlighted the slow-moving and disorganised propensity of their colonial subjects, such as in the unpublished 1930s booklet Chōsen füzoku shashin jō (Album of Korean Customs), which features "farmers having a nap" on the side of a rice field. The bizarrely chaotic arrangement of the farmers as they seemingly lie asleep across the narrow path leaves little doubt over the intended meaning of the scene's staging. Since the ideal tourist experience relied on a mix of exoticism and comfort, however, such images were regularly juxtaposed with those of neatly organised shopping streets and modern infrastructure 
(Pai 2014: 159-160). Kern says (1983: 14), "Whatever charm local time may have once had, the world was fated to wake up with buzzers and bells triggered by impulses that travelled around the world with the speed of light". Indeed, the new global time regime did highlight the importance of punctuality, for practical reasons, even for tourists. A series of Japanese postcards from the 1930s called "the everyday lives of Korean women" (Chōsen fujin no aruhi no seikatsu) showed that even the traditional kisaeng understood the notion of timeliness and adhered to a strict daily schedule. The series comprised photographs of kisaeng posing in romantic outdoor scenes next to an illustration of a desk clock, each indicating a different part of the day.

\section{Conclusion}

While the modern, Western calendar did not have a major impact on the everyday lives of Koreans or how they interacted with Japan on a daily basis, the new standards of punctuality and timekeeping did. They were an important aspect of the Japanese efforts to reorganise and optimise the physical, political and economic infrastructures of its new colony. The Japanese institutionalised the new notions and technologies throughout the colony, where they served to increase productivity and efficiency. At home, at school and in the workplace, proper time management was made a precondition to people's involvement and success. While education and the media were instrumental in propagating the new global standards of time management, they were aided in their efforts by international developments and engagements. Although Japanese colonisers and foreign missionaries would never have regarded the Korean people's timeline as identical to their own (see Oh 2008: 7-8), they believed that diligence and effective time management would at least lead Koreans in the right direction. The colonial administration and the Christian mission therefore played a significant role in their propagation and dissemination, and the endorsement of the Christian calendar.

The changes that the timekeeping systems ushered in justified Japan's colonisation and promised returns by maximising productivity and reducing cost. In addition to being associated with functionality and productivity, timekeeping regimens were advocated as markers of success and, along with household consumption, as key components of a modern family's "cultural living" (J.: bunka seikatsu; K.: munhwa saenghwal), a popular discourse in Japanese media in the 1920s that was adopted in Korea and used frequently in advertising (Tongmyong, 4 September 1922: 2; Harootunian 2000: 13-16; see also Yoo 2001: 430). ${ }^{23}$ Train commuters, factory managers, school children, and office employees all required a timekeeping regimen, but even those who did not would come to adopt the new notion of global time eventually.$^{24}$ Punctuality became associated with modernity, with social mobility, and successful business practice. ${ }^{25}$ Ultimately, the notion served to assimilate Koreans, to tie their aspirations to the new Japanese order, and acted as one of the most crucial aspects of everyday practice in transforming relations between Japan and Korea during the first half of the twentieth century. 


\section{Notes}

1 See Okinawa Times, 5 February 1999: 4; Asahi Shimbun, 15 June 2011: 14; Mainichi Shimbun, 27 August 2011: 9, 23 June 2015: 66.

2 See Asahi Shimbun, 26 November 2010: 33, 11 March 2011: 10.

3 Jin-kyung Lee (2010: 23).

4 The Dutch high school teacher Harrebomée, for example, wrote in his 1858 Dictionary of Dutch proverbs that the expression "Oost-Indisch doof" (East Indian deaf), which was applied to those pretending not to hear objections or requests, will have derived from a trait that was "most pertinent to Indonesians, since they manifest a natural tardiness due to the hot climate" (is wel het meest op de Oost-Indiërs toepasselijk, daar hun, door de heete luchtsgesteldheid, eene natuurlijke traagheid eigen is) (Harrebomée 1990 [1858]: 147).

5 Although Japanese farmers did not observe clock time, Thomas Smith (1986: 167) notes that during the Tokugawa period (1603-1868)

time was regarded as fleeting and precious, and great moral value attached to its productive use. Farmers made elaborate efforts to co-ordinate work and to stretch nature's constraints by the skilful use of early and late varieties [...] and other time-saving devices.

6 According to Ch'oe Kyujin, not long after the Treaty the word for time, shigan, was copied from Japanese, which had borrowed the concept from English. The use of the term shigan in the inaugural issue of the periodical Tongnip Shinmun (The Independent) in 1896 may be its first instance in press. See Ch'oe (2008: 14).

7 Schoolbooks began explaining the value of punctuality from as early as 1895 . See Ch'oe Namsŏn (1923: 42-43); Chōsen sōtokufu (1923: 22); Cho (1994: 110-114).

8 Another early clock tower was constructed on top of the National Hospital (Taehan ŭiwŏn) building (today's Seoul University Hospital) in 1906. See Chŏn Uyong (2008: 236).

9 A caption in The Japan Times on 12 June 1933, noted that "Japanese are notorious for their lack of a sense of punctuality" (1).

10 As part of its efforts to promote the importance of punctuality to its employees and the general public, on 10 June 1937, the Yongsan Railway Office also played sirens at specific times and for exact lengths of time, even on its trains. See Maeil Shinbo (10 June 1937: 3).

11 In Sudo, in Hwanghae province, other demountable clock towers were set up around town that played propaganda from gramophones. See Tonga ilbo (14 June 1925: 4).

12 See, for example, Maeil Shinbo (1 January 1915: 3). For extra effect, the Korean Capital Watch Store Inc. (Taehan hwangsŏng haptong shigyep'o) had the Cheguk Shinmun place its ads upside down from 14 April to 3 July 1903. See Cheguk Shinmun (14 April 1903: 3, 9 May 1903: 3, 2 June 1903: 3, 3 July 1903: 3).

13 One watch store ad shows a hand holding a Waltham pocket watch upside down, possibly to highlight its ability to run accurately in any position, and its similarity to a Waltham car dash clock. See Chosŏn Ilbo (28 July 1931: 5; Beikoku waorusamu tokei kaisha 1928: 135).

14 See Seoul t'ŭkpyŏlshi sa p'yŏnch'an wiwŏnhoe (1996: 163). From the 1920s onward, the main stores included the Seoul branch office of the Japanese Ōsawa trading company, the watch stores (tokeiten) Kimura, Tanaka, Tenshindō, Muraki \& Co., and Nakamura, the shops Kashima shōten and Fujikawa shōten, as well as the watch stores (shigyep'o) Ujodang, Meijidō, Shōgodō, Tenpōdō, Shinjongdang, Taewŏndang, and Poshindang. The latter three were all located on Chongno, where shops catered primarily to Korean shoppers. See Tonga Ilbo (15 May 1921: 4, 15 October 1921: 4, 16 October 1921: 1, 7 August 1922: 4, 11 June 1924: 3, 6 October 1924: 3, 10 June 


\section{Roald Maliangkay}

1927: 6); Tongmyŏng (4 September 1922: 2); Chosŏn Ilbo (15 July 1931: 2); Wada (1937: 69-70); Chŏn (2015: 73).

15 Among the brands sold were Waltham, Longines, Elgin, Juvenia, Hafis, Zenith, Seikō, and Tavannes.

16 Tavannes, in particular, was heavily involved in this business. See Donzé (2009: 64).

17 Clocks and watches assembled in Korea represented only a minor share of the total market for these items. In the late 1930s, when the production of watch materials had slowed due to the unavailability of materials, approximately 1 per cent of Japanese watches exported to neighbouring Manchuria was assembled in Korea (Chōsen sōtokufu 1940: 1; South China Morning Post, 10 June 1939: 11).

18 In 1931, a marketing scheme by Lion tooth powder even offered a free chrome watch to loyal customers. See Tonga Ilbo (5 December 1931: 5).

19 The view was expressed in a series of articles entitled "How to improve the household" (Kajŏng-ün ottǒk'e kaeryanghalkka), which ran across several issues of Tongmyŏng ("Ex Oriente Lux") in October 1922.

20 Not unlike Japanese newspapers, advertisements in Korean-language newspapers from the colonial period commonly depicted women in traditional costumes and men in Western suits.

21 Silent resistance was one of many forms in which natives opposed the new time regimen of colonisers. See Nanni (2012: 20).

22 The practice was common among non-Japanese as well. See, for example, Maliangkay (2015: 74).

23 Yoo (2001: 438 n20) equates cultural living with Westernised, modernised living.

24 A seven-day train timetable came into use from 1923. See Tonga Ilbo (19 December 1922: 3).

25 In Korea, watches began to be advertised as useful accessories for (punctual) students in the early 1920s. See Tonga Ilbo (30 September 1921: 4, 11 November 1922: 4, 17 July 1923: 1); Maeil Shinbo (15 June 1923: 3). In Japan, watch sellers targeted both male and female students. See Osaka Mainichi Shimbun (7 April 1927: 8).

\section{References}

Anon. Chōsen füzoku shashin jō [Album of Korean customs] vol. 1, n.d. (c.1930s).

Atkins, E. Taylor. 2010. Primitive Selves: Koreana in the Japanese colonial gaze, 1910-1945. Berkeley: University of California Press.

Beikoku waorusamu tokei kaisha [American Waltham Watch Co.]. 1928. Waltham tokei tokuhon [Waltham watch reader]. Tokyo: Beikoku waorusamu tokei kaisha.

Bishop, Isabella Bird. 1898. Korea and her Neighbours. New York, Chicago and Toronto: Fleming H. Revell Co.

Caprio, Mark E. 2009. Japanese Assimilation Policies in Colonial Korea, 1910-1945. Seattle and London: University of Washington Press.

Cho Yŏnsun. 1994. Han'guk ch'odŭng kyoyug-ǔi kiwŏn [The rise of elementary school education]. Seoul: Hakchisa.

Ch'oe Kyujin. 2008. Kündae-rŭl ponŭn ch'ang 20 [20 windows on modernity]. Seoul: Sŏhaemunjip.

Ch'oe Namsŏn. 1923. Shimun tokpon [Poetry and prose reader]. Seoul: Shinmun'gwan.

Choi, Hyaeweol. 2009. “'Wise Mother, Good Wife': A transcultural discursive construct in modern Korea”. Journal of Korean Studies, 14 (1): 1-33.

Choi, Hyaeweol. 2013. New Women in Colonial Korea: A sourcebook. London and New York: Routledge. 
Chŏn Uyong. 2008. Sŏur-ŭn shipta: Sŏur-ǔi shigonggan-e taehan inmunhakchŏk t’amsa [Longing for Seoul: Humanistic exploration of space and time in Seoul]. Seoul: Tolbegae.

Chŏn Yonggŭn. 2015. Han'guk kŭndae sangp'yo tijain-ŭi pyŏnch'ŏn-gwa munhwajŏk t'ǔksŏng [A study on the change and cultural traits of trademark design in modern Korea], MA thesis, Seoul National University.

Chōsen sōtokufu (Government-General of Korea). 1909. (Pot'ong hakkyo haktoyong) Kugŏ tokpon 4 [Intensive Japanese language reader 4 (elementary school edition)]. Seoul: Chōsen sōtokufu.

Chōsen sōtokufu. 1914. Pot'ong hakkyo sushinsŏ: Kyosuyong [Elementary school selfstudy reader (teachers edition)]. Seoul: Chōsen sōtokufu.

Chōsen sōtokufu. 1915. Sokushū kokugo tokuhon [Intensive Japanese language reader]. Seoul: Chōsen sōtokufu.

Chōsen sōtokufu. 1923. Pot'ong hakkyo sushinsŏ 1 [Elementary school self-study reader]. Seoul: Sŏmubu insoeso.

Chōsen sōtokufu. 1940. Chōsen yuishutsunyūhin sannen taishōhyō [Three-year comparison tables of Korean import and export products]. Seoul: Chōsen sōtokufu zaimukyoku.

Donzé, Pierre-Yves. 2009. "The Swiss Origins of Citizen Watch”. Watch Around, 7: 63-67.

Gale, James Scarth. 1909. Korea in Transition. New York: Eaton and Mains.

Goudsblom, Johan. 2001. "The Worm and the Clock: On the genesis of a global time regime", in Time Matters: Global and local time in Asian societies, edited by Willem Van Schendel and Henk Schulte Nordholt. Amsterdam: VU University Press: 19-36.

Harootunian, Harry. 2000. Overcome by Modernity: History, culture and community in interwar Japan. Princeton: Princeton University Press.

Harrebomée, Pieter Jacob. 1990 [1858]. Spreekwoordenboek der Nederlandse taal [Dictionary of Dutch proverbs]. Hoevelaken: Verba.

Hashimoto, Takehiko. 2008. "Japanese Clocks and the History of Punctuality in Modern Japan". East Asian Science, Technology and Society: An International Journal, 2: $123-133$.

Joo, Kyeongmi. 2018. "Gendered Differences in Modern Korea Toward Western Luxuries", in Fashion, Identity, and Power in Modern Asia, edited by Kyunghee Pyun and Aida Yuen Wong. Cham: Palgrave Macmillan.

Kang Joon-Mann [Kang Chunman]. 2010. “'Ppalli ppalli'-ŭi munhwa chŏngch'ihak Han'gug-ŭi 'sokto k'ŏmyunik'esyŏn'-e kwanhan yŏn'gu [The Cultural Politics of 'Ppalli Ppalli': A study on Korea's 'speed communication']". Ŏllon kwahak yŏn'gu [Journal of Media Studies], 10 (3): 47-80.

Kern, Stephen. 1983. The Culture of Time and Space: 1880-1918. Cambridge: Harvard University Press.

Kim, Kwang-ok. 2013. "Colonial Body and Indigenous Soul: Religion as a contested terrain of culture", in Colonial Rule and Social Change in Korea, 1910-1945, edited by Hong Yung Lee, Yong Chool Ha, and Clark W. Sorensen. Seattle: University of Washington Press: 264-313.

Kim, Kyŏngdong. 2008. Social Change in Korea. Seoul: Jimoondang.

Kim Sŏnghyŏn. 2016. “30-nyŏn Manchuguk kyŏnghŏm-i 60-nyŏndae apch’uk sŏngjang-e yŏnghyang [The experience of Manchuria in the 1930s influenced the pressure on growth in the 1960s]". Chosŏn Ilbo, 8 April: A21.

Lee, Chulwoo. 1988. "Modernity, Legality, and Power in Korea under Japanese Rule", in Cultural Nationalism in Colonial Korea, 1920-1925, edited by Michael E. Robinson. Seattle: University of Washington Press: 21-51. 


\section{Roald Maliangkay}

Lee, Jin-kyung. 2010. Service Economies: Militarism, sex work, and migrant labor in South Korea. Minneapolis: University of Minnesota Press.

Lie, John. 2015. K-Pop: Popular music, cultural amnesia, and economic innovation in South Korea. Oakland: University of California Press.

Lowell, Percival. 1886. Chosön, the Land of the Morning Calm, 2nd ed. Boston, MA: Ticknor and Co.

Maliangkay, Roald. 2015. “The Faux Cosmopolitanism of Korea's Early Visitors: Albums that picture the home audience". English Language and Literature, 61 (1): 69-84.

Methodist Episcopal Church Missionary Society. 1885. "The Country and People of Corea". The Gospel in All Lands, vol. 11, New York: 1-13.

Nanni, Giordano. 2012. The Colonization of Time: Ritual, routine and resistance in the British empire. Manchester and New York: Manchester University Press.

Oh, Se-Mi. 2008. Consuming the Modern: The everyday in colonial Seoul, 1915-1937, $\mathrm{PhD}$ thesis, Columbia University.

Pai, Hyung Il. 2014. Heritage Management in Korea and Japan: The politics of antiquity and identity. Seattle: Washington University Press.

Park, Soon-Won. 1999. Colonial Industrialization and Labor in Korea: The Onoda Cement Factory. Cambridge and London: Harvard University Press.

Said, Edward W. 1979. Orientalism. New York: Vintage Books.

Semple, Ellen Churchill. 1913. "Japanese Colonial Methods". Bulletin of the American Geographical Society, 45 (4): 255-275.

Seoul t'ŭkpyŏlshi sa p'yŏnch'an wiwŏnhoe. 1996. Seoul t'onggye charyojip: Taehan cheguk shigip'yŏn [Collections of Seoul's statistical data: Korean imperial period]. Seoul: Seoul t'ŭkpyŏlshi sa p'yŏnch'an wiwŏnhoe.

Shim Sŭnggu, Hong T'aehan, Im Misŏn, Kang Insuk and Hŏ Yongho. 2015. Ilche kangjŏmgi tanjŏldoen muhyŏng yusan sarye-wa kach 'i-üi chaebalgyŏn [Rediscovering the cases of intangible heritage being discontinued during the colonial period and their value]. Chŏnju: Kungnip muhyŏng yusanwŏn.

Shin Seung-yop [Shin Sŭngyŏp]. 2017a. "Saeroun shigan-jŏk chilsŏro-ŭi yŏhaeng 19-segi mal Chosŏn oegyo sajŏldan mit chishigindŭr-ŭi kŭndaejŏk shigan kyŏnghŏm-e kwanhan yŏn'gu [Exploration of a new temporal order: A study of the experiences of modern time among Korean diplomatic missions and intellectuals at the end of the 19th century]". Journal of Korean Culture, 36: 159-204.

Shin Seung-yop [Shin Sŭngyŏp]. 2017b. "Shigan-ŭl ch'ai-ro, ch'ai-rŭl shigan-ŭro 19-segi mal 20-segi ch'o oegugindŭr-i inshikhan shigan-gwa munmyŏng-ŭi wigye [Difference in time, difference over time: Foreign visitors' view of time and the hierarchy of civilization at the end of the 19th century and beginning of the 20th century]". Han'gukhak yŏn'gu [Journal of Korean Studies], 45: 433-473.

Smith, Thomas C. 1986. "Peasant Time and Factory Time in Japan". Past and Present, 111 (1): 165-197.

The National Folk Museum of Korea. 2014. Tallyŏk, shigan-ŭi chach'wi [Calendars: Tracing Time]. Seoul: The National Folk Museum of Korea.

Uchida, Hoshimi. 2002. "The Birth of Tardiness: The formation of time consciousness in modern Japan”. Japan Review, 14: 173-192.

Van Schendel, Willem, and Henk Schulte Nordholt. 2001. "Time Matters: An introduction", in Time Matters: Global and local time in Asian societies, edited by Willem Van Schendel and Henk Schulte Nordholt. Amsterdam: VU University Press: 7-17.

Wada, Shigeyoshi. 1937. Dai Keijō toshi daikan [Overview of greater Seoul]. Seoul: Chōsen shinbunsha. 
Wells, Kenneth and M. Robinson. 1999. "The Price of Legitimacy: Women and the Kŭnuhoe Movement, 1927-1931”, in Colonial Modernity in Korea, edited by Gi-Wook Shin and Michael Robinson. Cambridge: Harvard University Press: 191-220.

Yi Chŏnghŭi. 2008. “'Shigan-ŭn kŭmida': Shiganp'yo-e match'uŏ ir-ŭl hashio [Time is gold: Please work according to the timesheet]". Minjok 21 [The People 21], 8: 142-147.

Yoo, Sun-young. 2001. "Embodiment of American Modernity in Colonial Korea". InterAsia Cultural Studies, 2 (3): 423-441.

Yoo, Theodore Jun. 2008. The Politics of Gender in Colonial Korea: Education, labor, and health, 1910-1945. Berkeley and Los Angeles: University of California Press. 


\title{
2 "Dye for my grey hair and curry powder for cooking"

\author{
Informal politics of exchange between \\ North Korea and Japan, 1959-1975
}

\author{
Markus Bell
}

Although facing each other across the Sea of Japan/East Sea, Japan and the Democratic People's Republic of Korea (DPRK/North Korea) have never established formal diplomatic ties. ${ }^{1}$ Despite scholarly attention to their complex and often turbulent relationship (cf. Hughes 1999; Hagström and Söderberg 2006; DiFilippo 2012), comparatively little has been said on the informal relations that have facilitated the exchange of people, goods, capital and ideas between the two countries. Specifically, there exists a lacuna of knowledge about the kinship networks that emerged as a result of migration between Japan and North Korea, the significance of such relationships for those who moved and those who stayed put, and the legacy of these movements to countries positioned within mutually antagonistic security arrangements. Such exchanges began with North Korea's aspirations for international legitimacy, and Tokyo's desire to shed its ethnic Korean population, vestiges of its colonial labour force.

From December 1959 until December 1964, some 83,000 people migrated to North Korea as part of a "repatriation movement". ${ }^{2}$ In this chapter I draw on correspondence from Korean and Japanese migrants in the DPRK to family in Japan to illuminate the significance of the informal ties that emerged between Japan and North Korea. I located these documents in the archives of the International Committee of the Red Cross (ICRC). Japanese women wrote many of the letters from the early 1960s to the early 1970s, and Ikeda Fumiko subsequently translated the majority of the correspondence from Japanese into English. I have kept Ikeda's translations as they are, to maintain the authenticity and original meaning of the text. ${ }^{3}$ To written accounts, I add material from interviews with individuals who have returned from North Korea and now live in Tokyo, Osaka, or Seoul. During my fieldwork I worked alongside a returnee in a non-government organisation and lived in close proximity with several returnees in Koreatown, Osaka. ${ }^{4}$ I carried out some 30 semi-structured interviews with returnees from North Korea. Interviews were between one and two hours long and were conducted in Korean.

In this chapter I analyse the artefacts exchanged between divided families from the early 1960s until the mid-1970s as items encoded with multiple meanings: as technologies of remembering that connected migrants in North Korea to family and communities in Japan, and as examples of "informal life politics" 
(Morris-Suzuki 2017). With a focus on social movements in East Asia, MorrisSuzuki, drawing on Anthony Giddens (1994) and Ulrich Beck (2007), defines informal life politics as actions that are "part of an invisible politics that is quietly transforming aspects of life in Northeast Asia" (Morris-Suzuki 2017: 1). Such everyday activities have had broader local, regional, and global repercussions. The letters written by women in North Korea, for instance, took on heightened significance when they arrived in Japan. Instilled with political agency, these letters mobilised the international community to protest against North Korea's alleged human rights violations.

Returnees with whom I spoke, those who migrated to North Korea as part of a mass migration (1959-1984), experienced economic hardship and political persecution in their new home. ${ }^{5}$ In response, many reached out to family and friends in Japan for help. In letters written in a blend of Korean and Japanese, struggling repatriates wrote to mothers, sisters, and daughters in Japan pleading for items that they could trade or sell. To imbue their communications with emotional weight, the authors invoked kinship terminology that reminded recipients of their obligations to support family in need. From 1979, when the Japanese government permitted Zainichi Koreans to travel to see their family, those who could afford to visit North Korea did so. ${ }^{6}$

This chapter asks what transnational exchanges between divided families reveal about consumption, long-distance kinship practices, and transforming Japan-DPRK relations during the Cold War. In what follows I offer examples from letters in the archives of the ICRC to illustrate how food and consumption was central to the narratives of divided families. I then discuss a largely unknown episode of a grassroots movement to bring the Japanese wives of Korean repatriates back to Japan. The movement, led by the sister of a Japanese woman who migrated to North Korea, connected the families of repatriates to anti-communist activism in Japan, South Korea, and the US. This case study reveals how ordinary people experienced a world bifurcated into competing ideological blocs, and how items that moved between them held multiple meanings - as symbols of enduring family bonds and manifestations of long-distance "kin work" (di Leonardo 1987: 442), as tools for survival during hard times, and as evidence of the shortcomings of communism. ${ }^{7}$

\section{Food, identity, and transnational flows}

The mass movement of people from Japan to North Korea was one of the largest organised migrations of the Cold War. From December 1959 until the early days of 1984, 93,340 individuals, mostly ethnic Koreans, and some 6,750 Japanese wives and children, arrived at Niigata from around Japan. Once Red Cross officials had confirmed their decision to leave the country, they sailed several days on a passenger liner to Chongjin, North Korea.

The Japanese government restricted repatriates to taking 60 kilograms of items with them. ${ }^{8}$ As such, whether in hard leather suitcases or cardboard boxes, they carried warm clothes and pictures of loved ones, family records and 


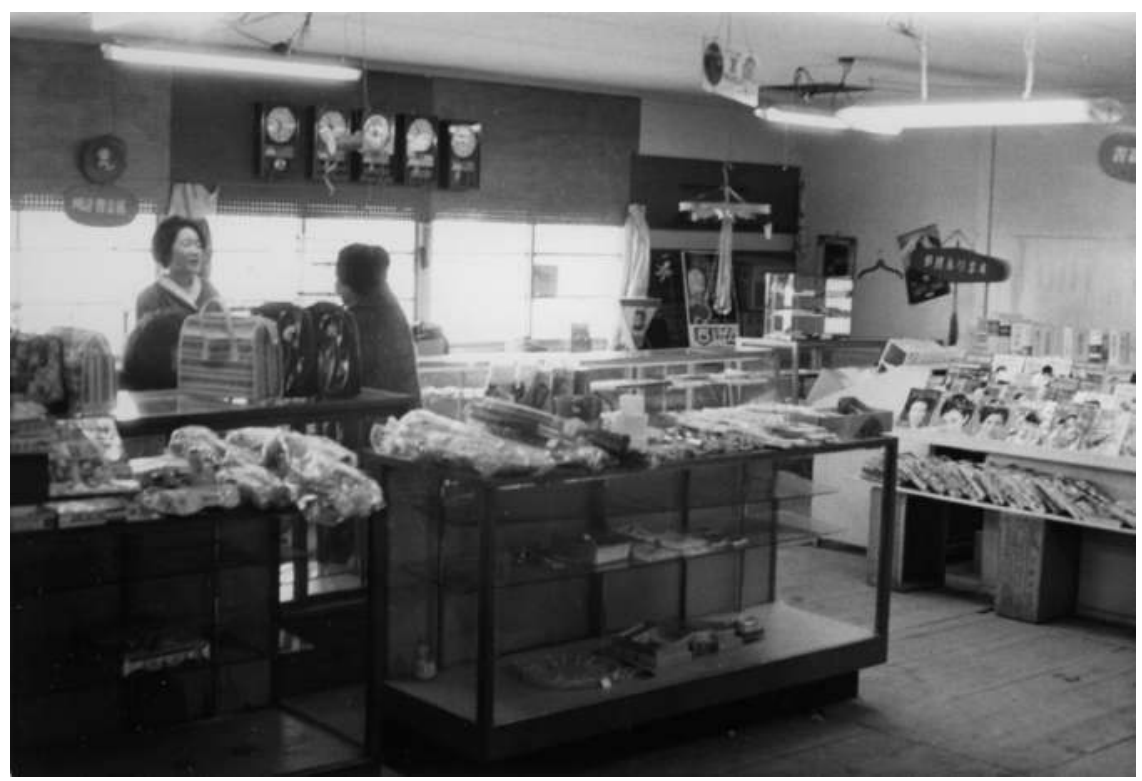

Figure 2.1 Niigata. Store located in the Red Cross Centre.

Source: Photographer: CASAL, ELSA. Copyright: ICRC. Printed with permission.

heirlooms. They also carried foodstuffs and other essentials - noodles, rice, seaweed, dried squid, broth mix, soap, toothpaste, and magazines; items brought from home and last-minute purchases from the Red Cross store as they waited to board their ship.

Food and the cultural practices structuring its consumption provide a window into a complex range of human experiences. This chapter contributes to a growing body of scholarship that takes the trade, preparation, and consumption of food as a starting point to explore the intersection of memory, mobility, and identity (Hoskins 1998; Sutton 2001, 2010; Choo 2004; Avieli 2005; Holtzman 2006; Gibson 2007). When people move, they carry with them things that speak to both life before migration and their anticipated futures. Photographs, for example, become a reference point for families to maintain connections when separated by time, distance, or even death (Empson 2007: 76-77). Such items are mnemonic devices that allow people to claim authority over their past, while fostering a sense of belonging in their new home.

People who migrate by choice may take with them furniture for a new home and items of emotional value, such as pictures, ornaments, and books. But individuals compelled to move by conflict, persecution, or environmental disasters often carry only the bare minimum. Consequently, cultural practices, such as cooking and consuming the staples of the homeland, may be the only means for exiles to maintain a connection to the homeland. 
Food is a particularly efficacious "biographical object" (Hoskins 1998), engaging an array of senses and providing a cognitive trigger that connects present to past. The synesthetic "crossing of experience from different sensory registers" (Sutton 2001: 17) causes the smells, sights, and sounds associated with certain foods to evoke memories of the homeland (cf. Holtzman 2006: 367). For those unable to return home in particular, food takes on heightened significance as a technology of remembering.

\section{Connecting North Korea and Japan}

Japan's defeat in the Second World War and the subsequent dissolution of its empire meant that the Japanese state no longer required a bloated workforce comprising Koreans, Taiwanese, and Chinese. Following the 1952 implementation of the San Francisco Peace Treaty, the Japanese government rescinded the basic privileges that colonial subjects had been afforded in imperial Japan, such as social security and an access to public services and occupational opportunities. ${ }^{9}$ Once stripped of their rights, the number of Koreans in Japan struggling economically increased. The Japanese government pointed to the increase in destitute Koreans as evidence that returning them to their homeland would solve "the Korean problem". ${ }^{10}$

The repatriation movement that started in December 1959 was the result of years of high-level negotiations between the North Korea and Japan

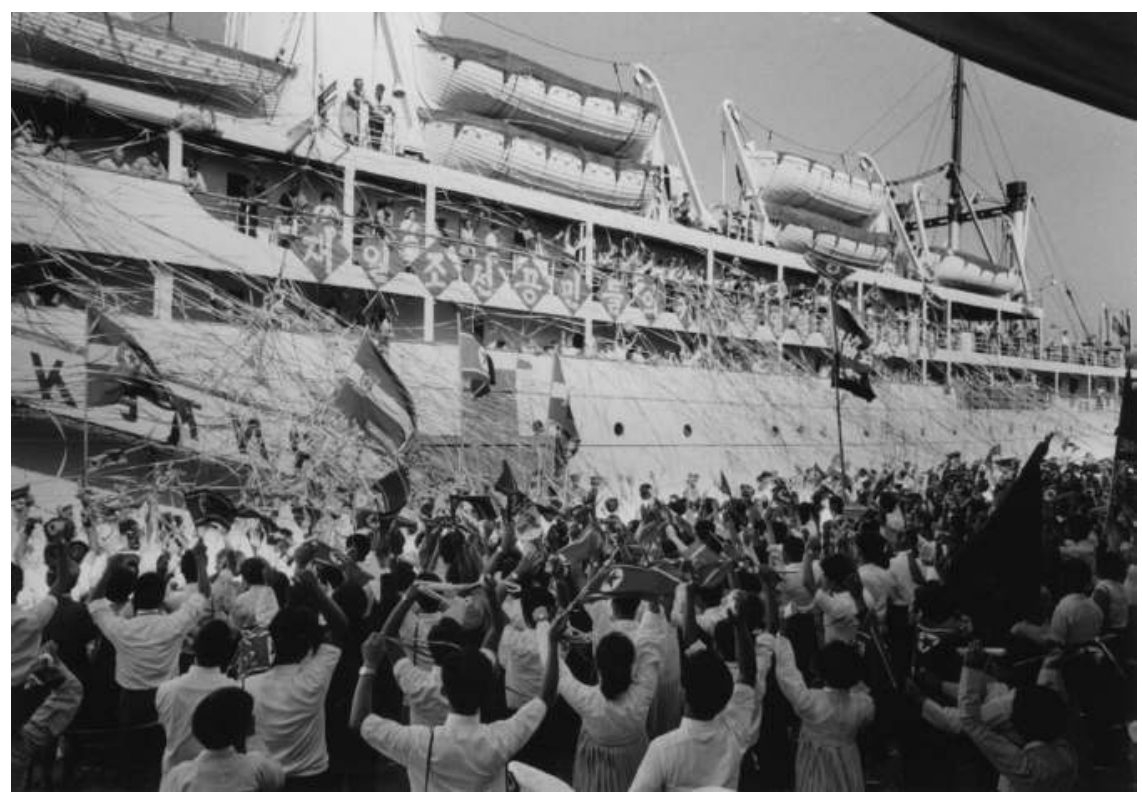

Figure 2.2 Niigata harbour, Japan. Repatriation to North Korea of Koreans living in Japan.

Source: Photographer: CASAL, Elsa. Copyright: ICRC. Printed with permission. 
governments, and their respective Red Cross Societies. All parties promoted the project as a humanitarian venture that would facilitate the return of Koreans struggling to survive in post-war Japan. ${ }^{11}$ The reality, however, was that both the Japanese and North Korean governments used the repatriations to their own ends.

The North Korean government saw the diplomatic value of the project. Specifically, Kim Il-sung understood that accepting thousands of migrants from Japan had the potential to upset nascent Japanese diplomatic relations with South Korea, while at the same time presenting North Korea as a benevolent actor, welcoming disaffected comrades from the capitalist world. ${ }^{12}$ Amidst the two Koreas' competition for legitimacy on the international stage, such a venture was a notable vote of confidence for the communist North.

Both the Japanese print media and propaganda promoted by Chongryon, the DPRK's unofficial representation in Japan, depicted North Korea as "heaven on earth" to Japan's Korean community. ${ }^{13}$ Chongryon members went door to door in Zainichi Korean neighbourhoods to encourage families to emigrate to North Korea, a place where "free education, healthcare, and housing await destitute ethnic brethren". ${ }^{14}$ For thousands of Koreans unable to support themselves, the prospect of a fresh start was too good to ignore.

Men, women, and children; the young and the old; factory workers, farmers, fishermen, rag pickers, home brewers, and entrepreneurs, the wealthy and the unemployed arrived in North Korea and were loaded onto trains bound for their new homes. The government often allocated people with connections to Chongryon - the political elite - apartments in Pyongyang. Others were dispersed to villages, towns, and cities throughout North Korea. Life in the motherland for many repatriates, however, was not as expected.

\section{Letters for food}

For some who set sail on board Soviet passenger liners, the North Korean government's promises initially appeared to bear fruit. ${ }^{15}$ Several of my interlocutors had family who entered the Korean Workers' Party (KWP) and subsequently benefitted from access to tertiary education in Kim Il-sung University. Others became elite athletes, representing the DPRK in sports like ice hockey and softball, or participating in the Arirang Mass Games. For such individuals, emigration initially felt like a sound decision. But these were a select group and, according to an interviewee with family in the KWP, fewer than 1,000 repatriates were able to enter such privileged political circles.

Most families were sent where North Korea needed labour. Some were allocated work in mines or factories; others became optometrists, teachers, or medical practitioners. ${ }^{16}$ Personal correspondence was the best way to communicate with family in Japan. After their arrival, the items that repatriates brought with them were eaten, sold or traded, worn out or, in the case of sensitive documents such as family records, destroyed to keep them from falling into the wrong hands. ${ }^{17}$ Consequently, missing the tastes of home, or needing items unavailable in North 
Korea, repatriates reached out to loved ones left behind. In handwritten letters they asked for money, luxury goods to sell, such as hats, watches, and cloth. They wrote in evocative language that praised their new home, while carefully indicating to the recipient that personal circumstances were at odds with surface prosperity. "Our 6 Year People's Economic Plan which promises us a wealthier life has been carrying on successfully", one letter explained. "So, being all fine, our family could have a new winter thanks to respectful Kim Il-song and the North Korean Labour Party". In the next paragraph, the tone of the letter shifts, however: "Hatsumi and I are unwell right now", writes the author. "I am confined in bed because I worked too hard to secure our winter food - radish leaves. Hatsumi has difficulty in writing letters because of her frequent dizziness". In compositions praising North Korea's leader, repatriated families solicited muchneeded items.

If at all possible, would you arrange to send us 100 scarves and $5 \mathrm{~kg}$ of saccharine from each brother? And if you have something old or waste clothes, please send [them to us]. ${ }^{18}$

Scarves and saccharine could be used at home or sold in local black markets. But such items were a short-term solution to difficult living conditions. Sometimes, repatriates passed on secret messages composed, for example, on the back of postage stamps or embedded in prose that would warn the reader not to follow them to North Korea. According to interviewees, a common trope of such correspondence involved promising to meet once reunification had come to pass. Of course, there was no telling when, if ever, such a momentous event would occur.

Responses, which could take months, arrived inside large Japan post boxes filled with requested items. My interlocutors in Japan, returnees from North Korea, remembered these parcels with fondness. In particular, they recalled ramen noodles and the rich, homely smell of curry roux melting in a pot of boiling water. They also recalled food shortages resulting from harsh North Korean winters, and the unreliable state rationing system. During times of dearth, the government instructed people to come up with novel ways of stretching resources. ${ }^{19}$ It seemed that supplies from Japan could not arrive quickly enough, as difficult circumstances confronting new arrivals meant that foodstuffs received from Japan were needed to compensate for dwindling state rations.

\section{An onion existence}

The arrival of correspondence to anxious families throughout Japan mobilised recipients at both local and national levels. Throughout the country, parents and siblings of people who had left for North Korea sent dried foodstuffs, chewing gum, rice crackers, chocolates, sachets of food flavouring, stationery, clothes, medicines, and Japanese currency. One woman's letter to her sister, on 22 February 1967, requests "anything you don't need in Tokyo". She then specifies: "Chaho's daddy goes on business trips quite often, he needs a wristwatch. 
I know it is impolite to write such a demanding letter. However please do understand". She continues, "As we cannot eat rice here, I can't breast feed my baby. The milk was sent from Japan, but there is no feeding bottle". ${ }^{20}$

Personal communications underlined the day-to-day challenges experienced by many repatriated families. In another letter, dated 6 February 1970, 43-yearold Sumi laments, "We are dragging on an 'onion existence' by selling clothing one item after another. ${ }^{21} \mathrm{We}$ are in needy circumstances". She continues,

Then I ventured to write you this letter to save our financial difficulty. If you would send us 300 neckerchiefs which are 100 percent nylon, I can eke out our livelihood. As it was summer when we left Japan, we didn't bring clothes for winter. It is intensely colder here than Japan [...]. If you can send sweaters, socks and under-shirts for winter, we [would be] very happy. And I need oil penicillin and medicines [for] kidney trouble, liver trouble, gastro paresis and gastritis for my illness.

Sumi's requested neckerchiefs were useful as bribes for gaining favour with local cadres. In another letter, she explained "To be honest, I really need several wrist watches and tetron clothing materials which have to be bartered for food". ${ }^{22}$ Luxury items made in Japan were highly regarded by North Koreans. One interlocutor told me that she traded these goods for rice, kimchi, and other foods that she used to feed her family. Foodstuffs that would have been commonplace in Japan were also imbued with greater significance once they arrived in North Korea, as items with the potential to facilitate socioeconomic upward mobility, and as expressions of diverging ethnic and political identity from North Koreans.

Repatriates to the DPRK, both ethnic Koreans and the almost 7,000 Japanese who accompanied them, soon discovered that local North Koreans often regarded them as little different from Japanese (Bell 2018a). In the previously cited letter to her uncle and aunt, Sumi explains that she took on the Korean name Sumi because "Japanese names are disliked by North Korean people". Wishing for more than tradable items and medicine, she adds a postscript, "Please send dye for my grey hair and curry powder for cooking, too". Even under the grimmest of circumstances, such comforts from home helped recipients maintain dignity, while connecting them to family in Japan.

Food and consumption are an integral part of the memories of those who moved to North Korea and later returned. For example, one author, named Koichi, writes, "Uncle Hiroyuki, we have received your heart-warming parcel post ... You have sent us really useful things. Our everyday meal has become a lot [more] delicious with Ajinomoto". ${ }^{23}$ The fond memories that repatriates associated with life in Japan were integral not only in maintaining emotional connections to those left behind but also in shaping a transnational sense of belonging for those born in North Korea. ${ }^{24}$

The first generation born in North Korea to repatriated parents inherited their parents' longing for a time and place other than the North Korean present. In repatriate homes, out of earshot of locals, repatriated families spoke Japanese, 
recalled stories about life in Japan, and cooked with Japanese ingredients. The often-complex biographies of repatriates meant that the use of Japanese cooking ingredients, and the smells, tastes, and textures of items that arrived on the passenger ship, brought to mind more than just the sights and sounds of Osaka, Kobe, or Tokyo. One interviewee recalled that, because her grandfather was from Cheju Island and her Japan-born father migrated to North Korea in his late twenties, the cooking in her home mixed Cheju, Japanese, and North Korean styles. Such examples underline the power of memories inspired by food, and the messiness of nostalgia that connects to multiple settings.

Migrants make and remake cultural identities by reconnecting to the homeland in what Sutton describes as a "returning to the whole" (2001: 17). As a technology of memory and identity, the food items families received from Japan reveal a frequently overlooked rendering of Japanese-North Korean relations, and an alternative to inter-state dealings at the governmental level. The imagined, informal, personal yet very real and important relations sustained people across borders, even when diplomatic ties were virtually non-existent. The ingredients that were boiled, sprinkled, and stirred into each dish acted as sensory reminders of alternative modes of belonging and an imagined community that reached beyond the sovereign borders of North Korea, to Japan and even to South Korea.

Consuming Japanese food products was a significant aspect of life recalled by interviewees and a recurring subject in the letters from North Korea. Food shortages were an equally important theme in the correspondence of repatriated family. Interlocutors told me of the hardships they endured during the "Arduous March", as the 1990s famine is known in North Korea. ${ }^{25}$ As the economy crumbled and the state rationing system ground to a halt, repatriated families were forced to come up with new ways to feed themselves.

A shortage of food staples made life challenging for repatriated families. One Japanese woman's letter laments the difficulty of finding foods that she enjoyed in Japan. "Things are certainly harsh over here", she explains, remembering the food their family enjoyed in Japan, "I would often [eat] squid sashimi mother had prepared for us. I have never seen live fish either here. I live on the sort of food without calculable calories [...]". ${ }^{26}$ Another woman pleads for diapers and food for her baby in a letter to her sister. "People here are incredibly poor", she explains. "I am sorry my letters are always unpleasant".

Over several decades, however, the emotional and financial burden of supporting family in North Korea took a toll on kinship relations already stretched by time and distance. Many letters to Japan thus went unanswered. Interviewees confirmed that their relationships to family in Japan became strained, if not entirely dissolved, by the constant requests for help.

\section{Mobilising correspondence from North Korea}

In the mid-1970s, Ikeda Fumiko, a resident of Setagaya-ku, Tokyo, founded the Association for Human Rights of Japanese Wives of North Korean Repatriates 
(AHRJW). Ikeda, who had not heard from her sister since she went to North Korea in the early 1960s, started collecting letters such as those cited above. She soon became known for helping the families of repatriates. Specifically, Ikeda collected letters from Japanese wives of Koreans who had gone to North Korea and family of repatriated Japanese wanting to know what had become of their kin. Japanese who migrated to North Korea usually spoke no Korean and had little knowledge of what awaited them. Prior to departure, some of these women had heard that they would be able to return after three years. ${ }^{27}$ Whether this opportunity to return was official policy or simply a rumour is unclear as, in actuality, no one was permitted to go back to Japan.

Desperate to contact relatives who, in some cases, had not been heard from since they left for North Korea, the families of Japanese repatriates mobilised around Ikeda. One such letter, written by a Mr Yamada Yoshio in October 1974, and subsequently translated into English and sent to the United Nations (UN) by Ikeda, explained:

One day a North Korean who belonged to the General Federation of North Korean Residents in Japan came and said [to my sister], "You should go to North Korea because North Korea is paradise". Her parents, brothers and sisters discouraged her marriage with a North Korean and her plan to go to North Korea very much $[\ldots]$ but her husband who is very strong finally persuaded her and she left for North Korea. ${ }^{28}$

Many AHRJW members had spent over a decade sending packages to support their kin. With Ikeda as their representative, the organisation used the letters as evidence that all was not well in North Korea. Throughout the 1970s, Ikeda translated the correspondence she received into English and later presented it as part of a petition to the Japanese Ministry of Foreign Affairs, the Japanese Red Cross Society, and the ICRC. AHRJW demanded that a fact-finding mission be sent to North Korea to locate family members and arrange their return to Japan.

In addition to lobbying Japanese and international organisations, Ikeda and the members of AHRJW visited the Korean Demilitarised Zone and campaigned to raise public awareness in South Korea and Japan. In need of answers, they delivered questionnaires on the status of their relatives to Chongryon representatives. They also petitioned Han Duk Soo, chairman of the Central Headquarters of North Korea's unofficial representation in Japan. In an October 1974 report, the group explained that Chongryon had responded to their requests with "violent words and threats that criticised the Japanese government". ${ }^{29}$

When efforts to rally the Japanese public yielded little success, they wrote a detailed petition to the UN. In a letter to UN Secretary General Kurt Waldheim, Ikeda explained that the Japanese government and Red Cross had approached the Red Cross Society of the DPRK for information on the whereabouts of Japanese wives, but that the North Korean government had rebuffed all such requests. Ikeda thus asked Waldheim to send a fact-finding mission to North Korea, "in order to make the full list and to make public the real situation of the Japanese 
wives". ${ }^{30}$ The petition cited the December 1948 Universal Declaration of Human Rights, arguing that North Korea was violating the fundamental human rights of Japanese wives and their families who were living in a "prison without bars".

The petition to the UN included details of family members who had gone to North Korea and subsequently disappeared. One such letter, from Yoshimura Masao in Taku city, Kyushu, explains:

Dear Sir, I have one younger sister who went to North Korea in 1960. Since then, there haven't been any letters from her. I heard a rumour that she died four or five years ago. But no official news about her death was ever brought to me. If she is really dead, I'm afraid that she was never given a decent burial and must be quite uneasy in the spirit world. ${ }^{31}$

Yoshimura's concerns for his sister are echoed in many other letters sent to the UN headquarters. For example, a letter from Hasegawa Michi of Niigata asks the UN to help her see her daughter before she dies:

They [repatriates] believed the propaganda of North Korea and also believed that they could come back to Japan in three years. When I heard of this movement for Japanese wives in North Korea I communicated with Mrs. Ikeda. But, to my surprise, the people of [Chongryon] called and threatened us saying, "If you continue with this movement for Japanese wives in North Korea, your daughter in North Korea will be harmed". ${ }^{32}$

Hasegawa's report of Chongryon threats appears in other letters, too. Although representatives of the North Korean government expressed concerns about such negative exposure, Ikeda and her supporters were not to be deterred.

The movement to return family members from North Korea gathered further momentum with the creation of the American Committee for Human Rights of Japanese Wives of North Korean Repatriates. In a demonstration of solidarity designed to pressure the UN, in October 1974 members of this group organised a seven-day fast in support of Japanese wives in North Korea. ${ }^{33}$ Ultimately, however, anxious mothers and sisters would come no closer to reuniting with their family, as North Korea steadfastly refused requests for a fact-finding mission. The men and women who have since returned to Japan did so in the years following the North Korean famine (1994-2000), using people smugglers to secret themselves across the Sino-North Korean border. Once in China, many of the returnees with whom I worked had flown to Japan with the help of Japanese Consulate General staff. To date, Japanese non-government organisations working with returnees estimate that there are around 300 such people currently in Japan.

\section{Conclusion}

In this chapter I have examined a set of informal transnational exchanges that emerged between Japan and North Korea throughout the 1960s to the early 
1970s. Although the two countries have never established formal diplomatic relations, the kinship networks of divided Korean and Japanese families facilitated the movement of people, capital, and goods across the Sea of Japan/East Sea throughout the latter half of the twentieth century.

This chapter has also highlighted the multiple and often unanticipated shifting significations of items that move across time and space - as symbols of Japanese family life, as items that could be used for political gain in North Korea and, in the most extreme circumstances, as the difference between life and death during food shortages. In letters from North Korea, people who had been part of a mass migration from the capitalist to the communist world re-established and maintained contact with family and friends in communities throughout Japan. Requests for money, medical supplies, warm winter clothes and food permeated the pages of correspondence to loved ones. For some families struggling in their new home, the essentials might suffice. For others, the tastes of cooking powder, curry roux, or candy reconnected repatriates to families and hometowns they had left behind and fostered a transnational sense of belonging between North Korea and Japan.

Although kinship-based exchange between Japan and North Korea continues to this day, it has diminished since the 1980s. The slowing of informal exchange is due to several factors, including the weakening of family ties, Japanese economic sanctions imposed in response to the DPRK's missile and nuclear testing, and a new generation of Zainichi Koreans who identify with North Korea in different ways from their parents (cf. Bell 2018b). Consequently, the repatriation movement and transnational exchanges that followed have largely been forgotten, along with the thousands of Koreans and Japanese who left Niigata for Chongjin.

In this chapter I have not tried to argue that the informal relations emerging between divided families played the same role as formal diplomatic ties. Rather, during a period when relations between the communist and capitalist world were largely limited to highly circumscribed diplomatic interchange, repatriates' letters that drew attention to straitened conditions in their new home contradicted DPRK state propaganda. Family members in Japan subsequently used the letters as evidence of the North Korean state's failure to discharge its duty of care towards new arrivals. As an example of informal life politics, the mobilisation of family members and supporters in lobbying the Japanese and North Korean governments and the UN underlines the significance of these letters as both a lifeline for survival in times of extreme hardship, and as testimony of DPRK state abuses.

The informal transactions between North Korea and Japan show that even under the most desperate of circumstances, at a time when fraternisation between two ideologically antagonistic blocs was considered an act of treason, divided families found ways to maintain relationships and to send messages of hope. Regardless of geopolitical divisions, the things they carried and the items that traversed Cold War boundaries fostered transnational modes of belonging, as an imagined community emerged connecting family in Japan to loved ones in North Korea. 


\section{Notes}

1 I would like to thank the returnees from North Korea with whom I worked in Japan. Without their help, this story could not be told. I would also like to thank the in-house historian of the ICRC, Fabrizio Bensi, for his help in accessing archived documents. Lastly, thank you to Jarrod Clyne, Kim Kyungmook, Ishimaru Jiro, Christine Knight, Rosita Armytage, and the editors of this volume, Stephen Epstein and Rumi Sakamoto, for their support.

2 B AG 232 105-019.01: Reports by the Japanese Immigration Control Bureau.

3 I also worked with letters from repatriates written in Korean that an interlocutor in Osaka permitted me to read, but I have not included these letters in this chapter.

4 The fieldwork for this chapter took place between 2014 and 2018 and included almost a year of ethnographic research in Seoul, South Korea, Osaka and Tokyo, Japan (2014-2015) and three visits to the archives of the ICRC in Geneva, Switzerland $(2015,2016,2018)$.

5 Calling the mass migration from Japan a "repatriation" requires unpacking, because the majority of individuals to go to North Korea were originally from southern Korea. So-called repatriates were far more likely motivated by a desire for the upward social mobility that had eluded them in Japan, or an ideological affinity with the Communist DPRK. For more on the complexities of the repatriation movement, see MorrisSuzuki (2007).

6 In 1971 a regular maritime link between North Korea and Japan was established. This route was primarily used in the movement of people, heavy and light machinery, and information to North Korea. In 1979 the Japanese government further eased restrictions following Japan's signing of both the International Covenant on International Human Rights and the 1982 UN Refugee Convention. From this time, Zainichi Koreans in Japan were permitted to travel to and from North Korea.

7 Kin work, according to di Leonardo (1987), is the labour put into maintaining kinship relations. This form of work is usually regarded as the domain of women.

8 According to the Guidebook for Returnees, Japan Red Cross Society. September 1959: 3 .

9 The San Francisco Peace Treaty, signed between the Allied Powers and Japan on 8 September 1951, officially ended the American-led Allied occupation of Japan.

10 B AG 232 105-002: "Fundamental Conditions of Livelihood of Certain Koreans Residing in Japan".

11 Chongryon representatives disseminated DPRK propaganda throughout Japan. The Japanese government relied on the media to promote the repatriation project as a "humanitarian project". Through vigorous lobbying, the Japanese Red Cross Society convinced the ICRC to oversee the repatriations, lending legitimacy to the project while also divesting responsibility from the Japanese and North Korean governments.

12 At the time, the Republic of Korea and Japan were working towards a muchanticipated normalisation of relations. News that Japan was facilitating the movement of Koreans to the DPRK provoked a diplomatic furore in South Korea, with bipartisan opposition to the project in the National Assembly and government-organised protests throughout the country.

13 Chongryon, or "The General Association of Korean Residents in Japan" ("Chôsen Sôren" in Japanese), functions as North Korea's de facto representation in Japan.

14 According to a booklet published by the Pyongyang Foreign Languages Publishing House in 1959.

15 Soviet troops were assigned to guard the transport ships from the threat of attack by South Korean vessels.

16 Neither the Japanese nor the North Korean governments had made contingency plans for individuals who wished to return to Japan. In the years following the beginnings of the repatriation movement, the North Korean side lobbied for free movement 
between North Korea and Japan. Tokyo, concerned that free travel would allow North Korea a de facto normalisation of diplomatic ties, and that it would use free movement for gathering intelligence, refused to acquiesce.

17 Items such as family records (chokpo, in Korean) that pointed to kinship connections to South Korea were problematic in North Korea, where they were regarded as contrary to socialist revolutionary ideology and evidence of divided loyalties.

18 B AG 232 105-046: "The Association for Human Rights of Japanese Wives of North Korean Repatriates" 21/06/1974-13/01/1975.

19 My interlocutors recalled, for example, the government petitioning citizens to "Eat two meals a day". Such calls to reduce consumption were couched in the language of struggle, and people were urged to "fight for victory" by making resources last longer. For more on the language of deprivation as it emerged in North Korea during the 1990s famine, see Fahy (2015).

20 B AG 232 105-046: Letter from Tamako, 22 February, 1967.

21 In the original translation Ikeda uses the expression "onion existence".

22 B AG 232 105-046: Letter from Sumi, 6 February, 1970.

23 Ajinomoto is a food corporation in Japan that produces monosodium glutamate powder.

24 For more on the imagined transnational sense of belonging that developed between migrants to North Korea and their family who stayed in Japan, see Bell (2018a).

25 For more on the North Korean famine, see Haggard and Noland (2007).

26 B AG 232 105-046: "Letter from Japanese wife to her brother", date unspecified.

27 An interviewee confirmed her evidently mistaken impression that she would be permitted to return prior to leaving North Korea. She remained in North Korea for 40 years before managing to cross into China.

28 B AG 232 105-046.01: Lettres des familles des épouses japonaises de Coréens rapatriés en Corée du Nord, 10/09/1974-19/10/1974, Letter dated 8 October, 1974.

29 B AG 232 105-046: "Realization of Free Travelling of Japanese Wives of North Korean Repatriates and Sending Fact-Finding Mission", 7 October, 1974.

30 B AG 232 105-046: "Petition for Sending Fact-Finding Mission to North Korea \& Realizing Free Visits to Japan by Japanese Wives of Korean Repatriates", 17 June, 1974.

31 B AG 232 105-046.01: Lettres des familles des épouses japonaises de Coréens rapatriés en Corée du Nord, 10/09/1974-19/10/1974, Letter dated 17 October, 1974.

32 B AG 232 105-046.01: Letter dated 15 October, 1974.

33 Interestingly, many people associated with the movement to return Japanese wives to Japan were members of Reverend Moon Sun Myung's Unification Church, including Ikeda Fumiko.

\section{References}

Avieli, Nir. 2005. "Vietnamese New Year Rice Cakes: Iconic festive dishes and contested national identity". Ethnology, 44 (2): 167-187.

Beck, Ulrich. 2007. World at Risk. Cambridge: Polity Press.

Bell, Markus. 2018a. "Patriotic Revolutionaries and Imperial Sympathizers: Identity and selfhood of Korean-Japanese migrants from Japan to North Korea". Crosscurrents: East Asian History and Culture Review, 7 (2): 1-25.

Bell, Markus. 2018b. "Reimagining the Homeland: Zainichi Koreans' transnational longing for North Korea”. The Asia Pacific Journal of Anthropology, 20 (1): 22-41.

Choo, Simon. 2004. "Eating Satay Babi: Sensory perception of transnational movement". Journal of Intercultural Studies, 25 (3): 203-13.

di Leonardo, Micaela. 1987. "The Female World of Cards and Holidays: Women, families, and the work of kinship". Signs, 12 (3): 440-453. 
DiFilippo, Anthony. 2012. US-Japan-North Korea Security Relations: Irrepressible interests. New York and London: Routledge.

Empson, Rebecca. 2007. "Enlivened Memories: Recalling absence and loss in Mongolia", in Ghosts of Memory: Essays on remembrance and relatedness, edited by Janet Carsten. UK, Australia and USA: Blackwell Publishing Ltd: 58-82.

Fahy, Sandra. 2015. Marching through Suffering: Loss and survival in North Korea. New York: Columbia University Press.

Gibson, Sarah. 2007. "Travelling, Dwelling, and Eating Cultures". Space and Culture, 10 (1): 4-21.

Giddens, Anthony. 1994. Beyond Left and Right: The Future of radical politics. Cambridge: Polity Press.

Haggard, Stephan and Marcus Noland. 2007. Famine in North Korea: Markets, aid, and reform. Columbia University Press.

Hagström, Linus and Marie Söderberg (eds). 2006. North Korea Policy: Japan and the Great Powers. New York and London: Routledge.

Holtzman, Jon. 2006. "Food and Memory". Annual Review of Anthropology, 35 (1): 361-378. doi: 10.1146/annurev.anthro.35.081705.123220.

Hoskins, Janet. 1998. Biographical Objects: How things tell the stories of people's lives. New York and London: Routledge.

Hughes, Christopher. 1999. Japan's Economic Power and Security: Japan and North Korea. New York and London: Routledge.

Morris-Suzuki, Tessa. 2007. Exodus to North Korea: Shadows from Japan's Cold War. Plymouth, United Kingdom: Rowman \& Littlefield Publishers.

Morris-Suzuki, Tessa. 2017. "Introduction: Informal life politics in Northeast Asia", in Morris-Suzuki, Tessa and Eun Jeong Soh. New Worlds from Below: Informal life politics and grassroots action in twenty-first-century Northeast Asia. Asian Studies Series, ANU Press.

Sutton, David. 2001. Remembrance of Repasts: An anthropology of food and memory. Oxford and New York: Berg.

Sutton, David. 2010. "Food and the Senses". Annual Review of Anthropology, 39: 209-223.

United Nations Commissioner for Refugees. www.unhcr.org/figures-at-a-glance.html.

\section{Archival references}

B AG 232 105-002: Fundamental Conditions of Livelihood of Certain Koreans Residing in Japan.

B AG 232 105-046: The Association for Human Rights of Japanese Wives of North Korean Repatriates 21/06/1974-13/01/1975.

B AG 232 105-046.01: Lettres des familles des épouses japonaises de Coréens rapatriés en Corée du Nord, 10/09/1974-19/10/1974.

"On the Question of 600,000 Koreans in Japan". 1959. Foreign Languages Publishing House, Pyongyang, Democratic People's Republic of Korea.

The Guidebook for Returnees, Japan Red Cross Society. September 1959. 


\title{
3 The "Shiba view of history" and Japan-Korea relations Reading, watching and travelling Clouds Above the Hill
}

\author{
Philip Seaton
}

In August 2015, Japanese Prime Minister Abe Shinzo issued a statement marking the seventieth anniversary of the end of the Asia-Pacific War that contained the following interpretation of events during the Meiji period (1868-1912):

More than one hundred years ago, vast colonies possessed mainly by the Western powers stretched out across the world. With their overwhelming supremacy in technology, waves of colonial rule surged towards Asia in the 19th century. There is no doubt that the resultant sense of crisis drove Japan forward to achieve modernisation. Japan built a constitutional government earlier than any other nation in Asia. The country preserved its independence throughout. The Japan-Russia War gave encouragement to many people under colonial rule from Asia to Africa.

(Abe 2015)

Abe's interpretation of the "encouragement" given to "many people under colonial rule from Asia to Africa" by Japan's victory in the Russo-Japanese War (1904-1905) sidelined the war's role in paving the way for Korea to be placed under Japanese rule as a protectorate (from 1905) and then colony (1910-1945). Furthermore, it constituted a substantially different position from the statement by Kan Naoto in 2010 marking the centenary of the annexation of the Korean peninsula, which stated "the Korean people of that time was deprived of their country and culture, and their ethnic pride was deeply scarred by the colonial rule which was imposed against their will under the political and military circumstances" (Kan 2010).

Negative reaction to Abe's statement in Korea was widespread. Gil YuHyung of the progressive Korean newspaper The Hankyoreh compared Abe's statement with the historical views of Japanese novelist Shiba Ryōtarō as expressed in perhaps Shiba's best-known work Clouds Above the Hill. The novel, which was serialised in the Sankei Shimbun newspaper between 1968 and 1972, depicts Japan during the First Sino-Japanese War (1894-1895) and the Russo-Japanese War through the eyes of its three main characters: the Akiyama brothers (Yoshifuru, who served in the cavalry, and Saneyuki, who served in the navy) and poet Masaoka Shiki. 
The major theme of the novel is that Japan had to fight - and ultimately defeat - Russia to keep Korea from falling into its clutches. Under this view of history, the wars that Japan waged against China and Russia during the Meiji Period to bring Korea under its dominion are transformed into pleasant memories from a golden era. In contrast, the wars during the Showa Period that began with the Manchurian Incident in 1931 are decried as mistakes that undid everything achieved during the Meiji Period, including the annexation of Korea.

This understanding of history was thoroughly reflected in the statement released by Japanese Prime Minister Shinzo Abe on Aug. 14.

(Gil 2015)

By linking a work of popular culture to official narratives, Gil identified an example of how popular culture may impact deeply upon Korea-Japan relations. As other chapters in this book indicate, popular culture can perform a variety of roles: establish dominant narratives that shape public opinion (Ria Shibata); create fantasies of the "other" that facilitate newfound interest and exchanges (Chris Perkins); stir controversies that whip up anger or xenophobia (Stephen Epstein); and even make reconciliation a central theme (Rumi Sakamoto). However, post-war or postcolonial reconciliation between nations is built upon stable, mutually acceptable official government positions regarding past histories of violence. If, therefore, Shiba Ryōtarō's writings are "the historical tale behind Abe's statement" (Gil 2015), the "Shiba view of history" (Shiba shikan) assumes a pivotal role within contemporary Korean-Japanese relations as a barrier to reconciliation.

This chapter discusses the origins, nature and implications of the "Shiba view of history" (Shiba shikan) with reference to discussion of Korea in the novel considered to present the clearest example of the view: Clouds Above the Hill (Saka no ue no kumo). Reading the novel in tandem with the NHK Taiga Drama adaptation (broadcast 2009-2011) and associated tourist sites illustrates the interplay between popular culture and official narratives, and their potential impact on Korea-Japan relations.

\section{Shiba Ryōtarō and his "view of history"}

Shiba Ryōtarō (1923-1996) was one of Japan's most popular and prolific novelists. He served in a tank unit during the Asia-Pacific War and later became a journalist for the Sankei Newspaper. He is best known for his historical novels, serialised first in newspapers, and then released as books. His protagonists were mainly famous figures from the Warring States (1467-1603), Edo (1603-1867), Bakumatsu (1853-1867), and Meiji (1868-1912) periods. Shiba travelled extensively and wrote non-fiction essays, too. His over 500 books won numerous prizes, are still widely read, and have sold hundreds of millions of copies. Often revered as a "national author" (kokumin sakka), Shiba's legacy is preserved in the Shiba Ryotaro Memorial Museum ${ }^{1}$ on the site of his house in Osaka. 
In his novels, Shiba attempts to adhere to the historical record. Donald Keene wrote about his writing process:

[Shiba] first amassed a large collection of source materials that he carefully read over until he was thoroughly familiar with the facts behind the story he was about to relate; but once he actually began writing, he did not hesitate when necessary to intuit what the characters in his stories had thought or said on a particular occasion.

(Keene 2003: 95)

Isoda Michifumi also notes Shiba's historical accuracy, particularly in Clouds Above the Hill. Isoda distinguishes three literary genres in descending order of proximity to academic history - historical biography (shiden bungaku), historical novels (rekishi shōsetsu), and period novels (jidai shōsetsu). While many of Shiba's works set in earlier periods are historical novels in this schema, Isoda categorises Clouds Above the Hill as historical biography given its adherence to documentary evidence (Isoda 2017: 18). As we will see, however, Shiba also has critics on points of accuracy, as well as interpretation.

The Shiba view of history is particularly associated with Clouds Above the Hill and gives a positive evaluation of the Meiji period (Gil 2015; see also Hirano et al. 2008: 258). The implications for Korea-Japan relations are stark. The Meiji period was when Japan began in earnest its empire-building, wrestled control of the Korean peninsula from China, and warded off Russian ambitions to do the same. Shiba's evaluation of Meiji as Japan's brightest moment before taking a wrong turn cannot sit well with Korean views of the period. As Guy Podoler and Michael Robinson conclude:

During the Russo-Japanese War Japan succeeded in furthering its hold over Korea. The victory over the last contender for influence in Korea cleared the way to the annexation of 1910 . For Koreans this period signifies the dark dawn of colonial rule $[\ldots]$.

(Podoler and Robinson 2007: 196)

To understand the origins of Shiba's view of the Meiji period, one must look at his broader writings on Japan and Japaneseness. As Naoko Shimazu notes, "Fundamentally, his undying interest was the question of Japanese identity", and Shiba's writings had great influence on debates over nihonjinron, theories of Japaneseness (Shimazu 2009: 278). Exegesis of Shiba's work often reflects this impact. For example, in a two-part NHK Special documentary titled "Shiba Ryōtarō shisaku kikō" (Shiba Ryōtarō's journey of meditation) broadcast in February 2016 to commemorate the twentieth anniversary of Shiba's death, presenter Kagawa Teruyuki, who played Masaoka Shiki in Clouds Above the Hill, selected four main themes from Shiba's writings, particularly Kono kuni no katachi (The Shape of This Nation). Part I focused on Japan's status as an island nation and identified the curiosity of Japanese people and their mushisō no shisō 
(literally "thinking of non-thinking", i.e. an aversion to ideology) as explaining the absorption of new ideas and technology in the Meiji period that facilitated rapid modernisation. Part II focused on characteristics stemming from Japan's samurai heritage: a desire not to do things that cause shame, and public spirit. Shiba thought these tendencies that had sustained the "Meiji miracle" started to break down during the Hibiya riots of 1905 when protesters grew violent over the lack of war reparations following victory over Russia. In his view, the mistaken direction of the Shōwa period until Japan's defeat in 1945 stemmed from the military's subsequent usurpation of "supreme command" (tōsuiken), and their unchecked actions and provocation of incidents that Japan's leaders had to respond to post facto. NHK cited Shiba's comment, "There has not been a more stupid period [bakana jidai] in Japan's long history".

A key feature of the Shiba view, therefore, is the turning point of 1905. As Isoda notes, Shiba saw the early Shōwa years as a rogue period (kitai no jidai) when "Japan was not itself" (betsu no kuni datta) (Isoda 2016: 74-75). Alexander Bukh (2008: 104) argues that by making this contrast Shiba "saves the national history from criticism by shifting the responsibility for these years from 'Japan' as a nation to the military, considered to be outside of the normal 'Japan'". As such, while Shiba's writings eulogise Japanese history and culture, they defy simple characterisation as nationalism. First, although the Shiba view could be categorised as affirmative nationalism in justifying colonial expansion before 1905, he does not justify Japan's war aims and war conduct after 1905 . $^{2}$ Second, the Shiba view is also ambiguous or even contradictory regarding Korean colonial rule. For Shiba, “Japan was not itself” from 1910-1945, and he does not actively present a "revisionist" defence of Japan's colonial rule in Korea. ${ }^{3}$ But at the same time, as we shall see below, in Clouds Above the Hill he clearly asserts Japan's need, even right, to colonise the peninsula. Shiba also appears to lament the recklessness that resulted in the loss of Japan's Meiji period imperial gains, and not colonial rule itself. In short, the appropriateness of terming the Shiba view "nationalist" differs markedly for the pre- and post-1905 periods.

As already noted, the influence of Shiba's writings is enormous. Shimazu (2009: 273) credits Shiba with establishing "the orthodoxy for the post-1945 reconstruction of the 1904-05 war in popular cultural memory", and the Hankyoreh article by Gil Yu-Hyung cited above implies that it underpins the contemporary official narrative (as given in the 2015 Abe statement), too. However, it might be argued that Shiba did not so much create the "bright Meiji, reckless Showa" interpretation of history, but craft its most eloquent and powerful popular culture rendition. As Nakatsuka Akira notes, serialisation of Clouds Above the Hill in the Sankei Shimbun began in 1968, the centenary of the Meiji Restoration. At that time, Japan was in the midst of its post-war economic miracle, which evoked parallels with the Meiji miracle. This bright Meiji narrative infused the speeches of then Prime Minister Sato Eisaku and the views of the conservative elites that planned and carried out the centenary celebrations (Nakatsuka 2009: 14-17). Abe's 2015 statement, therefore, may not reflect the Shiba view so much as the conservative establishment view passed down by 
political and business leaders, including Abe's great uncle Satō Eisaku. From this perspective, Shiba's contribution in Clouds Above the Hill was to novelise and popularise the patriotic values of Japan's political establishment regarding the Meiji period.

\section{Consuming Shiba and his view of history}

Like many of Shiba's novels, Clouds Above the Hill was adapted for television. During his lifetime Shiba refused to allow the text to be dramatised because he feared its viewpoint would be mistaken for militarism (Nakatsuka 2009: 21). But, with the permission of his estate, Japan's public broadcaster NHK eventually made and broadcast the drama in three parts: five episodes in November/ December 2009, four in December 2010, and four in December 2011. Furthermore, from 1999 a process of machizukuri (community building) based around Clouds Above the Hill began in Matsuyama city, the home of the Akiyama brothers and Masaoka Shiki, involving the touristification of sites related to the novel (Hirano et al. 2008: 259).

The roles and impacts of Shiba's novel, the NHK drama adaptation, and related tourist sites are linked. The Shiba view of history finds its purest expression in the novel, where long sections of narration, heavily abridged in the drama, provide context. The drama also cuts dozens of figures who play a small part on the grand stage of history and concentrates on the relationships between the three protagonists. While NHK's adaptation of Shiba feels quite different from the novel in emphasising character study over grand historical tableau, the drama assumed significance in creating shared national culture. Each episode captured between 10 and 20 per cent of the viewing audience when first broadcast in 2009-2011, thus reaching several million citizens. The shared experience was enhanced by the media discussion, publication of related books and magazines, and tourism campaigns that routinely accompany the broadcast of major Japanese historical dramas.

The importance of the Clouds Above the Hill tourist sites is in connecting the novelisations and dramatisations of history, which lie in the realms of commercial activity and entertainment, with the realms of professional history, heritage, and official narratives. Monuments, museums, memorials, and other heritage sites are overseen by a range of professional custodians of the past, including historians, curators, researchers, tour guides, and local government officials. A major novel/ drama like Clouds Above the Hill forces professional custodians of the past to address semi-fictionalised renditions. Although these professional custodians might view novels and dramas as a hindrance to "accurate history", they might equally view them as an opportunity to raise interest and thereby disseminate serious historical research to a wider audience. However, whenever works of popular culture feature in, shape the message of, or even make economically viable a publicly funded heritage site, the messages of popular culture have entered the official narrative. Popular texts often first infuse official narratives in this way, as tourism resources managed by or with the involvement of local 
government that generate contents tourism, namely, people visiting sites related to the narratives, characters and locations of such works (Seaton et al. 2017).

Reading, watching and travelling the "Shiba view of history", therefore, reveals how literary texts, screen adaptations, and tourist sites create a mutually reinforcing network built around Shiba's writing that is further energised by discussion in documentaries, academic discourse, news and social media. When sufficient cultural power is generated, local government becomes involved in managing heritage. Such local practices are then only a short step away from reaching national policy.

\section{Clouds Above the Hill and its critics}

Clouds Above the Hill was originally published in 1,296 instalments, many of which depict a self-contained event or conversation in the manner of a film scene; others resemble short history lectures. This latter type contains examples of the Shiba view.

The following section from early in Volume I sets the narrative tone:

Small. There was perhaps no other country as small as Japan at the start of the new Meiji period. [...] This small nation, a rural backwater by world standards, had its first bloody struggle with a European civilisation in the Russo-Japanese War.

It managed somehow to win that struggle. The fruits of that victory were to be devoured and wasted by a later generation of Japanese, but the Japanese of that time used their utmost wisdom and courage, and took firm hold of their resultant good fortune.

(Shiba 2013a: 40)

Japan is presented as vulnerable, wise and courageous. Its adversary, meanwhile, is presented as large and aggressive: "Russia's ambition to invade the Far East became obvious around the middle of the Tokugawa period" (Shiba 2013a: 358). Shiba is critical of Russian conduct. "To see how bald-faced they were", he writes, "let us look at what happened between Russia and Japan [...]". He then recounts the Tsushima Incident of 1861:

On 12 April, a landing force went ashore near the guard station at Ōfunakoshi, shooting and killing the guard, a petty officer named Yasugorō, and taking captive his two fellow countrymen stationed there. After confiscating all the provisions and ammunition on hand, the Russians pushed on into the village and stole seven cows as well as gold and treasure before returning to the ship. Such bandit aggression was the Russian way.

(Shiba 2013a: 359)

This incident is notable for the parallels with the Unyo incident of 1875, when soldiers from a Japanese ship landed in a restricted area, were fired upon by the 


\section{Philip Seaton}

Korean shore battery, and then that was used as a pretext to kill over 30 Korean soldiers and loot the garrison (Kim 1999: 38). This incident was one of the pretexts for forcing the Kanghwa Treaty on Korea in 1876. The Unyo incident is not mentioned in Clouds Above the Hill. The combination of emotive criticism of Russian "bandit aggression" and omission of comparable actions by Japan is emblematic of Shiba's selective narration of history.

In many ways, the Sino-Japanese War and Russo-Japanese War were two stages of the same conflict. In the first war Japan wrestled control of Korea from China, and in the second Japan ended Russian ambitions there. Shiba says the following about Korea's geopolitical predicament:

Now we must touch on the cause of the [Sino-Japanese] war, which lay in Korea. This is not to say that Korea or the Koreans were in any way at fault. The only "fault" lay in a quirk of geography. For a peninsular nation to maintain its independence is never easy [...]

(Shiba 2013a: 205)

Korea's fate in this reading depends upon geography rather than the aggressive ambitions of surrounding powers. This theme is developed further in Volume II:

From the nineteenth century to the beginning of the twentieth, the world's countries and regions had only two paths open to them: to be colonised by another nation, or, if that was unacceptable, to create industries, gain the necessary military strength, and join the ranks of the imperialist powers. Now in a later age, we fantasise that the nations of that time should have adopted a policy of "neither invade nor be invaded" and should have focused only on the peace of mankind. We attempt to impose this fictive standard followed by these fantasy countries on the actual nations and international society of an earlier age, and then we use this fictive standard to judge the rights or wrongs of a nation's policy. This kind of thinking turns history into nothing more than clay to be used for making clay figurines in whatever shape one likes.

The world was at a different stage then. Having once chosen the path of autonomy through the Restoration, Japan had to preserve that autonomy, even if it was to the detriment of another country (Korea). At that historical stage, Japan had to fixate on Korea. If it had not done so, then not only Korea but Japan itself might have been swallowed up by imperial Russia. Such was the nature of national autonomy during this period.

(Shiba 2013b: 92)

This section's vigorous defence of Japanese actions regarding Korea is where Shiba sounds most like a nationalist apologist for Japan's empire.

These lengthy passages convey Shiba's view of history in Clouds Above the Hill. To summarise, the Sino-Japanese War and Russo-Japanese War are portrayed as righteous, victorious wars in which Japan adhered to the behavioural 
norms of the time. Through victory, Japan secured vital interests and enjoyed its finest military moments in the modern era.

But Shiba has many critics. Some, like Kanno Naoki writing in The National Institute for Defense Studies News, have censured Shiba from the perspective of military history and a more nationalistic position. Kanno objects to Shiba's assessment of the reasons for the outbreak of war and his negative depiction of General Nogi Maresuke. Most tellingly, he attacks Shiba's criticisms of 1930s nationalism as "too simplistic" (Kanno 2009: 34). Nevertheless, Kanno states: "Though one has repeatedly criticised Shiba thus far, one wouldn't like to assert that the novel should be brushed aside as a means of conveying history to future generations" (Kanno 2009: 35). Kanno's argument that novels bring to life history via realistic depictions of conversations and acts seems weak given his criticism of Shiba's historical accuracy. More likely, Kanno found Shiba's interpretation of the Meiji period more palatable than many other interpretations.

Such interpretations include those of Shiba's more progressive critics. Around the time that the drama was released, several books targeted not only Shiba but also NHK and often note omissions of incidents that portray Japan in a negative light. Nakatsuka et al. (2010: 172), for example, note that the Port Arthur Massacre of November 1894, in which Chinese sources claim 10,000 people died, is ignored in the novels and that NHK only addressed it in a guidebook accompanying the series. ${ }^{4}$ Indeed, much of their criticism targets NHK. Even though the drama focuses less on military history and omits much of Shiba's more strident narration, Nakatsuka et al. criticise Japan's public broadcaster for historical inaccuracy, for making the drama at a sensitive time in Korea-Japan relations (centenary of the annexation), and for going against Shiba's own wishes in producing the drama (ibid.: 180-181).

The Ehime Society Supporting Textbook Trials and the Society to Consider the Problem of the Clouds Above the Hill Museum also sent an open letter of protest to NHK. Both organisations raised similar criticisms but are significant as groups opposed to the touristification of local Clouds Above the Hill sites. They noted how NHK's drama in effect supported the views of the Japanese Society for History Textbook Reform, a nationalist group that has produced a controversial textbook available for use in Japanese middle schools since 2002 (Takai 2010: 189). NHK responded that Shiba's work did not glorify war and that they wanted to convey the energy of the period on a grand scale (ibid.: 202).

However, the Shiba view of history certainly had an impact upon Fujioka Nobukatsu, the ideological father of the "liberalist view of history" (jiyūshugi shikan) and a key member of the Society. In What is the Liberalist View of History?, Fujioka states that reading Clouds Above the Hill showed him a middle way between what he called the "Asian liberation theory" (i.e. nationalism) and the "Tokyo trials views" (i.e. progressivism) of the Asia-Pacific War. He presents his "liberalist view of history" as effectively identical to Shiba's views and summarises them as a combination of "healthy" (kenzenna) nationalism, realism, a rejection of ideology, and anti-bureaucratism (Fujioka 1997: 138-41). 
This admission by Fujioka indicates that the textbook controversies of the late 1990s and 2000s were heavily inspired by Shiba, although he had died just before the Japanese Society for History Textbook Reform was launched. The approval of their textbook in 2001 had major diplomatic repercussions in East Asia for the next decade, particularly in Korea and China. While this textbook did not present the official narrative of national government (and was subject to many revisions before approval), as a government-approved textbook influenced by Shiba's views, it nonetheless poisoned Korea-Japan relations in 2001.

Despite his professed rejection of the Asian liberation theory, within a few years of his tribute to Shiba's influence on his thinking, Fujioka had slipped to the nationalistic extremes of Japanese war debates and was engaging in Nanjing Massacre denial. Ultimately, the views of Fujioka and Shiba on the Asia-Pacific War differed substantially. However, the question remains whether Shiba's views of the 1930s and 1940s were determined by regret for the damage the war caused Japan or genuine belief that the war and imperialism were wrong.

\section{Clouds Above the Hill as heritage}

Shiba Ryōtarō occupies an important position in Japan's tourism history. He wrote about his extensive travels and conducted fieldwork at heritage sites while researching his novels. In doing so, he crafted uplifting narratives that sustain or even made possible tourist sites today. The impact of his writings makes it appropriate to consider him a father of heritage tourism in contemporary Japan.

Tourism in Matsuyama in Ehime prefecture on Shikoku exemplifies Shiba's influence. Clouds Above the Hill established Matsuyama as an important site related to the Russo-Japanese War. Under Mayor Nakamura Tokihiro, who was both a fan of the novel and supporter of the liberalist view of history, the city was divided into zones and designated a field museum. ${ }^{5}$ Seven billion yen (supplemented by 2.8 billion yen from national government) was allocated to building the Clouds Above the Hill Museum and improving infrastructure in the nearby Matsuyama Castle Ropeway area and the Dōgo hot spring area. ${ }^{6}$ The museum, designed by world-famous architect Ando Tadao (who also drew up the plans for the Shiba Memorial Museum in Osaka), opened in 2007. A few years earlier, the Akiyama Brothers' Birthplace Museum was reconstructed and opened in 2005 (Ehime shimbunsha 2009: 14-17). Fortuitously for Matsuyama (and likely with its active lobbying), NHK decided in 2003 to dramatise Clouds Above the Hill. The key sites relating to the novel were ready to welcome visitors inspired by the broadcast of the first part of the drama in 2009 .

Tourism statistics indicate that the machizukuri programme has had a significant impact on the city. The Clouds Above the Hill Museum attracted around 125,000 visitors a year during its first decade, with over 200,000 visiting annually in the years of the drama's broadcast. ${ }^{7}$ These enhancements contributed to a rise in the base level of tourism in Matsuyama by about 600,000 visitors per year from the plateau of around five million in the early 2000 s to a new plateau nearer six million in the 2010s. This clear success story for the city vindicates its 
decision to utilise Shiba's novel as a tourism resource. The city was also awarded the third Minister for Land, Infrastructure, Transport and Tourism Planning Prize in 2007.

Given that Clouds Above the Hill is now central to municipal branding, that the novel depicts Matsuyama as a vibrant centre of Meiji period modernisation, and that hotels, restaurants and retailers today benefit from the Shiba effect, little incentive exists locally to challenge Shiba and his view of history. Discrediting the Shiba view would not only discredit a view of history but undermine a tourism resource that sustains a local brand, business, and employment. A touristification process like the one seen in Matsuyama, therefore, creates diverse stakeholders with a vested interest in promoting a particular narrative. What matters more than the narrative's accuracy is its usability: cultural producers easily adapt the Shiba view as uplifting and inspiring entertainment; community leaders derive a positive identity from association with such narratives; and tourism operators treat them as a resource from which to make profits. Where all these benefits exist, politicians may gain public support by promoting the heritage. Local politicians in Matsuyama may focus more on local business, but national(istic) politicians like Abe Shinzo can find in the Shiba view an uplifting alternative to progressive intellectual narratives of aggressive Japanese expansionism in the Meiji and early Showa periods.

\section{Conclusion}

The analysis of the Shiba view of history, its articulation in Clouds Above the $H i l l$, the interconnected impacts of the novel, drama and tourist sites, and the relationship between a successful work of popular culture and official narratives together suggest the following conclusions.

First, the Shiba view of history (Shiba shikan) draws much attention in academic and literary circles within Japan. It has also been credited with influencing or even underpinning the official government narrative. It might be more appropriate to say that the view grew out of existing conservative narratives, such as those expressed during the centenary of the Meiji Restoration. But, the narrative of a bright Meiji period (to 1905), followed by the mistakes of the early Showa period (to 1945), followed by the post-war miracle - in other words, two positive periods sandwiching an aberration - is now firmly associated with Shiba. The view justifies Japanese imperialism in light of the era's norms but remains critical of war year mistakes. In 2015, something close to this position became the official government stance, overturning two decades of more progressive statements made by prime ministers from Hosokawa Morihiro to Kan Naoto.

Second, although the Shiba view does not offer the most nationalistic interpretation of Japan's modern history, and indeed it has been criticised in nationalist circles, it nevertheless presents a view largely incompatible with Korea-Japan reconciliation. The wars that paved the way for Japan's annexation of the Korean peninsula are depicted as part of a golden, energetic age. For Koreans, the Meiji period began with Japan opening Korea via gunboat diplomacy, included two 
major wars fought in or close to Korean territory, and ended with Korea's annexation. However bright this period was for Japan, virtually no Korean, North or South, would consider it so for Korea. Overall, as long as the Shiba view and more generally conservative Japanese views of this era remain powerful, the work of this man dubbed a "national author" (kokumin sakka) will impede reconciliation between Japan and the two Koreas.

Third, the Shiba view exemplifies how popular culture may influence official narratives, and ultimately diplomatic relations. By tracing how the narratives within Clouds Above the Hill went from little-known local history, to highly successful work of popular culture, heritage sustained by local government, and historical interpretation affecting national debate (including governmentapproved textbooks), the discussion in this chapter has indicated how powerful works of popular culture intertwine with politics.

Fourth, when a popular text achieves sufficient power to influence official narratives, it signals that the work is also embedded in popular consciousness. Political positions might change quickly via an about-face in policy, but a cultural artefact can remain embedded much longer. The Japanese official narrative shifted towards a more "cosmopolitan" (Saito 2017) position regarding Japan's colonial rule of Korea from the Murayama statement of 1995 to the Kan statement of 2010. However, that shift has not outlasted the Shiba view of history. When Clouds Above the Hill first appeared in 1968, the Shiba view was close to the official narrative, and the 2015 Abe statement returns that official position more closely to the Shiba view than at any point since the 1980 s.

Peter Duus (2017: 11) has written:

Historical memory is long, especially if it is aggrieved memory. While studying Meiji expansion on the Korean peninsula, I was surprised to learn that even in the 1890s, Korean peasants were singing songs about the defeat of the Hideyoshi invasion three centuries before.

Korean memories remain long and aggrieved about the colonial period, too, which is why the Shiba view and conservative justifications of Japanese empire remain such a barrier to reconciliation today.

But historical memory may also run deep, especially if it underpins a positive vision of the past that affirms collective identity and sustains economic activity in the present. Herein lie the roots of Shiba's enduring popularity in Japan and his vision of the bright Meiji period, whose primary achievement was not colonising Korea, but modernisation that allowed Japan to avoid being colonised by the West. These were the clouds - namely Western civilisation as an object of both fear and admiration - that Japanese people saw above the large hill of Meiji period modernisation that they had to climb (Hirano et al. 2008: 258). With the Shiba view, therefore, as with all cultural practices, understanding the meanings and resonances for others of the same work of popular culture is a prerequisite for that work to aid, or at least not hinder, a reconciliation process. 


\section{Notes}

1 The museum is run by the Shiba Foundation. Their website (www.shibazaidan.or.jp) contains a complete list of his works.

2 "Affirmative nationalism" here is used to refer to arguments such as Japan was fighting for the "liberation of Asia", or denial of atrocities (particularly Nanjing Massacre denial).

3 Regarding colonialism, revisionists typically make the following arguments: Korean nationalism prevents a fair assessment of the achievements of colonial rule, particularly modernisation and advances in education and infrastructure; Korean leaders prior to Japanese colonial rule were corrupt and unpopular; and Japanese colonialism was more benign than Western colonialism. For an example in English, see Akita and Palmer (2015).

4 See Shiba (2013a: 238-240) for the section about the fall of Port Arthur with no discussion of any massacres.

5 The Field Museum concept is outlined on the city homepage (Matsuyama City n.d.).

6 Interview with Ishikawa Jun at Matsuyama City Hall, Clouds Above the Hill Machizukuri Division, 18 May 2017.

7 As this chapter went to press, tourism levels in Japan were collapsing because of the coronavirus pandemic. This discussion relates to the period up to 2019.

\section{References}

Abe, Shinzo. 2015. "Statement by Prime Minister Shinzo Abe", 14 August. japan.kantei. go.jp/97_abe/statement/201508/0814statement.html.

Akita, George and Brandon Palmer. 2015. The Japanese Colonial Legacy in Korea, 1910-1945. Portland: MerwinAsia.

Bukh, Alexander. 2008. "Historical Memory and Shiba Ryōtarō: Remembering Russia, creating Japan", in The Power of Memory in Modern Japan, edited by Sven Saaler and Wolfgang Schwentker. Folkestone: Global Oriental: 96-115.

Duus, Peter. 2017. "Introduction: History wars in post-war East Asia, 1945-2014", in "History Wars" and Reconciliation in Japan and Korea, edited by Michael Lewis. New York: Palgrave Macmillan: 1-16.

Ehime shimbunsha [Ehime newspaper]. 2009. “'Saka no ue no kumo' no Matsuyama o aruku [Walking the Matsuyama of 'Clouds Above the Hill']". Matsuyama: Ehime shimbunsha.

Fujioka, Nobukatsu. 1997. Jiyūshugi shikan to wa nani ka. Kyōkasho ga oshienai rekishi no mikata [What is the Liberalist View of History? Views of history not taught in textbooks]. Tokyo: PHP Bunko.

Gil, Yun-Hyung. 2015. "The Historical Tale behind Abe's Statement”. The Hankyoreh, 16 August. english.hani.co.kr/arti/english_edition/e_international/704735.html.

Hirano, Tatsushi, Sven Saaler and Stefan Säbel. 2008. "Recent Developments in the Representation of National Memory and Local Identities: The politics of memory in Tsushima, Matsuyama, and Maizuru". Japanstudien [Contemporary Japan] 20: 247-77.

Isoda, Michifumi. 2016. 100-fun no meicho. Shiba Ryōtarō supesharu [Classic books in 100 minutes. Shiba Ryōtarō special]. Tokyo: NHK Shuppan.

Isoda, Michifumi. 2017. "Shiba Ryōtarō" de manabu Nihonshi [Learning Japanese history via Shiba Ryōtarō]. Tokyo: NHK Shuppan Shinsho.

Kan, Naoto. 2010. "Statement by Prime Minister Naoto Kan", 10 August. japan.kantei. go.jp/kan/statement/201008/10danwa_e.html. 


\section{Philip Seaton}

Kanno, Naoki. 2009. "Ryotaro Shiba's Clouds Above the Hill (Saka no ue no kumo) and the Russo-Japanese War: from a researcher's perspective". National Institute for Defense Studies News, 137: 31-35. www.nids.mod.go.jp/english/publication/briefing/ pdf/2010/137.pdf.

Keene, Donald. 2003. 5 Modern Japanese Novelists. New York: Columbia University Press.

Kim, Key-Hiuk. 1999. Opening of Korea: A Confucian response to the Western impact. Seoul: Institute for Modern Korean Studies, Yonsei University.

Matsuyama City. n.d.: “'Saka no ue no kumo’ no machizukuri shōkai zasshi” [Pamphlet introducing Clouds Above the Hill community building]. www.city.matsuyama.ehime. $\mathrm{jp} /$ shisei/machizukuri/sakanoue/field_museum_map.html.

Nakatsuka, Akira. 2009. Shiba Ryōtarō no rekishikan. Sono "Chōsenkan" to "Meiji eikōron" o tou [The Shiba View of History: Questioning his "Views of Korea" and the "Bright Meiji Theory"]. Tokyo: Kōbunken.

Nakatsuka, Akira, Junosuke Yasukawa and Satoshi Daigo. 2010. NHK dorama "Saka no ue no kumo" no rekishi ninshiki o tou. Nisshin sensō no kyokō to shinjitsu [Questioning the historical consciousness of NHK's drama Clouds Above the Hill: Fact and fiction regarding the Sino-Japanese War]. Tokyo: Kōbunken.

Podoler, Guy and Michael Robinson. 2007. "On the Confluence of History and Memory: The significance of the war for Korea", in The Impact of the Russo-Japanese War, edited by Rotem Kowner. Abingdon: Routledge: 183-198.

Saito, Hiro. 2017. The History Problem: The politics of war commemoration in East Asia. Honolulu: University of Hawai'i Press.

Seaton, Philip, Takayoshi Yamamura, Akiko Sugawa-Shimada, and Kyungjae Jang. 2017. Contents Tourism in Japan: Pilgrimages to "sacred sites" of popular culture. Amherst: Cambria Press.

Shiba, Ryōtarō. 2013a. Clouds Above the Hill. A Historical Novel of the Russo-Japanese War. Volume I, translated by Juliet Winters Carpenter and Paul McCarthy, edited by Phyllis Birnbaum. Abingdon: Routledge.

Shiba, Ryōtarō. 2013b. Clouds Above the Hill. A Historical Novel of the Russo-Japanese War. Volume II, translated by Juliet Winters Carpenter and Paul McCarthy, edited by Phyllis Birnbaum. Abingdon: Routledge.

Shimazu, Naoko. 2009. Japanese Society at War: Death, memory and the Russo-Japanese War. Cambridge: Cambridge University Press.

Takai, Hiroyuki. 2010. Gobyū darake no "Saka no ue no kumo". Meiji nihon o bika suru Shiba Ryōtarō no sajutsu [Error-strewn Clouds Above the Hill. Shiba Ryōtarō's swindle of beautifying Meiji Japan]. Tokyo: Gōdō Shuppan. 


\section{Part II}

\section{Reimagining Japan-Korea relations in film}




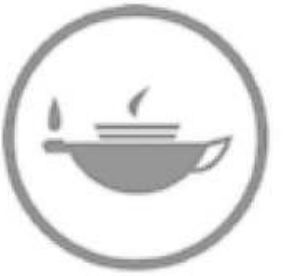

Taylor \& Francis Taylor \& Francis Group http://taylorandfrancis.com 


\title{
4 Remembering to reset \\ Representations of the colonial era in recent Korean films
}

\author{
Hee-seung Irene Lee
}

\section{Introduction: colonial memories in revision}

As Hayden White (1996: 19) explains, the affective spaces that modern visual media create for the incessant attempts to remember the past "blur the distinction between fact and fiction" by envisioning, dramatising and fictionalising historical events to the extent that historical accuracy and objectivity lose significance for audiences of those textualised memories. Through imaginative historymaking processes on screen, the stream of documentaries, period films and historical dramas in contemporary media culture not only reconstruct the past but also constantly revise individuals' relation to shared memories of historical experiences. In the case of South Korea, Frances Gateward (2007: 194) observes, "this fixation with history and memory is indicative of what I would characterise as the preeminent project of contemporary Korean cinema, the determination of a national identity". Although such a "fixation with history and memory" has been ubiquitous in Korean film for decades, a conspicuous shift occurred in the 2000s in South Korean films' representation of the colonial past, as Jinsoo An indicates in Parameters of Disavowal: Colonial Representation in South Korea Cinema, a detailed study of films from 1945 through the 1970s that treated the Japanese Occupation. For An, the films of the first decade of the new millennium "offer a different interpretative possibility with respect to the configuration of colonial space and meaning of the popular culture" (2018: 128). Apparently, their revisionist approaches attempt to move away from the postcolonial preoccupation with nationalist sentiment and propagandist intent under the rigid Cold War ideology of the previous decades. However, these colonial-themed films of the early 2000s failed to capture the attention of domestic audiences and critics due to structural, aesthetic and thematic limitations that, An comments, result from the films' ambitious rush to transcend such long-established nationalist conventions "too easily".

Differently from the lukewarm reception met by these earlier films, the most recent cinematic images of Korea under the yoke of Imperial Japan have aroused tremendous interest critically and commercially. In the short period between 2015 and 2017, a torrent of South Korean films dealing with the Japanese Occupation was released, making the presence of colonial themes in domestic films 
prominent. For instance, Assassination (2015), portraying the armed resistance fighters of the Heroic Corps, sold over 10 million tickets and anticipated a group of colonial period films vying for national audiences. This set of films featuring colonial Korea has not only offered diverse narratives, characters and perspectives that revise prevailing South Korean memories of colonial experience and its legacy, but also kept a careful balance with commercial considerations by envisaging renovations of these memories within the generic conventions of commercial cinema. This chapter will examine the distinctive recent rise of film industry attention to colonial experience as a reflection of an emergent demand for a refreshed cinematic memory of not only the humiliation, frustration, and pain of the period under the old banner of nationalism, but also renewed curiosity about and excitement over budding modernity in the early twentieth century. Of particular interest is how recent colonial-themed films revamp the image of pro-Japanese collaborators to address moral and ethical dilemmas that the modern world imposed on colonial subjects - challenging choices between the mother country and the new colonial state as well as between moral obligation and personal desire. The following discussion focuses on Assassination and The Age of Shadows (2016), which feature resistance activists who are pushed to a precarious border between patriot and traitor. Both films fictionalise a scarcely recognised real history of the Heroic Corps (Üiyoltan), a group of militant resistance fighters who carried out bombing attacks on the Japanese colonial headquarters in the 1920s. The close reading of the two films presented here will suggest that these recent treatments of the colonial past attempt to reconfigure memory of the era so that it can be recollected and experienced as a turbulent and confusing period in the birth of modernity in Korea.

As Rebecca Saunders (2007: 2) suggests, modernity is a concept transcending the spatial-temporal containment of historiography best grasped via a cluster of socioeconomic and political conditions such as "industrialisation, capitalism, and urbanisation; a large-scale market economy ... and a complex division of labour and secular political power, the nation state, liberal democracy, and the interstate system". These external conditions induce "a body of experiences and moods supposed to epitomise modernity, such as perpetual change, uncertainty, alienation, or anomie". This conceptualisation of modernity thus allows a reading of a hidden connection between the onscreen memory of colonial Korea in Assassination and The Age of Shadows and contemporary Korean conditions. In both eras, Korea seems under the enormous pressure of rapid, discursive changes towards a more affluent, more democratic, yet highly polarised Korea entangled with the interests of surrounding superpowers. In other words, these colonial period films offer an opportunity for a contemporary expression of uncertainty and alienation through the recollection of colonial Korea's confrontation with a vortex of overwhelming modernity. Different from the treatment of self-assured patriots in preceding colonial-themed films, the two films render Koreans, living through the formative years of the nation, as modern subjects perplexed by the clash between traditional values and modern conditions and, thus, split between loyalty to the lost nation and desires to follow new, modern 
ideas and trends. Such confusion may have been a widespread by-product of the colonial experience, yet the specific contours of Korea's chaotic encounter with modernity via colonisation almost certainly intensified this disorientation. Based on the socioeconomic, political and psychological traits embedded in the concept of modernity, these films have surfaced in the middle of the 2010s and their filmic re-enactments of colonial memory imply underlying yet noteworthy connections between the two eras. That is, while the recent films depict Korea under Japanese rule, contemporary Korean audiences' welcoming and empathetic perception of the past on screen indicates that they may discover therein the abovementioned modern conditions, a new modality of which they are experiencing in the 2010 s.

\section{Increased thematic, generic and aesthetic diversity of colonial memories}

The mid-2010s' outburst of films set in the colonial period is striking. The year 2015 also marks a visible shift in the commercial success of such films: until then, the frequent films with a colonial era setting had little notable box-office success in the domestic market, with a few exceptions such as Im Kwon-taek's General's Son (1990). In 2015, however, three such films were listed in the year's top 50 Korean films, with Assassination second most popular. Korean Film Council annual box-office statistics show that the trend continued in 2016, with seven colonial-themed films among those with the highest box-office receipts, and five in 2017.

A brief overview of these films reveals a constellation of generic features, themes and characterisation of colonial Koreans. Assassination (Amsal 2015, dir. Choi Dong-hoon [Ch'oe Tonghun]) is a spectacular action-adventure representing guerrilla operations by freedom fighters of the Heroic Corps to assassinate a proJapanese collaborator and a Japanese military leader in 1933 Seoul. The Silenced (Kyŏngsŏnghakkyo: Sarajin Sonyŏdŭl 2015) takes the form of high school horror, a popular and elaborate genre in both Korean and Japanese commercial cinema. The film implicitly connects Japan's systematic abuse of Korean girls in a boarding school with political debate over the sexual exploitation of Korean "comfort women" by the Imperial Japanese Army during the Asia-Pacific War (1941-1945). The Tiger: An Old Hunter's Tale (Taeho 2015) is a nostalgic recollection of the pre-modern world as a pristine reservoir of Korean spirits, disturbed and destroyed by the invasion of Imperial Japan. The film delineates the struggle of a Korean hunter who chases the elusive last tiger in the wild to protect this sacred creature from a ruthless Japanese general who seeks to violate the spirit of Korea by hunting its tigers into extinction. Dongju: The Portrait of a Poet (Tongju 2016) is a biopic about renowned poet Yun Tongju, along with his cousin Song Monggyu, who participated in the Korean Independence Movement. Shot in black and white, the film portrays how young Korean intellectuals were torn between yearning for artistic achievement and the demand for Korea's independence until they faced early deaths in Japanese prisons for their activism. 
There are a group of films which particularly focus on the female experience of the colonial past. Spirits' Homecoming (Kwihyang 2016) directly confronts the comfort women issue. The film follows the trauma experienced by girls forced into sexual slavery and the lingering pain felt by survivors in liberated Korea; famously funded by citizen contributions, this film took 13 years to complete. The melodrama Love, Lies (Haewŏrhwa 2016) unfolds a love triangle between a male composer and two young kisaeng who wish to become singers during the turbulent final years of the occupation. The Handmaiden (Agassi 2016) is a costume drama dealing with the same-sex relationship between a Japanese heiress and her Korean servant. Their desire to break free from the rigid social and sexual orders of Imperial Japan and Confucian Korea adds nuance to a subtext of political and cultural desire for liberation from colonialism. The Last Princess (Tǒk'ye Ongju 2016) is loosely based on the story of Princess Tŏk'ye, who was taken to Japan as a hostage and later married a Japanese aristocrat. The film lies at the juncture of biopic, melodrama and costume drama and dramatises her life from youth in the royal palace to her return to South Korea in the 1960s, elderly, deserted and mentally disturbed.

Masculine perspectives and experiences are also foregrounded in several films. The Age of Shadows (Miljöng 2016, dir. Kim Ji-wun [Kim Chiun]), which I consider in detail below, is an espionage thriller whose narrative follows in parallel the storyline of the Heroic Corps bringing explosives from Shanghai to Seoul and that of a seemingly traitorous ethnic Korean police captain, Yi Chŏngch'ul. While working for the Japanese police, Yi infiltrates the resistance group for information and functions as an enigmatic knot between the two sides. Anarchist from Colony (Pak Yŏl 2017) is another biopic, which treats the famous 1920s Imperial Japanese court trial of anarchist and independence activist Pak Yŏl and his Japanese partner Fumiko. The blockbuster epic The Battleship Island (Kunhamdo 2017), which had one of the biggest budgets ever for a Korean film, depicts the desperate escape of Koreans conscripted to a labour camp on a small Japanese island. The above list, in highlighting the generic breadth, thematic diversity, scale of production and eager audience response to these recent films, urges examination of why such films surged in the mid-2010s.

As mentioned, a smaller cohort of films in the first decade of the new millennium dealt with the same historical period, including Anarchists (2000), 2009: Lost Memories (2002), YMCA Baseball Team (2002), Blue Swallow (2005), Epitaph (2007), Radio Dayz (2008) and Modern Boy (2008). Yet, these cinematic visions of the nation's degraded past neither drew critical attention nor earned great profit. Despite their lacklustre reception, however, they point to experimentation with the portrayal of the beginnings of modernity in Korea and deviate from the predictable binary caricature of Korea as victim and Imperial Japan as villain. I suggest that these films' attempts to revamp cultural memories of historical experience opened the floodgates for the later spate of films.

For instance, Anarchists (2000) delves into ideological dynamics within the Korean Independence Movement, and the film's thematic focus differs from a long tradition of valorising independence activists as self-effacing patriots 
uniformly working for a great cause. Films like YMCA Baseball Team (2002) and Radio Dayz (2008) consider Western modernity's arrival in an Eastern "hermit nation" under a rigid, centuries-old Confucian order by foregrounding baseball and radio, respectively. Blue Swallow (2005) became a topic of public debate and media coverage upon release in 2005. The film featured a star cast, high production values, and a progressive approach resisting Korea's maleoriented biopic genre of colonial representation. Its protagonist is the pioneering Korean aviatrix, Pak Kyŏngwŏn, who, far from being a helpless victim, ambitiously realises her childhood dream of flying. However, Korean audiences rejected the film's depiction of Park because historians had identified her as a collaborator whose daring aviating exploits celebrated the Imperial Japanese army, a revelation that led to the film's commercial and critical failure.

Despite attempts to innovate in cinematic expression of colonial Koreans, most of these earlier films relied on familiar plots of oppression, suffering and heroic resistance by narrative's end, even at the cost of diverse interests in colonial experience and initial openness to multivalent interpretations. Modern Boy (2008) showcases this disconcerting co-existence of innovative cinematic treatment of colonial modernity and a well-preserved nationalistic ending. Much of the film's plot centres on a young man whose pleasure-seeking lifestyle and romantic pursuits move the mood of the film away from the heavy clouds of colonial resentment. The glamorous CGI restoration of 1930s Seoul is remarkably detailed. At first, this reconstruction of colonial modernity sets the film apart from the usual internalised shame and humiliation over the forsaken nation. Modern Boy "remembers" that curious individuals embraced new trends in a lively, multicultural urban space. The protagonist is a naïve, light-hearted playboy who starts his day with coffee, savours jazz and works at the Government General of Korea. He is individualistic rather than consciously traitorous and the main plot is inadvertently driven by his infatuation with a mysterious cabaret singer who is a freedom fighter in disguise. As Kang (2015: 37) discusses, the film's narrative spirals downward in film noir style, and the hero's savvy modernity and cheeky romance is absorbed into "the oppressive colonial reality concealed behind the glamorous architecture in modern Kyung-sung [Kyŏngsŏng]": he is drawn into the resistance as he becomes aware of the brutal binary between coloniser and colonised. Although the hero's fall clashes with the film's flamboyant portrayal of modern city life, this disjunction produces a realistically resonating portrait of 1930s' Korea and its people. As suggested above, these earlier attempts to revisit colonial Korea and recast history from fresh angles usher in the more engaging representations of Koreans at a befuddling historical crossroads in the mid-2010s films.

\section{New portraits of pro-Japanese collaborators}

In one sense, Assassination and The Age of Shadows offer spectacular renditions of resistance fighters and their operations against Imperial Japan with the selfevident nationalist orientation. Such treatments of the independence movement 
as involving one action-packed "mission impossible" after another against Japanese rule captures the social and cultural modality of mid-2010s Korea. Interestingly, a year before Assassination's box-office success, the domestic film market saw the highest-grossing film of all time, The Admiral: Roaring Currents (Myŏngryang 2014), with over 17 million tickets sold. The film tells the story of Admiral Yi Sunshin, who fought against the Japanese invasions of 1592-1598, and, in one of Korea's most celebrated battles, defeated over 300 Japanese war vessels with the 13 ships remaining under his command. The film's success encouraged a series of financially risky productions visualising colonial Korea, whose costly screen materialisations had been shunned after the previous decade's failures. The Admiral: Roaring Currents also helped persuade filmmakers to shift recollection of Korea's historical relationship to Japan from passive endurance to active resistance. Assassination and The Age of Shadows manifest this change towards imagining Korean victories over Japan. This confrontational engagement with the past has been fuelled by heightened public interest in political, diplomatic disputes around the naming of East Sea/Sea of Japan, the territorial sovereignty of Dokdo/Takeshima, and especially "the new 'urgency' on the two governments" to settle the comfort women issue (Chua 2017: 16).

Assassination and The Age of Shadows share not only imagination of Korean resistance but elaborate characterisation of pro-Japanese collaborators, which likely derives from increased public interest in the unresolved problem of how to remember Koreans who chose to work for the occupation government. In the 2012 presidential campaign, Lee Jung-hee [Yi Chŏnghŭi], the candidate from the Integrated Progressive Party, referred to the conservative Grand National Party's candidate Park Geun-hye, who later was elected, as the daughter of national traitor Takagi Masao, the Japanese name of former president and dictator Park Chung-hee. Lee's climactic act of naming Park Chung-hee a traitor/ collaborator in a nationally broadcast debate endorsed the pervasive, if unwarranted, rumour that as a young elite officer serving the Imperial Japanese Army in the early 1940s, Park carried out operations to eradicate Korean independence fighters in Manchuria. Such a bold enunciation stirred deep-seated antagonism against collaborators and animated debate over how to bring justice to historical oblivion.

Furthermore, the public's dissatisfaction with consecutive right-wing administrations from 2008 until 2016 began to merge with demand for inquiry into collaborators. The recurrence of this theme may be likened to a Freudian return of the repressed. The merger of historical antagonism and contemporary discontent is rooted in the repressed resentment buried under the postcolonial construction of South Korean national identity. In the aftermath of Liberation, many pro-Japanese collaborators in the South, unlike those immediately trialled, exiled or executed in the North, maintained control with US military government support. Moreover, their descendants, like Park Geun-hye, are widely believed to have occupied the most privileged positions in South Korea for decades. Their apparent advantages have fuelled public resentment in the 2010s as the nation's economic growth slowed and inequality deepened. Above all, the public felt an 
erosion of democratic gains made through self-sacrificing student activism and wide civil participation, culminated in the 1987 Democratic Uprising that finally brought down the military dictatorship of almost three decades. With the articulation of anger at historical injustice on the surface of contemporary media discourse, many openly questioned whether pro-Japanese collaborators had been appropriately dealt with. As a response, Assassination and The Age of Shadows present a multifaceted image of collaborators in their imagination of the colonial past.

Drawing on Kristeva's appropriation of the Freudian Uncanny in Strangers to Ourselves, Kang Kyoung-lae addresses South Korean cinema's attention to collaborators. Her apt interpretation of Kristeva treats this attention as revealing not so much a desire to exclude disgraceful blots upon South Korean nationalism as a desire to establish a more comprehensive colonial history and, hence, reset the boundaries of contemporary South Korean society. Kang writes:

The recent reemergence of pro-Japanese collaborators in this sense indexes contemporary South Koreans' reflecting themselves upon the others, the repressed and shameful group of people in the colonial past - the concealed colonial past - who had long been treated as excluded Others but are newly understood as forgotten parts of Korean modernity. One may say that the recent return of the concealed Other creates a locus in which contemporary Koreans can reflect Korean colonial modernity and contemporary South Korean society as the extension of the modern era.

(Kang 2016: 232)

In the same vein, Assassination and The Age of Shadows deal with heightened attention to pro-Japanese collaborators in the 2010s and try to incorporate vivid images of them into the tapestry of Korea's colonial modernity, which has been extended to embrace the public interests and demands of contemporary Korean society.

\section{"We need to let them know that we're still fighting"}

Before analysing the renewed position of remembering colonial Korea in Assassination and The Age of Shadows in detail, it is necessary to consider how screen images can affect individual and collective memory of the past and, consequently, a sense of national identity. Earlier I cited White's explanation of visual media's capacity to shape, contest, negotiate and shift memories of the past. Similarly, Elisabeth Bronfen (2006: 23) suggests "we need the imaginary because it is here that we make sense of the world by producing coherent narratives, which in turn serve as the basis for any sense of community and political action". Drawing on the Lacanian concept of the mirror stage as a formative process of constructing the sense of a unified and coherent self (Lacan 2006), Silverman (1996) endorses the visual medium's power to address historical traumas that are re-mastered through fantasy to build elements that normalise 
our visual memory of the past. Strupples (2003: 128) also pays particular attention to the psychic mechanism through which visual representations of the past become "recollections rather than imaginings". However, the ostensibly private act of remembering always involves more than a personal act. Kuhn (2010: 1) affirms that "remembering is institutionalized through cultural means" to materialise the past, and this materialised image of cultural memory and constant acts of remembering in turn "may reference and construct a commonly shared past, and thus also communities of remembering". In understanding the two films' attempt to create a multidimensional portrait of freedom fighters and collaborators, the outlined theoretical approaches suggest the cinematic power of not only visually representing but also materialising, normalising and institutionalising memories of the past. As I observed above, Korean cinema has been diligently envisioning the colonial past and offering those memories both as a foundation of collective identity to a community of remembering and as grounds for the renewal of national, historical and cultural identity.

In this sense, Assassination and The Age of Shadows offer a shared site for remembering the past in ways that allow their renewed imaginary of colonial Korea to repair historical traumas, rework normalised memories of suffering under the Japanese rule, and reconstruct a communal vision of the past that constitutes a more empowered identity. The two films epitomise recent colonial films with their easily discernible generic orientations, accessible and entertaining through their innovative imagination of Korean independent fighters. The films also highlight collaborators as part and parcel of colonial history. Their narratives reflect the emerging need for a collective memory supporting historical agency and foreground aggressive independence movement and spectacular guerrilla attacks against not only the Japanese authorities but also pro-Japanese collaborators. In their attempts to fill a fissure in memories of the dilemmas experienced by colonial subjects, the films offer convincing portraits of Koreans caught between loyalty to Korean identity and desire to embrace the modernising socioeconomic structure of colonial Korea.

Nationalist sentimentality in association with nostalgia and melancholia has been embedded in Korean cinema since Na Woon-gyu's 1926 hit Arirang. The film addresses the psychological scars left in colonial Koreans "via the melodramatic imagining of the madness caused by colonial rule" (Taylor-Jones 2017: 33 ), expressing them in the figure of a young Korean man who goes insane. Ever since, Korean cinematic representation of internalised colonial pain and trauma has constructed memory of the Japanese Occupation as a period when the country lost its way on the road to building a modern state. However, contemporary films refuse such stereotypical representations and seek out a position that moves beyond self-victimisation. Audiences with no experience of defeat and subjection appear to demand a new reference for constructing Korean identity, especially after their pride in the emergence of Hallyu, as the nation's popular culture rose as a global trendsetter. Assassination and The Age of Shadows respond to this urge to remember the country's confrontation with modernity in the early twentieth century through the image of heroic resistance 
fighters. Such renewed cinematic recollection of colonial subjects allows contemporary audiences to identify with freedom fighters who move Korea closer to independence while embodying the stylish flair of modernity, often represented through fashionable outfits, candid expressions in dialogues and skilful handling of then new technologies, such as cars and machine guns. In addition, those resistance fighters' railway journeys from their headquarters in Shanghai and Manchuria to Kyŏngsŏng (today's Seoul) erase the 38th parallel, which momentarily enables audiences to redraw the national borders beyond a divided Korea.

Assassination features a star-studded cast, and the film deftly interlaces diverse traits borrowed from popular genres such as historical drama and heist movie. While the main storyline, inspired by real events, follows the Heroic Corps' plan to assassinate a Japanese military leader and a Korean collaborator together, the subplots enhance psychological familiarity and verisimilitude via characteristics of the heist movie. For instance, we encounter a young female sniper, An Okyun, who was brought up in battlefields and has been fighting with an independence guerrilla group in Manchuria. An Okyun, played by Jeon Jihyun, is drafted for the united mission by the Provisional Government and the Heroic Corps. While inspired by patriotism, An Okyun frankly expresses curiosity about and desire for urban modernity when she finds out that she will be transported to Kyŏngsŏng: "I want to try that drink they call coffee and go on dates". The film's introduction features a female lead who delivers a sense of verisimilitude yet betrays the expected nationalist portrait of a freedom fighter. Similar to the opening's characterisation of the female independence fighter, the film's delineation of armed resistance merges the conventions of historical epic and heist film. With the characters' diversified motivations for participating in a patriotic cause, the director of Assassination, Choi Dong-hoon, who previously directed the caper blockbuster The Thieves (2012), tunes audience attachment to a bunch of not so solemn or heroic freedom fighters, much like the petty conmen in The Thieves. Although the film's treatment of their personal flaws and slapstick gags may seem beneath the sober image of a self-sacrificing patriot, this tactic provides contemporary audiences with a renewed, "authentic" connection to those young activists who had been kept on a pedestal. While these characters are regarded as criminals in the eyes of an exploitative and overpowering system that serves colonial and capitalist interests, contemporary audiences can identify with the film's familiarising characterisation of them as multifaceted, likable modern subjects with flaws and desires. The film's popularity proves that its light-hearted, fast-talking and stylish characters appeal to younger South Korean audiences who yearn for a less conservative social order, especially by representing "a utopian impulse, or at least bohemian one, to form an unconventional collective on the margins of society", which often underlies the generic features of heist movies (Lee 2014: 8). However, the balance between those approachable characters and the factual gravity of historical drama is maintained by the film's deployment of figures such as Kim Gu, leader of the Provisional Government in Shanghai, and Kim Wonbong, a leader of the Heroic Corps. 
In addition, the film creates a pleasing, believable virtual space on which contemporary audiences can project a revised memory of Koreans of the colonial past. The high production values, with detailed attention to costumes and set design, bring to life locations such as Manchuria, Shanghai and Kyŏngsŏng. The film's seamless merger of a meticulously built set and advanced CGI technologies reconstructs the modernity of Korea's capital in the 1930s, which had begun to embrace western culture through gateways like Shanghai and Tokyo. Landmarks like Kyŏngsŏng Station and Mitsukoshi Department Store look sophisticated enough that viewers will want to associate with them, and the images of those historical places show abundant detail to "resuscitate a materialised form of cultural memory" in response to desires for a renewed national identity (Kuhn 2010: 303). Hence, Assassination thematically and aesthetically offers a synthetic memory of the colonial past, which is colourful and exciting for Korean audiences in the mid-2010s. The freedom fighters' fastidiously choreographed actions unfold upon the elaborate backdrop, reviving Kyŏngsŏng's bustling boulevards on the big screen, and transport memory of the era away from what Jinsoo An calls "[a] negative space of austerity ... such as dark passages, back alleys, underground meeting places, and abandoned houses", characteristic of the preceding generation of colonial films (2018: 9).

The Age of Shadows has a palpable film noir style. Whereas Assassination endorses the freedom fighters and their associates, The Age of Shadows blurs the line between patriot and traitor from its beginning. The central plot of espionage follows the wayward path of Yi Chŏngch'ul (played by Song Gang-ho), an exresistance fighter who now works as a police captain with the Japanese government. Because of Yi's background in the independence movement, a senior officer orders him to infiltrate the Heroic Corps, placing him under enormous pressure. Yi finds himself torn between his obligations as a spy and his developing friendship with Heroic Corps fighter Kim Ujin (played by Gong Yu), who is in fact already aware of Yi's identity and mission. In order to underscore Yi's opposing identities, the film deploys ambient metallic blue hues, accented with an occasional orange shimmer that quickly turns into a fading brown and draws heavy shadows on the face of this double agent caught between opposing desires and two nations. Lowkey light, multiply framed and segmented shot composition, distorting camera angles, and expressionistic use of mise-en-scène, all borrowed from film noir, foreground the dilemma confronted by Koreans under Japanese rule.

Wheeler Winston Dixon's Film Noir and the Cinema of Paranoia hyperbolically argues that film noir used to be an expressionist cinematic mode to capture the underlying psychological insecurity of the 1930s and 1940s, yet now offers contemporary filmmakers a stylistic template for a vision of contemporary conditions:

This is the age of film noir. Though the genre dates from the late 1930s and early 1940s, its concerns of hopelessness, failure, deceit and betrayal are in many ways more prescient in the 21 st century than they were at their inception. 
In a similar vein, The Age of Shadows utilises film noir as an aesthetic tool to construct not only visual but also thematic bridges between the two eras for contemporary South Korean audiences' prosthetic memory of the colonial past. Just as film noir recurs in the twenty-first century, the problematics of modernity, in Saunders' terms, as a phenomenon transcending spatial-temporal containment, are recast in the filmic representation of the colonial past. In this sense, generic markers of film noir in The Age of Shadows draw audiences' attention to a similar amalgam of hope for a better future, growing national pride, underlying uncertainty and frustration over the socioeconomic, political, cultural and psychological situations of both the colonial period and the mid-2010s. The Age of Shadows' orientation towards film noir can thus be read as evoking a link between the two periods.

While Assassination's adoption of the features of a heist film reflects a positive reading of Korea as a modern state, the conventions of film noir in The Age of Shadows imply that colonial Korea and South Korea in the mid-2010s are experiencing similar symptoms of "hopelessness, failure, deceit and betrayal". Seen through this pessimistic generic lens, contemporary South Korea mirrors its colonial despair in repeating the tangled political conflicts between Korea and Japan, an uncertain future overshadowed by inequality and injustice, and sociopolitical conservatism that recalls an authoritarian past. The self-mocking expression "Hell Chosŏn", a neologism combining "hell" and "Chosŏn" (Korea's last monarchy with rigid class hierarchy), has become widely used in the 2010s and reflects the reality of contemporary Korea, where people from unprivileged backgrounds cannot escape exploitation, just like those who struggled under the Joseon's feudal class system. In its thematic and contextual alignment with film noir and contemporary mood, even the final moments of The Age of Shadows refrain from celebrating the end of Japan's occupation and end in a jail, where Kim Ujin is locked up after the failure of the Heroic Corps' mission. The last image of Kim, tortured and lost in thought, is cut to a scene where a young freedom fighter takes the bombs to the Government-General Building to complete the failed mission, although the film leaves it unclear whether this is Kim's reverie or real in the film's narrative. This open ending may reasonably stir thoughts for the audience about such gestures of resistance as a means to overcome depressive social conditions, equally symptomatic of contemporary times.

While the two films similarly utilise familiar generic codes as a means to connect the colonial past and contemporary viewers, Assassination and The Age of Shadows differ markedly in their characterisation of pro-Japanese collaborators. In Assassination, freedom fighter operations involve killing a traitor, Kang In'guk, who remains faithful to the colonial power, even ordering his wife killed when she tries to help a resistance fighter escape the Japanese police. Later Kang attempts to murder his long-lost daughter An Okyun, now a formidable sniper with the Heroic Corps commissioned to assassinate him, unaware of their relationship. Another major character, Yŏm Sŏkchin, is depicted as a collaborator who ruins the assassination plans from within. A member of the Provisional 
Government and an experienced freedom fighter, Yŏm sells the information about the mission to the Japanese police and is rewarded by promotion to police chief. Both pro-Japanese collaborators dress in black fur or leather, which symbolises their predatory dispositions. Their treachery and collaboration is confirmed from early scenes and, hence, their roles in the film's narrative as villains.

Nonetheless, the film thematises the "blood" ties between patriots and traitors, which paradoxically renders the young freedom fighters and their archenemies inseparably bound despite motivations and choices that divide the traitorous villains, seeking advancement under colonial authority, from the freedom fighters, working for the forsaken motherland. Moral and emotional dilemmas, as well as tantalising delays in plot, recur due to Kang's status as biological father to An Okyun and Yŏm's lasting influence over the junior resistance fighters of the Provisional Government. In order to add complexity to the dilemma of the innate bond between traitor and patriot, the film presents the back story of a hitman nicknamed Hawaiian Pistol, who recounts his murder of his father, who, in the son's view, had opened the gates of the nation to the enemy. Hawaiian Pistol has thus already experienced trauma in severing familial bonds and killing his father, who collaborated with, supported or merely accepted the colonial invasion. Therefore, the film's climatic moments arrive when the freedom fighters help one another break free from these dilemmas and take down the two traitors: Hawaiian Pistol assists An Okyun in her mission to assassinate her collaborator father and An Okyun assists a freedom fighter whose mission is to kill the fatherly Yŏm after Liberation.

In contrast to Assassination's black-and-white portrayal of collaborators, The Age of Shadows delves into the psychological ambivalence and dilemmas of Yi Chŏngch'ul, who straddles the border between patriot and traitor. The film dwells on, instead of resolving, the impossibility of determining the true intentions and identity of the central character, who resembles film noir heroes of questionable moral standing. Yi, a captain in the Japanese police, finds a young, ambitious and ruthless version of himself in Hashimoto, an ethnic Korean policeman single-mindedly obeying the order to arrest independence fighters. Hashimoto offers Yi and the audience a sinister image of loyalty towards the Japanese Empire for individualistic desires to win a better seat in the modernised Korea. In this sense, Hashimoto's death by Yi's hand on a train from Shanghai to Kyŏngsŏng foreshadows the decision that Yi will make to end the internal conflict and that the film seems to endorse. Yi sees another image of himself in Kim Ujin, who wilfully treads the uncertain path towards Korea's emancipation. Yi walks a tightrope between these opposites while carrying out a covert operation to arrest the leader of the Heroic Corps and its members. Ultimately, he draws blood from both parties: Yi shoots Hashimoto and his men on the train in order to help Kim Ujin, yet he is forced to torture Kim's female colleague, who is arrested on the Heroic Corps' arrival at Kyŏngsong. After the failure of the police operation as well as the resistance group's bombing plan, Yi Chŏngch'ul is put on trial in the colonial court. His teary testimony that he was merely doing his job as a Japanese police officer convinces neither the judges nor the film's 
audience. Our interpretation about his support of the Heroic Corps is suspended because it is left ambiguous whether Yi denied his ties to the independence fighters as a survival tactic in court or he was truly torn between two identities. In this manner, The Age of Shadows offers psychological verisimilitude for audiences living through a confusing contemporary era characterised by political division between conservatives and progressives, economic recession and social polarisation. The film's unorthodox protagonist, Yi Chŏngch'ul, a freedom fighter turned collaborator, thus allows audience members to imagine their own potential choices on the twisted path of modern Korean history. Moreover, the demand for making a choice persists, just as in the case of $\mathrm{Yi}$, who repeatedly crosses the line between traitor and patriot and takes on multiple identities in accordance with his choices.

Ultimately, how should we interpret the shifts in Korean cinema's remembering of the colonial past in light of the still troubled relationship between Korea and Japan? If nothing else, the films under discussion accentuate the Korean public's search for a new position in collective memory of the past and offer grounds for embracing awareness that their forebears had as much agency in their choices, whether fighting for Korea's independence or siding with Imperial rule, as viewers of today. Indeed, the films appear to recall that agency was exercised by both those who broke free from personal wishes for the sake of their lost nation and those who turned their backs to their troubled country to collaborate with Japan and rode the currents of history towards modernity. In this sense, the films imply that both choices entail a load of responsibilities and price, some of which were paid dearly and others are yet to be paid. Assassination and The Age of Shadows also highlight the fluidity of ethnic, national and cultural identities among self-sacrificing patriot, average colonial subject and pro-Japanese rat. The characters in both films experience their subjectivity in transition from the traditional Confucian values to an expanding, dynamic modern world governed by diverse personal, capitalistic desires. Likewise, contemporary imaginations of those Koreans who lived on the threshold to a new era will remain in motion as long as their portrait of Korea is placed closer to the nation's present than its past.

\section{References}

An, Jinsoo. 2018. Parameters of Disavowal: Colonial representation in South Korean film. Oakland, CA: University of California Press.

Bronfen, Elisabeth. 2006. "Reality Check: Image Affects and Cultural Memory". differences, 17 (1): 20-46.

Chua, Beung Huat. 2017. "State Violence, Social Memory, and the Ethics of Remembrance and Forgiveness in East Asia". Situations, 10 (1): 1-22.

Dixon, Wheeler Winston. 2009. Film Noir and the Cinema of Paranoia. Edinburgh: Edinburgh University Press.

Gateward, Frances. 2007. "Waiting to Exhale: The colonial experience and the trouble with my own breathing”, in Seoul Searching: Culture and identity in contemporary Korean cinema, edited by Frances Gateward. New York: SUNY Press: 191-218. 
Kang, Kyoung-lae. 2015. "Kyung-Sung: Cinematic memories of the colonial past in contemporary Korea". Camera Obscura, 30 (3): 27-59.

Kang, Kyoung-lae. 2016. "Embracing Postcolonial Potentiality: New faces of proJapanese collaborators in contemporary Korea", in Spaces of Possibility: In, between, and beyond Korea and Japan, edited by Clark W. Sorensen and Andrea Arai. Seattle and London: University of Washington Press: 224-252.

Korean Film Council website: www.kobis.or.kr/kobis/business/stat/offc/findYearly BoxOfficeList.do?loadEnd $=0 \&$ searchType $=$ search\&sSearchYearFrom $=2018 \&$ sMulti MovieYn=\&sRepNationCd $=$.

Kuhn, Annette. 2010. "Memory Texts and Memory Work: Performances of memory in and with visual media". Memory Studies, 3 (4): 298-313.

Lacan, Jacques. 2006 [1949]. "The Mirror Stage as Formative of the $I$ Function as Revealed in Psychoanalytic Experience", in Écrits. Trans. Bruce Fink. New York and London: W. W. Norton \& Company: 75-81.

Lee, Daryl. 2014. The Heist Film: Stealing with style. London and New York: Wallflower.

Saunders, Rebecca. 2007. Lamentation and Modernity in Literature, Philosophy, and Culture. New York: Palgrave Macmillan.

Silverman, Kaja. 1996. The Threshold of the Visible World. New York and London: Routledge.

Strupples, Peter. 2003. "Visual Culture, Synthetic Memory and the Construction of National Identity". Third Text, 17 (2): 127-139.

Taylor-Jones, Kate. 2017. Divine Work, Japanese Colonial Cinema and Its Legacy. London: Bloomsbury Academic \& Professional.

White, Hayden. 1996. "The Modernist Event", in The Persistence of History: Cinema, television and the modern event, edited by Vivian Sobchack. London and New York: Routledge: $17-38$.

\section{Filmography}

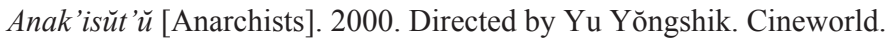

2009: Rosŭt'ǔ Memori [2009: Lost Memories]. 2002. Directed by Yi Simyŏng. Indicom. YMCA Yagudan [YMCA Baseball Team]. 2002. Directed by Kim Hyŏnsŏk. Myung Film. Ch'óngyŏn [Blue Swallow]. 2005. Directed by Yun Chongch'an. Korea Pictures.

Kidam [Epitaph]. 2007. Directed by Chŏng Shik and Chŏng Pŏmshik. Film Dorothy.

Modŏn Poi [Modern Boy]. 2008. Directed by Chŏng Chiu. KnJ Entertainment.

Radio Teijŭ [Radio Dayz]. 2008. Directed by Ha Kiho. Sidus Pictures.

Myŏngryang [The Admiral: Roaring Currents]. 2014. Directed by Kim Hanmin. Big Stone Pictures.

Amsal [Assassination]. 2015. Directed by Ch'oe Tonghun. Caper Film.

Kyŏngsŏng Hakkyo: Sarajin Sonyŏdŭl [The Silenced]. 2015. Directed by Yi Haeyŏng. Generation Blue Films.

Taeho [The Tiger: An Old Hunter's Tale]. 2015. Directed by Pak Hunjŏng. Sanai Pictures.

Agassi [The Handmaiden]. 2016. Directed by Park Chan-wook [Pak Ch'anuk]. Moho Film and Yong Film.

Haeworhwa [Love, Lies]. 2016. Directed by Pak Hŭngshik. The Lamp.

Kwihyang [Homecoming]. 2016. Directed by Cho Chŏngnae. JO Entertainment. 
Miljŏng [The Age of Shadows]. 2016. Directed by Kim Chiun. Warner Brothers Korea. Tongju [Dongju: The Portrait of a Poet]. 2016, Directed by Yi Junik. Lyz Y Sonidos. Tŏk'ye Ongju [The Last Princess]. 2016, Directed by Hŏ Chinho. Ho Film.

Pak Yŏl [Anarchist from Colony]. 2017. Directed by Yi Junik. Park-yeol Culture Industry Co., Ltd.

Kunhamdo [The Battleship Island]. 2017. Directed by Ryu Sŭngwan. Film maker R\&K. 


\title{
5 Korean kamikaze pilots in Japanese films
}

\author{
Rumi Sakamoto
}

Kamikaze, commonly known as tokkōtai (special attack corps) in Japan, have held iconic status in the post-war Japanese imagination. Only recently, however, has the existence of Korean kamikaze pilots entered public consciousness. This chapter examines the representation of Korean kamikaze in two early twentyfirst-century films: Hotaru (Firefly, dir. Furuhata Yasuo, 2001) and Ore wa kimi no tame ni koso shini ni iku (I Will Go and Die for You, dir. Shinjo Taku, 2007, hereafter I Will Go). It explores how each, to very different effect, foregrounded stories usually excluded from Japan's kamikaze narrative. Korean kamikaze, as colonised subjects dying (and killing) for an empire that subjected their homeland to harsh rule, can challenge images of kamikaze as tragic national heroes; their presence complicates, if not reshapes, Japanese memory of the Asia-Pacific War, often construed as a war against America, thus disassociating Japan from its imperial past.

At least 17 Korean kamikaze pilots died in Japan's war (Yoshida et al. 2014: 115), perhaps more; exact determination is difficult because they were recorded under their Japanese names. Research on Korean kamikaze remains limited in Japan as well as Korea, where they are stigmatised as traitors (Kwon 2017: 251). ${ }^{1}$ Nevertheless, their existence highlights the entangled nature of colonial violence and, as Yoshida (2008: 17) points out, challenges the dominant kamikaze narrative as a uniquely Japanese story of dying for one's country that legitimises nationalist agendas. Taking a cue from Yoshida, then, I ask to what extent insertion of Korean kamikaze into Firefly and I Will Go interrupts these hegemonic representations, and how each film engages with war memory and positions itself with respect to envisioning future Japan-Korea relations.

This focus on representation of Korean kamikaze draws attention to the complexities of war memories between Japan and Korea, whose competing exclusionary desires to nationalise war memories have harmed relations between them; only multiple rememberings that go beyond "our" and "their" memory do justice to messy historical reality, where victims and victimisers are not always neatly demarcated. Intersecting and overlapping war memories of citizens, military officers, women, foot soldiers, "collaborators" and others make a unitary national memory even more problematic. In this context, inserting Korean kamikaze into what has been constructed as a Japanese story of heroism and tragedy 
offers opportunities to think about war memory and future relations outside hegemonic national frameworks. To what extent is such potential realised in each film?

In the following, I discuss post-war tropes of kamikaze pilots as Japan's tragic heroes, then analyse Korean kamikaze in Firefly and I Will Go to examine how each engages with this dominant image. I argue that while I Will Go depends on and reproduces the "national" framework, subsuming its Korean character into hegemonic images of kamikaze, Firefly acknowledges the ambivalent subjectivity of a Korean kamikaze and explores reconciliation outside such dominant national frameworks.

\section{Kamikaze in post-war Japanese media}

During the last stage of the Asia-Pacific War, almost 3,900 young men died in desperate kamikaze suicide attacks against an enemy with far superior power. The image of kamikaze pilots tasked with crashing their bomb-laden planes into US ships has been often reproduced in Japanese media, though its meaning has shifted over time. While revered as living gods (gunshin, literally "military god") in wartime representations, defeat and bitter reflections over militarist ultranationalism transfigured images of kamikaze into deranged fanatics and/or ignorant victims of militarism. After the US Occupation and the lifting of censorship, more positive depictions appeared; a 1960s kamikaze film boom saw the pilots wrapped in sentimentalism, pathos and beauty (Sato 1974: 84). Then came a blank period: between 1974 and 1990, amidst Japan's maturation into an affluent society with an advanced consumption culture, which relegated the war and its after-effects increasingly to the past, not a single kamikaze film was made (Nakamura 2017: 229). This period also saw changing perceptions about the war, with growing acknowledgement of Japanese aggression - a result of numerous publications on war atrocities and colonialism, as well as a surge of citizen activism that addressed war guilt and responsibility (Yoshida 2014). Kamikaze, often seen as a symbol of militarism, understandably lost favour as a theme in popular culture.

Kamikaze reappeared in 1990s entertainment and consumption culture as the country fell into recession, against the backdrop of intensifying historical debate between Japan and Korea/China around issues such as "comfort women" and the Nanjing Massacre, which provoked a revisionist backlash. In 1995, two films on kamikaze (Fly Boys, Fly; The Winds of God) commemorated the fiftieth anniversary of the war's end. By the twenty-first century, various media including film, manga, pop literature, theatre, museums and battlefield tourism had interacted to establish kamikaze as national icons and prevalent symbols of Japan's war (Fukuma and Yamaguchi 2015; Sakamoto 2015; Inuzuka 2016; Nakamura 2017; Seaton 2018). Unlike the earlier period when associations with militarism made kamikaze taboo, aestheticised kamikaze images now abound in popular media.

While meanings produced around kamikaze have not been monolithic, twenty-first-century depictions have generally centred upon the theme of young 
pilots, who accepted self-sacrifice for something beyond themselves - family and loved ones, or hometown and the nation, but rarely the emperor or the Japanese empire. Sentimentalism and aestheticisation dominate. The pilots' inevitable death, no matter how cruel and unreasonable, highlights and intensifies their struggles, integrity, self-control and passion. No matter whether emphasis falls on heroism or victimhood, affect-drenched narratives promote empathy and admiration of their courageous, dignified acceptance of fate. Such representations are often made relevant to contemporary audiences via the ideas that kamikaze paid the ultimate price in order to build a foundation of peace, and that their stories may teach lessons and provide inspiration.

These kamikaze narratives are usually told from a Japanese perspective, contributing to memory of the Asia-Pacific War as Japan's tragedy. The crystallisation of kamikaze into icons of courage, purity and sorrow meant foregoing attention to the victims of their attacks or Japan's war in Asia. Twenty-firstcentury kamikaze representations thus fit well with the agenda of Japanese conservatives and nationalists, who have strived to produce new collective memories of the war and structures of feeling surrounding it to promote national pride. Liberal critics have warned that such aestheticisation of self-sacrifice promotes dangerous loyalties to the country and future patriotism. Prime Minister Abe's push for the revision of Article 9 makes it plausible that heroic kamikaze stories are propagated in part to inspire willingness in new generations to die for Japan. At a minimum, these images contribute to perceptions of kamikaze not as fanatics or aggressors but as self-sacrificing tragic heroes. Certainly, both promoters and critics now regard the equation between kamikaze and the Japanese war as self-evident.

Within this trend, Firefly and I Will Go stand out for their use of Korean kamikaze. On one level, filmic inclusion of Korean pilots reflects heightened awareness of unresolved issues in Japan's colonial and wartime past. From the 1990s, a newly confident South Korea challenged Japanese views of history and its colonial and war responsibilities, especially over the "comfort women". Meanwhile, Showa Emperor's death in 1989 lifted domestic taboos on talking about his (and Japan's) war responsibility, and the end of LDP dominance in 1993 further loosened public discourse on Japan's imperialism. Prime Minister Murayama's apology for Japan's colonial rule and aggression on the fiftieth anniversary of the war's end, while hailed as a historic step towards ameliorating relations with Japan's neighbours, caused deep resentment among Japanese conservatives. The struggle over collective memory between those who glorified the war as a struggle for Asia's liberation and those who challenged such views intensified.

By the end of the twentieth century, public discourse was divided. The liberal left aligned themselves with Asian victims, while the conservative right denied Japan's war responsibility. Governments came and went, apologies were issued and challenged, and "comfort women" appeared and disappeared from school textbooks. As these events made regular headlines, Japanese people were forced to face the unresolved business of Japan's war and atrocities in Asia. Views of 
Japan as victimiser, and not merely victims of atom bombing, could not be ignored, although no consensus emerged on how the national community should remember the war and its violence. This period also witnessed growing voices from outside official state memories, and non-Japanese victims of atomic bombs and Okinawans victimised by the Japanese military increasingly sought recognition. The references to a Korean kamikaze in Firefly and I Will Go exemplify attempts to intervene in memory politics by reimagining Japan-Korea relations via a cultural icon.

Both films draw loosely on stories of kamikaze at Chiran Air Base, as later told by Torihama Tome, the "mother of kamikaze", who ran a restaurant where pilots spent their final days. One of them, Tak Kyung-hyun (Lieutenant Mitsuyama), who is known to have sung the quintessential Korean folk song "Arirang" the night before his suicide mission, served as inspiration for the Korean pilot in both films. Each film self-consciously markets itself as a "true story". Images from news reports, documentaries and snapshots of the pilots' final toast, a plummeting fighter plane, etc. imply a link with history in both. Visual and narrative references to real events attempt to enhance a sense of authentic recreation. Yet, as I argue below, the films' engagements with memory politics through their representation of a Korean kamikaze pilot differ markedly.

\section{Firefly and repressed trauma}

Made in 2001, Firefly was conceived, screened and consumed at a time of growing contestation over Japan's war memory. In that year Prime Minister Koizumi started his provocative annual Yasukuni visits, marking a transition into an unsettled decade during which Japanese nationalists and revisionists extended their influence. Inspiration for Firefly apparently came when lead actor, legendary Takakura Ken, learned of Torihama Tome and felt compelled to transmit the "true story" of kamikaze in film, a medium he believed had unique abilities to preserve what would otherwise be forgotten (Kanazawa 2001: 82). Takakura's desire to pass on kamikaze stories to the next generation of Japanese was shared by both the director and the head of the film studio and eventually resulted in an exclusive screening for high school students, followed by a discussion event between Takakura and the young audience.

The use of a Korean pilot in attempting to transmit "true history" makes Firefly unique among kamikaze films. Its thematisation of Japan-Korea relations attracted the attention of critics, who saw within it an approach ranging from "a firm engagement with the aspect of Japan as victimiser" (Yamada 2007: 83) to an "antiJapanese message" (Yagi 2001: 162), largely reflecting their own ideological inclinations. As I will show, Firefly is complex enough to allow this range of readings, but this striking use of a Korean certainly made a strong impression among the viewers. $^{2}$ The film achieved ninth position at the box office in 2001 and received nominations in all 13 categories at the Japanese Academy Awards.

Set in the year of the Showa Emperor's death, more than 40 years after war's end, Firefly focuses on Yamaoka, a former kamikaze who survived a failed 


\section{Rumi Sakamoto}

attack. His wife Tomoko had once been engaged to Lieutenant Kanayama, ${ }^{3}$ a Korean pilot and Yamaoka's senior officer, who died in a suicide mission. The film, interspersed with wartime flashbacks, depicts Yamaoka's life with Tomoko, the post-war suicide of fellow surviving kamikaze Fujieda, and Yamaoka's dealings with others, including the restaurant owner and "mother of kamikaze" Tomiko and Fujieda's granddaughter. The film ends with a long scene in which Yamaoka and Tomoko visit Korea to deliver Kanayama's final words and a keepsake to his relatives, making Firefly Japan's first post-war feature partially shot in Korea (Noji 2014). ${ }^{4}$

Repressed trauma lies at the heart of Firefly. The protagonists say little about their wartime experiences, though clearly marked by the past. Whenever the war is broached, Yamaoka bluntly pushes it away: "There's nothing to say". ${ }^{5}$ Fujieda, too, is reticent about his kamikaze past, yet the film's visual register indicates that it haunts him: a close-up captures his pained expression as he visits the Chiran Kamikaze Museum and stares at portraits of deceased pilots and documentary footage of attacks. The characters frequently look pensively out to sea, or out of the window in silence, making the presence of unexpressed trauma palpable.

Memories of Lieutenant Kanayama function as a catalyst for breaking the silence and moving the narrative forward: all the main characters have clearly lived the post-war years with Kanayama in mind. Kanayama was the love of Tomoko's life, cruelly sent to die. Yamaoka plays a tune liked by Kanayama on

his harmonica when alone. Fujieda's suicide note reveals his last thoughts are of Kanayama. Tomiko, the restaurant owner, keeps a small Korean mask that Kanayama entrusted to her before his death, hoping someday to return it to his family. Yamaoka, pushed by his wife's terminal illness, Fujieda's death, and a plea by ageing Tomiko, decides to travel to Korea with his wife, return the mask and relate Kanayama's last words, which he has kept to himself for over four decades. This climactic visit symbolises a shift from silence and repressed trauma to a commitment to confront the past and pass on memories to future generations.

Throughout the film, Kanayama only appears in others' memories, in black and white flashbacks. The visual demarcation indicates a separate timeline and repressed memories that break into the present. Dreamlike sequences reveal Kanayama's Korean origins, his relationship with Tomoko and his last day before his suicide mission. In one scene he tells Yamaoka and Fujieda that his real name is Kim Songje and speaks nostalgically of his homeland; in another, Tomoko chases Kanayama's fighter plane as it is about to take off, tearfully begging to be taken along. Importantly, the film repeats Kanayama's last day, when he dictates his farewell to Yamaoka and Fujieda, with minor variation three times, twice in incomplete form. The day as a whole is only witnessed at film's end in its third enactment, when Yamaoka relays Kanayama's words to his relatives in Korea. The repetition hints at the recurring nature of traumatic memory and unresolved issues in need of addressing.

The repressed trauma of Firefly invokes Kanayama's death and how others cling to this loss after the war, but it can also be read as a substitute for 
memories of a dark Japanese colonial history that dragged Korean subjects into an imperial war, recurrent memories that resist articulation and thwart a sense of closure. In such a reading, the Korean relatives' eventual acceptance of Yamaoka as a legitimate messenger of Kanayama after initial rejection becomes a moment of healing. Historian Igarashi Yoshikuni (2007) criticises this scene as an "easy way out" of the Japan-Korea conflict over history. Reading Firefly's ending as a fictive reconciliation, designed to avoid questions of responsibility and Japan's role as perpetrator, he argues that the scene signifies "post-war Japan's desire ... to foreclose its war story once and for all" (110). Such assessment is generally shared by others (Morris-Suzuki 2013; Dew 2016; Taylor-Jones 2017), though Igarashi offers the earliest and most detailed analysis.

Below, however, I offer a more sympathetic interpretation that emphasises the film's ambiguity and fluidity. Firefly is a complex text whose meaning spills beyond simple desires for closure and forgetting, into an alternative act of remembering traumatic war experience. I do not deny that Firefly offers fictional reconciliation but note how its culturally imagined reconciliation in fact engages with, rather than ignores, war trauma and colonisation, even if subtly.

Significantly, Igarashi does not address the larger discursive field in which Firefly is embedded. As cultural studies have long acknowledged, however, the meanings of media text representations are over-determined by social and historical context. The interpretation of Firefly relies on public understanding of Japan's colonial past; without such knowledge, the Korean relatives' initial anger, for example, makes no sense. While Firefly does not detail Korean suffering under Japanese occupation, the absence of explicit reference hardly signifies desire to forget the past, because, in 2001, this legacy was shared and inescapable public knowledge. Indeed, Firefly opened five months after a high-profile women's international tribunal on Japan's military sexual slavery held in Tokyo, and just one month after the government approved a new textbook written by a revisionist group, which sparked the so-called history textbook crisis. As such "history problems" divided Japanese society, Firefly engaged with a public discourse increasingly marked with binary oppositions of Japan and Korea as victim and victimisers, by highlighting a Korean kamikaze - an ambivalent, rarely spoken of colonial subject that straddles two contradictory national positions.

\section{Resisting national narratives}

Firefly challenges the portrayals of kamikaze as national icons and imagines reconciliation outside the dominant framework of competing nationalisms. Typically, reconciliation over historical wrongs is conceived of as an act between victim and victimiser that entails apology, acceptance of responsibility and compensation. Firefly complicates this premise in several ways.

On one hand, Firefly establishes the strength of Kanayama's Korean identity, as seen in his revelation of his Korean name, his yearning for his hometown, and above all, his message of farewell, entrusted to Yamaoka and Fujieda before his final flight: "I will surely sink the enemy ship. But I'm not dying for Japanese 


\section{Rumi Sakamoto}

empire! ... I will go as a proud Korean, for my family in Korea and for Tomosan. Korean people, banzai. Tomo-san, banzai”. Kanayama's words, presented to the audience as his "true feelings", challenge hegemonic images of kamikaze as tragic national heroes and draw audience attention to a colonial relationship. While the film does not illuminate what it means to die in a kamikaze attack as a "proud Korean", or how the suicide mission could benefit a Korean family, Kanayama's Otherness is clear.

On the other hand, Kanayama is not represented as a pure Korean patriot. Such a representation would overlook his complexity as a dislocated colonial subject, trapped in intertwined national histories. Unlike stereotypical Korean images of colonial-era patriots, of course, his Koreanness is not inscribed with heroic anti-Japanese resistance. He dies in Japanese military uniform, determined to sink an "enemy" ship, that is, enemy of the Japanese empire that colonised his homeland. His recognition of America as enemy suggests partial alignment of his subjectivity with Japan, and his romantic relationship with Tomoko and fluent Japanese further mar his "pure" Korean identity. ${ }^{6}$

While such details may point to the figure of a collaborator, object of hatred in nationalistic Korean post-war agenda, Firefly questions a Korean nationalism that divides its people into patriots and traitors. Tomiko's daughter informs Yamaoka that Korea has refused the return of the bones of Korean kamikaze and that more than 1000 Korean soldiers' remains are kept in a temple in Tokyo. The implication is that many, like Kanayama, occupied an in-between position that bars them from returning home, even in death. Yamaoka's personal delivery of a keepsake of Kanayama's to Korea is proposed as a way of eluding this impasse born out of nationalist paradigms.

By depicting Kanayama with an unwavering Korean self-identity that leads him to declare unequivocally that he is not dying for Japan, yet as so deeply Japanised that he sings the second verse of Arirang in Japanese, Firefly brings the contradictions of colonial subjectivities into focus. Although in post-war Korea, Korean kamikaze are despised as collaborators, colonial domination means that many Koreans would have cooperated (or been forced to cooperate) with Japan to varying degrees. Considering how the Japanese state mobilised Koreans into war by making them "more Japanese than Japanese" (Bae and Nogi 2008: 24), to condemn "collaboration" as treason risks turning a blind eye to any continuum between pure victim and evil victimiser.

While Kanayama's ambivalent positioning challenges nation-centric discourses and a Japan-Korea dichotomy, the usual first issues to be tackled in moving towards reconciliation, Yamaoka's visit to Kanayama's hometown initially evokes just such a Japan-Korea opposition. The refusal of Kanayama's relatives to forgive Japan after so many years is palpable in their anger and, their unwillingness to accept Kanayama's death as a kamikaze and questioning why he had to die, while Yamaoka, a Japanese, survived. Shot in the well-known traditional village of Hahoe, using local actors and preceded by images of masked dancers in a folk festival, the segment produces an effect of cognitive estrangement and enhances Otherness. 
At the same time, however, the scene stimulates empathetic orientation towards the Other. Conversation throughout the 18-minute segment relies on an interpreter and eschews subtitles, exposing the audience to lengthy speech in Korean. The Korean actors' harsh expressions and tone of voice viscerally convey their emotions, while meanings of their utterances are suspended. As Sobchack (2004) has argued, film's moving images produce experience and meaning for the audience not only via intellectual means but through bodily engagement, by “touching" us with pre-discursive affect. Firefly's postponement of translation forces monolingual Japanese audience members to first register the family's intense emotion as embodied experience and draws them in as fellow participants. Close-ups of the Korean relatives' faces also encourage sympathy towards their perspective. The scene thus shifts from distancing the Korean Other to prevent viewers' easy identification towards promoting sympathy through a sense of immersion.

The initial confrontation that gives way to symbolic reconciliation here diverges from the standard model of apology and forgiveness between perpetrator and victim. Although this scene has been interpreted as "Japanese atonement" (Taylor-Jones 2017: 176) and "desire for forgiveness" (Morris-Suzuki 2013: 168), it is important to note that here Yamaoka is not driven by remorse over Japan's colonisation of Korea but rather personal memory of his senior officer and survivor's guilt. He is not there to apologise, nor do the Korean relatives offer forgiveness. They simply accept Yamaoka as Kanayama's messenger. Both parties share recognition of harm done and honour Kanayama's memory together.

One might argue that "reconciliation" without acceptance of responsibility, apology and forgiveness is meaningless; such viewpoints seem inherent, for instance, in the struggle over the comfort women issue. However, while the language of culpability, apology and compensation is important for legal, political and institutional reconciliation, cultural productions can engage historical memory differently. Using affective, not necessarily cognitive, language, such texts can capture nuance and ambiguities. Firefly, with its refusal to tell a "Japanese" story and its lopsided "reconciliation" between a Japanese former kamikaze and the relatives of a dead Korean kamikaze, addresses the entanglements of suffering, victimisation and responsibility in war and creates space for articulating a vision of reconciliation outside the dichotomies of competing national narratives. Yamaoka breaks his silence to convey not his own kamikaze experience but Kanayama's words from over 40 years ago. In stating "if we said nothing, it' $d$ be as if Lieutenant Kanayama never existed ... as if his words and emotions never existed", he bears witness to the memory of Kanayama, an Other in the Japanese Empire. What occurs thus differs from the story of apology, forgiveness, closure, redemption of forgetting.

Trauma theory holds that for healing to occur, a sufferer must acquire narrative control over what happened; one must understand, retell and master painful experience by working through it and giving it meaning (LaCapra 2001; Herman 2015). Kamikaze narratives in post-war Japan can be seen as part of 
such attempts to make sense of the war and its trauma via cultural remembrance. But neither Yamaoka nor the filmic text as a whole works through, understands or integrates his or Japan's trauma. Rather than narrate a national story to heal collective trauma, Firefly's key scene has Yamaoka simply relay Kanayama's words that he died not for the Japanese empire but as a "proud Korean". The voices of Kanayama and Yamaoka merge, and "Arirang", started by Kanayama in the flashback to his final night, is finished by Yamaoka in front of Kanayama's relatives. An old woman in a wheelchair moves forward to receive Kanayama's mask from Yamaoka, as the film pushes the audience to feel that Lieutenant Kanayama has returned home at last and reassumed the identity of Kim Songje.

In discussing trauma literature, Caruth points out that intertwining one's own trauma with the Other's may lead to the "encounter with another, through the possibility ... of listening to another's wound" (1996: 8). Importantly, "listening" does not necessarily mean understanding, but rather apprehending "a voice that it cannot fully know but to which it nonetheless bears witness" (9). Kanayama's words, I suggest, become just such a "voice of the Other", to which Yamaoka - a Japanese kamikaze survivor with his own trauma - bears witness though he cannot "fully know" it. As Kanayama's words reverberate across time and space via Yamaoka, the audience also receives a belated opportunity for what Caruth calls "listening to the address of another, an address that remains enigmatic yet demands a listening and a response" (9). As noted, Kanayama's enigmatic, contradictory final words reflect the complex subjectivities of colonial power relations. By avoiding interpretation of his statement, the film leaves viewers to encounter wounds of the Other that are communicated with emotionality rather than symbolically articulated. By making the audience into witness to violence that is neither fully named nor understood, Firefly subtly inserts the Other's trauma into the next generation's war memory.

The film's lengthy final scene reminds viewers that reconciliation rests with those alive now, who can act. The dream-like flashbacks accentuate this contemporary focus, by distancing the past from reality and hindering easy identification with its events. As director Furuhata states, Firefly is "less concerned with the meaning of the past than with what one can do in the present".

[He] made the film as a story of the present ("ima no monogatari") so we can see everything from the perspective of how people alive today think about and act around the war, as well as how we should act in front of others alive today.

(Furuhata 2001: 43)

This sentiment is captured in Yamaoka's statement, "those who died and those who live ... we are all just looking ahead and moving forward as best we can". Looking ahead and moving forward for Yamaoka entails transmitting Kanayama's words and feelings while keeping silent about his own trauma as a kamikaze. Japanese viewers, who encounter Kanayama's words and emotion via the film, must each decide how to engage and respond to the Other's trauma. Firefly 
thus treats the present (and future) as a place of possibility, privileging it and the living over the past and the dead. Ultimately, the film suggests that it may be best to conceive of Japan-Korea reconciliation as "moving forward as best we can", rather than insisting on full resolution and redemption.

Such a reading obviously has a Japanese audience in mind. Furthermore, even if the text encourages such possible reading, actual interpretation lies with the readers. In fact, Firefly was a commercial failure in Korea, and its screening was cut short. Kwon suggests that Korean audiences were not ready to accept the existence of Korean kamikaze (2017: 75). Though some bereaved families of Korean pilots appreciated Firefly (Yamaguchi 2010: 51), Korean audiences were generally critical because of the film's avoidance of depicting colonial rule and racial discrimination (Kwon 2017: 75-76).

Still, I hope to have shown that Firefly does not merely whitewash Japan's role as coloniser. Rather than simply offering fictional forgiveness and catharsis that promote closure and forgetting, it encouraged post-war Japanese audiences amidst intensifying Japan-Korea conflict to imagine and desire future reconciliation, and promoted an alternative, empathic structure of feeling congruent with reconciliation. By incorporating the enigmatic voice of a Korean kamikaze without labelling him hero, traitor or victim, it highlights ambivalence and contradiction in colonised subjects, refusing to reproduce the context of competing nationalisms.

\section{Will Go and Die for You}

Produced six years after Firefly, I Will Go depicts the final days of young kamikaze pilots around the Tomiya restaurant and Chiran Air Base. Given that the author of the screenplay and executive producer is former Tokyo nationalist governor, Ishihara Shintaro, it is perhaps surprising that a Korean kamikaze features in this film at all. Yet, one protagonist, Lieutenant Kanayama, is modelled on Tak Kyung-hyun, as in Firefly. Despite its similar premise, however, I Will Go produces a very different kamikaze memory.

The film self-consciously intervenes in Japan's memory-making by insisting on its truthful representation. Ishihara stresses that its script was developed through many conversations with Tome, the real-life restaurant owner, and the film was marketed as a "true story of kamikaze", blurring the fiction-reality boundary more than Firefly did. Its opening shot displays Ishihara's calligraphed message that through this film he hopes to keep "record of the Japanese as they once were". What role, then, does a Korean pilot play in this "true story of the Japanese"?

As in Firefly, Kanayama sings "Arirang" on the night before his suicide attack. But, by contrast, this key moment in I Will Go is preceded by revelation of Kanayama's inner turmoil:

All my relatives were against [my becoming a kamikaze], saying there's no reason a Korean should do so much for Japan. I wanted to show my officer uniform to my mother, who saved up so I could go to high school and not be 
looked down on ... I don't understand anything anymore. What will happen to our Korea after the war? Who and what am I going to die for, really? The only certainty is that, no matter what, I'll die tomorrow.

Whereas Firefly's Kanayama declares that he dies not for the Japanese Empire but as a proud Korean, this Kanayama, whose Korean name is never revealed, is visibly tormented and unsure what meaning his death will hold. Though touching upon his Korean identity, the scene veers towards the tragic fate of an individual caught in historical forces.

A melodramatic scene portrays him singing "Arirang" ("a song from my country") in a shaking, sorrowful voice until sobbing prevents him from continuing. Of course, in Firefly "Arirang" is also sad, but there the song carries the audience to the present, as the camera cuts from Kanayama in 1945 to Yamaoka before Kanayama's Korean relatives in 1989 and treats the song's powerful emotionality as a device to connect Yamaoka and his listeners and push towards reconciliation. In contrast, I Will Go's Arirang episode merely serves as one of the film's many tragic stories of kamikaze pilots. Each pilot anguishes over his fate, though personal circumstances differ. Kanayama's Korean identity simply becomes another sentimental variant. At scene's end, the camera cuts from Kanayama's sobs to those of a young woman whose pilot lover is about to launch, implying equivalence between their tragedies.

Unlike Firefly, which leaves Kanayama's motivation inaccessible, thus retaining his Otherness, I Will Go explains away Kanayama's actions in more universal terms as those of a young man wanting to make his mother proud. More problematically, even though becoming a kamikaze was hardly a matter of free choice, the film implies that Kanayama willingly went beyond his duty as a colonial subject, despite his relatives' objection that a Korean should not do "so much" for Japan.

I Will Go cites Kanayama's Korean identity only to reabsorb his Otherness into the story of the Japanese nation. The discrimination suffered by Kanayama highlights instead the kindness of his fellow pilots and of Tome, who goes out of her way to look after him, even selling her kimono to buy eggs to make his favourite dish. On the night before his suicide mission, Kanayama reminisces about how well Tome has treated him "even though" he is Korean: "I've never met someone so nice in Japan. When I'm here [in Tome's restaurant], I forget that I'm Korean. You've looked after me with loving kindness for so long, even more than my parents did. Thank you". The film consistently represents Tome as a woman of kindness and conscience, who at times goes against the Japanese military in order to look after the young pilots, especially Kanayama. Unlike Tome in Firefly, who after the war admits her guilt in supporting it ("We sent them off, waving the Rising Sun Flags and saying it's for the country.... We killed them"), I Will Go's Tome is separated from the inhumanity of the Japanese military, always siding with the pilots as a compassionate maternal figure.

After the singing of "Arirang”, Kanayama's Korean identity is no longer visible. Once back at the airbase, he is identical to other members of his unit, all 
of whom wear uniforms with the rising sun headband and armband. When a sick comrade begs to be taken along to his final mission with the rest of the unit, the captain tells him that they, implicitly including Kanayama, will be waiting for him at Yasukuni. ${ }^{7}$ A shot captures farewell poems written by the unit members on a Rising Sun Flag; Kanayama's reads, “Once I was just a weed growing between rice paddies, but now that I've been chosen as a kamikaze, I have become a cherry blossom". This poem, glorifying and aestheticising kamikaze, written by a Japanese pilot, is here attributed to Kanayama. As the kamikaze set their bloody fingerprints on their farewell poems as a pledge, Kanayama's earlier despair is replaced by his commitment and determination as a unit member.

In Kanayama's filmic self-sacrifice for Japan despite his origins, Korean identity intensifies sentimentalism. As Benedict Anderson has argued, dying for one's country assumes a "moral grandeur" and an "aura of purity and disinterestedness" (1991: 144), because a nation is a community that one does not choose. For a Korean to die as a kamikaze for Japan and to accept a fate even crueller than for a Japanese, can be treated as especially tragic and "beautiful".

The final scene completes the erasure of Kanayama's Korean identity. Many years after the war, the sole survivor, Nakanishi, pushes Tome's wheelchair along a path surrounded by cherry trees. Suddenly, fireflies appear from nowhere and turn into images of pilots who had died during the war, Kanayama prominent among them. Smiling and waving, they run towards Tome and Nakanishi. At first speechless, but then visibly overcome with emotion, Tome and Nakanishi repeat "thank you" and "we owe you" as the pilots' images fade and disappear, still smiling. Framed in cherry blossoms, fireflies, and scenery reminiscent of Yasukuni, the images construct the pilots as a unified entity evoking the nation. Tome's narration that "they were all wonderful, beautiful young men" concludes the film and renders the kamikaze an object of gratitude and commemoration. Black and white snapshots of real kamikaze, including Tak Kyung-hyun, accompany the credit roll, underscoring the film's "true history".

I Will Go thus aestheticises kamikaze death and accepts it as meaningful to post-war Japan, in contrast to Firefly, which resists nationalising kamikaze as either brave heroes or tragic victims. I Will Go finds affinity with then newly appointed Prime Minister Abe's statement that year that Japan's prosperity rested on the precious sacrifice of young kamikaze pilots (Abe 2006: 107). At a time when the Education Act was being revised to promote patriotism, the film's message of beautiful sacrifice looks towards justifying a future mobilisation of citizens into war. Such a nationalist framework ultimately dissolves the subject position of a Korean kamikaze into the homogenised and lionised camaraderie of those who sacrificed their lives for future Japanese.

\section{Conclusion}

Made six years apart, Firefly and I Will Go insert different voices into Japanese war memory. Firefly encourages desire for reconciliation over nostalgic commemoration of kamikaze, a popular trope in their post-war representation. 
In Firefly, kamikaze are neither pure national heroes nor victims. By contrast, I Will Go rearticulates the story of Tak Kyung-hyun in a national and sentimental framework, incorporating the Korean into a narrative of "beautiful young men" and "heroic and beautiful Japanese people in the past". In short, the two films judge necessary action differently: Firefly aspires for reconciliation, while I Will Go pushes towards memorialisation that supports the present agenda of patriotic education.

Firefly is clearly the more sophisticated film. Eschewing the usual construction of the past to reinforce contemporary national identity, it envisions a reconciliation that resists closure on the past's meaning and interrupts current perpetrator-victim dichotomies. Such an approach, while risking the charge of overlooking Japanese colonial violence, has the merit of potentially releasing Japanese and Korean imaginations from competing essentialist nationalisms. By highlighting the ambiguities of colonial subjects fighting under the Japanese Empire, Firefly challenges both Japanese nationalist narratives and Korean interpretations that label its kamikaze pilots as national traitors.

Both films engage the changing political environment of twenty-first-century Japan. In 2001, the protracted shift from left-liberal pacifism to neo-nationalist revisionism was in its early stages. Firefly intervened in contemporary debates about Japan's past and its future direction by introducing a Korean kamikaze for the first time in Japanese film history. By the time I Will Go appeared in 2006, however, the neo-nationalist backlash had progressed, and relations between Japan and Korea had deteriorated. I Will Go's memory-making both responded to and helped constitute such an environment, as it reinforces revisionist vindications of Japanese imperialism that claimed Koreans and Japanese were treated equally. Firefly's narrative, which attempts a cultural sensitivity that supports desire for reconciliation, was thus overwritten by the seamlessly nationalistic $I$ Will Go - a direction that the 2013 blockbuster kamikaze film, Eternal Zero, also pursues. That kamikaze narrative in Japan has since grown even thicker and solidified into national memory of unparalleled fortitude and tragedy, reflects an era of rising nationalistic sentiments.

Despite such an environment, where Japan-Korea relations seem entrenched in conflict, it is important to remember that the boundary between collective identities is a product of discourse. It is not absolute. The figure of Korean kamikaze offers a space for thinking about such aspects and exploring historical memory beyond rigid identity politics and outside the binaries of pure victim and pure victimiser.

\section{Notes}

1 Yamaguchi (2010) is the most comprehensive study of Korean kamikaze currently available in Japanese.

2 With the exception of Toho's war-time propaganda film Ai to chikai (Love and Pledge, 1945), which glorified a Korean kamikaze pilot volunteer to mobilise Korean youths into Japan's war, Firefly is the first Japanese film that depicted a Korean kamikaze pilot. 
3 I refer to him as Kanayama throughout this chapter, though his Korean name, Kim Songje, is revealed in a climactic scene.

4 South Korea lifted its ban on Japanese popular culture gradually from 1998, but at the time of Firefly's filming, interaction between the two remained limited.

5 All translations in this chapter are my own.

6 This point is reinforced by having Kanayama played by a Japanese actor.

7 Tak Kyung-hyun, the model for Kanayama, is enshrined in Yasukuni, with a special display at the adjoining Yushukan museum that notes his Korean origin.

\section{References}

Abe, Shinzo. 2006. Utsukushii kuni e [To a beautiful country]. Tokyo: Bunshun Shinsho. Anderson, Benedict. 1991. Imagined Communities. London, New York: Verso.

Bae, Yongme and Nogi Kaori. 2008. "Chōsenjin tokkōtaiin o dō kangaeru ka [Perspectives on Korean Special Attack Corps]". Rekishi-chiri kyōiku [History, geography, education], no. 733. August.

Caruth, Cathy. 1996. Unclaimed Experience. Baltimore: Johns Hopkins University Press.

Dew, Oliver. 2016. Zainichi Cinema. London: Palgrave Macmillan.

Fukuma, Yoshiaki and Yamaguchi Makoto. 2015. Chiran no tanjō [The birth of Chiran]. Tokyo: Kashiwa Shobō.

Furuhata, Yasuo. 2001. "Chiran de yomigaetta tokkōtaiin tono kōryū no kioku [Chiran visit brought back memories of interaction with Korean Special Attack Corps members]". Bōsei [Hopeful star], 32 (9) no. 378: 38-43.

Herman, Judith. 2015. Trauma and Recovery. New York: Basic Books.

Igarashi, Yoshikuni. 2007. "Kamikaze Today", in Ruptured Histories, edited by Sheila Miyoshi Jager and Rana Mitter. Cambridge, MA: Harvard University Press: 98-120.

Inuzuka, Ako. 2016. "Memories of the Tokko: An analysis of the Chiran Peace Museum for Kamikaze Pilots". Howard Journal of Communications, 27 (2): 145-166.

Kanazawa, Makoto. 2001. "Soshite, hotaru wa maiorita [Then, a firefly flew down] 1". Kinema junnpō [Cinema journal], no. 1329: 82-85.

Kwon, Hak Jun. 2017. "Changes in Perception of Korean Commandos in Korea”. Ritsumeikan sangyō shakaironshū [Ritsumeikan social sciences review], 52 (4): 67-81.

LaCapra, Dominick. 2001. Writing History, Writing Trauma. Baltimore and London: Johns Hopkins University Press.

Morris-Suzuki, Tessa. 2013. "Heroes, Collaborators and Survivors", in East Asia beyond the History Wars, edited by Tessa Morris-Suzuki, Morris Low, Leonid Petrov, Timothy Y. Tsu. London: Routledge. 164-189.

Nakamura, Hideyuki. 2017. Tokkōtai-eiga no keifugaku [Genealogy of Special Attack Force cinema]. Tokyo: Iwanami Shoten.

Noji Tsuneyoshi. 2014. "Sengo hatsu no kankoku roke sakuhin [The first post-war film shot in Korea]". Nikkan gendai [Daily gendai], 27 December. www.nikkan-gendai. com/articles/view/geino/156050.

Sakamoto, Rumi. 2015. "Mobilising Affect for Collective War Memory". Cultural Studies, 29 (2): 158-184.

Sato, Tadao. 1974. "Tokkōtai-eiga no keifu [Genealogy of Special Attack Corp cinema]". Shinario [scenario], September: 82-87.

Seaton, Philip. 2018. "Kamikaze Museums and Contents Tourism". Journal of War \& Culture Studies, 12 (1): 67-84. 


\section{Rumi Sakamoto}

Sobchack, Vivian. 2004. Carnal Thoughts. Berkeley, Los Angeles, London: University of California Press.

Taylor-Jones, Kate. 2017. Divine Work, Japanese Colonial Cinema and its Legacy. New York and London: Bloomsbury.

Yagi, Hidetsugu. 2001. "Hansen eiga ni shitate rareta 'Hotaru' [Firefly was made into an anti-war film]". Shokun [You], 33 (9): 160-164.

Yamada, Kazuo. 2007. "Sono shunkan karera wa mada ikiteita [At that moment they were still alive]". Zen'ei [Avant-garde], September. no. 821: 73-83.

Yamaguchi, Takashi. 2010. Tasha no tokkō [Special attack by the Other]. Tokyo: Shakai hyōronsha.

Yoshida, Takashi. 2014. From Cultures of War to Cultures of Peace. Portland, Maine: MerwinAsia.

Yoshida, Yutaka. 2008. "Sensō to tokkōtai [War and Special Attack Corps]". Rekishi chiri kyōiku [Historoy, geography, eduction], no. 733: 10-17.

Yoshida, Yutaka et al. 2014. "Ima towareru chōsenjin 'tokkōtaiinn' no mondai [Korean "Special Attack Corps members" as a current issue]", in Nikkan rekishi kyōdō kenkyū purojekuto dai 15-kai, dai 16-kai shinpojiumu hōkokusho [Japan-Korea collaborative history research project, reports of 15th and 16th symposium], edited by Nikkan sōgo ninshiki kenkyūkai [Research group on mutual perceptions of Japan and Korea]. Kunitachi: Nikkan sōgo ninshiki kenkyūkai. 114-126.

\section{Filmography}

Hotaru [Firefly]. 2001. Directed by Furuhata Yasuo [DVD]. Tokyo: Toho.

Ore wa kimi no tame ni koso shini ni iku [I Will Go and Die for You]. 2007. Directed by Shinjō Taku [DVD]. Tokyo: Ore wa kimi no tame ni koso shini ni iku seisaku iinkai. 


\title{
6 Memories of comfort
}

\author{
Postcolonial production and \\ consumption of Koreeda Hirokazu's \\ Air Doll (2009)
}

Kukhee Choo

\section{Introduction}

In 2006, as part of its Content Industry Promotion Policy to endorse Japanese popular culture globally, the Japanese Ministry of Economy, Trade and Industry (METI) initiated the UNITJAPAN J-Pitch programme in order to bolster film industry participation in international co-productions. This short-lived programme supported filmmakers to pitch ideas to foreign investors, to attend film development workshops, and to host international co-production seminars at prestigious film festivals such as those at Cannes, Berlin and Hong Kong. ${ }^{1}$ Directors well recognised in international circuits like Koreeda Hirokazu were heavily promoted under the J-Pitch initiative. Koreeda's films, such as Maboroshi (1995), After Life (1998), and Nobody Knows (2004), had regularly screened around the world up to that point; Nobody Knows took a major prize at Cannes in 2004 when its male protagonist Yagira Yūya won the Best Actor award. ${ }^{2}$

In May 2009, Koreeda showcased Air Doll (Kūki ningyō), his seventh narrative feature film, at Cannes, and the film was released in Japanese theatres in September the same year. Unlike his previous works, Air Doll was a product of significant trans-Asian collaboration: the title role was played by Bae Doona, a Korean actor who had already achieved fame for her performances in Bong Joon-ho's Barking Dogs Never Bite (2000) and The Host (2006), and Park Chanwook's Sympathy for Mr. Vengeance (2002); Lee Ping-Bin of Taiwan, known for his work with auteur directors such as Hou Hsiao-hsien and Wong Kar-wai, served as cinematographer. The international acclaim that Koreeda, Bae and Lee had already attained meant that Koreeda's Air Doll garnered considerable attention at film festivals, ${ }^{3}$ a platform that often features films made by well-known auteurs but does not necessarily guarantee profits (Peranson 2008: 32). ${ }^{4}$

Despite its mediocre box-office performance, Air Doll's provocative subject attracted much interest among viewers in Japan and elsewhere. Online responses to the film in Japanese appeared split by gender; those with female names expressed more positive attitudes towards the film and often discussed universal emotions shown by the characters, whereas male-named commenters tended to focus on the film's sexual aspects. In one extreme case, a self-identified male blogger wrote that the film's subject was sadomasochism gone awry, concluding 


\section{Kukhee Choo}

that the male protagonist's death shows "it is not safe to practice S\&M with a naïve person who is not familiar with it". ${ }^{5}$ Additionally, many Japanese comments criticised Koreeda's casting of Bae, a Korean, which I will discuss more later. In contrast, many foreign critics praised this choice. On the popular website for Japanese cinema reviews, MidnightEye.com, Tom Mes (2009) writes:

In Air Doll she is magnificent, and not only for her sex appeal: she combines such contradictory traits as innocence, eroticism, cuteness, vulnerability, and inhuman outlandishness all into a single performance - traits that most actors would have trouble expressing individually. There may be a few Japanese actresses capable of pulling off the role ... but the added fact that we know Bae is Korean only helps set the character apart from all those around her.

However, missing in Mes's review, I argue, is awareness that Bae's Korean identity also renders her a body full of historicity in a postcolonial context. Yoshikuni Igarashi has analysed how the body was constructed as a site of ideological struggles and nationalistic reinforcements during colonial Japan (Igarashi 2000). Similarly, Bae, the only identifiable Korean entity in the film, in performing the role of a sex doll, inevitably carries the historical and ideological associations of how Korean women were treated and viewed by many Japanese during and after the colonial period.

In addition to responses from film critics and bloggers, both domestic and abroad, Koreeda's film has also garnered scholarly attention. Je Cheol Park analyses Air Doll from the perspective of new Japanese communities that Koreeda imagines in an era of neo-liberalism and neo-national backlash. Drawing upon psychoanalysis, Park sees Air Doll as a critique of neo-liberal economics that calls for building new forms of relationships. Park argues that although the film's emphasis on shared communal bonds might come across as "didactic or moralistic" (Park 2011: 180), Air Doll offers new imaginations and enjoyment to the Japanese audience as well as survivors of the post-bubble economic recession and the national trauma of the 1995 Hanshin earthquake and Aum Shinrikyo sarin gas attack (ibid.: 167). Michelle Cho also utilises psychoanalysis to conceptualise Air Doll's body "as the site both separating and linking fantasy and reality" through the notion of "disenchanted fantastic" (Cho 2015: 227). The desire to identify with others leads to a failed projection process, a misrecognition that results in Air Doll's tragic ending. Cho concludes that:

Air Doll revises the categories of human and nonhuman by defining the human as that being who displays the symptomatic tendency to use fantasy to disengage from a shared social reality. In other words, humans share a common inhumanity, treating others as objects of use and consumption, the logic of which involves the limited recognition of the other as an element of fantasy, a projection of desire.

(Ibid.: 236) 
Thus, while Park looks to new forms of community-building, Cho examines the failed connection of humans in the film. Within another spectrum that draws upon Martin Heidegger's ontological analysis of tools, Kristopher L. Cannon interrogates the relationship between humans and objects in Air Doll and asserts that "tool-oriented interpretation of objects limits our understanding about the lives of things" (Cannon 2016: 268). Cannon argues that Koreeda's film not only challenges spectators' anthropocentric expectations, but also encourages them to expand their conceptualisation of things, especially when viewing the female protagonist's transition from plastic doll to human body and hearing the sound of her moving plastic or breathing. Unlike Park, Cho, and Cannon, who focus on the film text, my approach encompasses a broader social and historical perspective. In particular, I scrutinise the director's decision to adapt a manga text but to steer away from the original imagery and create a film replete with anime otaku ("geek") ${ }^{6}$ stylistics such as maid costumes, while casting a famous Korean actor as a sex doll, at a critical juncture in the national J-Pitch programme amidst the Cool Japan initiative. ${ }^{7}$

In this chapter, I analyse differences between the original manga story and Koreeda's film in the broader framework of not only soft power competition between Japan and Korea, but also postcolonial politics and the comfort women issue. I argue that the transnational production of Air Doll raises important questions about the multifaceted nexus of regional producers, trans-Asian collaborators, and local and global consumers. Koreeda's film challenges the notion of trans-Asian cinema in an era of borderless film production, yet evokes the postcolonial and neo-liberal nationalist conflicts and tensions that the region has witnessed over the past two decades with the rising competition and interplay of popular cultures between Japan and South Korea as they have each achieved global recognition.

\section{Air Doll (film) vs. Küki ningyō (manga)}

Air Doll, based on the 20-page manga short story Küki ningyō by Gōda Yoshiie, published in 2000, is a story of an inflated sex doll that develops a soul. The title character (Bae Doona) lives in the house of a lonely middle-aged man, Hideo (Itao Itsuji), who names her "Nozomi" ("desire" or "wish" in Japanese). Hideo speaks to Nozomi and treats her like a living partner; he eats, strikes up conversations, bathes, and has sex with her. While Hideo works as a restaurant server during the day, Nozomi comes to life and explores her Japanese neighbourhood. Nozomi takes a job at a video rental store, where she falls in love with a male co-worker named Junichi (Iura Arata), who discovers her true identity when he blows air into her body after she has accidentally punctured herself. Junichi accepts Nozomi as she is, and Nozomi's emotional struggle between her dual roles as blow-up sex doll and ordinary female in love becomes the focal point of the narrative. One day Nozomi comes home and finds a new, upgraded sex doll in Hideo's bed. In order to confront Hideo about his new doll, Nozomi reveals that she is "alive", terrifying him. Nozomi leaves Hideo's apartment and visits 
Junichi. They consummate their love, and Junichi repeats the act of deflating and inflating Nozomi's body. ${ }^{8}$ Nozomi wants to reciprocate what she sees as Junichi's affection, and punctures his abdomen in the hope of similarly blowing air into his body, which results in his death. Nozomi decides to end her existence by releasing her last breath (or Junichi's breath) in a dumpster while people in the neighbourhood wake up to a new morning, sharing the same air.

The narrative and character development in Air Doll deviate significantly from the original Küki ningyō text. In the manga, Nozomi's name is "Jun" (written with the kanji character "pure") and her love interest Junichi is "F-Oh" (the letter "F" hyphenated with the kanji character "husband", pronounced as "Oh"). In contrast, Hideo only appears once in the manga and is nameless. Jun is portrayed as a mature female who interacts with her surroundings in a contemplative and affectionate manner. She is aware of her role as a non-human sex toy, yet she is not dismayed and feels happiness seeing flowers in her neighbour's yard, a dog with her puppies, and the blue sky. Her heart is as pure as her name indicates. Furthermore, except when at home naked in bed, Jun is dressed in conservative attire consisting of a long coat, long skirt and a buttoned-up shirt. In other words, Jun is depicted as a sexual gratification tool with an unadulterated tender soul. As noted by Roger Matthews, female sex workers are often depicted in media as having a "heart of gold" to erase negative realities associated with the occupation (Matthews 2008: 36). Jun's counterpart F-Oh is depicted as a lonely, timid male who fabricates tales of sexual escapades to his friends. However, unlike Jun's owner, who seeks superficial gratification through sex dolls, F-Oh is portrayed as cheerful, yet innocently shy towards Jun. When Jun's body becomes deflated at the video store, F-Oh, in panic, blows air into Jun to revive her, rather than being scared of her for being "non-human". Touched by F-Oh's acceptance, Jun offers herself to him, but he rejects her sexual invitation, which confirms him as a "nice guy" who does not take advantage of Jun's vulnerability. In a sense, F-Oh himself, an emasculated outsider, mirrors Jun's "heart of gold". Jun decides never to inflate herself again with a pump, even if it causes her death, in order to preserve F-Oh's breath, or "air", in her. She discovers that having a "heart" (kokoro), and falling in love, can lead to being "in pain" (setsunai). When Jun's owner discards her after he purchases a new sex doll, Jun ends up in a dumpster, wrapped in a transparent garbage bag. The final panels show Jun gazing up at the sky and appreciating its deep hue. This admiration, Jun thinks, is possible because she has a "heart".

The original manga depicts Jun as an "average" Japanese female, contemplating daily life in a Japanese manner in Japanese. The title Küki ningyō thus renders Jun's character a localised Japanese figure who tries to find even small happinesses in her confined neighbourhood. In striking contrast, Koreeda's film adaptation, which features Bae, a non-Japanese, as the female protagonist, makes the dynamics and subjectivity transnational. To put it differently, the transformation of Japanese Kūki ningyō into transnational Air Doll evokes a questionable postcolonial objectification and consumption of a Korean female body by the director, producers, and the Japanese as well as global audiences. To understand 
Koreeda's adaptation of Air Doll and the consequences of casting Bae Doona, one must take into account both the larger historical context of the Korea-Japan relationship and how Japan positions itself vis-à-vis the West. By casting Bae Doona as Air Doll, Koreeda's film transforms a story of a sex doll within a Japanese context into a text that prompts a peculiar postcolonial predicament: the presence of Bae can readily evoke the tension between former coloniser and colonised for international film audiences. What is more, the differences between the original manga and the film adaptation and their ramifications can be analysed on three levels: first, the film's visual representation as catering to global fandom of Japanese popular culture; second, as an example of Cool Japan versus Korean Wave soft power competition, and, third, in terms of the unresolved historical comfort women issue that manifests itself in media culture.

\section{Air Doll and the global fandom of Japanese popular culture}

Koreeda's selection of a manga text that depicts a stereotypical male otaku fascination along with his addition of a maid outfit for Bae's character can appear as an endeavour to appeal to, or indulge, global heterosexual male audiences. In contrast to the manga, Koreeda's film emphasises his signature visual aesthetics rather than offering narrative explanations of how Nozomi interacts with the world. Koreeda's famous long takes detail Nozomi's exploration of her neighbourhood, sometimes focusing on her facial expressions as she witnesses daily interactions. Unlike the manga, which provides Nozomi's internal monologues, the film invites audiences to fill in gaps in constructing the meaning of "air" in relation to Nozomi's existence. Although the paucity of speech in the film can be attributed to the vision and stylistics of Koreeda, who is known for his wideangle shots, parsimonious dialogue, and slow pacing, his alteration of the manga protagonist is visually provocative. In addition to changing all the characters' names, Koreeda has Nozomi always appear either naked in bed or dressed in a French maid outfit (Figures 6.1 and 6.2).

The Japanese government's global promotion of Japanese popular culture makes it pertinent to scrutinise Koreeda's use of the maid image, which evokes particularity in a Japanese cultural context as the image is often associated with Japanese manga and anime characters as well as Akihabara's "maid cafes". Treating a sex doll as human is often associated in Japan with otaku culture, in addition to its notable consumption of manga, anime, video games, maid cafes, and participation in costume play. Although of course not all male Japanese otaku have interest in sex dolls, Western media outlets have regularly focused on cases of Japanese men fascinated with them, as in a 2007 Reuters report on a 45-year-old engineer named "Ta-Bo" who possessed nearly 100 sex dolls:

[Voiceover] Ta-Bo often watches television with his toys before bathing them, powdering them so that their skin feels more human, dressing them in lingerie and then taking them to bed. "A human girl can cheat on you or betray you sometimes, but these dolls never do those thing [sic]. They 


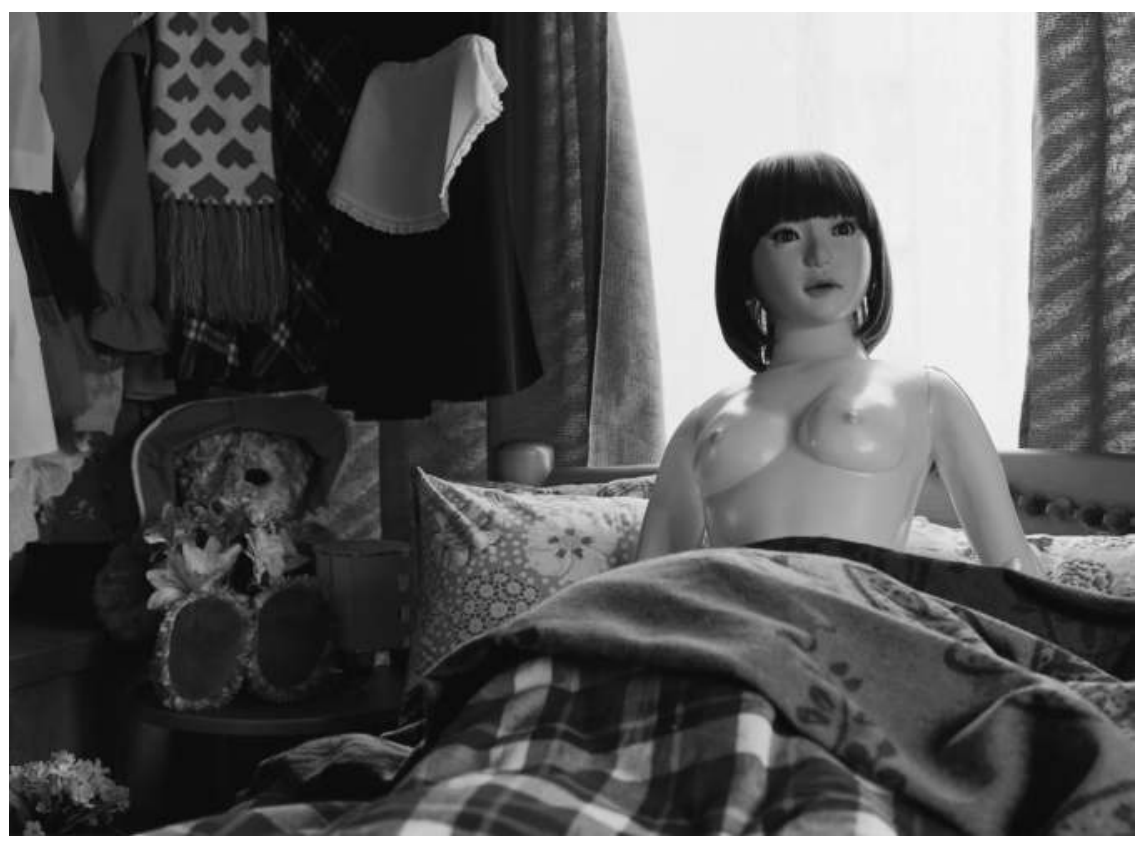

Figure 6.1 Inflated sex doll Nozomi in her owner Hideo's bed.

Source: (C) 2009 Yoshiie Gouda/Shogakukan/AIR DOLLProduction Committee.

belong to me 100 percent", says the engineer who has spent more than 2 million yen $(\$ 16,000)$ over the past decade on the dolls.

(Reuters 18 July 2007)9

Even a decade later, news reports highlighting the "fear" that Japanese men have over a relationship with real women have continued in Western news outlets. ${ }^{10}$ In short, sex dolls have become associated with Japan's otaku culture, particularly in the Western imagination.

Over the past two decades, however, the image of otaku in Japan has changed significantly (Choo 2012: 98-99). Researchers such as Patrick Galbraith have proposed that otaku male sexual desire towards two-dimensional manga and anime characters challenges heteronormative masculinity (Galbraith 2015), which in turn empowers the otaku. However, one can argue that otaku masculinity is no longer marginalised and has in fact become mainstream, at least vis-à-vis Western otaku consumers, under the Japanese government's promotion of Cool Japan. In fact, the Japanese government has already established otaku culture as a key component of Japan's economic future, as the production and consumption power of otaku, the revenue earned from the content industry is at par with that of Toyota's automotive industry (Choo 2012: 83), and the Cool Japan initiative has facilitated a global spread of otaku culture. ${ }^{11}$ However, as I have discussed elsewhere (Choo 2018), 


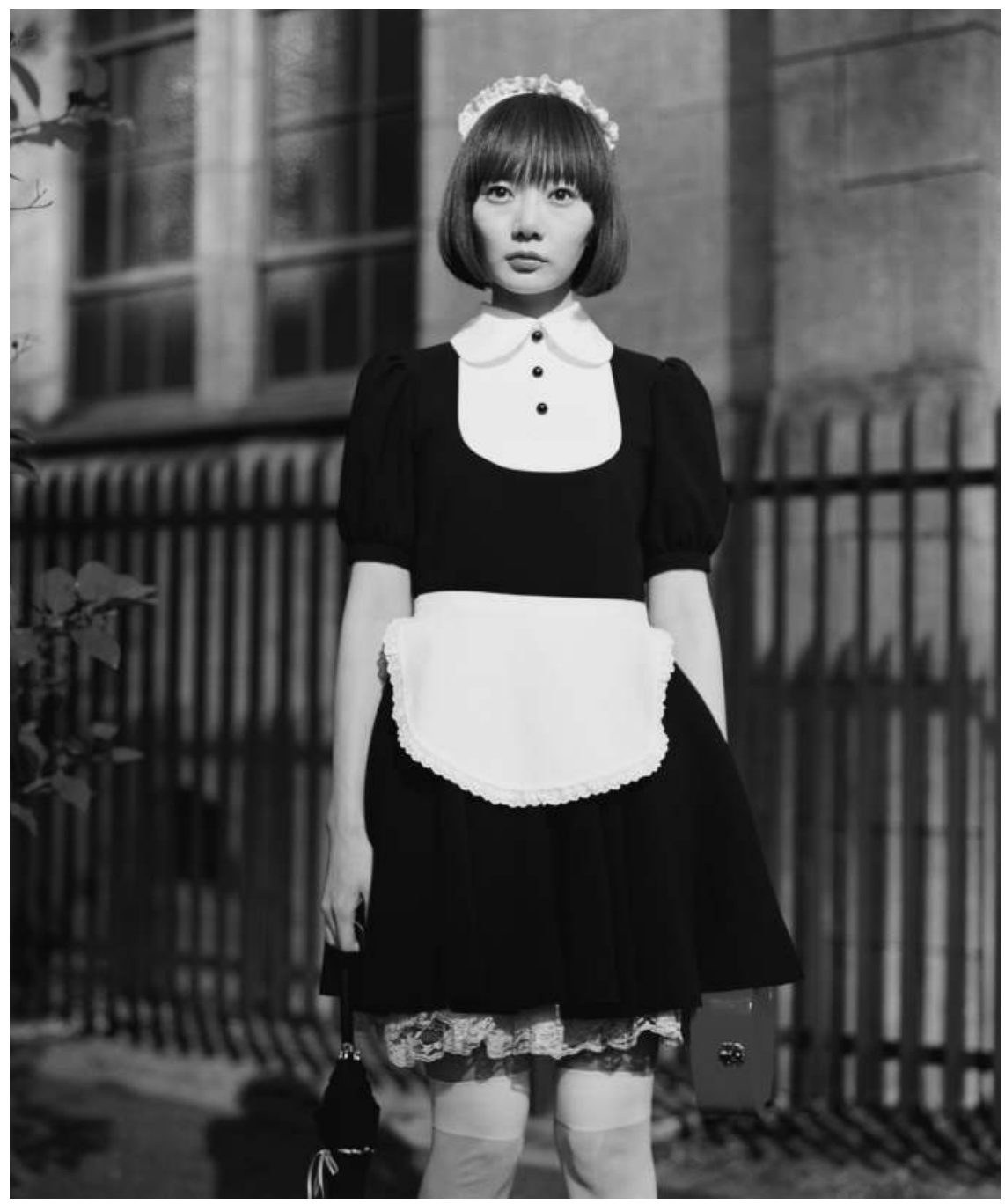

Figure 6.2 Nozomi exploring her neighbourhood.

Source: (C) 2009 Yoshiie Gouda/Shogakukan/AIR DOLLProduction Committee.

the Japanese government's promotion of Cool Japan draws on a problematic gender configuration where female bodies are often sexualised to gratify the imagined homogeneity of Western otaku audiences. Consequently, the global popularity of manga and anime, especially in Western markets, makes Koreeda's depiction of a sex doll replete with stereotypical otaku imagery a focal point of critical attention. In addition to being an international auteur filmmaker, Koreeda inevitably became a Cool Japan director through Air Doll. 


\section{Bae Doona, caught in soft power competition between the Korean Wave and Cool Japan}

When Bae Doona appeared on Japanese television in 2009 to promote Air Doll, she was often introduced as "Hallyu actress Bae Doona" (Figure 6.3). Hallyu, the Korean Wave, became a formidable force in Asia from the early 2000s and has come to be recognised around the world.

Japan enjoyed close to a decade of active Hallyu coverage in its media since the breakthrough popularity of television drama Winter Sonata (2002) in 2004. However, this excitement came to a sudden halt in 2012 when NHK, the public television broadcast station, announced that it would not allow South Korean competitors on its annual end-of-the-year singing contest, Kōhaku utagassen. Even before NHK's decision, Japanese media had been slow in acknowledging the popularity of South Korean culture outside of Asia. For example, Japan was the only developed country that lacked awareness of South Korean singer Psy's Gangnam Style as a massive global hit in 2012. ${ }^{12}$ John Lie argues that the reason the song received scant attention in Japan was because the video for Gangnam Style lacked appeal for K-pop fans in Japan; its cheesy dancing and gauche stylistics went against the grain of the dominant Hallyu trope in Japan that featured high-skilled dance moves performed by beautiful singers (Lie 2014: 60). Gangnam Style was, in fact, heavily played throughout Tokyo at major shopping areas and clubs at the time, but the song's popularity was not highlighted in Japanese media as it was elsewhere around the world. Therefore, the perception that Gangnam Style was not popular in Japan is based on its deficient media coverage, not the actual circulation or consumption of the song.

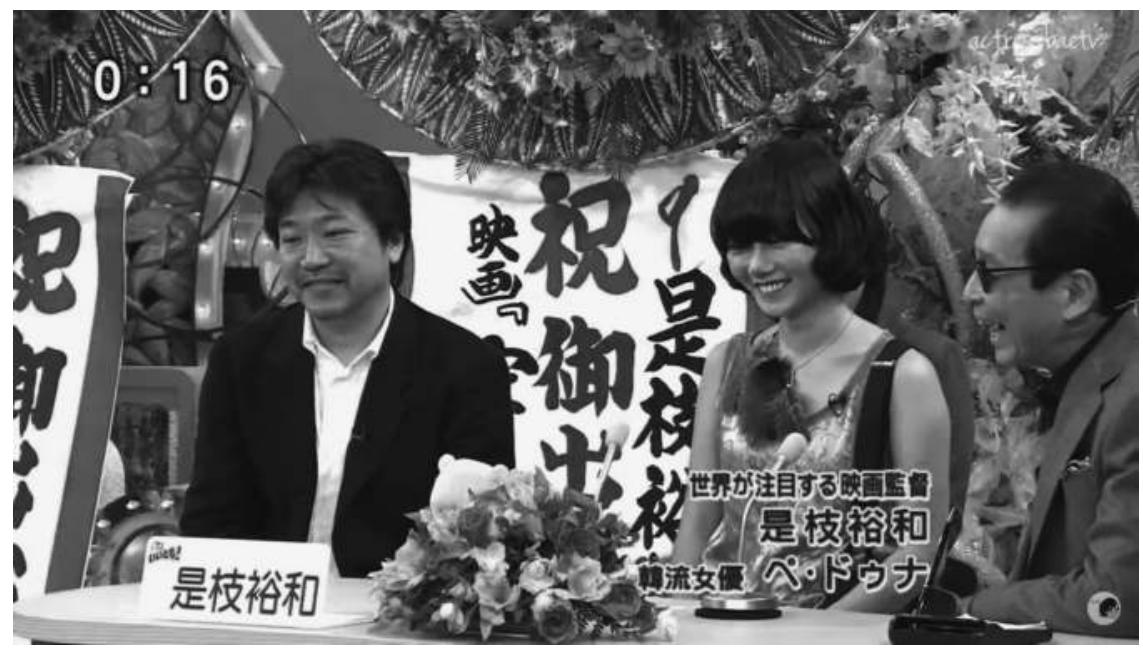

Figure 6.3 Bae Doona and Koreeda Hirokazu appear on the popular television show Waratte iitomo with the host Tamori on 14 September 2009. The caption reads "Hallyu actress Bae Doona." 
Similarly, Korean dramas became popular in Japan rather later than other countries in the region. It has been noted that Hallyu officially began in Asia with the success of the television drama What is Love All About? in 1997 (Shim 2006: 28). However, Hallyu only entered Japan with the explosive popularity of television drama Winter Sonata (2002). The male protagonist of Winter Sonata, Bae Yong-jun, won a massive following in Japan, a phenomenon known as the "Yon-sama" boom, from Bae's Japanese nickname. ${ }^{13}$ Bae appeared in various Japanese commercials and became imagined as the major heartthrob for middleaged and older Japanese housewives. Following the success of television dramas, South Korean films also broke into the Japanese market starting with Tae Guk Gi: The Brotherhood of War (T'aegŭkki hwinallimyŏ, 2004; titled Burazāhuddo [Brotherhood] in Japan), which featured Jang Dong-gun and Won Bin, both popular actors in South Korea known for their attractive physical features. The movie, set during the Korean War, was viewed by 13 million people in South Korea, over a quarter of the population. When Jang and Won arrived in Japan on 16 June 2004 to promote the film, over 2,000 fans greeted them at Narita Airport, creating heavy congestion. ${ }^{14}$

In the years immediately thereafter, one could witness a nearly unidirectional influx of South Korean male actors into the Japanese market; female counterparts were not as successful. ${ }^{15}$ Although female protagonists from popular dramas like Winter Sonata, Dae Jang Geum (2003), and Hotelier (2001; with a 2007 Japanese remake) were invited on Japanese television programmes, none achieved the same popularity in Japan as their male counterparts. In other words, when Hallyu established a foothold in the Japanese market, it was a masculine wave, and has remained more popular among female consumers than men. Thus, as Japan's otaku culture, which often utilises the female body, was spreading overseas, South Korean popular culture was rooting itself in Japan through Korean male bodies. Even if Hallyu's slowness in entering Japan may have resulted from a nationalistic stance by Japanese media, the logic of capitalism deemed Korean male bodies worthy of consumption by Japanese women, in particular older women who saw in Winter Sonata "the pure passion for love and caring in human relationships which according to them, they used to have in their youth", and felt a nostalgia related to the loss that accompanied Japan's rapid post-war modernisation (Iwabuchi 2008: 248).

Although scholars such as Sun Jung assert that Korean male entertainers popular abroad typically were pretty "flower-boys" (kkonminam) who drew on non-threatening soft masculinity (Jung 2011), Hallyu's flow of Korean male bodies was also perceived as a hard masculine invasion, and generated backlashes around Asia. For example, the Japanese media often featured figureheads who scoffed at Korean drama consumption as the frivolous pastime of "middleaged housewives" (Mori 2008), online Chinese discussion boards filled with voices that condemned South Koreans for claiming authority over Chinese territories, culture and food, ${ }^{16}$ and Taiwanese male rappers sang in expletives against Koreans (Yang 2008: 202-203). In short, Hallyu was viewed as a cultural threat. In Japan, serious attacks against Hallyu and Koreans emerged. The two-volume 


\section{Kukhee Choo}

2005 manga Hate Korean Wave (Kenkanryü), each of which sold around 340,000 copies, depicts an "innocent" male college student in Japan who once liked Koreans, but grows to find them reprehensible after learning the "truth" about Korea's culture, history and ethnic characteristics. ${ }^{17}$ The narrative takes a defensive stance towards the historical tensions and colonial past between Japan and Korea, Korean diasporic communities in Japan, and the Korean Wave. Readers are positioned within a "victimised" masculine nationalist framework as the story asserts that South Korea's economic success was a result of colonialisation by Japan, and in extension the Korean Wave itself owes its success to Japan. Rumi Sakamoto and Matthew Allen argue that Japanese nationalism during the 1990s took on new forms through popular culture:

[Japan constructed] explicit enemy figures, in particular, China and South Korea ... one major factor behind the increasing influence of nationalist ideas in Japanese society and among youth in particular is the availability of widely accessed subcultural artifacts such as manga (comics) and Internet bulletin boards. Popular culture can be an effective means for transmitting political messages.

(Sakamoto and Allen 2007: 2)

In short, Japan's contemporary online and popular culture nationalistic narratives show "fear" of losing out in global economic competition to its neighbours, whose rise is viewed as threatening Japan's economy, although Japan's ongoing recession began in the early 1990s, before South Korea and China solidified their global market position. As also witnessed in the hyperbolic nationalist fervour against South Korea in the summer of 2019, Japanese nationalism emphasises competitiveness, rather than collaboration, with these two countries.

\section{Comfort women 2.0}

Given Japan's competitive nationalism, it is worth noting that Air Doll was produced at the height of Hallyu, but not released until the initial wave in Japan eased. Bae Doona had been known for her comical, emotionally exaggerated, and often asexual performances. In 2005, Bae performed in the Japanese film Linda, Linda, Linda (dir. Nobuhiro Yamashita) as a high school exchange student from South Korea who joins an all-girl rock band. Her character's awkward command of Japanese and lack of awareness of local cultural codes positions her as a rather comical "Other". Her performance in Linda, Linda, Linda is in line with her previous unconventional and often "asexual" roles in Korean films. However, surprisingly, Koreeda has stated in interviews that he could envision nobody else but Bae in the role of Air Doll (Schilling 2011: 18). He has professed to being a fan before casting her, and with the encouragement of Bong Joon-ho, who directed Bae in Barking Dogs Never Bite (2000) and The Host (2006), approached her. ${ }^{18}$ Bae was hesitant about this role in a Japanese film that required full nudity, and sought advice from Old Boy (2003) director 
Park Chan-wook, who told her that she should act in any Koreeda film "no matter what" (mujogon). ${ }^{19}$ This report suggests a network of internationally recognised Asian male film directors supporting each other and sharing resources, here, a female actor.

Striking is Koreeda's response to an interview question about whether Japanese mainstream female actors would have played Nozomi:

I didn't even think about casting a Japanese actress. Frankly, I don't think a Japanese actress today could have played this part. I was simply a fan of Doona Bae's work in her Korean films like Take Care of My Cat and Barking Dogs Never Bite. I thought she was terrific in these films, and I had wanted to work with her for some time, even if I knew it wouldn't be an easy dream to realise due to language barriers. But for this role, the main character begins with a very basic grasp of the Japanese language, so I thought she could play it, even if it would be a little difficult in the beginning.

(Hartzheim 2010)

As the two Korean films that he mentions in his answer do not feature Bae in a sexualised manner, his determination to cast her as a sex doll, even before considering any other Japanese female actor, is curious. Both Koreeda and Bae denied that casting her in the role of sex doll, a non-human subject, had any connection to comfort women, the sex slaves for the Japanese military during the Second World War. On the international stage, Bae supported Koreeda's dismissal of the comfort women issue:

Air Doll is not a feminist film. There were no additional thoughts behind it, politically or morally.... Film is not politics but art. As a Korean, I can't forget what happened in the past, but [Korea and Japan] need to like each other on a cultural level. ${ }^{20}$

According to a Korean news report, however, in an interview held at the Cannes Film Festival in 2009, Koreeda admitted to pondering the subject of comfort women when he cast Bae, but then explained that no Japanese could have performed the role, although he did not elaborate on whether this was due to reluctance or lack of talent. ${ }^{21}$ In fact, most actors in Japan would eagerly have worked on Koreeda's film owing to his international reputation. However, the conventional stance of Japanese female actors established in the industry is not to take heavily sexualised roles. For example, Izutsu Kazuyuki, who had directed Sawajiri Erika in the popular film Pacchigi! (2005), commented with dismay upon seeing her in such a role in Helter Skelter (2012), "I feel that she has been used". Izutsu's rare, openly disheartened declaration suggests the stigma in Japan against female actors performing in highly sexualised roles. Therefore, from the Japanese film industry's point of view, finding an A-list Japanese female actor corresponding to Koreeda's stature for a role full of nudity was perhaps 


\section{Kukhee Choo}

unlikely. ${ }^{22}$ Why, then, did Koreeda not cast a non-major Japanese female actor as Nozomi, the comfort sex doll? His decision to hire a Korean thus leads to the question of how non-Japanese Asian female bodies are viewed and consumed in Japan and how they can become associated with the comfort women issue.

Refusing critical historical or political contemplation, both Koreeda and Bae urge viewers to subscribe to their own historical oversight, the amnesic or deliberate insensitivity that casting a female actor from a former colony into the role of a sex doll may evoke complicated emotions and questions among viewers. Furthermore, Koreeda hyperbolically praised Bae in the Japanese media, perhaps to assuage the negative reception she might meet in Japan due to the film's extensive nudity. By appearing in a Japanese film aimed at Western festivals that utilises Cool Japan references of maid outfits and sex dolls, a common aspect of Western fascination for Japan's otaku popular culture, Bae becomes consumed as a fetishised sexual fantasy that is showcased to Western audiences under the market logic of Cool Japan, a role that, ironically, few Japanese female actors would have been willing to perform.

Although Koreeda may have expected international viewers to consume his film without referencing historical events between Japan and Korea, the emotional investment associated with the past appears entrenched on both ends. Small pockets of South Korean media and netizens voiced concerns that the film may "suggest" gender dynamics associated with comfort women. ${ }^{23}$ However, no South Korean news sites or weblogs offer comments against the film as harsh as some found on Japanese website 2channel, where much vitriol was directed against Bae, as a Korean, playing the female protagonist:

"I thought it would be interesting, but as soon as I knew that the protagonist was a Korean, I lost all interest".

"[She] isn't supposed to be seen as human so isn't it appropriate?"

"It attests to the director's amazing strength for casting a 'person who imitates to be human (hitomodoki, referring to Koreans)' as a doll who is not human".

"[Koreeda] must have thought that it would have been impossible to cast a real 'human' to play a doll in a realistic manner".

"Indeed, a doll is not human. And the Chōsen (Korean) pseudo-human is not 'human.' Therefore, to play the role for this doll is basically impossible for Japanese humans to perform". ${ }^{24}$

The above statements are replete with enduring Japanese biases against Koreans, motivated by historical stigma created over the colonial period (1910-1945) and beyond. Whereas such Japanese online comments reflect deep-seated racism against Koreans in Japan originating in long historical memories of war and colonialism, the South Korean media and netizens appear to have similar difficulty in distancing themselves from entrenched anger towards the Japanese for atrocities committed during the colonial period, no matter how much Koreeda and Bae deny associations with comfort women. 


\section{Conclusion}

Japanese conservatism and nationalism have become increasingly prominent since the turn of the new millennium. During the mid-2000s, former Tokyo Governor Ishihara Shintaro revived the term sangokujin ("third country citizens", a derogatory reference to former colonial Asians). Since Abe Shinzo became prime minister again in 2012, some Japanese public figures have begun to openly deny that comfort women were forced sex slaves during the wartime, and many advocate the reinterpretation of Article 9 to allow Japan to remilitarise. The economic dispute between Japan and South Korea in the summer of 2019 highlights the unresolved historical tension against the presumed mutual cultural affinity. Therefore, ignoring historicity in regard to Japanese perceptions of a Korean female body as a sex object becomes problematic. By discounting the latent historical tension between the two countries when producing Air Doll, Koreeda may have neglected the trans-Asian market while anticipating positive reception by Western audiences at international festivals. His attitude thus mirrors the Japanese government's policy, as I have analysed elsewhere (Choo 2012), of mobilising neighbouring countries' labour to participate in its culture industry to promote Cool Japan to Western markets. In other words, Bae Doona and Lee Ping-Bin were utilised as Asian labour to help promote Japanese popular culture abroad. This form of Asian film collaboration, then, would go against the contemporary trend of trans-Asian film co-production that often caters to Asian markets and allows all involved parties to prosper.

Furthermore, as noted above, the Korean Wave in Japan was oriented around masculine bodies and offered a nostalgic reminder to Japanese, mostly women, of the country's imagined past. Growing Asian economies that have not yet attained Japan's level of modernity are viewed as retaining vestiges of Japan's lost purity. Former colonies such as South Korea and Taiwan, then, exist for Japanese consumption and comfort. When they go beyond that role, they create a risk, threat, and "fear"; a fear that may lead to dire backlashes, as witnessed in the recent economic trade war and media frenzy against South Korea.

Utilising a Korean female body in a form that resembles a reconfiguration of the comfort woman relationship offers a sharp contrast to the feminine nostalgia in Japan evoked by the Korean Wave. Even though Japanese viewers unfamiliar with Bae may not know that the protagonist of Air Doll is Korean from the film posters or DVD covers, her accent in the film reveals her identity as non-Japanese. Koreeda explains in interviews that Bae's limited Japanese in the beginning of the film could be interpreted as Nozomi being like a child learning how to speak. However, her distinct accent renders Bae more akin to a non-Japanese (similar to her depiction in Linda, Linda, Linda) than a doll learning language for the first time. Bae plays the role of a non-human sex object, a role that appears to be imagined, even if in an unspoken way, within Japanese society as assigned to former colonial female bodies. ${ }^{25}$ In spite of their denials, Koreeda and Bae cannot escape the larger historical context or 


\section{Kukhee Choo}

erase their postcolonial subjectivities, especially when confronted with the neo-liberal force of the Western markets that the Japanese government and creative industries, in competition with their Asian counterparts, are so eager to please.

\section{Notes}

1 The J-Pitch lasted only a few years, disappearing altogether from the 2009 government reports, but the Japanese government's push for the creative industries to collaborate with foreign companies continues to the current day.

2 In 2018, Koreeda's film Shoplifters even received the highest honour at the Cannes, the Palme d'Or award.

3 Lee Ping-Bin won the Technical Prize at Cannes in 2000 for In the Mood for Love. Similarly, Park Chan-wook won the Grand Prize at Cannes for Old Boy (2004), and Bong Joon-ho has won awards at many international film festivals. Bae Doona, having featured in both of these directors' films, has also appeared regularly at film festivals and was subsequently cast in Hollywood films such as Cloud Atlas (2012), Jupiter Ascending (2015), and Netflix.com's original series Sense8 (2015).

4 The overall box-office take of Air Doll, according to Boxofficemojo.com, was just over US\$1.1 million, of which some US $\$ 840,000$ came from the Japanese domestic market. www.boxofficemojo.com/movies/intl/?page $=\& w k=2010 \mathrm{~W} 6 \& \mathrm{id}=$ f fKKINING YAIRDO01.

5 www.tadamonkugaiitakute.com/97.html.

6 Much research exists on the consumption, production and subjectivity of otaku in Japan. Azuma Hiroki (2001) argues that otaku consumption patterns are premised upon a "database" of visual references; Thomas Lamarre (2004) looks into the development of how otaku consumers became co-producers of the otaku movement; Saitō Tamaki (2000) psychoanalyses otaku male sexuality through their consumption of fictional "beautiful fighting girls" characters; and I discuss elsewhere (Choo 2012, 2018) how the Japanese government's Cool Japan initiative deems otaku, especially men, the bearers of Japan's economic viability.

7 The Japanese government has been promoting popular culture such as manga, anime and video games to the global market under the banner Cool Japan since 2004.

8 The way Junichi inflates and deflates Nozomi during sex recalls the sadomasochistic act of asphyxiation, where life and death intertwines with sexual pleasure.

9 www.reuters.com/article/2007/07/18/us-japan-sex-dolls-idUSSP10422420070718.

10 See, e.g. www.news.com.au/lifestyle/real-life/true-stories/looking-for-love-unhappyjapanese-men-turn-to-silicone-sex-dolls/news-story/009af6032b995a149ff0d3f5127 $058 \mathrm{~d} 1$.

11 Anime conventions have become regular events throughout the United States, Asia, Europe and South America; annual participants in Los Angeles' Anime Expo have increased from 9700 in 2000 to more than 350,000 in 2019. (See www. anime-expo.org/2019/07/11/28th-annual-anime-expo-delights-350k-fans-japanesepop-culture/.)

12 Japan's media negation of South Korea is not limited to popular culture. In 2007, when Ban Ki-moon of South Korea became the Secretary General of the United Nations, the Japanese media barely covered the story.

13 See studies by Shim (2006), Chua (2008) and Iwabuchi (2008) on this topic.

14 www.cinematoday.jp/page/A0000656.

15 Although by the end of the 2000s, popular Korean female singing groups such as KARA and Girls' Generation became popular in Japan, Korean female actors were not as visible in the Japanese market. 
16 Chinese bloggers' dissent against Korea ranges from Koreans' purported claim of Manchuria based on the Kwanggaet'o Stele (wangnŭngbi) erected in the fifth century to Koreans claiming that cold soy-bean noodle soup is indigenous to Korea.

17 query.nytimes.com/gst/fullpage.html?res=950CE0D91E3EF93AA25752C1A963 9C8B63. The manga author Yamano Sharin went on to publish three more volume in the series. The last volume, Big Hate Korean Wave (Dai Kenkanryū) was published in 2015. See Sakamoto and Allen (2007) and Chung (2015) for further studies on Japan's Hate Korean Wave phenomenon.

18 asiapacificarts.usc.edu/w_apa/showarticle.aspx?articleID=14573\&AspxAuto DetectCookieSupport $=1$.

19 www.newsen.com/news_view.php?uid=201003291213491003.

20 www.newsen.com/news_view.php?uid=200906110906391003.

21 v.entertain.media.daum.net/v/20090518182111052.

22 In other Koreeda films, well-known actors such as Esumi Makiko in Maboroshi (1995) and Ando Sakura in Shoplifters (2018) do appear nude. However, Maboroshi was the first film appearance for Esumi and her brief nudity is set in a dark-lit room. Similarly, Ando in Shoplifters is not considered a top actress. What is more, both appear nude in the film context of engaging in an endearing conversation with their partners after consensual sex, appearing as having agency and equality in terms of their sexuality.

23 www.asiatoday.co.kr/news/view.asp?seq=256142.

24 unkar.org/r/news4plus/1253936415.

25 A similar example can be witnessed in the popular Japanese television and film series Kisarazu Cats Eye (2002, 2006), where the love interest of the male protagonist (played by Okada Junichi) is a Korean female (played by Yoon Son-ha) who works at a bar while studying Japanese. The film highlights her awkward command of Japanese, in terms of both grammar and pronunciation.

\section{References}

Azuma, Hiroki. 2001. Dōbutsuka suru posutomodan: Otaku kara mita nihon shakai [Animalising Postmodern: Japanese society as seen from otaku]. Tokyo: Kōdansha.

Cannon, Kristopher. L. 2016. "Ec-Static Air: The unseeable sounds of being beside oneself”. Discourse, 38 (2): 265-280.

Cho, Michelle. 2015. "A Disenchanted Fantastic: The pathos of object in Hirokazu Koreeda's Air Doll", in Simultaneous Worlds: Global science fiction cinema, edited by Jennifer L. Feeley and Sarah Ann Wells. Minneapolis: University of Minnesota Press: 223-239.

Choo, Kukhee. 2012. "Nationalising 'Cool': Japan's global promotion of the content industry", in Popular Culture and the State in East and Southeast Asia, edited by Nissim Otmazgin and Eyal Ben Ari. London: Routledge: 85-105.

Choo, Kukhee. 2018. "Cool Governance: Japan's ubiquitous society, surveillance, and creative industries". Culture, Theory and Critique, 59 (2): 94-118.

Chua, Beng Huat. 2008. "Structure of Identification and Distancing in Watching East Asian Television Drama", in East Asian Pop Culture: Analysing the Korean Wave, edited by Beng Huat Chua and Koichi Iwabuchi. Hong Kong: Hong Kong University Press: 73-90.

Chung, Hye Seung. 2015. "Hating the Korean Wave in Japan: The exclusivist inclusion of Zainichi Koreans in Nerima Daikon Brothers", in Hallyu 2.0, edited by Sangjoon Lee and Abé Mark Nornes. Ann Arbor, MI: University of Michigan Press: 195-211. 
Galbraith, Patrick. W. 2015. "Otaku Sexuality in Japan", in Routledge Handbook of Sexuality Studies in East Asia, edited by Mark McLelland and Vera Mackie. Oxon: Routledge: $205-16$.

Gōda, Yoshiie. 2000. "Kūki ningyō [Air doll]”, in Go-da tetsugakudō [Goda's philosophy school]. Big Comics Special: Tokyo: Shogakukan: 47-66.

Hartzheim, Bryan. 2010. "Breath of Fresh Air: An interview with Kore-eda Hirokazu". Asia Pacific Arts. asiapacificarts.usc.edu/w_apa/showarticle.aspx?articleID=14573.

Igarashi, Yoshikuni. 2000. Bodies of Memory: Narratives of war in post-war Japanese culture, 1945-1970. Princeton, NJ: Princeton University Press.

Iwabuchi, Koichi. 2008. "When the Korean Wave Meets Resident Koreans in Japan: Intersections of the transnational, the postcolonial and the multicultural", in East Asian Pop Culture: Analysing the Korean Wave, edited by Beng Huat Chua and Koichi Iwabuchi. Hong Kong: Hong Kong University Press: 243-264.

Jung, Sun. 2011. Korean Masculinities and Transcultural Consumption: Yonsama, Rain, Oldboy, K-Pop idols. Hong Kong: Hong Kong University Press.

Lamarre, Thomas. 2004. "An Introduction to Otaku Movement". EnterText: An Interactive Interdisciplinary E-Journal for Cultural and Historical Studies and Creative Work, 4 (1): 151-187.

Lie, John. 2014. "Why Didn't 'Gangnam Style' Go Viral in Japan? Gender divide and subcultural heterogeneity in contemporary Japan”. Cross-Currents: East Asian History and Culture Review, 3 (1): 6-31.

Matthews, Roger. 2008. Prostitution and Public Policy. Oxon and New York: RoutledgeCavendish.

Mes, Tom. 2009. “Air Doll”. Midnight Eye. www.midnighteye.com/reviews/air-doll/.

Mori, Yoshitaka. 2008. "Winter Sonata and Cultural Practices of Active Fans in Japan: Considering middle-aged women as cultural agents", in East Asian Pop Culture: Analysing the Korean Wave, edited by Beng Huat Chua and Koichi Iwabuchi. Hong Kong: Hong Kong University Press: 127-142.

Park, Je Cheol. 2011. "Envisioning a Community of Survivors in 'Distance' and 'Air Doll' '. Film Criticism, 35 (2/3): 166-186.

Peranson, Mark. 2008. "First You Get the Power, Then You Get the Money: Two models of film festivals". Cineaste, 33 (3): 23-37.

Saitō, Tamaki. 2000. Sentō bishōjo no seishin bunseki [Psychoanalysis of beautiful fighting girl]. Tokyo: Ōta Shuppan.

Sakamoto, Rumi and Matthew Allen. 2007. 'Hating 'The Korean Wave' Comic Books: A sign of new nationalism in Japan?" The Asia-Pacific Journal: Japan Focus, 5: 10. apjjf.org/-Rumi-SAKAMOTO/2535/article.html.

Schilling, Mark. 2011. "Kore-eda Hirokazu Interview”. Film Criticism, 35 (2/3): 11-21.

Shim, Doobo. 2006. "Hybridity and the Rise of Korean Popular Culture in Asia". Media, Culture \& Society, 28(1): 25-44.

Yang, Fang-chih Irene. 2008. "Rap(p)ing Korean Wave: National identity in question", in East Asian Pop Culture: Analysing the Korean Wave, edited by Beng Huat Chua and Koichi Iwabuchi. Hong Kong: Hong Kong University Press: 191-216.

\section{Filmography}

Kūki ningyō [Air Doll]. 2009. Directed by Koreeda Hirokazu. Tokyo: Engine Film, Bandai Visual Company, TV Man Union, Eisei Gekijo, Asmik Ace Entertainment. 
Part III

Japan-Korea relations and popular culture manipulations 


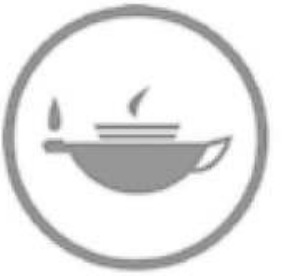

Taylor \& Francis Taylor \& Francis Group http://taylorandfrancis.com 


\title{
7 The Diary of Yunbogi and \\ Japan-Korea relations
}

\author{
Chris Perkins
}

\section{Introduction}

In 2006 a new "complete version" of The Diary of Yunbogi was published by the Japanese publisher Hyōgensha. The book's obi - a belt around the book that displays material designed to entice readers - proclaimed: "Japanese and South Koreans both cried! The complete edition of the 'Korean Wave Boyhood Diary"'. The back cover tells us this diary was written between 1963 and 1964 by Yi Yunbok, a South Korean boy in the fourth year of primary school in Daegu, and that his account of life suffered in abject poverty brought Japan to tears. ${ }^{1}$ The front cover's pen and ink drawing shows Yunbogi sitting on an outcropping above Daegu, a bucket hanging from one hand. On the back the same figure - thin, dirty, dressed in rags - stands with bucket in hand, staring back at us blankly.

The Diary of Yunbogi, first serialised in the Korean newspaper Donga Ilbo in 1964, was a massive success in the Republic of Korea (ROK) and made into three films, the first of which (Sorrow Even Up in Heaven, dir. Kim Soo-yong [Kim Suyong]) won Best Film at the 1965 Blue Dragon Film Awards. The Japanese version of the diary, translated by Tsukamoto Isao and published by Taiheisha in 1965, was the first South Korean book published in Japan and met with great acclaim there; by year's end it had gone into 11 editions (Murata 1965). Later that year, pre-eminent Japanese New Wave director Ōshima Nagisa produced a short film based on the text. In 1992, a two-volume manga version of the diary was published before we finally arrive at the "complete version" in 2006. The Diary of Yunbogi lives on the Japanese Library Association basic books list, and is recommended by the Japanese Ministry of Health, Labour and Welfare.

This chapter approaches the diary, and its subsequent adaptations, as sources and sites for imagining the complex social and political relations between Japan and the ROK, especially at the moment of normalisation of relations in 1965. I see the diary and its retellings as examples of the mediation of South Korea: attempts to close the geographical and moral distance between Japan and Korea shaped by the technologies used in the process (Chouliaraki 2006: 19-20). Korea in Japan's national imaginary was, at the time of publication of The Diary of Yunbogi, 


\section{Chris Perkins}

ambivalent. Before the Second World War, Korea lay within Japan's empire spatially, but lagged temporally; Koreans were citizens of Japan, but were thought to need stewardship from Japanese and were among the first to die for Japan's needs. After the war, concerted efforts were made in Japan to remove Korea from the national imaginary. Until 1951 the two nations ignored each other's existence (Lee 2011: 433), and after the division of the Korean peninsula, Japan recognised diplomatically neither the DPRK nor the ROK until 1965. There was very little guilt towards Korea in the Japanese public consciousness, and at least until 1952 significant support existed for deporting Koreans in Japan who "disturbed the peace" (Tonomura 2014: 57). As the effects of Japan's high-growth economy started to make themselves felt from the mid-1950s, attitudes towards Koreans softened, but Korean residents of Japan remained effectively stateless until normalisation. Normalisation, when it came, was only partial, and many in Japan, especially on the Left, decried the lack of recognition for North Korea and further integration into the US anti-communist security alliance in East Asia. Thus, this diary was key to early reimagining in Japan of the newly visible South Korea.

Importantly, Yunbogi's story is one of suffering: the diary is about poverty, pain and Yunbogi's abandonment by both his mother and South Korean society. Thus, the dynamics of suffering are key to the relationship between nations facilitated by this diary. In analysing mediations of suffering, Chouliaraki (2006: 85-95) identifies two broad categories, representations and orientations, both of which have implications for how the relationship between nations is constructed. Representations encompass relationships of space and time between viewers and those viewed. Are those being represented distant or close, is their experience coeval with the viewers or trapped in the past, is the future pre-determined or open? Orientations, on the other hand, draw attention to agency: what kind of voice do the sufferers have? Are they humanised? What are the ethics of communication between viewer and viewed? The answers to these questions all involve essential components of the role of this diary in Japan-Korea relations.

The career of Yunbogi's diary reveals the complex dynamics of victimisation and victimhood developing after the Second World War. Here I argue that The Diary of Yunbogi created affective linkages between the ROK and Japan, tying the two together through emotion while smoothing over complicated politics of aggression and victimisation and that the diary moved Japanese commentators, especially on the Left, to review their interpretations of post-war US hegemony in East Asia, and identify with South Koreans as fellow victims of imperialism. While the diary created an imagined community of emotion and victimhood, and thus connected the two nations, it simultaneously asserted a temporal difference between them by flagging Korean backwardness. Perhaps paradoxically, this backwardness was framed in positive terms. Unlike previous Japanese discourses on Korea that defined it as needing Japan's guiding hand to modernise fully, Yunbogi, and by extension the ROK, now represented humanistic innocence and a moral exemplar for a Japan lost in the grips of rapid economic growth. This sentiment played into Japanese unease over the pragmatic "economism" that was fast becoming a political consensus in 1960s Japan. 


\section{Yunbogi in the ROK}

In the prologue to the 2006 edition of The Diary of Yunbogi, Tsukamoto recounts his first trip to the Korean peninsula. After learning some Korean from Zainichi Koreans in Japan, he made his way by boat to Busan before spending two weeks at a Korean friend's house in Daegu, where he was struck by the number of children he saw living on the streets. When confronted by a local journalist who wanted to know his true impressions of South Korea, Tsukamoto remembers replying: "Now that I've arrived in South Korea I'm surprised. The cities are dirty, there are many 'Yunbogis': it's like Japan 15 years ago" (Yi 2006: 4).

In 1965 the ROK was starting to feel the effects of economic policies instigated by Park Chung-hee, who had taken power in a military coup in 1961. Park was heavily influenced by his experience with the Japanese during the colonial period, and on taking power adopted a Japanese-style top-down approach to economic mobilisation. Through import protection and export promotion, as well as an industrial policy that channeled funds into chaebol business conglomerates, he oversaw the industrialisation and modernisation of the South Korean economy. But as Tsukamoto's observation indicates, conditions in 1965 South Korea remained dire. The 1950-53 civil war had affected every stratum of society, leaving South Korea "a terribly depressing place, where extreme privation and degradation touch everyone"; a place in which "orphans ran through the streets" (Cumings 2005: 303). There were indeed many Yunbogis.

Kim Soo-yong's cinematic adaptation of the diary (Sorrow up in Heaven, 1965) captures the contradictions of these early stages of Korea's economic miracle. The film vividly contrasts inner-city, high-growth Korea and the destitute world of Yunbogi, who lives in a brick hovel "at the bottom of the hill". Yunbogi and his little sister travel between the world of dust, wells and mud floors, and the world of clubs, restaurants and bustling shopping districts as they struggle to make enough money for food by selling chewing gum, while also trying to avoid the reach of orphanages that threaten to break their family apart. Their urban experiences are grim. Yunbogi is ignored, threatened, scammed and beaten time and again, and in the film's final scenes, in which he travels to Seoul to find his oldest sister, he narrowly escapes enslavement by a gang. Apart from a few kind classmates and a teacher who eventually saves the family by having Yunbogi's diary published, the school is indifferent to their plight. Local children, dressed in the smart jumpers, shorts, and shoes of economic success, pick on Yunbogi's family because they are beggars. Kindness, when it comes, is fleeting. Overall, the film depicts a society unsympathetic, even hostile, to those left behind in the rush for economic success. All the while, Yunbogi is haunted by images of his mother, whose abandonment of the family has plunged them into destitution.

In terms of representations, the film aims at objectivity, with all but one scene displaying a documentary realism that makes judicious use of long shots to place the children within their social context. Much of the time, the camera follows the action at child's eye level, situating the viewer within Yunbogi's world as an 


\section{Chris Perkins}

equal, albeit at a slight remove. This framing is significant for spatial and temporal representation of Yunbogi. Although his hovel lies outside the city and is surrounded by signifiers of backwardness, Yunbogi nevertheless moves within the city and its institutions. His world thus overlaps with mainstream society, causing him to serve as a contradiction living within it.

Our orientations to Yunbogi are also fashioned by Kim's cinematic choices. Even when depicting Yunbogi's reveries about his mother's return, the camera maintains objectivity, refusing to occupy the same subjective space as Yunbogi even while delving into his psychological torment. We often see the children's faces in pain, but never in melodramatic close-up. Furthermore, the characters, including Yunbogi, are complex and conflicted. The sick father wants to provide for his children but cannot; he skips meals for them, but is a drunk gambler, prone to violence. The little brother is bullied by other children for being poor but is selfish and mean to his sister. The mother is both deserter and saviour. The teacher who makes publication of the diary possible engages in decisions that damage his marriage. And Yunbogi gets angry with his siblings and his father, and acts in ways that could have dire consequences for the family unit. In other words, these are complex characters trapped by circumstance. They have depth.

Combined, these techniques create a powerful humanist ethic that permeates the film. Yunbogi, despite his hardships, displays a strong moral compass going so far as to give up his meagre earnings to help an even poorer family, for which his father beats him. Yunbogi continues to attend school, write in his diary, and do his best to support his family. He has agency in this process; he overcomes obstacles and makes decisions that push the narrative forward. Indeed, the end of Kim's film is very different from the diary itself, which closes with Yunbogi informed of its publication. But in the original diary, Yunbogi does not find his sister, although it is hinted that the family knows where she might be, and his material circumstances change little. His father says that he might be able to get a job, but that's it. Kim's film, however, allows catharsis for both the characters and audience: Yunbogi, after a harrowing experience in Seoul, returns to jubilant crowds and addresses his schoolmates on a podium before being reunited with his family, mother included. Yunbogi's morality is vindicated, and salvation for his family, and for South Korea, is possible.

\section{Yunbogi travels to Japan}

With interest in South Korea reaching new heights due to the ROK-Japan Treaty, the scene was set for the diary to travel to Japan. According to Tsukamoto, the Japanese publishing company was cognizant of the diary's success in South Korea and wanted to replicate that success in Japan (personal communication 2017). The motivation for publication, however, was not solely profit. Ch'oe Yŏngdŏk, the managing editor of Taiheisha, the diary's original publisher, saw in Yunbogi a powerful vehicle for communicating about his homeland to the Japanese. Tsukamoto himself was at the time teaching Korean in Ōsaka and working on the first Japanese-Korean dictionary. When approached by the 
publishers, Tsukamoto's Korean was not sufficient to read the diary, and he spent much time consulting within the Korean community in Ōsaka to finish his translation. Tsukamoto states that he went to such lengths because he thought that "if a best seller was translated, it would prompt some understanding of South Korea and North Korea [in Japan]" (personal communication 2017). Given the paucity of Korean-language materials in Japan at the time, without Tsukamoto's efforts it is unlikely that the diary would have been published.

Furthermore, a template for the success of Yunbogi's Diary had already been established by Nian-chan (Yasumoto 2003), the diary of a 10-year-old Zainichi Korean girl in Japan published in 1958. Like Yunbogi's Diary, Nian-chan became a surprise bestseller and was made into a film by Imamura Shōhei in 1959. That year Nian-chan topped the national book sales rankings. Interestingly, Nian-chan was then translated and published in the ROK, where it also became a best-seller and set a publishing industry precedent for Yunbogi. So, while the Japanese edition of Yunbogi's Diary was packaged as a "South Korean version" of Nian-chan and promised to evoke similar emotional response, the Japanese publishers were actually following the Korean marketing approach in reverse (Muno 1965: 49-50; Asahi Shimbun, 10 August 1965: 8). This framing, however, rendered the Diary of Yunbogi a derivative work in a genre already established in Japan. In other words, Japan led with Nian-chan, and Korea followed with Yunbogi.

Commentary on the diary in the mainstream press largely framed it as an opportunity to reflect on the relationship between Japan and the ROK, although the depth of that reflection was limited to the parlous state of relations to date. The headline of the Asahi Shimbun (10 August 1965: 8), for example, "Korea's Nian-chan", used the publishers' marketing template and in doing so reinforced the temporal separation of Japan and Korea. The last paragraph of their commentary made the issue of temporality explicit by stating that the "diary calls to mind the life-styles of the Japanese at the end of the war". This point, the commentary concludes, and the fact that the diary was the first South Korean book published in Japan, "should be cause for the Japanese to reflect on a great number of things". Just what those things are, however, is left unspecified. In a more direct opinion piece about Japan-ROK relations, Murata Kiyoaki, editorin-chief of the Japan Times, characterised Japanese attitudes towards Korea as "disdainful indifference" that turned into "antipathy at the personal level". For Murata, the diary was thus an opportunity for the Japanese to discover Korea: "No doubt, tens of thousands of Japanese who read it realised for the first time that Koreans, too, are after all human" (1965: 12).

The most substantial discussion of the diary, penned by Muno Takeji, appeared in the October 1965 edition of the journal Rekishi hyōron. Muno had worked for the Asahi Shimbun during the war but resigned and moved to the countryside upon Japan's defeat in atonement for contributing to the wartime propaganda machine. Muno treats the diary as a site for articulation of war guilt and the figure of Yunbogi as a symbol for something that had been lost in Japan. His commentary also provides evidence, albeit limited, that the diary had an 


\section{Chris Perkins}

impact on how left-wing Japanese intellectuals imagined Japan's relationship with South Koreans.

Muno begins by noting that his first thought on finishing the diary was of Japan's "fatal" (chimeiteki) lack of boys like Yunbogi, not in the simple sense that Japan's rapid growth had done away with poverty, but as a commentary on the relationship between modern development in Japan and the morality of Japanese youth. Japan's economic successes had resulted in social conditions parental obsession with their offspring's academic achievement - that made children with Yunbogi's sense of justice impossible (Muno 1965: 49). Muno also stresses how the book left him thinking about colonial legacies in Korea, and Japan's lack of action on behalf of Asian neighbours it had victimised in the war. There is a palpable tension here: Japan as victimiser of Korea, and Japan as victim of its own advancement. In a perverse sense, Korea's ability to produce Yunbogi directly resulted from Japan's colonial occupation, and on this logic, subsequent economic retardation saved Korea from becoming like Japan: prosperous but morally vacuous. The logic of civilisational progress is thus turned on its head. Muno, however, shows awareness of this tension. Using the aforementioned Asahi Shimbun commentary as a starting point, he asks: "as an aggressor nation, what are we to think about the fact that the pain [of the war] which for us has become a memory, is to this day present in the victim nation?"

Muno's answer involves reimagining Japan's relationship with Asia and contains two key aspects. First, Muno offers a moral injunction to young Japanese. Through an anecdote about a Japanese youth orchestra that used a flood as a pretext to shirk performing, Muno relates how he flew into a rage and told the children that during the Korean War, North Koreans created stages deep underground and performed plays while American aircraft dropped bombs above. Muno thus implies that Japanese youth growing up amidst the 1960s economic miracle had lost a sense of both social obligation and resilience. In his reading, however, these values could be resurrected by reimagining Japan as part of Asia and exercising empathy for fellow Asians, including the Vietnamese who had now replaced North Koreans as the object of American wrath.

Muno's second point is a mea culpa that addresses Japanese reactions to the Korea-Japan normalisation treaty. Muno states flatly that, "like all Japanese with any commonsense" (50), he supports Korean unification, which means he "hates US imperialism" and deeply respects the "people of the DPRK who fought like heroes against US aggression” (51). But a consequence of this hatred, Muno recognises, was that it extended to South Koreans for bowing to US pressure. Muno expresses contrition for allowing his hatred for US imperialism to blind him to hardships suffered in the ROK as well and giving the lie to his own talk of "solidarity of the people". Muno acknowledges his ignorance of South Korea and promises to study more (51). Thus, for Muno the diary facilitated ways of relating to the people of victim nations as distinct from their governments.

Evidence also exists that the diary acted as a site in Japan for the domestic contest between North and South Korean residents. According to a contemporary ROK news source, the DPRK-aligned General Association of Korean Residents 
in Japan (Chongryon) seized upon the diary to argue that Yunbogi's experience was typical of families in the South (Choson Ilbo, 22 December 1965). The same article argues that Chongryon had instructed left-wing director Ōshima Nagisa to make a film of the diary for propaganda purposes. While the circumstances in which the film was made and screened do not support this argument, as we will see, Ōshima's film does have a strong political message that equates the world of Yunbogi with the ROK in general. It is to Ōshima's Yunbogi that we now turn.

\section{Ōshima's Yunbogi and transnational student politics}

Ōshima's version of the diary was, in his own words, his "humble message to the Korea-Japan Treaty" (1992: 101). Perhaps paradoxically, then, Ōshima also states that no plans existed to show the film in cinemas: after one private showing, the documentary would be made available to borrow on request (ibid.). In the event, The Diary of Yunbogi had a successful run at the arthouse Shinjuku Bunka theatre in Tokyo and brought in modest profit. Öshima's film is a multimodal experiment quite different from Kim Soo-yong's adaptation of the same year, and through its mediation of Yunbogi's experience the film fashions its own relationship with Korea in space and time. As commentators have noted, Yunbogi differs stylistically from Ōshima's previous documentary work (Turim 2000: 375). Visually, the film is a montage of approximately 600 photographs Öshima took on a trip to South Korea in 1964. These photographs primarily had children as their subject, which Ōshima claimed happened because the children stood out to him rather than because of a specific intention on his part (Asahi Shimbun, 2 December 1965: 12). The photos were then assembled and transferred to $16 \mathrm{~mm}$ film using stop-motion techniques, and music and sound effects were added. The film is held together by quotes from the diary spoken in Japanese by a child actor and narration by an unidentified Japanese man, which includes passages addressed to Yunbogi directly.

An obvious reason for this innovation was necessity: Ōshima only decided to adapt Yunbogi as a film after returning from Korea, and so had to make use of the material at hand (Yomiuri Shimbun, 27 November 1965: 12). But he also appears to draw inspiration from contemporary currents in avant-garde filmmaking, particularly the work of French photographer and filmmaker Chris Marker, who had been introduced to Ōshima by television producer Ushiyama Junichi in the mid-1960s (Turim 2000: 375). Marker had himself documented South Korea in his 1957 photobook Coréennes (Korean Women), which he dubbed an "essay-film", and later in his science fiction short La Jetée (1962) he pioneered a photo-montage approach to filmmaking (Furuhata 2012: 251; see also Turim 1998: 223-224). With Yunbogi, Ōshima seems to have appropriated Marker's photobook concept of the "essay film" about Korea and updated it using techniques Marker developed later to produce a "film-essay". Indeed, Ōshima frames his film as a "Film Document" (Firumu Dokyumento): an ambiguous category that straddles (fiction) film and (factual) documentary. 


\section{Chris Perkins}

Ōshima's writings on his time in Korea offer useful context for interpreting his version of the diary. A key theme that arises from his reflections is ambivalence over the ethics of his engagement with Korea and representing the temporality of Korea vis-à-vis Japan. In his article "Korea as I saw it", Ōshima (1992 [1964]: 61-63) repeats the trope that Korean cities resemble Japanese cities in the immediate aftermath of the war. But he also notes the concern Koreans have for how they are represented in Japan: "when I told Koreans with whom I became acquainted that I was there to gather material for television, most - from government officials to filmmakers, from journalists to bar hostesses - asked me not to photograph or mention poor or dirty areas" (ibid.: 61). Across his writings Öshima notes his cognizance of and respect for the national pride behind these requests from Korean informants, especially given the shame of Japanese colonisation and the painful reality for Koreans of Japan's rapid economic rise after the war. Representing the poverty that he witnessed would perpetuate the temporal logic of a Japan that leads, and a Korea that lags. Ōshima argues, however, that achieving peace requires dismantling the "framework of that national consciousness". The ethical injunction for the filmmaker is thus to "always seek the truth and communicate it" (ibid.: 62), and - as with Muno's revelation - only when Japan comes to know Korea properly can the two establish a positive relationship.

It seems, however, that the truth that Ōshima wanted to communicate was tied to Korean poverty. The majority of the film's photographs depict impoverished children, covered in grime and wearing frayed clothing. We are shown frame after frame of shanty towns, dirt roads, children with babies on their backs, and oil drums used for collecting water and cooking. Unlike Kim Sooyong, who placed the children within the context of rapid urban economic growth, Ōshima dwells on their destitution and the backwardness of their surroundings. The film thus represents the ROK as firmly in the past, with little hint of economic development. The photographs' style contributes to this effect by recalling the work of early post-war documentary photographers such as Tanuma Takeyoshi, Hayashi Tadahiko and Kimura Ihee. The aesthetics of the film place Korea not only in the past, but in Japan's past. The choice of photographs has an impact on the agency of the children presented on screen, as they stand frozen, unable to move the narrative forward. The extracts from Yunbogi's diary are read, but rather than having a narrative thrust, they simply inform the audience of Yunbogi's grim reality. The act of writing the diary, ironically the one thing that gave Yunbogi power over his own life, is omitted from the film.

The adult Japanese male narrative voice in the film addresses Yunbogi directly, sometimes expressing back to Yunbogi what the child has narrated in the diary excerpts, at others asking questions related to Yunbogi's circumstances. What is particularly interesting, however, is the development of an authorial voice for this narrator. The first few minutes of the film involve interplay between Yunbogi and the narrator. A diary section is read, then the narrator retells a simplified version to Yunbogi. Through this potentially redundant process of repetition, the narrative voice begins to take on a sense of 
omniscience, stating what is seen and heard in the plainest terms possible. It does so without emotion. As with the photographs, viewers are presented with reality, enhancing the film's documentary-like effect (Lichten 2012: 9). Significantly, it is a Japanese voice that becomes authoritative and pushes the film forward. This voice takes agency away from the Korean children and enables Ōshima to move the narrative, and, with it, Yunbogi's future in new directions.

Once the authority of the narrative voice is established, its argument starts to rearrange Yunbogi's diary into a story about war and oppression. Unlike Sorrow Up in Heaven, Öshima links the poverty we see through the photographs to the Korean War early on. Yunbogi is interpellated as an orphan of the war, in that the stresses and strains that caused his mother to leave and his father to become an alcoholic arise from structural factors rather than inescapable human flaws. As such, Yunbogi is told not to blame his father for their situation. His father is a victim too. But the story of victimhood does not start and end with the Korean War. Ōshima also steps away from Yunbogi's narrative to link his story to a two-fold oppression, Japanese colonialism and the succession of post-war dictatorships, that each boil down to state-militarism. In a powerful metaphor, the narrator tells us about the curfew in South Korea. Asking what happens if you are caught on the streets after curfew, the narrator tells us:

And what would you do if you're caught?

Say "I'm a dog, woof"

"I'm not a human. Woof".

"So please overlook me. Woof".

"Saying this, walk on all fours".

"Nothing to be ashamed of, as you live a dog's life after all".

All this is delivered in the narrator's matter-of-fact voice: a voice that, as has been established, makes authoritative statements about reality. State-militarism in the ROK has reduced the Koreans to the level of animals living on the streets. But the story is not a simple attempt to elicit empathy from a Japanese audience. It is a rhetorical device that creates connections and makes warnings.

At this point the temporal work of Öshima's film becomes complicated. The obvious connection here is between oppression in the ROK and in pre-war Japan. So far, so simple: Korea continues to lag behind Japan. But another temporal layer is added when we think about the context in which Japanese audiences watched Yunbogi. In 1965, Japan's economic miracle was in full swing, having been launched five years earlier with Prime Minister Ikeda Hayato's Income Doubling Scheme. However, Ikeda's economic pragmatism was essentially a method of steering the Japanese public away from unresolved issues concerning the war, fascism, democracy, and Japan's place within the emerging political order: issues that came to a head in the massive, and inconclusive, demonstrations in 1959 and 1960 against the renewal of the US-Japan Security Treaty, known in Japan as the Anpo Protests. But while Ikeda's scheme, and spectacles such as the 1964 Tokyo Olympics, were cementing economic 
consensus, the spectre of Japan's wartime militarism still loomed large in public consciousness. Thus, although the stories of oppression in Yunbogi lived ostensibly in Japan's past, they also served as a reminder that militarism, oppression, and the destruction of human dignity still existed in the present.

In fact, Japan's aggression towards Korea is used in the film to construct a future orientation for Yunbogi and the children he represents. In conjunction with a section in the diary that recounts Yunbogi's impressions of South Korea's Liberation Day, the narrator speaks as follows:

36 years of domination.

36 years of exploitation.

36 years of oppression.

36 years of massacres.

His voice is accompanied by the sound of jackboots marching and dissonant strings that add to the tension. Images of peasants working in villages amongst grass huts create an impression of a pure countryside life, rooted in an indeterminate past, destroyed by Japanese persecution. While the jackboots march on in the background the narrator continues:

A paper that was forced out of existence in 1940 proclaimed:

"Boiled down, red peppers become even hotter,

And wheat, once dead, sprouts anew.

Boiled down, red peppers become even hotter,

And wheat, once dead, sprouts anew.

Yi Yunbogi, you too are a boiled-down red pepper.

Yi Yunbogi, you too are wheat that, once dead, sprouts anew".

Here we learn more about Ōshima's message to the new ROK-Japan Treaty. Later, the film shows images from the 19 April Student Revolution of 1960 that forced Syngman Rhee out of office. The narrator notes that South Korean youth go either into the military or to university, and that university students were instrumental in bringing down Rhee's government. As viewers see images of the protests, the narrator asks Yunbogi whether he will someday throw stones. The montage continues, and Ōshima shows us the child who has substituted for Yunbogi. He then zooms back into his face. The shot lingers and we hear shouting, screaming, running. Yunbogi is now witnessing the protests, looking at his future. Again, in contrast to Kim's film, which grants Yunbogi agency and, thus, hope within the current structure of the ROK, Ōshima suggests that the only way forward for the youth of Korea is, as in Japan, to protest violently against the state.

These pictures of protest also tie together Japan and the ROK through a shared photographic aesthetic of memory (cf. Perkins 2015). Although released five years after the Anpo Protests, Ōshima's images would have no doubt resonated with Japanese who had either taken part in the demonstrations or seen 
news coverage that documented them. Through this shared imagery a visual argument emerges that victimhood binds Koreans and Japanese because they live under oppressive states. Thus, while the film acknowledges Japan's oppression of Korea, it also forges a transnational link through radicalism: both nations labour under governments that must be resisted through direct action.

So, even if Chongryon did not engage Ōshima to make the Diary of Yunbogi, he does not offer a rosy picture of life in the ROK. Indeed, some newspaper commentary on the film took Ōshima's use of Yunbogi as a symbol for the ROK and exploited it. In a discussion of the film, the Yomiuri Shimbun (27 November 1965: 12), for example, ran the headline: "Painting the reality of South Korea through 'Yunbogi's Diary", , arguing that "the diary captured the reality and sentiment of the Korean people". The article makes clear the nature of this reality: "In extreme poverty, starving, his mother and sister gone, Yunbogi sells gum in the streets and polishes shoes".

The film also provoked criticism from filmmaker Kuroki Kazuo in the preeminent film periodical Eiga hyōron (1965), which, interestingly, focuses not on South Korea but on the political dynamics of filmmaking in Japan. Although Kuroki praises the film's structure, particularly the refrain spilling out of the screen to address the audience and the film's portrayal of child poverty, he also uses the opportunity to take radical cinema in Japan to task. For him Japanese cinema is becoming increasingly conservative, and Yunbogi does not succeed as a political film because, unlike Ōshima's maiden work, Ai to kibō no machi (A Town of Love and Hope, 1959), which Kuroki praises highly, the film does not present the audience with a vision of the future. Quoting Brecht, Kuroki argues that only when films highlight the relations of production and ownership underpinning the circumstances depicted on screen can they suggest an alternative future.

As noted, Ōshima pays little attention to the economic contradictions of the ROK in 1965, and instead pushes a message that Yunbogi's poverty results from colonial, then domestic, oppression. In the context of Kuroki's criticism, Yunbogi's agency becomes problematic: what exactly is he to demonstrate against, and what would be the desired outcome? In fashioning a transnational link between the students of Korea and of Japan, Ōshima through omission imposes the problems of Japan back on the ROK: namely, a lack of coherent radical ideology following the failure of the Anpo Protests. But there exists another interpretation of Öshima's approach to the Diary of Yunbogi, one that looks to Japan's future. As Kim Yongon argues in a 2007 article on the new Hyōgensha edition of the diary, Japan in the mid-1960s had left the "Age of Politics" (Seiji no jidai) and entered the "Age of Economics" (Keizai no jidai). South Korea in the mid-1960s, on the other hand, although beginning to enter the economic boom of the Park years, remained firmly within the "Age of Politics". As Ōshima himself said that he wanted Japanese high school students to watch his film (Asahi Shimbun, 2 December 1965: 12), he likely wished to treat South Korean students, who lived in Japan's political past, as an example that would reinvigorate the culture of protest in Japan. In this sense, contra Kuroki, Ōshima was indeed supplying a 


\section{Chris Perkins}

vision of the future of Japan, albeit one that required a trip, via South Korea, into the past. Thus, if Muno looked to Yunbogi as a source of humanistic values lost in an age of rapid economic development, Ōshima saw Yunbogi as a vehicle for returning to Japan's “Age of Politics".

\section{Conclusion}

We end where we began, with Hyōgensha's 2006 publication of the "complete" version of The Diary of Yunbogi. The diary has once again become a site for articulating a particular narrative about South Korea, Japan and economic development. Part of that narrative is directed at Zainichi Koreans. Yasuda, the man behind Hyōgensha's decision to republish the diary, is a third-generation Zainichi Korean, who wanted new generations of Zainichi Koreans to learn that even as Japan's economy boomed in the mid-1960s, their home country (sokoku) was experiencing extreme poverty. Furthermore, the book becomes regarded as a text that teaches selfish contemporary school children to think about the meaning of life via a vicarious encounter with poverty. Yasuda has also tried to refashion Yunbogi himself. Addressing the Korean Wave, he argues that South Korea has achieved its current success because of the "tough times" Yunbogi lived through (Kim 2007: 69). Yunbogi's life, therefore, is recast as an act of sacrifice for the Korea of skyscrapers seen today.

But what of that sacrifice? By all accounts the life of the original author of the diary, Yi Yun-bok, improved after its publication: he became a businessman and later a salesman and married in 1984. He continued to live with his family until he died in 1990. Ironically, however, although Yi made enough money from his diary in the ROK to get through school, he never received royalties from the publication and adaptation of his diary in Japan. In fact, not until 1985, when a Mainichi Shimbun journalist visited him in Seoul, did Yi learn that his story had provoked a huge reaction in Japan. The journalist was outraged, but Yi was philosophical: "I'm just satisfied if my book touched some people. Whether the Japanese publishing company's reward includes royalties will depend on their conscience" (The Kyunghyang Shinmun 1985).

\section{Note}

1 To avoid conflating the author of the diary and the character that was constructed in subsequent adaptations I refer to the former as Yi Yun-bok and the latter as Yunbogi.

\section{References}

Asahi Shimbun. 1965. "Kankoku no nian-chan [Korea's Nian-chan]", 10 August. Asahi Shimbun. 1965. "Tanpen eiga 'yunbogi no nikki' kansei [The Short Film 'The Diary of Yunbogi' is Completed]”, 2 December.

Chosŏn Ilbo. 1965. "Choyŏngye sŏnjŏn agyong doenŭn 'Chŏhanŭl-edo sŭlpŭm-i' iljwaikkye kamdok sik'yŏ yŏnghwahwa [The Sadness in the Sky is used for Chongryon Propaganda: Making a Movie with a Japanese Left-wing Director]”, 22 December. 
Chouliaraki, Lilie. 2006. The Spectatorship of Suffering. London: Sage Publications.

Cumings, Bruce. 2005. Korea's Place in the Sun: A modern history. London: W.W. Norton \& Company.

Furuhata, Yuriko. 2012. "Audiovisual Redundancy and Remediation in Ninja Bugeichō”. Mechademia, 7 (1): 249-262.

Kim Yon-gon, 2007. 'Mazushisa ga oshietekureru 'hontō no yutakasa.' Naze, ima futatabi 'Yunbogi no nikki' na no ka [The 'Real Wealth' Taught to us by Poverty. Why 'The Diary of Yunbogi' again?]'. Bōsei [Hopeful star], 453 (38): 64-69.

Kuroki, Kazuo. 1965. “Ōshima Nagisa no 'Yunbogi no nikki' [Oshima Nagisa's Diary of Yunbogi]”. Eiga hyōron [Film Criticism], 21 (1), 68-71.

Lee, Min Yong. 2011. "Normalisation of Relations with Japan: Towards a new partnership", in The Park Chung Hee Era: The transformation of South Korea, edited by Kim Byung-Kook and Ezra Vogel. London: Harvard University Press: 430-456.

Lichten, Jack. 2012. "Japan's Vietnam War: 1960s politics, Korea, and the US in the films of Ōshima Nagisa". AGLOS: Journal of Area-Based Global Studies (Special Issue): 1-24.

Muno, Takeji. 1965. "Yunbogi no nikki o yonde [Reading the Diary of Yunbogi]". Rekishi Hyōron [History Criticism], 182: 49-52.

Murata, Kiyoaki. 1965. "The 'Distant' Neighbors”. The Japan Times, 21 December: 12.

Ōshima, Nagisa. 1992. Cinema, Censorship and the State: The writings of Ōshima Nagisa. London: The MIT Press.

Perkins, Christopher. 2015. The United Red Army on Screen: Cinema, aesthetics and the politics of memory. Basingstoke: Palgrave Macmillan.

The Kyunghyang Shinmun. 1985. “'Chŏhanŭl-edo sŭlpŭm-i' chu-in'gong iyunbok-ssi 'k'ohŭlligae mangnae-nŭn taehak tanyŏyo [Yi Yunbok, the Basis for the Protagonist of The Sadness in the Sky says: 'My younger brother, just a little kid before, is now a university student']", 26 January.

Tonomura, Dai. 2014. " 'Nihonjin wa 'zainichi chōsenjin mondai' o dō kangaetekita ka [How did the Japanese think about the 'Zainichi Korean problem'?]” European Studies, 14: 55-59.

Turim, Maureen. 2000. "Virtual Discourses of History: Collage, Narrative or Documents in Chris Marker's level 5". Sites, 4 (2): 367-383.

Turim, Maureen. 1998. The Films of Oshima Nagisa: Images of a Japanese iconoclast. London: University of California Press.

Yasumoto, Sueko. 2003. Nian-chan. Fukuoka: Nishi-nihon shinbunsha.

Yi, Yunbok. 2006. Ano sora nimo kanashimi ga: Yunbogi no nikki [Sorrow up in Heaven: the Diary of Yunbogi]. Translated by Tsukamoto Isao. Tokyo: Hyōgensha.

Yomiuri Shimbun. 1965. "Kankoku no genjitsu o egaku [Painting the Reality of South Korea]", 27 November: 12.

\section{Filmography}

Ai to kibō no machi [A Town of Hope and Love]. 1959. Directed by Ōshima Nagisa [DVD]. Tokyo: Shochiku.

Jeo haneuledo seulpeumi [Sorrow up in Heaven], 1965. Directed by Kim Soo-yong [DVD]. Seoul: Korean Film Archive.

La Jeteé [The Jetty], 1962. Directed by Chris Marker. Paris: Argos Films.

Yunbogi no nikki [The Diary of Yunbogi], 1965. Directed by Ōshima Nagisa [DVD]. Tokyo: Sōzōsha. 


\title{
8 "Imjin River" and the transnational consumption of partitioned Korea
}

\author{
Sunhee Koo
}

"Imjin River" (Imjin'gang) is a North Korean song that depicts the Imjin River, which flows from north to south along the present-day border between the two Koreas and traverses the Demilitarised Zone. ${ }^{1}$ The music was composed in 1957 by Ko Chonghwan (1930-2002) to go with a poem by Pak Seyŏng (1902-1989); both were born in the southern half of the Korean peninsula but moved north in the turbulent years that followed Liberation. The poem evokes the river as a metaphor for the division of the nation, a nostalgic sentiment reflected in Ko's melancholy melody. A year later, distinguished North Korean soprano singer Yu Ŭn'gyŏng premiered the song to immediate acclaim, and it remains popular today in both halves of the Korean peninsula and among Koreans in Japan. ${ }^{2}$

In the late 1960s, "Imujingawa", the Folk Crusaders' Japanese-language version of "Imjin River", enjoyed popularity among university students in the Kansai area, where the Folk Crusaders were based, and students adopted it as a protest song. Along with many other protest songs, "Imjin River" became part of the soundtrack for student marches and angura (underground) movements. It even achieved regular rotation on a local radio station for about two months in 1967 (Mitsui 2013: 85). Later, in the 2000s, "Imjin River" was brought to South Korea by musicians working in popular, classical, and traditional Korean music, and, as noted, it remains well known there today.

In this study, I trace the origin and multiple adaptations of "Imjin River" in various social, cultural, and political contexts in North Korea, South Korea, and Japan. I investigate the song's attraction and viability in national and transnational consumption over six decades. Originally a song for North Koreans, "Imjin River" has gone through sonic and semantic transformations in crossing boundaries of state, nation, race, and musical genre: what are the implications of the song's adaptation, popularity, and appeal to different audiences crossculturally and transnationally? What has enabled it to transcend multiple boundaries? What does the song's trajectory suggest about the power of popular and expressive culture to blur social and racial boundaries persisting between the Koreas and Japan, a legacy of the unresolved pain of colonialism, war, and inequity in Northeast Asia? In investigating these questions, I explore music's elicitation of emotion and the polysemic nature of musical signs, and how these features lead to and reinforce the construction of community and identity. 
Inspired by ethnomusicologists Thomas Turino and Adelaida Reyes, who found the semiotic framework of philosopher Charles Sanders Peirce (1839-1914) useful in explaining the relationship between music, identity, and emotion, I also apply Peircian semiotics to an inquiry into the emotions and meanings evoked in the appreciation of "Imjin River".

Musical representation is often less "clear-cut" than other semiotic forms like language and is among the least mediated signs (Turino 1999). Indeed, almost all music leaves room for the exercise of subjectivity in its perception and interpretation. For any act of musical listening, whether in public or private space, emotion is fundamental to signification and gives music-related experience its special power. Emotion not only conveys a musical sign but also encourages individuals to make sense of what is signified by reflecting on their experiences and imagining their relationships with the sign. In this chapter, I argue that music's power in evoking themes, ideas, and sentiments enables "Imjin River" to be located along multiple musical continua beyond its original context, and to resonate with Koreans and Japanese who perceive the song in a range of musical situations.

\section{"Imjin River" in Korea}

"Imjin River" offered a revolutionary construction of North Korean communist culture with its music and lyrics, derived as they are from a poem by leftist Pak Seyŏng that signifies a North Korean identity. Pak became an acclaimed writer and composed many pro-communist lyrics, including those of the North Korean national anthem. Composer Ko Chonghwan set Pak's poem to music with a diatonic melody and a pentatonic feel in its avoidance of the fourth scale degree. Both the lyrics and music evoke the sadness of a partitioned nation and a longing for the southern part of the homeland no longer accessible to those like Pak and Ko themselves, who could never return. Its lyrics express envy of the flowing river and the birds that fly freely between the two Koreas. ${ }^{3}$ The circulation of "Imjin River" in North Korea, although not commercially driven (unlike popular songs in capitalist societies), was swift at the time of its introduction.

Much of the song's resonance derives from its lyrics. The first verse expresses longing for the South, now inaccessible ("The clear waters of the Imjin River flow down/Birds freely come and go/I long to visit my hometown in the South, but I cannot/The Imjin River flows filled with resentment"). The second describes the South as a dry land lacking agricultural abundance and the North as enriched by rice crops swaying on collective farms ("Birds sing sadly in the reed field across the river/People suffer from poor harvests and live on digging up the roots of the grass/The kolkhoz bless us with their golden rice crop/Nobody can block the river's flow and surge"). The song's text thus implies the superiority of the communist system where agricultural production is assured.

While it is hard to know how "Imjin River" was sung by singer Yu Ŭn'gyŏng at the song's premiere in 1958, given that tracking of Yu's recording is impossible from outside North Korea, a North Korean version of "Imjin River" has 


\section{Sunhee Koo}

been available on YouTube, sung by singer Cho Ch'ŏngmi (1957-), who attained fame specialising in the state's revolutionary opera. Cho was born in Japan as a second-generation Korean migrant, ${ }^{4}$ but impressed by a performance by a North Korean troupe visiting Japan, she moved to North Korea at age 16 and studied singing at Pyongyang University of Music and Dance. ${ }^{5}$ As a distinguished opera singer, Cho regularly played the heroine in P'ibada (The Sea of Blood), a representative revolutionary opera in North Korea, which earned her state recognition as kongunbaeu (distinguished performer/musician) and later inminbaeu (most distinguished performer/musician). ${ }^{6}$ Cho also served as a voice instructor at Yun Isang Institute of Music and Kimwŏn'gyun Pyongyang Music University. ${ }^{?}$

Cho's success in North Korea made her a heroic figure back in Japan, especially among Koreans affiliated with Ch'ongnyŏn, the pro-North Korean organisation in Japan, which nicknamed her Ch'ongnyŏn-ŭi ttal ("Daughter of Ch'ongnyŏn") and chaeiltongp'o-ŭi kkot ("The Flower of Zainichi Koreans"). The popularity of "Imjin River" in Japan, among both Koreans and non-Koreans alike, likely led Cho to include the song on her second VCD, Chosŏn-ŭi norae (Songs of Korea), released in North Korea in 1997. Since 1960, when the song was published in Japan by Ch'ongnyŏn in a volume of the songbook Saenorae (New Songs), designed to be used at Ch'ongnyŏn schools and community gatherings, "Imjin River" was widely disseminated and frequently sung by Koreans in Japan regardless of allegiance or affiliation. Since most Zainichi Koreans traced their origins to what is now South Korea, the depiction of a hometown in the South in "Imjin River" resonated with many nostalgic Zainichi. ${ }^{8}$

In a video for the song, Cho Ch'ŏngmi appears in white hanbok reminiscent of the uniform for girls at Ch'ongnyŏn schools, which consists of a white top and black skirt slightly shorter than usual traditional Korean dress. Her soft vocal production recalls Western bel canto singing. Considering her opera career, her voice might be seen as adapting Western classical music practice for North Korean opera. To a certain degree, the voice that Cho projects may sound like the refined voice of Western opera singers. However, North Korea's revolutionary operas emphasise themes and performance styles that manifest and reinforce the state's ideology of Juche [Chuch'e] (self-reliance), which mandates that all North Korean art be uniquely North Korean even if degrees of foreign adaptation are inevitable. North Korean pro-communist songs, in addition to their projection of propaganda, are thus performed in a resonant voice with soft timbre and smooth texture. Cho's vocals on the version of "Imjin River" available on YouTube clearly conform to such state-sanctioned sound quality.

\section{North Korean songs and self-reliance singing}

Beginning in the 1950s, Kim Il Sung emphasised the role of song in inspiring revolutionary spirit (Howard 2006: 155). Accordingly, North Korean musicians were instructed to create vocal music that encapsulates musical traits familiar to 
North Koreans and cultivates a communist ethos. Korean folksongs were infused with the "unitary ideology" (yuilsasang) on which Kim Il Sung intended to ground his state and perpetuate his authority. Around this time, ideas of Juche began to appear as an ideological underpinning in North Korea, considered as "new, emancipating and scientific" (Howard 2006: 158). In reality, however, Juche was:

[rather] anti-internationalist and anti-hegemonic, ascribing revolutionary responsibility to Kim Il Sung and interpretation to Kim Jong Il. With one eye to the Cultural Revolution then ongoing across the border, juche squares all circles: artists reflect the leader who reflects the people. Juche is normally glossed as "self-reliance", although to detractors it has been transliterated as "bloody-mindedness".

(Ibid.)

So-called Juche singing (chuch'e ch'angböp), with its soft, silky and smooth vocal style, was conceived in the 1960s, a product of North Korea's self-reliance ideology. Throughout the second half of the twentieth century, arts in the North were reshaped through merging traditional Korean forms and socialist content. The emphasis on creating a culture accessible at a mass level was reflected in new singing aesthetics. The musical inclinations of the North Korean masses were determined to be most clearly manifested in sódosori, the folksong style of the northwestern region, which was chosen to provide the foundational ingredients of Juche singing. In nationalising sŏdosori, the style was standardised alongside Soviet models, with characteristic features of traditional Korean voice removed: emotional vibrato, rough timbre, and nasal intensity were toned down if not eliminated entirely, and tritonic to pentatonic melodies were modified to fit Western diatonic scales (ibid.). Juche music (chuch'e ümak) was further consolidated during Kim Jong Il's time, when a smooth texture became the master vocal style that singers were expected to produce, beyond any specific cultural origin or musical genre. Kim Il Sung initiated Juche singing primarily to promote a local culture that would be familiar to the North Korean masses; his son Kim Jong Il took this trend further, consolidating sŏdosori into a resonant, accessible voice according to his own aesthetic preferences, in contrast with the husky, coarse timbre of traditional Korean singing.

Songs have been as important for North Korea as for other communist states, including the USSR and China, where mass song movements were instrumentalised to spread propaganda and to buttress socialist revolutions. In North Korea, simple melodies and a pentatonic and/or sentimental feel as exemplified by "Imjin River" were seen as capturing the people's familiarity with Korean folksongs as well as the early twentieth-century popular songs of Korea and other parts of Northeast Asia. In this sense, "Imjin River" offers a revolutionary construction of communist culture, with music and lyrics signifying North Korean identity. 


\section{Sunhee Koo}

\section{"Imjin River" in South Korea and Japan}

South Korea struggled under military dictatorship until the late 1980s, and "Imjin River", along with many other songs of North Korean origin or those bearing anti-government messages, was banned there until the early 1990s. As South Korea transitioned into a liberal democracy, "Imjin River" began to be heard, sung by liberal-minded musicians such as Yang Heeeun [Hŭiŭn], along with others who sang in diverse styles like Jeok Wu [Chŏk U], Kim Yongwu [Yongu], and Lim Hyungjoo [Im Hyŏngju]. The singer who contributed most to making the song widely known in South Korea and in Japan was wellestablished t'úrotŭ singer ${ }^{9}$ Kim Yŏnja, who moved to Japan in the late 1980s and established herself there as an enka singer. ${ }^{10}$ In contrast to Zainichi musicians who naturalised as Japanese and disguised their Korean ethnicity while working in Japan's popular music industry, Kim did not hide her background. While t'ǔrotŭ and enka are differentially associated with South Korea and Japan, respectively, they project similar images of old-fashioned sound, older listeners, and rurality, and are each attributed with such traditional characteristics as pentatonic melodies and characteristic vocal vibratos and note-bending. Both genres continue to be produced and performed, appealing to a broad range of age groups across each nation. T'urrotŭ and enka's associations with the past and traditional music qualities construct these genres into manifestations of a uniquely Korean or Japanese national ethos.

Despite the pro-communist message of "Imjin River", Kim Yŏnja performs the song with the original North Korean lyrics, albeit in the $t$ ' $\breve{u r o t u}$ style that she is known for in the South. Whereas "Imjin River" is sung in a silky and smooth voice in North Korea, Kim Yŏnja uses a husky voice punctuated with characteristic vibratos, a stylisation typical of t'ŭrotŭ. Although Kim does not always perform wearing hanbok, she often does so for major events or shows produced by South Korean broadcast media. Depending on repertoire and context, she occasionally performs accompanied by traditional Korean instruments. Kim's 2015 performance of "Imjin River" on Kayo mudae (Song Stage), a weekly music programme broadcast nationwide on KBS since $1985,{ }^{11}$ signified a panKorean rather than specifically North Korean identity. Kim wore colourful traditional dress and was accompanied by a Western orchestra together with traditional Korean instruments and the ongryugŭm, a zither developed in North Korea in the 1970 s and unique to that country. Kim sang original lyrics from the North in her characteristic t'urrotŭ style, using a somewhat unrefined voice in a low register with a lot of vibrato. ${ }^{12}$ Kim's vivid manifestation of emotion, markedly more pronounced than other South Korean singers' versions of the song, made the performance striking. Her ability to project intense feeling on stage perhaps accounts for her success in Japan, where enka is measured by a musician's ability to evoke sentiment in the audience.

Perhaps aware of different expectations in South Korea and Japan, Kim Yŏnja performs "Imjin River" differently in the two countries. In Japan, Kim sings lyrics in Japanese and intensifies the delivery of heightened emotion. ${ }^{13}$ 
As Christine Yano (2002) points out in her study of enka, the genre's primary attraction lies in its ability to elicit tears in fans, who imagine that these sentimental songs embody a Japanese ethos and consider their reaction uniquely Japanese. Enka, as summarised by Yano, equates to the consumption of tears.

Deborah Shamoon has also pointed to an imaginary of uniqueness in enka for Japanese audiences. She traces the genre's emergence to the post-Second World War milieu, when Japan needed to rebuild the nation while resisting the US occupation: "While the genre of enka is both sincerely nationalist and obviously a modern, artificial construct, its roots are deeply tied to colonial ideology, namely, the attempt to create a new kind of Japanese music that sounded authentic and non-Western" (Shamoon 2014: 114). Thus, behind the construction and consumption of enka lay the circumstances of post-Second World War Japan and the influx of American culture. The genre's tears make sense to its Japanese fans through semantic chains triggered by a music signifying old Japan, post-war reconstruction and experience, and sadness, which taken together are seen as constituents of Japanese collective identity. Both Shamoon and Yano point out that enka feeds the notion of Japan as unified through the power of sentimental song, inviting fans to imagine Japan's collective ethos. In this regard, Kim Yŏja's "Imjin River" fits the enka market with little difficulty.

Kim's Japanese version of "Imjin River", drawing on lyrics by Yoshioka Osamu, refers to the river as a mother and expresses the hope of the separated coming together under that mother: "It's hard to hold on to endless dreams forever/Wondering if our mother river knows it or not/Our only wish is to be reunited". In Kim's performance, the specific Korean experience of Cold War trauma and a partitioned nation is translated into more generic content for Japanese enka fans. Themes of separation, nostalgia for one's hometown, and a missing mother appear in many enka songs whose lyrics manifest longing for furusato (hometown) or haha (mother), and thus evoke namida (tears). The song's melody, in a diatonic scale with a strong pentatonic feel due to its avoidance of the fourth note and rare use of the seventh, also is typical of enka, whose melodies are often built on yonanuki (missing the fourth and seventh scale degree) major or minor pentatonic scales.

Kim Yŏnja's distinctive treatment of "Imjin River" in South Korea and Japan illustrates how a musical sign may be restylised to evoke identities that different communities can relate to, by interpreting sonic, lyrical, and emotional signifiers in terms of their own experience. Kim's renditions of "Imjin River" depart from the North Korean version in her overtly dramatic performances reinforced by vocal production that conforms to a rough or dynamic t'ürotŭ or enka style and new lyrics for the Japanese version. As an enka singer, Kim obviously works to elicit sentiment in her performances of "Imjin River" for Japanese audiences, such as in her 2001 appearance at NHK's famous New Year's Eve music contest, Kōhaku utagassen (Red and White Singing Contest), where the song was introduced by its Japanese name and sung in a way that recalled not Korea but a cultural ethos shaped in Japan that involves consuming "tears of longing". 14 


\section{"Imjin River" in Japan}

As mentioned above, "Imjin River" was initially brought to Japan in 1960 as a song in Ch'ongnyŏn schools. However, its eventual popularity and wide circulation in Japan was largely due to a popular Japanese underground band, the Folk Crusaders. Matsuyama Takeshi, a friend of Katō Kazuhiko, the band's lead singer, first came across the song when he visited Kyoto's Ch'ongnyŏn High School (Kyōto chōsen chūkōkyū gakkō) in 1961 as a student to arrange a football game between his school and theirs. After hearing it emanating from a music practice room, he acquired a transcription handwritten by his Korean friend's sister (Matsuyama 2002: 27-47; Dew 2016: 51) but forgot about it until a student folk song scene emerged in Kansai in the latter half of the 1960s. Hearing "Imjin River" again and thinking it was a Korean folksong, he introduced it to Katō, then at Kyoto University, and they arranged it for the Folk Crusaders. Matsuyama translated its first verse and added lyrics to the second and third verses. The Folk Crusaders recorded it in Japanese as the lead single for their self-produced and independently released first album (Dew 2016: 51). ${ }^{15}$

With the group's rising popularity, by 1968 the Japanese version, "Imjin River" (Imujingawa), had become well known to Japanese college students, especially those in the Kansai area (Mitsui 2013). That year Toshiba Records approached the band with an offer to produce and release a commercial album for them called Imujingawa. The release did not materialise as Toshiba withdrew from the project at the last moment due to the complications involved with licensing and the socio-political milieu between the two Koreas and Japan. Despite Matsuyama's naïve presumption that "Imjin River" was a Korean folksong, its composer and lyricist were still alive and the song was thus North Korean intellectual property. When Ch'ongnyŏn learned of Toshiba's production of Imujingawa, it accused the record label of neither acknowledging the North Korean sources nor seeking their permission and even changing the lyrics in translating it into Japanese (Dew 2016: 48). Ch'ongnyŏn thus demanded that the song only be recorded if the original North Korean lyrics were more faithfully translated and acknowledgement of the song's North Korean origins provided. The organisation also wanted Toshiba to apologise publicly to North Korea for not seeking its permission when they first planned to produce Imujingawa (Dew 2014: 139). Some also suspected that Toshiba decided to withdraw release because the Japanese government was wary about political complications with South Korea from disseminating a North Korean song locally. In fact, mindful of potential friction between Japan and South Korea, in 1970 the Japan Commercial Broadcasters' Association (Minpōren) banned "Imjin River" and the song was unable to be broadcast until 1987, when the system of blacklisting was abolished. Nonetheless, the song remained popular into the 2000s in Japan, where it has featured in films, live concerts, and television music programmes, performed by the Folk Crusaders and others like Kim Yŏnja, Zainichi Korean blues musician Arai Eiichi, and Miyako Harumi (Dew 2016: 48-51). 
In the Folk Crusaders' version of "Imjin River", the lyrics and music went through transformation from the original North Korean version. Mastuyama's main lyrical change was to replace the pro-communist lines in the second and third verses with the resentful lament asking "who divided my motherland in two", thus turning the song into a critique of the Cold War division of the peninsula without the people's consent. In the third verse, Matsuyama brought back the theme of affection for one's native place. While similar to the yearning for the South Korean homeland expressed in the first verse, the third differs in that there is no specific reference to where the home is located: "Far in the sky over the Imjin River/rainbows are rising/Imjin River, deliver my heart and love to my homeland". While in its Japanese pronunciation as "Imujin" the name does not sound Japanese, an average Japanese listener would not immediately think it's Korean, either. So, in this verse, Imjin River can be an imaginary river in an imaginary location. Moreover, this time the lyrics leave out the direction in which the river flows so that both Koreans and Japanese can more readily map their own homeland onto the lyrics, even if to some the Imjin River still suggests that the homeland is within Korea.

The Folk Crusaders also increased the tempo of the sedate melody sung in the North and emphasised the downbeats with strumming guitars supported by a bass line to evoke the folk/rock sound popular in the 1960s. Differently from the silky North Korean voice or the emotion and vibrato-laden enka performance, the Folk Crusaders' three male singers performed "Imjin River" in sweetly rendered unison with occasional harmonies, accompanying themselves on acoustic guitars and double bass. ${ }^{16}$

The Folk Crusaders' "Imjin River" was particularly appreciated by students influenced by contemporary American protest movements and social activism (Mitsui 2013), who came to know the song through the Folk Crusaders' performances (Dew 2016) and radio broadcasts of the version on their first album (Mitsui 2013: 85). ${ }^{17}$ The group's musical restyling, together with Matsuyama's new lyrics, shifted "Imjin River" from a North Korean song of the people to a student protest song, representing youth identity in the Kansai area and evoking sentiments that drove student peace and anti-US movements, which also led to criticism of how the Cold War affected people in Northeast Asia.

As musicologist Toru Mitsui states, a key motivation of musicians who participated in the 1960s underground folksong movement was desire to compose songs that commented on domestic and international events (Mitsui 2013: 95-96), and in this regard, "Imjin River" marks a period of Japanese youth protest. Indeed, the partition of Korea was not a completely external issue in the minds of progressive Japanese since it also divided Zainichi Koreans into two camps. While Koreans generally have been treated as second-class citizens in Japan, the marginalisation of those seemingly allied with North Korea has been more intense. Japan's lack of formal recognition for the North Korean government or North Korea as an autonomous and legitimate state also means that nationalist voices have often stereotyped them as a potential threat to Japan's security. 


\section{Sunhee Koo}

The racial conflict between (North) Koreans and Japanese is well depicted in the 2004 film Pacchigi! (Break Through!), directed by Lee Bong-ou [Yi Pongu]. The film is based on Matsuyama's 2002 memoir, Boy M's Imjin River (Shōnen $\mathrm{M}$ no Imujingawa), in which he reminisces about his encounter with the song and his work with the Folk Crusaders. The film's soundtrack features the Folk Crusaders' version of "Imjin River". In the film, Matsuyama's story is presented with focus on a romance between a Japanese boy based on himself and a Zainichi Korean girl (Dew 2016). The Imjin River in the context of Pacchigi! becomes the Kamo River, which runs through the centre of Kyoto, and the North/South Korea division evoked in the song becomes Japan's own wellentrenched racial divisions in the film, exemplified by the gulf between Koreans and Japanese. In the film, "Imjin River" is heard in at least two important scenes that enact, respectively, wishful inter-ethnic harmony and the reality of racial segregation in Japan.

If the Folk Crusaders' "Imjin River" was a sign of Japanese youth identity, particularly that of college students who spoke out against injustices they linked to the Cold War and American hegemonic power, its use in Pacchigi! comments on diasporic Koreans in Japan and the obstacles they have faced as ethnic, national, and state subjects. Just as the Imjin River can symbolise both division between the two Koreas and the legacy of Cold War or inter-racial conflicts in Japan, "Imjin River" can resonate with multiple identities because of its ability to evoke varied identities, including North Korean, pan-Korean, Japanese postwar generation/youth, and Zainichi Korean, all of whom may interpret experiences of war, separation, and social injustice in their own ways and as such relate to and be moved by the song.

\section{Conclusion: music, emotion, reconciliation}

Over the last two decades, the subject of emotion has garnered increasing attention in the social sciences, especially in terms of its public significance and the role it plays in constituting identity and community in the contexts of political violence and trauma. Political science scholars Emma Hutchison and Roland Bleiker state:

Emotions play a particularly central role in constructing a sense of identity and solidarity that can emerge despite - or, rather, as a direct response to the feelings of pain, solitude, and fragmentation that are engendered by the trauma ... a "culture of pain" (Morris, 1993) - can therefore become instrumental to the constitution of community and the sense of collective identity that emerges in the wake of trauma.

(Hutchison and Bleiker 2008: 390)

In investigating the relationship between emotions and identity, this study has focused on music and explored how its power to create emotional effect leads to and reinforces the construction of identity and community. "Imjin River" has 
gained layers of significance outside of North Korea as part of popular culture in Japan and South Korea; the emotions evoked by the song have not only allowed it to stand for various identities that Koreans and Japanese can relate to but also suggested how both Koreans and Japanese alike can potentially view each other as peoples affected by war, colonialism, and post-colonial dynamics.

Societies that have gone through conflict and violence - whether at the hands of internal or external forces - can be divided by the pain of the past and continuing injustices or by the emotions that accompany traumatic histories and memories. These emotions do not have to be first-hand and can extend to broader social relations (Hutchison and Bleiker 2008: 391).

In the case of Korea and Japan, "the pain of the past" is complex and ambivalent, especially for Koreans who hold vivid or mediated memories of collective pain under Japanese colonialism as well as the nation's partition. On the other hand, even though Matsuyama is not Korean and has not experienced the partitioning of his homeland, his version of "Imjin River" asks, "Who split my motherland in two? Who split my motherland in two?" In his memoir he tells how the Folk Crusaders' Katō Kazuhiko preceded performances of "Imjin River" with an invitation to the audience to think about what had happened to Korea: "Everyone please imagine. What if, somewhere in between Osaka and Tokyo, Japan was torn asunder?" (Matsuyama 2002: 7, 45; Dew 2016: 45). Although the majority of Japanese have no direct experience of either the partitioning of the Korean peninsula nor the racial bias that Zainichi face, the emotion that surrounds trauma and injustice can be transferred, "transcending the structures and boundaries within the wider social or communal sphere, and can influence perceptions of the world and of others" (Hutchison and Bleiker 2008: 391).

In this chapter, I have discussed the reconceptualisation of the North Korean song "Imjin River" in various contexts and interpreted feelings evidently evoked by the song as it went through multiple sonic transformations. Originally a North Korean song with an explicit pro-communist message, it was introduced to South Korean audiences in the milieu of liberal democracy. Although "Imjin River", as a pro-communist song sung in the unique vocal style of the North, can represent a North Korean identity, it also can become a sign of South Korea or pan-Koreanness when repackaged with different visual and sonic markers: in the South, the song has been deployed to signify ethnic identity by evoking the sense of loss resulting from partition, a sentiment shared between the two Koreas. In Japan, "Imjin River" also has shifted from a North Korean song sung in Ch'ongnyŏn schools, to a popular tune sung by the Folk Crusaders, and then an enka piece, a genre viewed as nostalgic Japanese national music. In Japan, the song symbolises the national identity of Koreans committed to North Korea and simultaneously is re-stylised as enka, the appreciation of which is linked to emotional experiences offered to fans in Japan. In its enka adaptation, the song's political message is neutralised with lyrics frequently encountered in enka that evoke sentiments of separation and longing similar to those Koreans experienced with partition. The musicians and audience for the Folk Crusaders" "Imjin River" 


\section{Sunhee Koo}

were college youths attuned to domestic and international affairs. In this version, designed to appeal to youth, both music and text were noticeably modified from the original, and the questioning of partition implies criticism of the Cold War and foreign power exercised over a country without the consensus of its people. Desire for freedom and empathy for the Cold War's victims creates pain in listeners' minds. This version reappears in the soundtrack for the 2004 film Pacchigi!, with the song's evocation of the pain of Korean division mapped onto Japan's inter-racial dissonance. As the song is adapted into different spectrums of music across Korea and Japan, the music and the lyrics change, yet the emotion and sentiment created by "Imjin River" remains similar, whether coming from direct Korean experience or being vicariously imagined by Japanese audiences.

What has enabled "Imjin River" to remain popular and in demand beyond cultural and social borders? I propose in conclusion that the song's power lies in the process of interpretation, where the song carries a range of meanings while evoking emotion linked to the pain of separation and longing for something lost: homeland, family, friends, youth, or even social power or justice. Whether in the form of a pro-communist song, nostalgic pop, or 1960s protest, "Imjin River" has found relevance over 60 years in Northeast Asia, where the experience of Korean partition and ensuing power imbalance remains unresolved and continues to generate strong sentiment.

\section{Notes}

1 The romanisation of the North Korean orthography would give "Rimjin'gang". This work was supported by the University of Auckland's Faculty of Arts Research Development Fund and the Core University Program for Korean Studies through the Ministry of Education of the Republic of the Korea and Korean Studies Promotion Service of the Academy of Korean Studies (AKS-2017-OLU-2250001).

2 Despite the generally accepted idea that "Imjin River" is a favourite North Korean song (see "A Song to Imjin River", mouonekorea.wordpress.com/2012/06/ 07/a-song-to-imjin-river/and Hankyoreh Community, c.hani.co.kr/hantoma/3138233), Yi Ch'ollchju of Internet newspaper Minplus speculates that the song may have been more popular in Japan, especially as it came out in the North when the people were caught up in the Ch'ollima (Thousand-Mile Horse) movement for rapid economic development. As such, he believes that they had little room to enjoy music, be sentimental, long for home, or feel sympathy for the South, which was then falling behind the North economically. In Japan, the majority of Koreans had come from Korea's southwestern provinces during the colonial period, and for them, the song's evocation of hometown in the south resonated strongly. For Yi's interpretation, see "Ko Chonghwan, the Composer of 'Imjin River'”, www.minplus.or.kr/news/articleView.html? idxno $=187$.

3 For a brief introduction to the song, see "A Song to Imjin River", mouone korea.wordpress.com/2012/06/07/a-song-to-imjin-river/.

4 Cho Ch'ŏngmi's version of "Imjin River": www.youtube.com/watch? $v=m$ tk SXWnJiMc.

5 For more about Cho see "Cho Ch'ŏngmi, the Prima Donna of Japanese Koreans", www.minplus.or.kr/news/articleView.html?idxno=991.

6 See "Cho Ch'ŏngmi, the Prima Donna of Japanese Koreans". 
7 See "Cho Ch'ŏngmi, the Prima Donna of Japanese Koreans", and "Wishing for the Culmination of Self-Reliance Arts", naenara.com.kp/ko/society/?literary+33+1762.

8 See "Ko Chonghwan, Composer of " 'Imjin River." "

9 T'ǔrotŭ in South Korea is also referred to as chŏnt'ong kayo (traditional popular song), projecting an origin with links to the past.

10 Both $t$ 'urrotŭ and enka evolved from early twentieth-century popular song. As a result, in post-colonial Korea $t^{\prime}$ urot $\breve{u}$ was criticised as a legacy of the Japanese Occupation. Regardless of Japanese or indigenous origins, the genre continues to be produced and consumed in South Korea today.

11 The official website for this programme can be found at smart.kbs.co.kr/tv/enter/ gayo/.

12 For Kim Yŏnja's “Imjin River” on KBS's Kayo mudae broadcast on 21 September 2015, see: www.youtube.com/watch?v=kUGIymf2x3k.

13 Kim's Japanese version of "Imjin River": www.youtube.com/watch?v=GOFFjpyVmvI.

14 The phrase "tears of longing" is borrowed from the title of Christine Yano's book (2002).

15 As an independent album, only a small number of copies were made.

16 Folk Crusaders" version of "Imjin River": www.youtube.com/watch?v=M6I7by V5Zu8.

17 According to Tōru Mitsui, in 1967, “'Imjin River’ was regularly played on local radio: Kinki Broadcasting (Kinki Hōsō) played it for two months on their show, Song of the Week" (Mitsui 2013: 85).

\section{References}

Dew, Oliver. 2016. Zainichi Cinema: Korean-in-Japan film culture. London: Palgrave.

Dew, Oliver. 2014. 'Pacchigi, the Imjin River Incident and '1968': Transmedia history telling”. Journal of Japanese and Korean Cinema, 6 (2): 134-151.

Howard, Keith. 2006. "The People Defeated will Never be United: Pop music and ideology in North Korea", in Korean Pop Music: Riding the wave, edited by Keith Howard. Folkestone, UK: Global Oriental: 154-167.

Hutchison, Emma and Roland Bleiker. 2008. "Emotional Reconciliation: Reconstituting identity and community after trauma". European Journal of Social Theory, 11 (3): 385-403.

Matsuyama, Takeshi. 2002. Shōnen M no imujin-gawa [The Imjin River of Boy M]. Tokyo: Kirakusha.

Mitsui, Tōru. 2013. "Music and Protest in Japan: The rise of underground folk song in '1968',', in Music and Protest in 1968, edited by Beate Kutschke and Barley Norton. London: Cambridge University Press: 81-96.

Peirce, Charles Sanders. 1955. Philosophical Writings of Peirce. Edited by Justus Buchler. New York: Dover.

Reyes, Adelaida. 2014. "Identity Construction in the Context of Migration". Il Saggiatore Musicale, 21 (1): 105-121.

Shamoon, Deborah. 2014. "Recreating Traditional Music in Postwar Japan: A prehistory of enka". Japan Forum, 26 (1): 113-138.

Turino, Thomas. 1999. "Signs of Imagination, Identity, and Experience: A Peircian semiotic theory for music". Ethnomusicology, 43 (2): 221-255.

Turino, Thomas. 2008. Music as Social Life: The politics of participation. Chicago and London: University of Chicago Press.

Yano, Christine R. 2002. Tears of Longing: Nostalgia and the nation in Japanese popular song. Cambridge, MA and London: Harvard University Press. 


\section{Sunhee Koo}

\section{Music links}

Cho Ch'ŏngmi's version produced in North Korea: www.youtube.com/watch?v= uz6mZ-A_xTg.

Kim Yŏnja's version: (in Japan) www.youtube.com/watch?v=jQiShG38YJE and www. youtube.com/watch? $\mathrm{v}=$ GOFFjpyVmvI; (in South Korea) www.youtube.com/watch? $v=$ kUGIymf2x3k.

Folk Crusaders' version: (1968) www.youtube.com/watch?v=1-eJDL3zLCQ, (2000) www.youtube.com/watch?v=X7vU85smoMA (2004, in the movie, Pacchigi!) www. youtube.com/watch?v=k6t516sg-kk www.youtube.com/watch?v=89EkDmzW5J8. 


\title{
9 Industrial miracle or Hell Island? \\ Gunkanjima, television, and nationalism in South Korea and Japan
}

\author{
Yoojin Choi
}

\section{Introduction}

Gunkanjima is a 16-acre island located roughly 15 kilometres off the coast of Nagasaki city. Formerly operated as a coal mine by the Mitsubishi Heavy Industries Group, the island was known for its modern concrete apartment blocks and once had one of the highest population densities in the world. Following Japan's transition from coal to oil-derived energy, Gunkanjima was abandoned in 1974 but has recently attracted worldwide attention as a haikyo (ruins) site, that is, an abandoned area that has become a tourist attraction of "urban exploration and artistic documentation" (Dixon et al. 2016: 174). Since July 2015, Gunkanjima has been included on the UNESCO World Heritage List as one of 23 locations comprising the "Sites of Japan's Meiji Industrial Revolution: Iron and Steel, Shipbuilding and Coal Mining". Gunkanjima's listing, however, was strongly opposed by the Korean government because of its history as a site of Korean forced labour during the Second World War. The island immediately became a contested historical battleground between Korea and Japan, joining such controversies as the debate over revisionism in Japanese textbooks, Yasukuni Shrine visits, and the issue of "comfort women". Ultimately, Gunkanjima has become bound up in two distinct national narratives. For Japan, it functions as a proud witness to modern Japanese industrialisation, whereas, for Korea, it acts as a painful reminder of Japanese war imperialism, colonisation, and the dark history of forced labour. As a result, one finds dichotomous portrayals of Gunkanjima as an "industrial miracle" and as a "Hell Island".

This chapter seeks to explore the increasing attention paid to Gunkanjima beyond the strictly political realm, as evidenced by the recent proliferation of popular culture and media representations of the island. Leading up to and following the UNESCO bid, Gunkanjima has become much more visible in both the Korean and Japanese television spheres, with each nation pushing its own views of the island. This chapter draws on entertainment television shows as a key window into reading Gunkanjima and the significance of its contemporary images in the Japanese-Korean wartime legacy. In doing so, I hope to show how the contested memories of Gunkanjima between Korea and Japan have emerged as an important new, transnational site in the complex web of memory, popular culture, and history between the two nations. 
This project views Gunkanjima as operating within the framework of memory politics and focuses on the potential for television to generate, influence, and serve as a vehicle for public memory. Television, as framed by Edgerton (2001: 4), is "a popular art form", "an evolving technology", "a business and industry", and most importantly, "a historian" that helps shape mass understanding of the past. Chiho Sawada (2016: 222) describes television as an easily accessible and entertaining site of memory that requires less time, effort, and expense for consumption than enrolling in a university course, travelling to a historic location, or visiting a national museum. Steven Anderson (2001: 20) further argues that television facilitates a society's ongoing negotiation with its past by portraying aspects of collective memory that may not be factually accurate but are most relevant and engaging to audiences in the present. Thus, television sustains active engagement in not only the circulation and consumption of the past, but also the construction of its representations.

Recently, some scholars (e.g. Andrejevic 2007) have embraced digital platforms as "virtual spaces" through which information and memory artefacts are produced, disseminated and consumed; others (e.g. Hardenbergh 2010) have gone so far as to proclaim the "death" of television with the arrival of online media. Nonetheless, the place of television in contemporary historiography has remained crucial even amidst this accelerating global shift towards digital platforms, and there has been a reconfiguration of television characterised by "technological convergence, multiple channels, and unlimited broadcasting and interactivity", which have generated different modes for viewers to receive, process, and remember the past (Lozano 2013: 142).

These two key frameworks - television and memory - thus serve as the basis for this chapter's exploration of Gunkanjima as a focal point of memory work within Japan and Korea and the "memory problem" that exists between them. In what follows, I introduce Gunkanjima in the context of the shifting landscape of contemporary Korean-Japanese war memory and then examine how Gunkanjima is presented on Japanese and Korean television respectively before moving on to discuss the antagonistic discourses of Gunkanjima between the two nations and the wider significance of these discourses. I argue that Japan and Korea display similar strategies of representation and style in their characterisation of Gunkanjima, with similar ambitions of exhibiting a nation, bound by ethnicity, culture, and national identity, in ways that urge their citizens to view the island exclusively from their own national perspectives.

\section{Gunkanjima as a UNESCO heritage site: contested war memories}

In May 2015, UNESCO reported that "Sites of Japan's Meiji Industrial Revolution: Iron and Steel, Shipbuilding and Coal Mining" had been nominated for the World Heritage list. Comprising 23 locations, mainly in the Kyūshū and Yamaguchi regions, these sites, including Gunkanjima, collectively represent "the first successful transfer of industrialisation from the West to a non-Western 
nation", wherein Japan rapidly industrialised over "a short space of just over fifty years between the 1850s and 1910" and are considered "an outstanding reflection of the way Japan moved from a clan based society to a major industrial society ... profoundly influenc[ing] the wider development of East Asia" (UNESCO 2015).

South Korean representatives immediately objected to the UNESCO nomination, noting the use of Korean forced labour at seven of these sites, including Gunkanjima. Records reveal that 1,299 Koreans died in Gunkanjima between 1925 and 1945 due to its dangerous and harsh working and living conditions (Association to Protect the Human Rights of Resident Koreans in Nagasaki 2016). The Korean government harshly criticised Japan's nomination as an attempt to rewrite its war history and demanded that Japan recognise the use of forced labour at these sites. The Japanese government rejected these calls as "political claims" (Takazane 2015). After much negotiation, the two governments reached a compromise, agreeing on a wording relating to the use of Korean forced labour. Japan issued a statement that it would take measures to "allow an understanding that there were a large number of Koreans and others who were brought against their will and forced to work under harsh conditions in the 1940s at some of the sites, and that, during World War II, the Government of Japan also implemented its policy of requisition" (Ministry of Foreign Affairs of Japan 2015). The Korean delegation agreed and noted that Korea "decided to join the Committee's consensus decision on this matter" with "full confidence in the authority of the Committee and trust[ing] that the Government of Japan will implement in good faith the measures it has announced" (World Heritage Committee 2015).

Unfortunately, Gunkanjima quickly became a new contested site of memory between Japan and Korea, as, the day after the nomination, Minister for Foreign Affairs of Japan Kishida Fumio announced that the statement's use of the phrase "forced to work" corresponded to hatarakasareta (were made to work) and not the more contentious kyōsei rōdo (forced labour), which was employed in the 1930 Forced Labour Convention and highlights Japanese war aggression (Yoshida 2015). As Palmer (2017) argues, the difference indicates that the Japanese government, in practice, does not acknowledge the use of illegal forced labour. Kishida further noted that "the years that are relevant to the World Heritage sites are the 1850 s to 1910 " and, therefore, are "different from the time frame, historical assessment, and background context of forced labour" (Takazane 2015). The Korean government expressed strong criticism of Kishida and focuses instead on the role of forced labour in Japan's industrialisation and empire-building. The Korean view holds that Gunkanjima and six other "Sites of Meiji's Industrial Revolution" should address the dark history of Japanese war aggression, colonisation, injustice and forced labour. As with Japan's textbook controversy, Yasukuni Shrine visits, and the "comfort women" issue, the debate concerning Gunkanjima has made the island part of a transnational memory problem. The successful UNESCO registration of Gunknjima juxtaposed narratives between Korea and Japan: for Japan, Gunkanjima symbolises the rapid 
industrialisation between the 1850s and 1910 that contributed to Japan's rise as a world-ranking industrial nation in the early twentieth century; for Koreans, however, Gunkanjima marks a site of suffering and victimisation through forced labour between 1939 and 1945 that calls for justice. It is in this context that television images and stories of Gunkanjima have been produced, disseminated, and consumed.

\section{An industrial miracle: representations of Gunkanjima in Japanese television}

In this section, which examines images of Gunkanjima disseminated by a popular Japanese TV show, Quiz! Sore Maji?! Nippon (Quiz! Is that for real?! Japan; hereafter, Sore Maji), I highlight the centrality of Japan's self-perceived exceptionalism in shaping the memory politics of Gunkanjima in the television landscape. Using Sore Maji as an anchoring text, I show how Gunkanjima is depicted as a historically important site that accomplished several "firsts" for Japan and the world, as well as enjoying an affluent lifestyle during the post-war period. I then explore how Gunkanjima's Japanese coal miners are characterised by their sacrificial spirit and their contribution to Japanese modernisation and argue that the show selectively and repeatedly "remembers" Gunkanjima only in positive terms, embracing a vision of the island as "an industrial miracle" while "forgetting" the existence of Korean forced labour. I further note how this strategic act of forgetting, rooted in the Japanese government's continued resistance to acknowledging and affirming wartime aggression, is symptomatic of contemporary East Asian memory problems.

Sore Maji is an entertainment quiz programme that aired weekly on Fuji Television on Sundays from July 2014 to August 2015. The narratives presented by the show are often positive and celebratory, showcasing Japan's proud cultural and aesthetic achievements or its remarkable natural landscapes through such themes as "Representative foods of each prefecture in Japan", "Location of the G7 summit in Japan", and "Top Japanese views you must see before you die". On 17 May 2015, the show featured an episode on Gunkanjima and two other sites of the Meiji Industrial Revolution under the title, "Attention to the World Heritage Site Inscription!" Focusing on the island for more than half the show, Sore Maji shows how Gunkanjima is remembered in Japan as a classic, triumphant example of Meiji industrialisation and post-war economic growth.

The show features travels throughout Japan to rediscover "fascinating" aspects of the nation by four Japanese tarento (media personalities): Hayashi Osamu, a yobikō (prep classes for Japan's university entrance examinations) lecturer; ${ }^{1}$ Taka and Toshi, a popular comedy duo; and Uchida Reina, a female announcer with Fuji Television Network. Dubbed the "Japanese master", Hayashi performs the role of school teacher and educates the other presenters about the relevant history or cultural background of the places they visit. Always in a suit, Hayashi leads the show in a rational but charismatic and calm manner 
and dominates its voiceover narration. Taka and Toshi play the role of students, asking questions, chiming in with jokes and showing amazement at the "surprising" truths about Japan taught to them. Uchida rarely participates in group conversations and is primarily responsible for dramatic reactions - her high-pitched exclamatory remarks often feature as on-screen graphics to emphasise what the other presenters have said. The teacher-student dynamic between Hayashi and Taka and Toshi as proxies for the audience therefore becomes the primary means of conveying information and progressing discussion; Uchida provides emotional commentary.

Sore Maji positions Gunkanjima as a crucial site of industrial heritage within the narrative of Japanese exceptionalism. The episode begins by introducing Japan's first concrete apartment building, built in Gunkanjima in 1916. As soon as Hayashi spots the building, he shifts into teacher mode, presenting a leading question: "What object built on Gunkanjima in 1916 was a 'first' in Japan?" Taka and Toshi, who appear to have no knowledge of the island, look puzzled and raise their hands to ask for hints while Uchida makes "ehh?" sounds to signal curiosity. Hayashi drops a final hint that the "object" is located right in front of them. Toshi now has a flash of realisation and correctly answers, "the first concrete apartment building". Hayashi then explains that the apartment, successfully built in 1916, when industrial architecture was still in an experimental stage, symbolises Japanese proactive industrial progress to protect against typhoons and high tides. Hayashi further links the development of Japan's first apartment building to a wider urban industrialisation that eventually accommodated about 1,400 people per hectare - "the world's highest population density". Here, the "Japanese Master" emphasises "the world" in an excited tone with broad hand gestures, suggesting pride in Japan's majestic achievement.

The celebratory narrative of Gunkanjima finds another focus in Sore Maji where the post-war lifestyle of the Japanese is depicted as affluent. After Hayashi's commentary on the island's population density, Taka notes, "Living in a small island with so many people must have been very difficult with limited food, electricity, and water". Hayashi responds that this is a common misconception of life in Gunkanjima during the Showa era. ${ }^{2}$ He explains that the locals had a wealthy, urbanised lifestyle, with all the amenities one would expect from a much larger city. As part of an in-show quiz, the panellists discover that the island housed not only schools, a barber shop, a Shinto shrine, a hospital, a police station, and a post office, but also entertainment facilities, including a department store, a pachinko parlour, a cinema, and a swimming pool. Elation appears on Hayashi's face as the others' jaws drop in astonishment, and their perception of Gunkanjima shifts from today's industrial ruins to that of a vibrant cityscape that once ranked among the most luxurious living spaces in the country. The representation of Gunkanjima's lavish lifestyle signifies advancing modernity for a rapidly industrialising Japan. ${ }^{3}$

Sore Maji allots considerable attention to the Japanese miners, their strength, and their sacrifice. The context of this narrative is framed when the presenters encounter the "Stairs of Life" - steps at the mine entrance that descended down 
a path to 600 metres below sea level. Accompanied by black and white photos of miners in 1959, Hayashi comments that the sooty stains on the stairs do not result from decay, but the traces of the thousands of miners who commuted, covered in coal, to the mine via these stairs. Hayashi enthusiastically describes the stairs as a "historical witness" to the hard work and determination of the Japanese miners who risked their lives daily in a dangerous environment. The show strongly communicates the message that Japan's industrialisation required great sacrifice and that contemporary Japanese owe a debt of respect and gratitude towards the miners' dark, suffering past. The glorification of Gunkanjima's miners continues as Toshi refers to Antonio Inoki, a legendary Japanese wrestler nicknamed "Burning Fighting Spirit": "The stairs should be called the Inoki no Kaidan ["Stairs of Inoki", a pun on inochi no kaidan, "Stairs of Life" in Japanese) because the miners had a burning, fighting spirit". Although intended comedically, Toshi's analogy is worth noting as he associates the figure of Inoki with the Japanese miners as symbols of masculinity, strength and tenacity, and more importantly, the "hard work" that they have contributed to themselves, their community, and their nation.

Hayashi builds on this idea by stating, "I think the Japanese people back in those days had a lot more energy than now". To Hayashi, Japanese energy "back in those days" is part and parcel of Japan's rapid industrialisation and growth, both during the Meiji era and in the post-war economic miracle that resulted in Gunkanjima's affluence in the later period. He attempts to awaken contemporary Japanese to the nation's glorious past when it led the world in heavy industry and the speed of its modernisation. While Sore Maji acknowledges the darker aspects of history in the form of the miners' harsh conditions and sacrifice, it follows the trend of earlier historical controversies, such as textbook revisionism and the Yasukuni shrine visits, of using precisely those aspects of the past to foster a sense of national pride.

Although Sore Maji remembers Gunkanjima as not only a repository of "firsts" for Japan and the world, but for the lavish lifestyle of its inhabitants in the post-war era, and the sacrificial spirit of its Japanese miners, the show entirely fails to recognise Gunkanjima as a site of Korean forced labour. In the narrative of Sore Maji, Japanese miners are the central figures of Gunkanjima's industrial success who willingly sacrificed themselves for their families, community, and nation. Although the show recalls their hard lives, no Koreans appear; Gunkanjima's forced labourers are thus doubly "forgotten" in this Japanese memory work.

The island's conspicuous presence as a prime image of "an industrial miracle", rather than a site of Korean forced labour, reveals Sore Maji's desire to remember an untarnished, glorified version of the past. As Lowenthal argues (1985: 206), "memory transforms the experienced past into what we later think it should have been, eliminating undesired scenes and making favoured ones suitable". Here, Sore Maji envisions Gunkanjima as it wants viewers to know it - as a coal mining site that played a vital role in Japan's industrial revolution and as a futuristic city with a wealth of leisure and everyday amenities. Japanese 
imperial aggression and Korean forced labourers are therefore absent, for they render difficult a consistent positive narrative of the island as a proud example of Meiji industrialisation and post-war peace and prosperity. The forgetting of Koreans suggests a desire to erase, or at least sidestep, the image of Japanese imperial aggression while simultaneously glorifying Japan's industrial modernisation. Such forgetting therefore becomes a political act, for it leaves little space for dissent and contestation and its myopic attitude limits possibility for the public to engage in a dialogue over historical consciousness. Within this context, Sore Maji's representations of Gunkanjima continue Japan's desire to forget acts of imperial aggression, to revive the glorious past and to stimulate pride in the steel, iron, shipbuilding, and coalmining industries that have affirmed modern Japanese history.

\section{Hell Island: representations of Gunkanjima in Korean television}

This section explores how Gunkanjima is actively "remembered" in Korean television as a site of "dark heritage" that highlights the sufferings of Korean forced labourers during the colonial era (1910-1945) at the hands of the Japanese. Han (2016) defines the term "dark heritage" as "built structures and materials" that are "dark" and "hardly attractive", a metaphorical "heritage of shame" that directly relates to "the aggressive wars of Japan in terms of perpetration, suffering, collaboration or resistance" (290). Here, through an episode of the Korean show Infinite Challenge, I show how the memory politics of Gunkanjima in Korean television are firmly grounded in the dichotomy of victim/victimiser and discussed in relation to themes of trauma, exploitation, and victimhood.

Infinite Challenge (Muhan tojŏn) is a popular Korean entertainment programme in which six comedians aim to complete absurd or seemingly impossible challenges over the course of a day or even as much as a couple of months, with the purpose of redefining "the impossible". In addition to entertaining, the show aims to inspire ordinary Koreans with its motto, "If people like us can do it, you can do it too!" The cast includes some of the country's most popular comedians, such as Yu Jaesŏk, Ha Donghun, more commonly known as Haha, Pak Myŏngsu, Cho Seho, Yang Sehyŏng, and Chŏng Chunha, and the show, airing weekly on Saturday evenings on Munwha Broadcasting Company (MBC), receives consistently high ratings and has frequently topped Korean Gallup's Top 10 Most Loved Television Shows list since 2005. While the challenges vary, they often evoke the changing social geography of Korea and its relation to the rest of the world.

From 15 August to 12 September 2015, the show featured a four-episode challenge commemorating the seventieth anniversary of Korea's Independence on 15 August 1945. Over four weeks, the presenters travelled to different countries to deliver Korean food to Korean families living abroad, with the aim of bringing "all Koreans together" through food, which regularly symbolises nostalgia, the tastes of home, and a mother's affection. 
In the final episode, Haha and Professor Sŏ Kyŏngdŏk of Sungshin Women's University are seen arriving on Gunkanjima, bringing a meal dedicated to the Korean forced labourers who worked and died on the island for little or no income and suffered from inhuman conditions as miners. ${ }^{4}$ The episode elaborates on their suffering, and, through juxtaposition with Japanese experiences on Gunkanjima, develops a narrative of Japanese victimisers and Korean victims.

The episode begins with a sand art performance that tells the story of "two separate worlds" in Gunkanjima, presenting a dichotomous relationship between Korean victims and Japanese victimisers. A voiceover narration intones:

On the ground level, there was the luxurious lifestyle of the Japanese. At the lowest level of the basement were Korean forced labourers. On the playground were Japanese kids. Below the 1000-metre tunnels underneath the seabed were fourteen- and fifteen-year-old Korean boys. The working environment was brutal - 45 degrees, with continuous starvation and pain. Confined by sea, it was impossible to escape Hashima Island, thus called Prison Island or Hell Island.

Despite inhabiting the same landscape, the contrasting lives of Koreans and Japanese in Gunkanjima during the colonial period are put in sharp relief. The sand art identifies Koreans as victims, forced to work underground, appearing vulnerable, exploited and suffering, while the Japanese are constructed as happy, affluent, and enjoying a pleasant lifestyle. With this opening, Infinite Challenge lays the foundations for a discourse of Korean victimhood in opposition to the Japanese Other in its memory construction of Gunkanjima.

Having established victim-victimiser categories, the show proceeds to a discussion of Gunkanjima as a contemporary issue. Like Sore Maji, Infinite Challenge calls upon a professor to offer intellectual authority in explaining the situation to one of the comedian presenters. So explains to Haha that Japan registered Gunkanjima as a UNESCO World Heritage Site without mentioning the history of the island as a site of forced labour between 1910 and 1945. He criticises the revisionist attempt of the current Japanese government bitterly, saying, "These are Japan's antics. The years for the World Heritage Sites submitted by the Japanese committee were 1850 to 1910 . They erased colonial history, using only what came before". Haha plays his part as a stand-in for the viewer; he is assumed to have no pre-existing knowledge of the island and seems livid.

The show then introduces two surviving Korean forced labourers, Ch'oe Changsŏp and Kim Hyŏngsŏk, to recall their traumatic experience of Gunkanjima and shifts its focus to their individualised narratives to invoke personal tragedy and trauma. In 1943, at age 16, Ch'oe was dragged to the island with no explanation. He only found out upon arrival that Gunkanjima was a coal mine and was put into the underground lodging of a nine-storey building. Kim was conscripted at age 20 in the same year. He soon went blind from the need to constantly swipe his eyes with a towel covered in coal dust. Memories of fellow miners screaming "I'm starving" or "my leg cramps are killing me" all night 
remains a significant trauma for him to this day. When asked about the food they missed most during their years of forced labour, Kim replied, "I would have died with no regrets if I had gotten to eat a bowl of rice and meat soup". It is hard to resist emotional involvement upon hearing these traumatic memories on television, accentuated by sad, melodramatic music. The stories and images of Ch'oe and Kim arouse intense poignant feelings because they are real people who recount real experiences on Gunkanjima directly to the viewer. The authentic quality of personal memories adds weight to the discourse of Korean miners as victims.

The Infinite Challenge episode then further juxtaposes the "separate worlds" of Koreans and Japanese on Gunkanjima to reinforce the dichotomy of victim and victimiser. While Haha and Sŏ participate in a guided tour organised by the local Nagasaki government, viewers observe Japanese tour guides raising a black and white photograph of optimistic-looking Japanese workers in full mining gear. This image is contrasted with a photo of Korean miners who look exploited, exhausted, and injured. Ch'oe testifies that Korean miners were only given a pair of white underpants with little safety equipment and thus exposed to far greater danger. A similar contrast is made between a photo presented on the tour of cheerful Japanese residents at a modern restaurant, and one provided by the show of malnourished, cadaverous Korean labourers standing in a line looking nervous and stiff. A voiceover from Kim describes the trauma of starvation on the island for Koreans who were only given a meagre ration of leftover soybeans used to make oil, which never quelled their hunger even if they ate their breakfast and lunch together: "The Japanese did not provide rice, not even brown rice", he says.

The discourse of "two separate worlds" continues even to the grave. Haha and Sŏ travel to a neighbouring island, Takashima, to seek a monument titled "Tomb of the Thousand", which purports to contain the ashes of Korean labourers who died in accidents or during failed escapes from Gunkanjima. After three hours of searching, the two finally find the monument, lying neglected on an overgrown path in dense forest. So tells Haha that the Japanese had burned all official documents recording the causes of death for Koreans, thus making it impossible to identify the deceased. The monument is situated not far from the public cemetery for residents of Takashima. Neatly trimmed, the Japanese cemetery is well cared for, with frequent visitors as evidenced by fresh flowers. Again, a contrast between Korean labourers and Japanese residents, which remains even after death, contributes to the discourse of "two separate worlds" built up throughout the episode.

Within the above context, Infinite Challenge spreads a powerful message about Gunkanjima's status as a site of memory for contemporary Korea. The presentation of a meal to Gunkanjima's forced labourers, following the presentation of other meals to Koreans living abroad, emphasises the continued suffering of the miners and Gunkanjima's ongoing resonance. The show further dives into the landscape of the contemporary memory war when Sor heavily criticises the exclusion of Korean forced labour in the UNESCO narrative put forward by the 
Japanese government. In this way, Gunkanjima becomes not merely a site of historical suffering but a contemporary political issue within the East Asian memory problem. Infinite Challenge clearly sustains a high level of resentment towards the Japanese for their treatment of Koreans during the colonial period as well as their misrepresentation of history in the present.

The memory formation of Gunkanjima as both a historical and present site of suffering relies on and reinforces understandings of the Japanese Other. According to Lim (2010), the sustained Othering of the Japanese is required in South Korea's postcolonial national identity, as Korean suffering can only be brought into being by comparison with the Japanese Other; "Victims without perpetrators are unthinkable", she argues (Lim 2010: 1). It is thus worth noting that Infinite Challenge uses the juxtaposition of "two separate worlds" as a narrative strategy to convince viewers that the Japanese state is not the sole agent responsible for the traumatic memories of Korean forced labourers. Ordinary Japanese residents of Gunkanjima come to be represented as complicit and responsible. A case can readily be made for condemning Mitsubishi and Japan's military elite for the forced mobilisation of Koreans to Gunkanjima. Ordinary Japanese residents of Gunkanjima, on the other hand, may not as individuals have victimised Korean labourers or be responsible for their traumatic memories. While they may have lived in "two separate worlds", blanket condemnation for collective responsibility becomes more complicated. Nevertheless, such Korean vilification of Japanese colonialism shifts the anger, outrage, and hatred from specific perpetrators or the military government to the Japanese people as a whole, resulting in a dichotomy of Japanese as victimisers and Koreans as victims. In such a discourse, it becomes immaterial if the photos of happy Japanese and suffering Koreans are contemporaneous. Ordinary residents of Gunkanjima become guilty of persecuting Korean miners, simply by virtue of being Japanese.

By positioning itself against Japan, the variety show emphasises Korean victimhood. In this way, the collective memory of Gunkanjima as a site of suffering develops into an ethnocentric narrative of Us (virtuous Koreans) and Them (evil Japanese), which, in turn, offers a useful window into postcolonial Korean national identity and collective memory as a whole. However, just as Sore Maji is based in Japanese exceptionalism, the cultural memory of Gunkanjima in Infinite Challenge can be seen as reflecting a monolithic and ethnocentric Korean perspective on the colonial past.

\section{Conclusion}

This chapter has examined Gunkanjima, its place in the East Asian memory problem, and the public memories constructed around it through Japanese and Korean television. In Japan, Gunkanjima is presented through complementary narratives of the nation's glorious past: the Meiji industrialisation between the 1850s and 1910, and the post-war Showa period. The popular Japanese entertainment show Quiz! Sore Maji?! Nippon develops a narrative of Gunkanjima as an excellent example of the rapid industrialisation that contributed to defining 
modern Japan. The show also articulates Gunkanjima as a site of post-war affluence in a way that praises Meiji Industrial Revolution Sites and encourages appreciation for their role in contributing to this definition. Sore Maji further attempts to make Gunkanjima a uniquely Japanese heritage site, by suppressing or avoiding its past of colonialism, imperialism and wartime aggression, including Korean forced labour, in line with a recent surge of historical revisionism and neo-nationalism.

In Korea, the televised image of Gunkanjima is predominantly built through affective visuals and stories of forced labourers. The popular entertainment show Infinite Challenge depicts compatriots as vulnerable, exploited, and traumatised victims forced to work in extremely harsh, dangerous conditions under the surveillance of the Japanese. Through the personal testimony of two surviving miners, as well as photographic evidence, the show repeatedly asserts the dichotomy of Korean victims and Japanese perpetrators as a way to "remember" Gunkanjima as a "dark heritage" site. While the show commemorated the seventieth anniversary of Korea's independence, it demonstrates that traumatic memories of forced labour are still very much alive in relation to the contemporary Gunkanjima debate and Korea's wider nationalism based on feelings of victimhood.

Both Sore Maji and Infinite Challenge reinforce their own nationalisms, and there is a striking structural similarity in the treatment of Gunkanjima as a symbol of the Japanese nation, albeit through vastly different lenses. Sore Maji promotes Gunkanjima as an image of national pride for its rapid industrialisation during the Meiji period, its affluent post-war lifestyle and the Japanese miners' contribution to modernisation. Infinite Challenge similarly prefers generalisation over nuance and ignores that the island was owned by Mitsubishi, a private corporation, that forced labour was carried out by the military, and that forced labour occurred only during a limited period. Detailed provision of context about forced labour, war, and colonialism not only becomes unnecessary, but actively avoided. Diverse stories and images of Koreans and Japanese working and living on Gunkanjima disrupt the contrasting ethnocentric narrative of "two separate worlds".

This chapter has illustrated how each nation's identity persists and is consolidated through participation in and (re)production of unresolved controversies between the two. Although each Gunkanjima narrative opposes the other, both convey similar strategies of style and nationalist representations. Indeed, antagonism may be rooted in the similarities in approach. Both Korean and Japanese popular culture deliver firmly nation-based narratives of Gunkanjima, focusing on their specific collective memory, with no regard for the Other. As Kal (2008) concludes in his comparative study on the Yūshūkan and the War Memorial of Korea, the two nations" "selective forgetting and remembering of the past" build solidarity in the notion of "a patriotic and ever glorious national community". Thus, their nationalistic discourses are interconnected and engage with each other in both content and form. 


\section{Notes}

1 Hayashi is well known for his motivational guides and the famous catchphrase, "When are you going to do it? Now, of course!"

2 The Showa era (1926-89) includes the war years, but Hayashi here goes on to focus on the post-war Showa years in the 1950s-1960s.

3 The industrial heritage tourism that has evolved around Gunkanjima today further promotes the island as a site of post-war affluence. The local tour company Gunkanjima Concierge, for example, employs former residents as tour guides to depict the flourishing, auspicious lifestyle of the people living in Gunkanjima who prospered throughout the Showa period. Gunkanjima Digital Museum, established in September 2015, uses cutting-edge digital technology to exhibit a collection of archival images and personal stories that portrays nostalgic images of everyday life, such as children playing at the concrete apartment and families waiting to catch the ferry. Here, Gunkanjima is transformed into a tourism commodity that recreates the island's glorious past with the notion of furusato (hometown), nostalgia, and community.

4 Sŏ Kyŏngdŏk is a well-known campaigner for and promoter of Korean culture and history, especially in the context of Japan and Korea's memory conflicts, including comfort women and Dokdo issues. He appears regularly on television programmes, news, and in the foreign press in an effort to publicise Japan's misrepresentations and revisionist history.

\section{References}

Anderson, Steve. 2001. "History TV and Popular Memory", in Television Histories: Shaping collective memory in the media age, edited by Gary R. Edgerton and Peter C. Rollins. Lexington: University Press of Kentucky: 19-36.

Andrejevic, Marc. 2007. "Surveillance in the Digital Enclosure". The Communication Review, 10: 295-317.

Dixon, Deborah P., Mark Pendleton, and Carina Fearnley. 2016. "Engaging Hashima: Memory work, site-based affects, and the possibilities of interruption". GeoHumanities, 2 (1): 167-187.

Edgerton, Gary. 2001. "Introduction: Television as Historian: A different kind of history altogether", in Television Histories: Shaping collective memory in the media age, edited by Gary R. Edgerton and Peter C. Rollins. Lexington: University Press of Kentucky: 1-16.

Han, Jung-sun. 2016. "Relics of Empire Underground: The making of dark heritage in contemporary Japan”. Asian Studies Review, 40 (2): 287-302.

Hardenbergh, Margot. 2010. "The Death of Television". ETC: A Review of General Semantics, 67 (2): 170-176.

Kal, Hong. 2008. "Commemoration and the Construction of Nationalism: War memorial museums in Korea and Japan". The Asia Pacific Journal: Japan Focus. apjjf.org/Hong-KAL/2880/article.html.

Lim, Jie-hyun. 2010. "Victimhood, Nationalism and History Reconciliation in East Asia". History Compass, 8: 1-10.

Lowenthal, David. 1985. The Past is a Foreign Country. Cambridge: Cambridge University Press.

Lozano, Juan F. 2013. "Television Memory after the End of Television History?" in After the Break: Television theory today, edited by Marijke de Valck and Jan Teurlings. Amsterdam: Amsterdam University Press: 131-144. 
Ministry of Foreign Affairs. 2015. "Decision to Record the Heritage of Japan's Meiji Industrial Revolution: Iron and steel, shipbuilding and coal mining in the UNESCO World Heritage List”. www.mofa.go.jp/mofaj/pr_pd/mcc/page3_001285.html.

Nagasaki zainichi chōsenjin no jinken o mamoru kai [The Association to protect the human rights of resident Koreans in Nagasaki]. 2016. Gunkanjima ni mimi o sumaseba - Hashima ni kyōsei renkōsareta chōsenjin chūgokujin no kiroku [Straining to Hear Gunkanjima: Records of the Koreans and Chinese forcibly mobilised to Hashima]. Tokyo: Shakai Hyōronsha.

Palmer, David. 2017. "Gunkanjima/Battleship Island, Nagasaki: World heritage historical site or urban ruins tourist attraction?" The Asia Pacific Journal: Japan Focus, 16 (1): 4. apjjf.org/2018/01/Palmer.html.

Sawada, Chiho. 2016. "The Promise and Limits of Pop Culture Diplomacy in East Asia: Contexts-texts-reception", in Divided Lenses: Screen memories of war in East Asia, edited by Michael Berry and Chiho Sawada. Honolulu: University of Hawai'i Press: 220-251.

Takazane, Yasunori. 2015. 'Should 'Gunkanjima' be a World Heritage Site? - The forgotten scars of Korean forced labor". The Asia-Pacific Journal: Japan Focus, 13 (28): 1. apjjf.org/2015/13/28/Takazane-Yasunori/4340.html.

UNESCO. 2015. "Sites of Japan's Meiji Industrial Revolution: Iron and steel, shipbuilding and coal mining, Japan". whc.unesco.org/en/decisions/6364/document/.

World Heritage Committee. 2015. "Statement by the Korean Delegation". whc.unesco. org/en/sessions/39com/records/?day=2015-07-05\#tMnp-FyTHr-s11825.

Yoshida, Reiji. 2015. "Government Downplays Forced Labor Concession in Winning UNESCO Listing for Industrial Sites". The Japan Times, 6 July. www.japantimes. co.jp/news/2015/07/06/national/history/unesco-decides-to-add-meiji-industrial-sitesto-world-heritage-list/\#.WZUxSVUjGUk. 


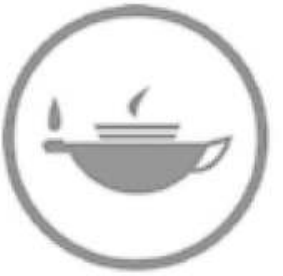

Taylor \& Francis Taylor \& Francis Group http://taylorandfrancis.com 
Part IV

Japan-Korea relations and popular culture engagement 


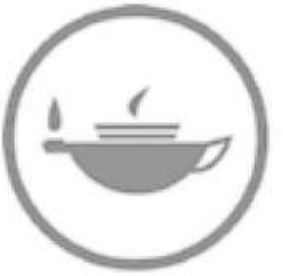

Taylor \& Francis Taylor \& Francis Group http://taylorandfrancis.com 


\title{
10 Lovers' quarrels
}

\section{Japan-Korea relations in amateur Boys' Love manga}

\author{
Rebecca Suter
}

\section{Introduction: the Hetalia Korea controversy}

When Himaruya Hidekaz's comic Axis Powers Hetalia was scheduled to be adapted into TV animation in Japan by Studio Deen in 2009, a group of South Korean readers, objecting to what they described as a demeaning representation of the character "Korea" in the online comic version, sent a petition to the South Korean national parliament asking that the television broadcast of the anime be stopped. The comic had become popular among a niche South Korean audience when it first appeared as an online manga in 2006, and had attracted minor media attention when the character "Korea" made an appearance in 2007. ' Shortly before Hetalia was published in print form in Japan, on 12 January 2008, the online TV channel Why10news had aired a report criticising its negative portrayal of Korea. In particular, the report objected to a comic strip in which the character "Korea" grabs the breasts (or rather, the chest, since the character is male) of the character "Japan" and says they belong to him, which was read as a reference to the territorial dispute surrounding the Dokdo/Takeshima islands, and by extension as a statement that the twin outcroppings belonged to Japan because, like the breasts, they are situated on Japan's "body" (Annett 2014: 188).

Almost exactly a year later, on 10 January 2009, after the production of an animated version was announced in Japan, the issue was taken up again by a group of South Korean citizens who posted a petition on the Internet portal Daum asking their government to demand that the anime production be halted. The petition quickly collected 17,000 signatures; on 14 January, a video aired by the TV network MBC (Munhwa Broadcasting Company) and reposted on YouTube showed National Assemblywoman Chŏng Migyŏng addressing the assembly to denounce Hetalia's slander of Korea. During the session, Chŏng demanded that the Minister of Foreign Affairs officially request KidsTV, the Japanese producer of the animated version, to cancel its broadcast (Annett 2014: 189, Miyake 2012: 254).

In the end, the minister did not raise the issue through diplomatic channels. However, KidsTV decided to suspend the television broadcast of the anime, possibly because of the attention the controversy received online. Furthermore, when the anime came out a few years later as an OVA (original video animation, 


\section{Rebecca Suter}

a cartoon produced directly for sale as DVD or BluRay, rather than for television broadcast), the character of "Korea" did not feature in it at all. On one hand, since "Korea" appeared in only a handful of episodes in the web comic, and was even less present in the print version, we should not overestimate the symbolic value of the decision to remove him from the animated version. On the other hand, in the character's few appearances, his portrayal in the comic did share similarities with negative stereotypes about Korea put forth in the hate speech of netto uyoku (Internet right wing activism) and by Japanese nationalist manga such as Kobayashi Yoshinori's Gomanizumu sengen (Arrogance manifesto, 1993-present) series or Yamano Sharin's Kenkanryū (HateKorean Wave, 2005). ${ }^{2}$

Thus, for example, Korea regularly calls China "older brother" (aniki), which points to his subordinate position in the region. ${ }^{3}$ Furthermore, Korea claims to be the originator of a variety of ideas, objects, and practices, from Confucianism to Japanese swords to the concept of $t$ sundere, ${ }^{4}$ and he draws Japanese anime characters that are identical to the originals, ${ }^{5}$ which can be read as references to Korean nationalist discourse and copyright disputes, respectively. Unlike the manga of Kobayashi and Yamano, however, which show overt contempt for Korean culture, Hetalia focuses only marginally on Korea, and does so in the context of a largely apolitical humour that mocks everyone and everything - first and foremost the eponymous Italia, as well as the character of Japan.

This ambiguity makes the portrayal of Korea in Hetalia an interesting case study for investigating the relationship between popular media and international relations. In particular, the controversy mentioned above shows how the different actors involved, namely authors, readers, fans, anti-fans, institutions, traditional media industries such as television and print publishing, and online media and social media, each have different agendas that intersect in complex ways. As a result, their respective representations and perceptions of stereotypes are based on different frameworks. These different agendas and frameworks need to be scrutinised carefully if we want to understand the role played by popular culture in domestic and international politics. In this chapter, after surveying the textual history of Hetalia and some reasons for its popularity, I analyse the manga's portrayal of "Korea" in relation to national stereotypes and to medium-specific frameworks. In the last section, I look at the portrayal of Korea in a few select examples of Hetalia fan fiction based in the genre of Boys' Love, comics about male-male romances produced by and for young women. I conclude with a reflection on the complexity of the production and consumption of stereotypes in manga, and its implications for understanding the intersection of popular culture and international relations.

\section{Personified nations as kyara}

Himaruya's manga, whose name is a portmanteau of hetare, "good for nothing", and Itaria, Italy, is a series of loosely connected short comics in which the Axis powers (Italy, Germany, and Japan) and the Allied countries (United States, 
Britain, France, Russia, and China) are personified as cute young men. Designed initially with a male audience in mind, the manga gained immediate popularity among female readers, and became the object of a large number of Boys' Love fan fiction adaptations, imagining romantic and sexual relationships between the cute boy nations, as I will discuss in greater detail in the last section of this chapter.

The original web comic, published on Himaruya's website Kitayume, is structured as a series of loosely related yonkoma, or four-vignette strips, rather than as a "story manga", a single coherent narrative that spans several pages. The website includes a main storyline of five chapters, "Hetalia 1", "Hetare 2: Allied Forces", "Hetare 3: G-R Non-aggression pact?" "Hetare 4: Pact of Steel", and "Hetare 5: Lietuvis!!" and two side stories, one focusing on Japan, and one on "Chibitaria", baby Italy and his grandfather Roman Empire. The main episodes are all set during the First and Second World Wars, and they centre on the relationships between the "Axis powers" of the title, with particular focus on hopeless but cute Italia and how he irritates both Germany and Japan with his cowardliness, laziness, and obsession with pasta.

The largest proportion of online comics, however, is constituted by selfstanding bangaihen (extras), short strips unrelated to the main plot, set in different time periods, ranging from antiquity to the contemporary age, and featuring a growing number of personified nations. This lack of a strong plot is consistent with a broader tendency in contemporary Japanese manga to focus on characters' comical or charming personalities rather than on complex stories and is arguably a key reason for the popularity of the comic.

This concept of a shift of interest from narrative to characters among Japanese consumers of popular media was first put forth by Ōtsuka Eiji in Monogatari shōhiron (A theory of narrative consumption, 1989). The book featured an analysis of the 1960s craze among Japanese children for Bikkuriman chokorēto, individually wrapped snacks that each contained a card with a picture and a text listing the name and characteristics of a different imaginary character. Ötsuka argued that the popularity of Bikkuriman snacks was emblematic of a broader change in Japanese society from a modern interest in grand narratives to a postmodern desire for fragmented bits of information that individual consumers could reassemble freely, without having to conform to a dominant narrative (Ōtsuka 2001: 325-326). Also focusing on popular culture consumption, and particularly the subculture of otaku, that is, manga and anime fans, Azuma Hiroki expanded Ōtsuka's analysis and argued that in the 1990s Japanese readers were looking at popular culture as a "database" rather than as a source of narratives. From this perspective, characters in contemporary manga, which Azuma refers to as kyara, come to perform a similar function to the ones on the Bikkuriman trading cards. Readers of manga, Azuma argues, derive pleasure in collecting information about the characters as a way of developing their cultural capital, rather than following their stories. As a result, readers increasingly lose interest in narratives, and publishers produce texts where the plot is less important than the kyara (Azuma 2001: 38-45, 2009: 47-57; see also Galbraith 


\section{Rebecca Suter}

2014b, LaMarre 2009: 258-260). If we keep in mind that this is the context in which Hetalia emerged, we can attain a more nuanced interpretation of its portrayal of "Korea".

In Tezuka izu deddo: hirakareta manga hyōgenron e (Tezuka is dead: towards an open semiotic theory of manga, 2005), Itō Gō proposed a different interpretation of the popularity of characters and their role in manga consumption. Itō distinguished between kyarakutā, a term used in relation to manga to differentiate its characters from those of literature, theatre, and film, designated by the Japanese word tōjojinbutsu, and kyara, a more recent and more ambiguous term. Through an analysis of the visual construction of the young sea otter protagonist of Igarashi Mikio's manga Bonobono (Bonobono, 1986-present), Itō argues that to be perceived by readers as a kyara, a manga "character", be it human, anthropomorphic animal/plant, or personified object/concept, needs to have at least three characteristics: it must have a somewhat humanoid figure, i.e. possessing eyes, a face, and a recognisable body; it must be addressed in the story with a personal pronoun and/or a proper name; and it must be represented as moving through a sequence of still frames (Itō 2005: 79). Itō argues that in this sense a kyara is best described as a "proto-character", a simpler figure that does not need the psychological depth and complex life-story of a kyarakutā. In Japanese media, the term often refers to characters created directly for merchandising, which do not originally form part of any story, such as Hello Kitty (Itō 2005: 117). However, the combination of face, name, and movement gives a "presence" (sonzaikan) to kyara that the characters of narrative fiction (who lack a visual dimension) and the characters of film and theatre (who are played by real people) cannot achieve. For Itō, manga's kyarakutā are kyara with the addition of a back story and an everyday life, which gives them greater complexity. Thanks to the fact that manga characters have an "inner kyara", however, readers are better able to imagine them as having a "life beyond the page", which makes them more real, even if they are creatures that do not exist in the actual world, such as robots or fairies (Itō 2005: 120-126). Both kyara's "presence" and kyarakutā's life beyond the page play an important role in the development of Hetalia in the realm of fan fiction, as I will discuss in further detail in the last section.

More recently, Marc Steinberg has studied Japanese audiences' fascination with kyara in light of the connections between manga still images, their animated versions, and the reoccurrence of these images in character merchandising that lie at the core of what he describes as Japan's "anime media-mix". Based on a close analysis of industry case studies such as a 1960s marketing campaign for Meiji Seika Marble Chocolates, which relied on the use of stickers featuring the eponymous character from Tezuka Osamu's Tetsuwan Atomu (Mighty Atom, translated into English as Astroboy, and appearing as a manga from 1952 to 1968 , and in anime form from 1963 to 1966), Steinberg discusses the implications of Japanese media-mix production on the affective relationship of consumers and fans with popular media products, something that is essential to understand the dynamics of consumption of a manga such as Hetalia. 
In particular, Steinberg examines the production of desire for anime-related merchandising, arguing that such desire is generated "not only through the visual appeal of the character ... or the communicational channels the character opens", but also, importantly, it "depends in large part on the material ubiquity of the character image and its proliferation across media forms" (Steinberg 2012: 42). For Steinberg, this process relies largely on the fact that "the consistency of the image was maintained and dynamised by the particular relation between stillness and motion found in the television anime" (Steinberg 2012: 42). Conversely, "it was this sticker boom that was in part responsible for the success of anime as a medium organised around the practice of character merchandising and its serial proliferation of character images" (Steinberg 2012: 43). The affective relation with characters created through the manga-anime-merchandising connection is a central element in the production of what is known as the moe effect, which I discuss in the next section with special attention to its impact upon relations with Korea.

Hetalia is a paramount example of the dynamics analysed by Ōtsuka, Azuma, Itō, and Steinberg. The loose narrative structure of the original comic and the configuration of the Kitayume website, which lists the comics according to nonnarrative, non-chronological categories, actively encourage a database-style consumption and a focus on the nations as kyara. The print version of the comic, serialised in the seinen (young adult) manga magazine Gekkan komikku bāzu (Monthly Comic Birz) in 2006-11 and published in volume form (tankōbon) by Gentōsha in 2008, rewrites some of the yonkoma as slightly more structured narratives, but also adds several unrelated episodes that further disrupt the already non-linear narrative. Thus, for example, the first volume of the tankōbon edition opens with a colour insert, entitled "Meeting of the World" and set in the contemporary age, where several European and Asian nations get together to "solve the problems of the world one by one", which is followed seamlessly by an episode set at the beginning of the First World War, without any explanation (Himaruya 2008: Vol. 1: 3). Furthermore, the tankōbon volumes also contain a number of pages devoted to the characters' profiles, similar to those of contemporary pop singers or actors, with a passport-size picture of the character, a list of pieces of information such as the country's language, birthday, and national flower, and a short biography focusing on what they like and dislike. These biographical cards further emphasise the kyara status of the personified nations, enhancing both the fragmented feeling of the texts and a sense of the characters. ${ }^{6}$ What the comic offers its readers is not so much allegories of nations as political entities, but kyara that through their personalities convey a "presence" and trigger an emotional reaction. Within this context, let me now turn to the character of "Korea" in the original Hetalia. Despite the fact that it appears in only a handful of strips, the portrayal of this character can offer useful insight into the concrete circumstances of the production and consumption of national images in the realm of popular culture, and understandings of Korea in Japan, in particular. 


\section{Korea's got moe}

In Himaruya's original manga, the character "Korea" makes only a few appearances and is absent from the animated version. This status is consistent with the secondary role of Asian nations in the comic, which focuses on Europe and North America. Of the over 60 personified nations and territories in the comic, Southeast Asia is represented by only Thailand and Vietnam, while East Asia is reduced to Japan, China, South Korea, and, interestingly, Taiwan, Hong Kong, Macao, and Tibet. While it might be tempting to read their presence as a critique of the national unity of the People's Republic of China, it is important to remember that other characters also have multiple selves - first and foremost Italia, who besides the main character, "Italia-Veneziano" (Italy-Venetian, representing Northern Italy), also appears as Italia-Romano (Italy-Roman, representing Southern Italy), and as a Chibitalia (tiny/baby Italy, representing the country at the time of "grandfather Roman Empire").

The visual representation of Korea shares many similarities with the protagonist Italia. Like Italia and Japan, he is a cute, feminine, and childlike character, with a rounded body, large eyes, and a small chin, features typically associated with neoteny. ${ }^{7}$ The term neoteny comes from biological science, where it refers to a slower-than-normal development of bodily features in humans and animals, which makes them retain a childlike and puppy-like appearance, respectively. In Japanese popular media studies, the term refers to the portrayal of characters with childish and/or animal features and is seen as a factor in the production of the "kyara moe effect", a distinctive emotional investment that fans have in fictional characters, particularly those from manga and anime.

The term moe literally means "budding" and it is used by manga and anime fans to refer to their attraction to kyara, typically ones that display childlike or feminine appearance and behaviour. Because of the perceived connection with its homophone moeru, to burn, the word in this usage has an added connotation of "burning passion". The term can thus appear in verb forms (moeru) or as a noun (moe) and refer to either the reader's emotional reaction to the character ("I feel moe for the kyara"), or the character itself ("the character has moe"). Characteristics that inspire moe in the reader and/or give a character moe include large eyes, a small chin, a head disproportionally large compared with the body, as well as additions such as "cat ears, colored hair, rabbit tails, eyeglasses, costumes or uniforms, and poses, gestures, or situations" (LaMarre 2009: 258). Initially used only among small groups of fans, the term gained broad currency in the mid-2000s, partly thanks to the popularity of the media-mix franchise Densha Otoko (Train Man, novel 2004, film 2005, television drama 2005, manga 2005-06), where the word is uttered by the protagonist, a male otaku, to signify his delight at seeing and acquiring manga and anime merchandise (Galbraith 2014a: 19). A thorough understanding of moe and how it shapes readers' consumption of manga is crucial for interpreting the representation of the characters of Korea, Italy, and Japan in Hetalia. 
Scholars like Azuma Hiroki and Saitō Tamaki use the concept of moe as an analytical category to explain the intense relationship that Japanese manga fans develop with fictional characters and virtual worlds. Azuma sees kyara moe as an effect of the consumption of popular media as database, which prevents either a narrative or an analytical approach to cultural items, leading instead to a purely emotional reaction to the moe elements in them (Azuma 2001: 75; Azuma 2009: 84). Saitō looks at moe through the lens of Lacanian psychoanalysis, particularly the concept of the imaginary realm as a mediating element between subject and external reality, and sees fans' emotional investment in fictional characters as a sign of their enhanced awareness of the imaginary nature of human experience of reality (Saitō 2000, 2011).

Whether we interpret the moe approach to popular culture as self-reflexive or as purely affective, it remains based on a fundamental ambiguity. On one hand, presenting and perceiving characters as cute, feminine, animal-like, and childlike distances them and makes them "other", an object of consumption. On the other hand, the emotional connection experienced by the audience makes the characters closer to the self, an object of identification. As manga fan and cosplay practitioner Momoi Halko notes in her interview with Patrick Galbraith, the moe effect is also central to cosplay, the practice of dressing as manga and anime characters, which blurs the distinction between subject and object of consumption:

You could define moe as guys that are in love with fictional girl characters, but it's more complicated than that. For example, men who feel moe for characters might cross-dress or decorate their bags with cute keychains or wear cat ears to events... Lots of men cosplay as the cute girl characters from this series [Toho project, a videogame series]. More than a desire to date a cute girl or anime character, it is a desire to become her.

(Galbraith 2014a: 75-76)

Moreover, cosplay, as demonstrated by Toshio Miyake's ethnographic study of the phenomenon, is also a central component of the appropriation of Hetalia by female fans of Boys' Love manga (Miyake 2016), and, by extension, of their perception and representation of the character of "Korea", as we will see in the concluding section.

While the term moe was used at first mainly to describe the attachment to bishojo, cute girl characters, on the part of otaku, in the new millennium it has also been appropriated by fujoshi ("rotten girls", female fans of Boys' Love manga) to refer to their passion for watching bishonen (cute boys, the male equivalent of bishōjo) characters seduce each other in the texts, and, by extension, for imagining bromances between fictional or real-life characters, a practice known as yaoi megane, "looking at the world through Boys' Love eyeglasses". This shift of gender and genre is a continuation of the initial trajectory of kyara moe fandom, which was coterminous with the emergence of male fandom for shojo manga characters. Patrick Galbraith traces the emergence of otaku's 
passion for bishōjo back to the works of Azuma Hideo in the late 1970s, which "combined the rounded character bodies associated with Tezuka's manga with the expressive faces associated with shojo [sic] manga (manga for girls), which resulted in a hybrid known as the bishojo, meaning cute girl" (Galbraith 2014a: 11). The popularity of bishōjo characters in science fiction manga and anime series $^{8}$ created a young male fan base of cute girl kyara and romantic narratives, which resulted in later years in the popularity among a male adult audience of manga and anime series aimed at girls. ${ }^{9}$ Similarly, thanks to its portrayal of the personified nations as pretty boys, Hetalia gained a vast audience beyond the initial intended readership. In this case, the comic's secondary audience was mainly constituted by female kyara moe fans, and this fandom is a particularly fertile terrain for investigating the complex relationship between cultural representations and perceptions, and between the production and consumption of national images.

For example, Korea's reference to China as his "aniki", which above I proposed to read as a political metaphor signifying the country's subordinate position in the region, takes on a very different meaning if we put on yaoi megane, as this dependent relationship with the character China further contributes to the moe-fication of Korea in Hetalia. Korea shares this feature with the other two cute and hopeless characters in the story, Italy, who is in a dependent relationship with Germany, and Japan, who is similarly attached to America. Within a Boys' Love paradigm, Korea's reference to China as aniki becomes a sign of adorable vulnerability, which will likely trigger moe feelings in fujoshi readers. Let me now turn to concrete examples of how the character of "Korea" is framed through Boys' Love kyara moe by female fans of Hetalia.

\section{Korea X Japan}

As I mentioned in the introduction, Hetalia's initial fan base was composed mostly of war history buffs, the majority of whom were young men. Himaruya explained on the Kitayume website at the time how the inspiration for the comic came to him when he noticed that chats on the Japanese online forum 2 channeru focusing on the First and Second World Wars always presented Italy as the weakest nation, the "hetare" that could never do anything right. This observation gave him the idea to create a comedy manga revolving around the concept of "good-for-nothing Italia". Consistently with this origin, many of the comic strips derive their appeal from references to the cultural capital of history "nerds". To quote just one example, a strip in the first volume of the tankōbon edition shows Japan visiting Italy in his homeland and admiring the monuments of Rome. Moved by Japan's enthusiasm for his own art and architecture, Italy insists on giving him a present, which turns out to be an ancient Roman column (Himaruya 2008: 34). This exchange refers to a relatively little-known episode in Japanese history, in which a Japanese scholar of Italian literature, Shimoi Harukichi, endeavoured to persuade Benito Mussolini to donate a monument to the byakkotai (White Tiger force), a group of young samurai from the Aizu domain who 
died tragically in the Boshin War (1868-69), and whose heroism had allegedly impressed the Italian dictator. In 1928, the Italian government presented to Aizu municipality in Fukushima prefecture an ancient Roman column, taken from Pompeii, adorned with a bronze Roman eagle, symbol of the Fascist regime, and a plaque offering a tribute "alla memoria degli eroi di Biaccotai" (to the memory of the byakkotai heroes). ${ }^{10}$ These references to relatively obscure historical facts were an important component of the comic's appeal to its intended audience, male otaku who consumed the manga as a "database" of war history trivia.

But the characterisation of the nations as cute boys soon aroused the interest of a vast secondary audience, that of fujoshi. Himaruya started also to cater to this audience, creating strips that hinted at romances between the bishōnen nations. For example, in the "Buon San Valentino" bangaihen series, Germany, after reading a book on how to date girls, asks Italy out for dinner. As Germany nervously sits on the couch, all dressed up and waiting for his date to arrive, he realises that he has forgotten the most important thing: Italy is a boy! The comedy continues through a series of double-entendres and innuendos, as Germany asks Austria if he can practise with him instead, and Austria refuses, stating that he is too serious for this, while France sends over a manual on the "best way of 'doing it' - among equals". ${ }^{11}$

As a result of its popularity among girl fans, Hetalia became the source of numerous Boys' Love parodies. According to Toshio Miyake, between 2009 and 2011 Hetalia was the most adapted and parodied manga work in Japan, with over 10,000 different titles distributed at amateur markets such as Comiket, including several "Hetalia Only" amateur manga sale and cosplay events (Miyake 2016: 163). While the popularity of the manga peaked in 2011 and has declined since, the production of amateur parodies continues 10 years on. In January 2018, the online store Surugaya listed 4000 print dojinshi (amateur parodies) published in each of 2009 and 2010, 2000 titles in 2011 and 2012, 1000 for 2013-15, and 500 titles for 2016 and 2017 (Surugaya 2018).

Following the conventions of Boys' Love parodies, Hetalia dojinshi imagine romances that pair up two personified nations. The pairing is usually indicated in the title, separating the names of the two partners with an X: Italy X Japan, Germany X France, and so forth. The parodies take many forms, from prose fiction to story manga to single-image drawings, and usually contain explicit descriptions or drawings of sexual acts. Reflecting the original focus of the series, most Japanese dojinshi focus on European nations, pairing them with each other, with America, or with Japan; another common pairing is Japan X America. Korea, typically described as South Korea in the English-language versions, has a more significant presence in foreign language Hetalia döjinshi. Among the Hetalia parodies on fanfiction.net, South Korea appears in 772 entries, in 147 of which he is paired with Japan. Admittedly this number is not so significant, compared with over 5000 entries for Japan, and his 1300 pairings with America. However, possibly thanks to a degree of overlap between the fandom of Korean pop culture and that of manga, the character of South Korea has gained dedicated spaces on the web, like "Kimchi lovers", ${ }^{12}$ described as 
"a Hetalia based community that shows love and appreciation for South Korea" where Korea is the protagonist and "all pairing based [sic] fanfiction is allowed". 13

Interestingly, when paired with Japan, Korea is often presented as what in Boys' Love is called the seme, namely the seducer and the dominant partner. Thus, in the story "Cosplay" in the "World Peace Shipping" series by user Insane Fangirl 4, for example, South Korea replaces all of Japan's clothes with anime costumes as a way of seducing him:

Japan was clad in a bathrobe, a silky sailor moon cosplay outfit clutched in his hands, S. Korea broke out in a huge grin and made his presence known.

"I honestly prefer the sailor mars uniform, red looks better on you", chuckling slightly he skipped his way over to Japan, pulling out the red uniform and shoving it in his arms. Japan was flustered not knowing what to say but after some spluttering he managed to form a coherent sentence,

"Did you do this?! Why?" Japan whipped his head to face the younger mischievous nation, horror evident on his face, the horror was quickly replaced by fear. Korea's facial expression darkened considerably and the younger nation closed the distance between them.

"I wanted to have some fun ... oniisan" he smirked into Japan's ear, enjoying the reactions he got from him as he teased him, Korea had so been looking forward to staying at Japan's home but Japan refused to let him sleep with him. So Korea had formulated a plan. One that would ensure they were closer than ever by the end of this trip.

"Whwhy?" Japan spluttered now completely uncertain of what to do, he could feel a tingle up his spine as Korea's warm breath tickled at the nape of his neck.

"To have some fun of course" the younger nation smirked, lightly fingering the collar of Japan's bathrobe eliciting a slight shudder which widened his smirk. ${ }^{14}$

The seduction continues, with abundant graphic details, until "An almost simultaneous burst from both sent them over the edge, clinging and gasping as they rode out their orgasms". The story's portrayal of Korea, sexually harassing Japan after forcing him to dress as the character Sailor Mars from the series Pretty Girl Warrior Sailor Moon, and the portrayal of Japan, secretly wanting to be harassed by him, causes the offensive elements of the original Hetalia online comic strips to pale in comparison.

Interestingly, the author included a short introduction where she addresses potential criticisms by readers: "Ok so a few things to clear up 'cause i know someone will bring them up". The reproaches that she anticipates are not, however, related to the implied racism or sexism of her portrayal of the characters, or to the possible reinforcement of negative stereotypes about national identity. Rather, they pertain to the consistency of her portrayal of the character with the Hetalia universe, to the overuse of Japanese words in manga-based fan 
fiction as a display of fan cultural capital, and to the narrative coherence and integrity of the story overall:

The request was Korea so i used S. Korea since he's on the official wiki. In this fic Korea occasionally uses oniisan and at one moment uses ittadakimasu BUT i put those in japanese for purpose, they're there to emphasise his point, not for show.

Also i did have a solid plot but my insane imagination reared it's ugly head and led this fic to weird and dark places so $i$ apologise if it seems like random porn. because it is random porn. $[\text { sic }]^{15}$

The story and the attached disclaimer demonstrate the importance of considering the different agendas and different frameworks of the various actors involved in the production, reproduction, and consumption of national stereotypes. For Insane Fangirl 4 and her readers, the primary frame of reference is fan identity and Boys' Love genre conventions. They consume images of Japan and Korea as kyara, not as symbols of national identity, and if they are concerned about the use of cultural stereotypes, it is to defend themselves from potential accusations of "showing off" by throwing in (misspelled) Japanese words. The sexual harassment portrayed in the story, too, is a conventional plot element of soft porn Boys' Love, whereby the seme (seducer/penetrator character) aggressively pursues the $u k e$ (seduced/penetrated character), who initially resists, then gives in and enjoys it. The format is usually popular with readers, and enhances the moe value of the fan fiction, as confirmed by user Tegannau's comment on Insane Fangirl 4's story: "That. Was. HOT. *nosebleed*" (according to manga conventions, a nosebleed is a sign of sexual arousal).

\section{Conclusion: moe as method}

The example of Hetalia and its domestic and international reception demonstrates the need for new analytical paradigms to understand the use of popular culture in international relations in a more nuanced way that takes into account the different positionalities of the various actors involved: authors, readers, fans, anti-fans, industries, and institutions. If we approach these different positionalities in relation to the lens of international relations theory, or nation-based analyses of the culture industry, it becomes difficult to understand them as encompassing a single phenomenon. In the case studies I discuss in this chapter, we see Himaruya's declared intention to address his work to Japanese male "history otaku" via the framework of World War trivia fandom, particularly related to Europe; South Korean fans' reading of the portrayal of the personified nation version of their country through the framework of contemporary xenophobic discourse in Japanese popular media; and English-language fan fiction's representation and consumption of the image of personified South Korea as a sexual aggressor and of personified Japan as willing victim, through the framework of Boys' Love soft porn for an East-Asiaphile female audience. The case 


\section{Rebecca Suter}

of Hetalia and its Boys' Love parodies thus calls for a theoretical model that enables us to combine these different perspectives to account for a greater level of complexity.

In this sense, the concept of moe is a useful starting point, as it helps us move beyond the logic of identification and difference, where we can either see someone as "the other", at a distance, or as "one of us", someone we feel close to and/or identify with. The Boys' Love parodies of the comic show this tendency particularly well. In her analysis of fujoshi fandom of BL manga, Kazumi Nagaike has noted how the "multiple, shifting, and synchronic process of identification" experienced by female readers in the act of reading Boys' Love manga cannot be reduced to either reification or identification, but always comprises both elements (Nagaike 2003: 88). By focusing on bishōnen nations, Hetalia and its parodies take this dynamic into the arena of national identities and differences. In this sense, Korea X Japan Boys' Love parodies, like that written by Insane Fangirl 4, provide us with a useful model to reflect on methodological approaches and research questions that can give a more nuanced understanding of the role of popular culture in international politics and transcend the rigid oppositions that are often the default paradigm in this area.

\section{Notes}

1 www.geocities.jp/himaruya/kra.htm.

2 For an analysis in English of hate speech against Korea on Japanese websites, particularly the online forum 2channeru, see McLelland (2008). For an analysis of Kenkanryū, see Sakamoto and Allen (2007). On netto uyoku, see Sakamoto (2011).

3 See "Britannia Angel" (www.geocities.jp/himaruya/tns.htm) and "Korean-style Massage" (www.geocities.jp/himaruya/knt.htm).

4 See, respectively, the nameless vignette at www.geocities.jp/himaruya $/ \mathrm{kra} . \mathrm{htm}$; "Return my chicken", (www.geocities.jp/himaruya/knt.htm); and "He says he invented that too ..." (www.geocities.jp/himaruya/kra.htm). The term tsundere refers to a stereotypical situation in Japanese popular media whereby a character, often but not necessarily female, acts in a cold way towards another character, as a result of a combination of shyness and attraction. The term is used to refer to both the behaviour and the personality type of the fictional character; it is a personality trait considered popular and a source of moe.

5 See "Let's draw anime!" (www.geocities.jp/himaruya/knc2.html).

6 The six-volume print edition was followed by an original print series, Hetalia World Stars, serialised in Shōnen Jump, one of Japan's most iconic boys' manga magazines, in 2014 and still ongoing in late 2019, that is structured in a similar way. An animated version of Hetalia appeared first online, and then as an OVA (original video animation, anime released directly to DVD) produced by DEEN studio in 2013. The anime consists of five seasons and a total of 120 mini-episodes, that were streamed weekly on the website animate.tv and later released as a DVD set. The anime not only retains the fragmentary structure of the manga, but also exaggerates it through additional cuts and seemingly random montage, shifting the focus even more on the characters, their bickering, and the erotic undertones of the fights. While "Korea" is absent from the animated versions, it returns in some of the fan parodies of the comic, which I discuss in the last section of this chapter.

7 Another distinctive trait of both Korea and Italia that augments their "cuteness" is their ahoge (silly hair) curl, a feature of some personified Hetalia nations that has a 
sort of separate identity from the character: Austria's curl represents an important Austrian tourist destination, the town of Mariazell, Korea's represents "the spirit of Korea", and so forth.

8 See for example series such as Mirai shōnen Konan (Future Boy Conan; 1978), Kidō senshi Gandamu (Mobile Suit Gundam; 1979-80), Chōjikū Yōsai Makurosu (Superdimensional Fortress Macross; 1982-83) and Shinseiki Evangerion (Neon Genesis Evangelion; 1994-95).

9 For example, Bishōjo senshi Sērāmūn (Pretty girl warrior Sailor Moon; manga 1991-97, anime 1992-97), aimed at a viewership of girls but became very popular among a young male audience (Galbraith 2014a: 12).

10 For an analysis of the episode and its implications for the representation and popular perception of Italian fascism in 1920s Japan, see Hoffmann (2015: 32-37).

11 See "Valentino finale" (www.geocities.jp/himaruya/tdn.htm).

12 While the term is used in a derogatory way in other contexts, in this case it is ostensibly meant to express simple attraction to "all things Korean".

13 See www.fanfiction.net/community/Kimchi-Lovers/106964/.

14 See www.fanfiction.net/s/8348260/10/World-Peace-Shipping.

15 www.fanfiction.net/s/8348260/10/World-Peace-Shipping.

\section{References}

Annett, Sandra. 2014. Anime Fan Communities. New York: Palgrave Macmillan.

Azuma, Hiroki. 2001. Dōbutsuka suru posutomodan: Otaku kara mita nihon shakai [The animalisation of postmodernity: Japanese society as viewed by otaku]. Tokyo: Kōdansha.

Azuma, Hiroki. 2009. Otaku: Japan's database animals. Trans. by Abel, Jonathan and Kono Shion. Minneapolis: University of Minnesota Press.

Galbraith, Patrick. 2014a. The Moe Manifesto: An insider's look at the worlds of manga, anime, and gaming. Tokyo: Tuttle Publishing.

Galbraith, Patrick. 2014b. The Otaku Encyclopedia: An insider's guide to the subculture of Cool Japan. Tokyo and New York: Kōdansha International.

Himaruya, Hidekaz. 2008. Axis Powers Hetalia. Tokyo: Gentōsha.

Himaruya, Hidekaz. 2008. "Kitayume”. www.geocities.jp/himaruya/t.html.

Himaruya, Hidekaz. 2013. Axis Powers Hetalia. DVD. Tokyo: Deen Studio.

Hoffmann, Reto. 2015. The Fascist Effect: Japan and Italy, 1915-1952. Ithaca, NY: Cornell University Press.

Itō, Gō. 2005. Tezuka izu deddo: Hirakareta manga hyōgenron e [Tezuka is dead: Towards an open semiotic theory of manga]. Tokyo: NTT Shuppan.

LaMarre, Thomas. 2009. The Anime Machine: A media theory of animation. Minneapolis: University of Minnesota Press.

McLelland, Mark. 2008. “ 'Race' on the Japanese Internet: Discussing Korea and Koreans on '2-Channeru.'” New Media Society, 10 (6): 811-829.

Miyake, Toshio. 2012. "Quando la storia diventa sexy: dal revisionismo storico all'antropomorfismo moe delle nazioni” [When history becomes sexy: from historical revisionism to moe antropomorphism of nations]", in Il Giappone moderno e contemporaneo: Stato, media, processi identitari, edited by Marco Del Bene, Noemi Lanna, Toshio Miyake, and Andrea Revelant. Bologna: I libri di Emil-Odoya University Express: 237-255.

Miyake, Toshio. 2016. "History as Sexualized Parody", in Rewriting History in Manga: Stories for the Nation, edited by Rebecca Suter and Nissim Otmazgin Basingstoke: Palgrave Macmillan: 151-173. 


\section{Rebecca Suter}

Nagaike, Kazumi. 2003. "Perverse Sexualities, Perverse Desires: Representations of female fantasies and yaoi manga as pornography directed at women". U.S.-Japan Women's Journal, 25: 76-103.

Ōtsuka, Eiji. 2001. Teihon monogatari shōhiron [Revised theory of narrative consumption]. Tokyo: Kadokawa shoten.

Saitō, Tamaki. 2000. Sentō bishōjo no seishin bunseki [Psychoanalysis of the beautiful fighting girl]. Tokyo: Ōta shuppan.

Saitō, Tamaki. 2011. Beautiful Fighting Girl. Trans. by Vincent, Keith and Dawn Lawson. Minneapolis: University of Minnesota Press.

Sakamoto, Rumi. 2011. " “Koreans, Go Home!" Internet Nationalism in Contemporary Japan as a Digitally Mediated Subculture". The Asia-Pacific Journal: Japan Focus, 9 (10): 2. apjjf.org/2011/9/10/Rumi-SAKAMOTO/3497/article.html.

Sakamoto, Rumi and Matt Allen. 2007. "Hating 'The Korean Wave' Comic Books: A sign of new nationalism in Japan?" The Asia-Pacific Journal: Japan Focus, 5 (10). apjjf.org/-Rumi-SAKAMOTO/2535/article.html.

Steinberg, Mark. 2012. Anime's Media Mix: Franchising Toys and Characters in Japan. Minneapolis: Minnesota University Press.

Surugaya 2018. www.surugaya.jp/search? category $=1100 \&$ search_word $=\&$ restrict[] $=$ sub genre $=\% \mathrm{E} 3 \% 83 \% 98 \% \mathrm{E} 3 \% 82 \% \mathrm{BF} \% \mathrm{E} 3 \% 83 \% \mathrm{AA} \% \mathrm{E} 3 \% 82 \% \mathrm{~A} 2$. 


\title{
11 Fly the flag (at your own risk) \\ Netizens, nationalism and celebrities \\ between South Korea, Japan and beyond
}

\author{
Stephen Epstein
}

\section{Introduction: not good copy}

On Monday morning, 15 August 2016, Tiffany of K-pop icons Girls' Generation uploaded a Snapchat photo that paid tribute to the group's just completed pair of weekend Tokyo Dome concerts. Applying a graphic overlay available in that social media platform, Tiffany captioned the shot of a handbag of hers as "Tokyo, Japan" with a filter that evoked Japan's Rising Sun Flag. Although the Snapchat image was deleted almost immediately, netizens took screen captures, which were then widely circulated. Reaction to Tiffany's post was swift, but more importantly predictable, as the star met widespread condemnation for her "ignorant" and "thoughtless" action, a blunder significantly exacerbated by its timing on Liberation Day (kwangbokchŏl), which commemorates the end of Japan's occupation of Korea over 70 years prior.

Tiffany, of course, was hardly the first celebrity to be attacked for inattentive display of nation-based imagery in East Asia's sensitive media environment. The South Korean situation is striking, however. As Jeff Kingston (2017: 38) notes in his recent Nationalism in East Asia:

Netizens in Korea, one of the most wired societies anywhere, have become guardians of public mores and the thought police of the 21st century; some seem to have an obsession with the Rising Sun Flag.... Whether as a backdrop for a music video poster, or on designer hoodies and hats, the Rising Sun Flag that conjures up images of Japanese imperialism and brutal subjugation among many Koreans seems to have become the East Asian swastika.

To be sure, as Kingston suggests, examples of Internet criticism of celebrities for appearing together with evocations of the Rising Sun Flag may be considerably multiplied: one might consider, for example, backlash encountered by the groups 2PM and T-ara for performing with similar patterns behind them; by T.O.P. of boy band Big Bang upon being photographed in a jacket emblazoned with a rising sun lapel; or by bandmate G-Dragon, when a picture surfaced of him posing for a Japanese TV show with his face set in a cut-out placard amidst 
alternating red and white rays, reminiscent of the flag that has been made taboo in South Korea. ${ }^{1}$

Kingston goes on to argue that:

Given how assiduously K-pop bands are marketed and the extent to which coordinators choreograph everything about their dance routines, appearances, clothing, diet and private lives, it is hard to imagine that such displays were unwitting. But the Rising Sun Flag is good copy and, after the attention-grabbing ritual apology, the show goes on, hopefully accompanied by rising sales.

(Ibid.)

Jeff Kingston is a prolific and insightful scholar, but in this case, perhaps because he writes from the perspective of a scholar of Japan rather than Korea, he is almost certainly wrong in his assumptions and seriously underestimates the damage to reputation and career that can accrue for a celebrity within South Korea where display of the Rising Sun Flag is anything but good copy. Even innocent actions can land a star in significant trouble. Although some celebrities have shown a startling obliviousness to the potential for imagery in their proximity to be misread, it is instead difficult to presume that these cases were deliberately intended to stir controversy, given how readily they can backfire in an over-determined context of demonisation and sharply drawn lines of normative, expected behaviour.

Tiffany appears to have made her ill-considered post out of a desire to maintain digital contact with an eager fan base, but her lapse of judgement spelled a major blow to her career as one of South Korea's most well-known pop artists. Despite uploading a humble expression of contrition just a few hours later for her mistake (shilsu), her sorrow at causing disappointment (shilmang) among the public, and a promise to engage in deep self-reflection, the furore continued to escalate, and her gaffe ultimately led to dismissal from Sisters' Slam Dunk (Ǒnnidŭr-ǔi sŭllaem tŏngk'ŭ), a popular South Korean TV show. Eventually, she needed to make a second, more self-abasing apology in which she essentially offered an abject confession that she was not an upstanding member of the Korean minjok (ethnos) as she lacked familiarity with even the basics of Korean history (han'gug-ǔi kibonjŏgin yŏksa). ${ }^{2}$ Tiffany has yet to recover entirely from this episode within Korea and now pursues her entertainment career back in the United States, where she, a member of the diaspora, was born and raised.

Such incidents are but the tip of an iceberg of online denunciation of South Korean celebrities for perceived transgressions of rigid nationalist norms: other Rising Sun Flag controversies are perhaps even more instructive in highlighting the level of this aggressive bottom-up policing of desired collective expression. In 2012 Hyeri of K-pop ensemble Girls' Day appeared at an event rehearsal clad in a t-shirt that had been a thank-you gift from Japanese fans for the group's free concert in Sendai after the Tohoku earthquake. The slogan on the clothing read "My Shirt Will Help Japan" and held an image of a heart in which a rising sun 
beamed red and white rays of hope next to the English lettering. Hyeri seems to have understood, reasonably enough, that her choice of apparel implied solidarity with the victims. When photos of her wearing the shirt circulated online, however, Hyeri was attacked, and she soon issued an apology through her agency Dream Tea Entertainment:

I bow my head and sincerely apologize for not being more cautious. I will be sure that this does not happen again in the future ... I simply thought it meant that we should assist the victims of the earthquake in Japan ... I did not recognize the pattern, and this is a blunder for which I have no excuse.

(Allkpop 2012)

A potential evocation of Korea's own past traumas thus nullified Hyeri's display of appreciation to her overseas fans and support for Korea's "close but distant" neighbour after a trauma of its own.

What these incidents have in common is a celebrity being spotted in association, via an item of apparel or otherwise, with a pattern that impugns their standing as proud and knowledgeable Korean patriots, and then being taken to task in online fora. Like Hyeri, Tiffany's apology involved an expression of ignorance, a promise to engage in self-reflection, and an avowal of renewed commitment to the nation and its hegemonic forces of collective identity. In other words, a South Korean entertainer may be willing to raise eyebrows with provocative gestures that will build a fan base, but, pace Kingston, nods to condoning Japan's occupation of Korea are hardly among them, given a public chafing at the bit to sniff out any scent of collaboration. So strong is this tendency that not only overt waving of a flag, but mere proximity to a pattern of colours that is invested with symbolic weight and pursued vigorously as offensive by some impassioned members of society, has proven problematic.

Indeed, a striking escalation in the caution that celebrities need to exercise reflects transformations in the social meanings of popular culture in East Asia. The presence of celebrities as figures that impinge on daily consciousness has increased dramatically in recent decades with ubiquitous media penetration. In parallel fashion, average citizens, especially with the rise of digital platforms that afford convenient venues for anonymous raising of the voice, now regularly express self-righteous satisfaction in speaking nationalist truths of affect to celebrity power, at times in the face of rationality.

Consider, for example, how critique followed singer HyunA and Jang Hyunseung, formerly of the boy band Beast, for wearing matched sweaters that appeared to showcase a Rising Sun Flag image, even though a closer look reveals that the sweaters' image depicts not the flag, but a woman holding a sceptre-like object from atop of which a rose emanates red and white rays (Kpopmap 2017). The predicament they met found a counterpart in June 2018, when actress Ha Yeon-soo posted an image of herself cuddling a monkey in her lap taken in the photo zone of a Russian circus (Kang 2018). Although the alternating crimson and white spokes of the pattern behind her may have shared a 
motif with the Rising Sun Flag, the Cyrillic lettering upon it and the unusual setting made it obvious that the backdrop had no connection with Japan whatsoever. The actress in fact reduced the colour saturation of the photograph to dispel similarities, but to no avail. Zealous netizens took her to task. When she attempted to justify herself with reference to her care in trying to purge the similarity in the markings, she met with aggressive questioning about why she had posted the photo in the first place if she was aware of her countrymen's sensitivities and recognised that the background might provoke negative reactions (Koreaboo 2018).

Why have such incidents become increasingly common in the 2010s? What factors are causing celebrities to become invested with increased value as vessels of national sentiment? Moreover, and crucially, what does such aggressive mobilisation of online censure in the digital era portend for possibilities of reconciliation? As I argue, a growing body of evidence suggests that developments in media user practice make already waning hopes for the ability of popular culture exchange to help promote understanding between South Korea and Japan increasingly unrealistic.

\section{Celebrities, netizens, nation}

In the rest of this chapter, then, I delve deeper into such occurrences in order to examine how transnational consumption of popular culture contributes to relations between South Korea and Japan. More particularly, I both question and highlight how in the local context nationalism intersects with markedly increased celebritisation, which, following Olivier Driessens (2013: 643), I understand as a "long-term structural development" that fosters societal and cultural changes via the mediatisation, personalisation and commodification of celebrity. Indeed, in many ways, at issue here is not so much contested postcolonial memory, as elsewhere in the volume (e.g. the chapters of Lee, Sakamoto, Choo and Choi), but shifts in media consumption that are likely to drive the role that popular culture can play in the transformation of Korea-Japan relations into the twenty-first century.

Such changes include the rise of produsage and an accompanying evolution of relations between fans and celebrities that are then mapped onto templates of national identity. The development of information and communication technologies (ICT) has intersected with broader social structures to create areas of major concern: not only does East Asia currently face an escalation of top-down state surveillance and concomitant loss of individual privacy, but the vigorous discipline from below of figures deemed to represent the nation has also become widespread. In the region generally, and with South Korea as a noteworthy example, celebrities now live under the shadow of panoptic online policing by members of the public. Although such policing may, of course, also occur in offline settings, I treat it here as largely an online phenomenon, as it is precisely ICT that has provided the populace with the ready means to give expression to, and even weaponise, their voices. 
Moreover, Iwabuchi has underlined how such processes have an international aspect: despite the ways in which globalisation, with its accompanying technologies, "undermines exclusionary identities by generating cultural mixing, hybridized identifications, transnational dialogue and cosmopolitan consciousness", multiple modes of cross-border connection also lead to confrontation and an increase in "hate-driven jingoism and commercialized nationalism" (2019: 1). As Olga Fedorenko (2017) discusses in an astute piece for Inter-Asia Cultural Studies, although Hallyu celebrities are marketed overseas as circulating commodities and agents of international capital, they are also expected to be exemplary patriots domestically. The tensions in these roles, she argues, are fundamentally incompatible and make South Korean celebrities liable to controversies that invoke relationships with Hallyu recipient nations, as is being seen with increasing frequency (cf. Tsai 2007).

Such double binds for Korean stars are especially precarious in the case of Japan and have been at least since Bae Yongjoon kick-started Hallyu in Korea's former occupier with his appearance in Winter Sonata. The situation with Japan takes on heightened sensitivity as a result of Korean society's own internal demons and the unfinished business of how to process the issue of those who collaborated with the Japanese (see further Lee in this volume). Bae himself had to navigate carefully the troubled waters around the dispute over Dokdo/Takeshima when asked his views on its ownership; the need to remain a Korean citizen in good standing without alienating his Japanese fans presented a serious dilemma (Kim 2016). In similar fashion, a likely reason that Tiffany's first apology failed to quell the furore over her Snapchat post was its vague phrasing: Tiffany acknowledged her own mistake, but did not mention Japan. Even the second apology, which pointed towards historical issues, said nothing about colonisation or empire. One suspects that SM Entertainment, which manages Girls' Generation, took pains to arrive with her at a wording that would protect its own substantial interests in the Japanese market but ultimately fell short of a satisfactory response.

The local media framework contributes in yet other ways to making these controversies more salient. James Turnbull (2017), for example, has pointed to a significantly higher use of celebrities in advertising in East Asia generally, and in South Korea particularly, than in the West. The country witnesses remarkable investment in popular stars, encapsulated in the term momgap, literally "body price", which indicates the value attached to given celebrities, and the sum they can command for a product endorsement. One way that celebrities enhance this value is by availing themselves of digital platforms' affordances to reach out to fans directly, and the savvy use of ICT, a regularly noted feature of K-pop's global rise, has consequently been yoked to broader structures of affect. The web 2.0 era in the Korean setting has come to engender expectations of mutual engagement between fans and celebrities, not least because it has been wielded so effectively in the marketing of Hallyu stars to overseas audiences.

Such direct engagement with the public that bypasses other media, which has notoriously been taken advantage of by political figures, also enhances closeness 
by enabling a sense of imagined communion and thus functions as a powerful marketing tool. As Elfving-Hwang (2018: 194) writes, "The idols' social media presence is carefully managed and censored where necessary, and often promotes nationalistic discourses that frame the idol as an ideal citizen representing Korea on the international stage". Indeed, as she also points out, this immediacy encourages fans to imagine that they occupy a position of parasocial kinship to celebrities, an envisioned reciprocal relationship. The sense of affinity to stars as object of affection can be akin to that of a sibling or have an avuncular aspect, which leads to the frequent use of terms like nuna fan (an older female fan relative to a younger male) or samch'on fan (an uncle to a younger performer, almost inevitably female).

Perhaps paradoxically, however, with the empowerment of the South Korean celebrity through promotion of (faux) intimacy comes the empowerment of the South Korean fan as well. Jung (2012: [2.1]), in a discussion of K-pop fan activism, notes that "some critics and commentators have coined the term fancom to describe this new form of assertive bottom-up fan activity". Short for "fan company", the term "demonstrates how fans now consider their stars to be subjects whom they keenly manage and systematically guide", which differs from earlier conceptions of fandom that focus on adulation of stars. A recent Korea Herald piece on the rise of the related trend of "fansumers", consumers who use their leverage as fans to affect marketing and the actions of those whom they support, presents the following striking quote: "'I would like to see my idol stars behave well, so that they have as good an influence on fans as we show affection to them', said Lee Hyun-jin, a 31-year-old BTS fan" (Park 2019).

In such a framework, celebrities can feel themselves to be constantly on stage and pressured to select private moments for broadcast. We might well coin the term "auto-paparazzification" to describe this tendency to make behind-thescenes activities public, for as Tiffany's case shows, no matter how carefully monitored a social media presence might be, problems can and do arise. Regardless of best efforts to harness frequent contact for positive results, routine access to celebrities' off-stage lives also permits opportunity for unintended consequences, and feelings of intimate connection to stars in Korea appear to endow fans with belief in their entitlement to discipline celebrities, as they might an errant family member.

We can therefore extend Elfving-Hwang's framework of parasocial kinship and also posit that netizens in South Korea, even those who are not fans of a particular star, meet incentives to imagine collective ownership over celebrities as a public good and to then express their opinions through prosumer engagement. As a result, one finds a significant increase in online activity that brings celebrities in line with communal desires. This activity in turn generates a need for stars to be circumspect in adhering to normative behaviours in multiple ways, including as national subjects. Glimpses of deviations from desired conduct in spontaneous encounters can spark disapproval, with netizens often seeing themselves as acting on behalf of their version of the imagined national community. 
Users of Womad, a feminist website in South Korea, have argued that South Korea's entrenched patriarchal structures make female celebrities like Tiffany more susceptible to reproach for lack of education in perceived sins against conventional patriotic morality. Certainly, when two members of the girl group AOA embarrassed themselves on national television by not recognising a photo of nationalist hero An Chunggŭn, the assassin of Ito Hirobumi (Ko 2016), criticism at times took on a palpably sexist cast. But male stars do also regularly meet with online vitriol, and the primary supraordinate category that Korean celebrities must attend to is nation. Netizen battles over gender inequality in Korea have indeed become heated, with a variety of positions being staked out that range from the misogyny of websites like the right-wing Ilbe to the misandry of the now-defunct Megalia (Steger 2016), but "nation" remains extremely difficult to contest. Censure of Tiffany conveyed the sense that, as a member of the diaspora, she had not received proper education in such commentary as "learning history is more important than maths or English" (suhak yŏngŏ poda yŏksa chungyohada); similarly, the phrase "black-haired foreigner" (kŏmŭnmŏri woegugin), that is, Korean in appearance only, was used to describe her, and she also met with invective that urged her to "get out of Korea" (han'gug-ŭl ttǒnara) (Yi 2016).

Flashpoints of resentment over a celebrity's ambivalent belongings are surfacing with growing frequency as Hallyu stardom becomes stripped of a one-toone equation with South Korean identity; the participation of diaspora Koreans and foreigners in the Hallyu machinery complicates the constellation of celebrity, netizen and nation. We can liken the Othering mechanisms in Tiffany's case to both the anti-fan activity that emerged when American-born Jay Park/Park Jae-beom of 2PM was thought to have insulted Korea (Jung 2012), and the hounding of Epik High's Tablo, whose Canadian citizenship may have allowed him to forego military service but also likely caused many to deny the legitimacy of his Stanford degree (Jung 2012; Shim 2014). In 2018, actor Steven Yeun (Yŏn Sangyŏp), who has primarily made his career in the United States but also had a starring role in Lee Chang-dong's film Burning, found himself embroiled in controversy for "liking" an Instagram photo that director Joe Lynch, with whom Yeun had worked on Mayhem, had posted. In the photo, a pre-adolescent Lynch is clad in a tank-top sporting the Rising Sun pattern, complete with kitschy matching accessories. Yeun's engagement with the image of his colleague without acknowledging the broader symbolism left himself open to attacks that he had to educate himself more about Korea if he wanted to make money there (Hicap 2018). Like Tiffany, Yeun made an initial apology that only drew further criticism; in Yeun's case, reprimands continued because the English and Korean versions had different emphases, with Yeun adding a second paragraph to the English in which he lamented the stampede of character judgement in online firestorms (Yoon 2018). Notably, all these stars are ambiguously placed in relation to the Korean nation, and have encountered the simultaneous veneration and stigmatisation that co-ethnics from North America can elicit in South Korea. Such cases show an unsurprising penchant for policing full membership 
in the national community at the same time as they reveal South Korea as ever more embedded in cosmopolitan demographic webs.

\section{How to read a flag}

Although Hallyu and Hallyu stars have been heralded for their role in fostering South Korean soft power, their contributions towards a more peaceful and cooperative East Asian environment have been far more ambiguous. Perhaps the most remarkable and widely touted example of how popular culture and international relations have intersected in the East Asian context occurred with JYP Entertainment's girl group Twice. At first glance Twice would seem an excellent example of how popular culture can build bridges within the region; their arrival as a major K-pop group has been especially noteworthy because three of the group's members are Japanese and one is from Taiwan. So successful has Twice been that it has become the first serious contender to wrest the title of "the nation's girl group" (kungmin kŏlgŭrup) from Girls' Generation (Pak 2016), a designation all the more striking because of the ensemble's composition.

Nonetheless, Twice has had to achieve its success while also coping with the challenges posed by its transnational appeal. Early on, the group became mired in an incident that shows how flags can serve as lightning rods for expressions of nationalist fervour in East Asia. In a 2015 appearance on the South Korean entertainment show My Little Television, member Chou Tzuyu was photographed with a flag from her native Taiwan displayed by her bunk bed in the group's dorm, along with the t'aegŭkki, the South Korean flag. Not long after, Huang An, a Taiwanese singer who has pursued his career in Mainland China, took Tzuyu to task for contravening the One China policy and claimed that she was agitating for Taiwanese independence. Chinese netizens picked up on his criticism, condemning Tzuyu and JYP Entertainment and calling for a boycott. In order to stay the furore, JYP had Tzuyu issue an apology. The young performer, then only 16, offered similar contrition to Hyeri and Tiffany for the misstep, which was given greater visceral impact by being filmed. Tzuyu, dressed in black, read her apology, accentuated by deep bows of humility, and acknowledged that "the two sides of the strait are one". Although her remorse may have calmed the waters lapping against the People's Republic of China, the action stirred tempestuous waves of emotions within Taiwan itself, which was then on the eve of a presidential election. Anger over the issue and support for Tzuyu had a demonstrable political effect, and surveys after the election indicate that the pro-independence candidate Tsai Ing-wen, although already a clear favourite, received a bounce of an extra percentage point or two as a result of what was widely seen as the heavy-handed response to China's pressure (Chan 2016).

Commentators have examined the ways in which this event reflects the increasingly precarious nature of transnational media flows within East Asia (Lee 2018; Ahn and Lin 2019), but most striking in relation to this chapter's focus is how an incident on South Korean television with a K-pop group had 
political effects for China and Taiwan, leaving Korea largely a bystander in a geopolitical dispute. As students of history will be aware, the Korean peninsula also served as a stage for the Sino-Japanese and Russo-Japanese Wars over a century ago, and the broader dynamics of popular culture in the region increasingly evoke not only memories of a fraught past but may also portend dangerous trigger points for the future.

What does happen when South Korean celebrities display their own flag in this volatile context? The dynamics here are not straightforward: although from a local perspective, waving the flag is a patriotic act, celebrities who travel internationally leave themselves open to criticism abroad. As is growing ever clearer, celebrity use of any flag, even in the background of a photo, has become willynilly a political act that transcends banal nationalism in the context of global pop cultural flows. Display of the t'aegükki in front of an office building may go unnoticed in Seoul; for Hallyu stars to upload pictures of themselves online with that same flag in the frame, however, makes it visible not merely domestically but worldwide, and can take on different meanings beyond South Korea's borders.

Awareness of South Korea's Rising Sun Flag controversies likely heightens the sensitivity of some Japanese netizens towards use of the t'aegǔkki. Earlier in 2015, on 1 March, a national holiday in Korea that commemorates its 1919 independence movement against Japan, Sunny, one of Tiffany's bandmates in Girls' Generation, posted a photo of the South Korean flag to her Instagram account. She added the phrase, often falsely attributed to Churchill: "a nation that forgets its past has no future" (yǒksa-rŭl ijŭn minjok-ege mirae-nŭn öpta). Although her Korean-language message was intended for a domestic audience in its pointers to issues of historical memory and colonialism specifically, the group's popularity meant that the post would be seen elsewhere, including Japan, which is inevitably evoked in an act of Korean patriotism on 1 March. Accordingly, some Japanese fans expressed disappointment and even anger at Sunny's actions: as user Miko._ commented on Sunny's Instagram feed, "If that is the case, don't come to Japan. Don't even eat Japanese food". Such remarks were countered by Korean fans who found Sunny's post admirable and retorted that she was addressing her fellow countrymen and did not mention Japan specifically (Lee 2015).

We might also cite the parallel example of G-Dragon, who, on 15 August 2016, Liberation Day, the same day that Tiffany made her disastrous Snapchat upload, posted an Instagram image of himself seated behind a t'aegŭkki that he was hoisting, albeit without the potentially provocative wording that Sunny had used. Nevertheless, G-Dragon's action also incurred some negative comment from Japan, which grew when some netizens picked up the story and ran with it in order to make it seem an episode of note. We face a methodological problem, however, in assessing the size and impact of such episodes. Certainly, these stars reach a substantial segment of the public: Sunny's initial post attracted almost 170,000 likes and over 15,000 comments; G-Dragon's post has received over 500,000 likes. More interestingly, perhaps, for assessing their ultimate effect is 
to consider routes and spread of circulation. News that Japanese fans rebuked G-Dragon for uploading the South Korean flag seems to have first appeared in South Korea on Insait' '̌ [Insight], an online news magazine (Chŏng 2016), and the story was picked up by a writer for Soompi, a major website for international K-pop fans (Choi 2016). The item heightened the impression first for South Koreans and then for K-pop's global audience of Japanese animosity towards South Korea, even if the negative commentary may have originally been negligible. Moreover, because K-pop is now treated as newsworthy, the story then travelled from Soompi to a venue with a wider brief for its coverage, the International Business Times (John 2016). This media agency itself has met with success but also criticism for its tendency towards tabloid-style clickbait. One perceptive netizen who went by the user name Jax offered the following perceptive comment in reaction to Soompi's circulation of the story:

I went through about 12 hours' worth of comments and the only negative ones I found were from one single person.... The rest all say "happy independence day", "I wish our countries could work more peacefully together", or apologising for the one idiot. Except now, since this article's been published the number of English comments saying "I hate Japan" and worse have skyrocketed. I don't deny that there are some idiots commenting on GD's Insta but if you're going to make an article from every single idiotic comment on an idol's Instagram you'll never stop writing.

The above analysis from JAX, incisive though it may have been, did not abstain from name-calling, and it disappeared when Soompi removed the comments to the article because of their contentious nature. The website's decision to act as a censor in this case underscores the growing difficulty of reasoned debate in a global public sphere with nation-specific passions.

The most noteworthy incident and biggest backlash involving South Korean celebrities and the t'aegŭkki in Japan, however, indicates that from the Japanese perspective the crucial issue is not the flag per se but rather perceived Korean insensitivity to Japan's own symbols of suffering and trauma: in 2018, Jimin, a member of BTS, South Korea's biggest current popular music stars, was spotted wearing a shirt that contained the t'aegŭkki, above which written much more prominently in capitals in English were the words "PATRIOTISM OURHISTORY [sic] LIBERATION KOREA", juxtaposed with an image of a mushroom cloud from the explosion of an atom bomb. After the image came to light, the band's appearance on Japan's TV Asahi was cancelled, and BTS's entertainment company quickly issued an extensive apology. Nevertheless, when the BBC, one of the world's most important media outlets, ran this story, it included provocative passages that also play a role in suggesting callousness, e.g.: " 'What's so wrong about Koreans commemorating National Liberation Day?' said another Korean user on Twitter" (BBC 2018).

Those wishing to bridge the often fiery gulf between South Korea and Japan through popular culture, even if a majority, can find it hard to dampen strong 
emotions like anger, hatred and resentment and capture less attention. By contrast, those opposed to harmony can rely on outrage as tinder to spark interest and to create a sense of the Other as irrational. These online firestorms reveal a serious problem with social media circulation (Pfeffer et al. 2013), as the attention economy finds its least common denominator in sensational headlines that play to affect and give power to shrill voices, even if lonely. Such issues grow even more salient and the rhetoric more pernicious with the ongoing breakdown of traditional media systems, as fake news and rumours spread in ever more global echo chambers that fuel polarisation. Commentators wanting to disseminate a sense of Japan as an implacable enemy to South Korea seek to dredge up negative Japanese posts about what many Koreans view as patriotic acts from their fellow countrymen, while those who wish to demonstrate Korean irrationality in turn point to violent responses that show that Koreans cannot be reasoned with.

\section{Conclusion: when you wish upon a star}

Ultimately, the increased importance and frequency of interaction between celebrities and audiences suggest that controversies like those discussed in this chapter will continue into the future. Furthermore, the instant and regular consumption of not only text but images, which can lend themselves to radically different interpretations, mean that celebrities and those in the public eye must exercise constant vigilance. The ease with which individuals can become strident commentators and create virality returns power to the aggrieved lone wolf. These trends favour those who see the world in black and white, occasionally interspersed with alternating stripes of red. When even patterns of colour become magnets for criticism, and with the increasing penetration of Instagram, Snapchat and YouTube and role of the visual in Korean culture, outrage over an image becomes proxy for the need to think deeply about the complexities of history and the possibilities of moving forward toward genuine reconciliation. What precisely is remembered when a Korean celebrity tweets a disapproved image or performs against a backdrop? In fact, much of what is resuscitated in collective memory as of 2020 appears to be the specifics of not colonial history, but those of the last celebrity scandal along with its consumption.

Earlier optimism that the mutual interpretation of pop culture between South Korea and Japan, including fandom for one another's celebrities, could promote rapprochement increasingly appears misplaced, as growing contact also tosses up significant barriers to reconciliation. Society is witnessing vividly the limits of investment of hope in all-too-fallible human beings, often younger ones whose upbringing within the entertainment industry may have provided a modicum of media training but neglected broad exposure to the standardised national education curriculum, let alone coping mechanisms for dealing with widespread abuse from netizens. East Asia's online environments, not least in South Korea, have developed a reputation regionally and internationally as toxic and unforgiving, and serious consequences for the individual celebrity can accrue, as has been strikingly underscored by the recent suicides of K-pop idols 
Jonghyun, Sulli and Goo Hara, which made headlines worldwide. Their deaths cast a harsh light on Korea's existing problems with cyberbullying and mental health, which have been exacerbated for celebrities, who in addition to the pressures of attempting to succeed and the micromanaging they face from their own agencies, "are constantly being monitored, adored, and scrutinized by hundreds of thousands of anonymous individuals online" (Saeji et al. 2018).

The intensity of scrutiny has negative implications for digital discourse itself. Changes in online practice both locally and globally over the last decade suggest that controversies will continue to appear and inflame tensions, as voices of outrage acquire greater currency in the attention economy, and small minorities with axes to grind have the opportunity to whet them and swing them at their targets as (virtual) distance declines. The heated passions that these controversies excite, the expanded ability of individuals to fuel nationalist flames, and the speed with which they can spread as online firestorms should give observers pause. And while online expressions of outrage at celebrities are hardly rare at a global level, the incidents in which stars in East Asia become involved do seem to present distinguishing characteristics. Instances of Western celebrities causing unwitting offence or disappointment to their own nation are rare, and abject apologies almost unheard of. If they wade into the sphere of international relations and are then shamed as non-upstanding citizens for their views, supporters who prefer the celebrity's version of national identity in contested situations stand ready to speak up; battles tend to expose domestic rather than transnational fault lines. ${ }^{3}$

As someone who tends towards faith in the goodness of people at large, I retain confidence in the ability of individuals to discover common ground in face-to-face meetings. Unfortunately, when online interaction replaces direct encounters and social media takes over, encouraging possibilities can be sullied by those who work from a standpoint of hate. In the digital era, popular culture in East Asia has become a security issue, and policymakers will ignore this ever more conspicuous fact at their own peril. Affect and emotion appear to have achieved ascendancy over reason in what increasingly is becoming an age of post-rationality. The newfound ability of nationalistic fans to bicker back and forth in global fora and, crucially, to have it picked up at times by less than responsible media outlets who take the role of bystanders egging on a schoolyard fight is hardly a positive. The English-language passage in actor Steve Yeun's initial apology that was absent from the Korean read:

It does say something about our culture, however, to know that we are all just a thumb swipe away, misplaced like or mindless internet scrolling away from the questioning of your character. Our world on the internet is so fragile that it makes me sad that we use this platform to represent us fully.

(Yoon 2018)

That Yeun had to replace his initial trenchant statement with a blander and more penitent wording under continued pressure from netizens does, I believe, offer eloquent testimony to the thoughtfulness of his point. 


\section{Notes}

1 For a useful roundup of several incidents, including those with T.O.P., G-Dragon, 2PM, HyunA, Jang Hyunseung and Hyeri, see Kpopmap (2017). For the T-ara incident, see Kim (2013).

2 For the full text of the apology, see Digital News Team (2016).

3 Consider, e.g., reaction to the Dixie Chicks' criticism of US involvement in Iraq during the George W. Bush years in the United States (Watson and Burns 2010) or Taika Waititi's challenge to New Zealand's view of itself as a non-racist society (Nairn and Nelson 2018).

\section{References}

Ahn, Ji-Hyun and Tien-wen Lin. 2019. "The Politics of Apology: The 'Tzuyu Scandal' and transnational dynamics of K-pop". The International Communication Gazette, 81 (2): $158-175$.

Allkpop. 2012. "Girl's Day Member Hyeri Apologizes for her Controversial T-shirt". 2 May. www.allkpop.com/article/2012/05/girls-day-member-hyeri-apologizes-for-hercontroversial-t-shirt.

BBC. 2018. "BTS T-Shirt: Japanese TV show cancels BTS appearance over atomic bomb shirt". 9 November. www.bbc.com/news/world-asia-46147777.

Chan, Minnie. 2016. "Teen Pop Star Chou Tzu-yu's Apology for Waving Taiwan Flag Swayed Young Voters for DPP”. South China Morning Post, 17 January. www.scmp. com/news/china/policies-politics/article/1902195/teen-pop-star-chou-tzu-yus-apologywaving-taiwan-flag.

Choi, R. 2016. "G-Dragon Receives Backlash from Japanese Fans after Uploading Korean Flag". Soompi, 16 August. www.soompi.com/2016/08/15/g-dragon-receivesbacklash-japanese-fans-uploading-korean-flag/.

Chŏng, Ünhye. 2016. "Kwangbokchŏl t'aegŭkki ollin chidŭraegon-ege akp'ǔl namgin ilbon p'aendŭl [Japanese fans' negative reaction to G-Dragon's Liberation Day post of Korean flag]". Insait' $\breve{u}$ [Insight], 16 August. www.insight.co.kr/newsRead.php?Art $\mathrm{No}=72070$.

Digital News Team. 2016. “T'ip'ani, 2ch'a chap'il sagwamun konggae 'cheil sojunghange mwŏnji kkaedara' [Tiffany's second apology: 'I've realised what is most precious']". AsiaToday, 27 August. www.asiatoday.co.kr/view.php?key=20160826002 253012.

Driessens, Olivier. 2013. "The Celebritization of Society and Culture: Understanding the structural dynamics of celebrity culture". International Journal of Cultural Studies, 16 (6): 641-657.

Elfving-Hwang, Joanna. 2018. "K-pop Idols, Artificial Beauty and Affective Fan Relationships in South Korea", in the Routledge Handbook of Celebrity Studies, edited by Anthony Elliott. London and New York: Routledge: 190-201.

Fedorenko, Olga. 2017. "Korean-Wave Celebrities between Global Capital and Regional Nationalisms". Inter-Asia Cultural Studies, 18 (4): 498-517.

Hicap, Jonah. 2018. "Steven Yeun Refuses Cannes Interviews after Being Slammed for Liking Japanese Rising Sun Flag Photo". Metro, 16 May. metro.co.uk/2018/05/16/ steven-yeun-refuses-cannes-interviews-after-being-slammed-for-liking-japaneserising-sun-flag-photo-7549332/.

Iwabuchi Koichi. 2019. "Globalization, Digitalization, Renationalization: Some reflections from Japanese cases”. Situations, 12 (1): 1-22. 
John, Simi. 2016. "BIGBANG's G-Dragon Slammed by Japanese Fans for Uploading Korean Flag on Instagram". International Business Times, 16 August. www.ibtimes.sg/ bigbangs-g-dragon-slammed-by-japanese-fans-uploading-korean-flag-instagram-2790.

Jung, Sun. 2012. "Fan Activism, Cybervigilantism, and Othering Mechanisms in K-pop Fandom", in "Transformative Works and Fan Activism", edited by Henry Jenkins and Sangita Shresthova, special issue, Transformative Works and Cultures, 10. journal. transformativeworks.org/index.php/twc/article/view/300/287.

Kang, Kyŏnggyun. 2018. "Ha yŏnsu chŏnbŏmgi SNS sajin uihog-e haemyŏng ... kyŏlguk sakjech'ul [Ha Yeon-soo explains suspected social media posting of Rising Sun Flag ... and ultimately deletes]". SBS News, 30 July. news.sbs.co.kr/news/endPage. do?news_id=N1004868834.

Kim, J. 2013. "T-ara N4 Under Fire for Using Japanese Imperialism Symbol in Countryside Diaries MV", Soompi, 2 May. www.soompi.com/2013/05/01/t-ara-n4-under-firefor-using-japanese-imperialism-symbol-in-countryside-diaries-mv/.

Kim, Min-gyeong [Kim Mingyŏng]. 2016 (2005). "Lead Us Not Into Temptation: Entertainment and politics", in The Korean Wave: A Sourcebook, edited by Yun Mi Hwang and Stephen Epstein. Seongnam: The Academy of Korean Studies Press: 220-222.

Kingston, Jeff. 2017. Nationalism in Asia: A history since 1945. Malden, MA: Wiley Blackwell.

Ko, Dong-hwan. 2016. "Singers Shamed over Poor History Knowledge". The Korea Times, 12 May. www.koreatimes.co.kr/www/news/culture/2016/05/201_204620.html.

Koreaboo. 2018. "Ha Yeon Soo Under Fire for Uploading Controversial Photo and an Insensitive Explanation". 30 July. www.koreaboo.com/news/ha-yeon-soo-controversialphoto-insensitive-explanation/.

Kpopmap. 2017. “10 Things: Kpop idols who offended Korea about Japan”. www. kpopmap.com/10-things-kpop-idols-offended-korea-japan/.

Lee, J. 2015. "Japanese and Korean K-pop Fans Clash over Sunny". The Korea Times, 1 March. www.koreatimes.co.kr/www/nation/2019/11/511_174352.html.

Lee, Jooyoun. 2018. "Korean Popular Culture and Historical Sensibilities in East Asia". Arts and International Affairs, 3 (1): 5. theartsjournal.net/2018/05/14/jooyoun-lee/

Nairn, Angelique and Frances Nelson. 2018. "Harnessing Celebrity to Fight Casual Racism: A thematic analysis of responses to Taika Waititi's 'Give Nothing to Racism' campaign", in Personas and Places: Negotiating Myths, Stereotypes and National Identities, edited by Jackie Raphael and Celia Lam. Toronto and New York: Waterhill Publishing.

Pak, Yŏngung. 2016. "Tŭwaisŭ 'Kungmin kŏlgŭrupyo? Tebwihanji kat 1nyŏn ... ŏlttŏlttŏlhaeyo' [Twice: 'The nation's girl group? It's only a year since our debut ... that's puzzling']". Sports Chosun, 26 February. news.chosun.com/site/data/html dir/2017/02/26/2017022600521.html.

Park, Yuna. 2019. “'Fansumers' Emerge as Social Media Power Brokers”. Korea Herald, 31 December. www.koreaherald.com/view.php?ud=20191231000224.

Pfeffer, Jürgen, Thomas Zorbach and Kathleen M. Carley. 2013. "Understanding Online Firestorms: Negative word-of-mouth dynamics in social media networks". Journal of Marketing Communications, 20 (1-2): 117-128.

Saeji, Cedarbough T., Gina Choi, Darby Salinger, Guy Shababo, Elliot Y.N. Cheung, Ali Khalaf, Tessa Owens and Kyle Tang. 2018. "Regulating the Idol: The life and death of a South Korean popular music star". The Asia-Pacific Journal: Japan Focus, 16 (13): 3. apjjf.org/2018/13/Saeji.html. 
Shim, Doobo. 2014. "The Cyber Bullying of Pop Star Tablo and South Korean Society: Hegemonic discourses on educational background and military service". Acta Koreana, 17 (1): 479-504.

Steger, Isabella. 2016. "An Epic Battle Between Feminism and Deep-seated Misogyny is Under Way in South Korea". Quartz, 24 October. qz.com/801067/an-epic-battlebetween-feminism-and-deep-seated-misogyny-is-under-way-in-south-korea/.

Tsai, Eva. 2007. "Caught in the Terrains: An inter-referential inquiry of trans-border stardom and fandom". Inter-Asia Cultural Studies, 8 (1): 135-154.

Turnbull, James. 2017. "Just Beautiful People Holding a Bottle: The driving forces behind South Korea's love of celebrity endorsement". Celebrity Studies, 8 (1): $128-135$.

Watson, Jada and Lori Burns. 2010. "Resisting Exile and Asserting Musical Voice: The Dixie Chicks are 'not ready to make nice'". Popular Music, 29 (3): 325-350.

Yi Anna. 2016. “T'ip'ani, ‘kŏmŭnmŏri woegugin' nollan ch'okpal [Tiffany sparks 'blackhaired foreigner controversy]". Updownnews, 15 August. www.updownnews.co.kr/ news/articleView.html?idxno=60059.

Yoon Minshik. 2018. "Steven Yeun's Flag Controversy Grows Despite Apology”. The Korea Herald, 13 May. www.koreaherald.com/view.php?ud=20180513000245. 


\title{
12 Japanese inherited responsibility, popular narratives and memory of the war
}

\author{
Ria Shibata
}

\section{Inherited responsibility for historical injustices}

Groups and nations in conflict often construct opposing interpretations of the past, particularly if that history involves violent or immoral acts. Polarised memories of past violence can perpetuate a sense of grievance, thereby prolonging conflict between a former perpetrator and victim (Nadler and Shnabel 2008; Frijda 1994). Competing narratives between different parties about the same historical event can become a major hindrance to the peaceful resolution of a conflict (Bilali and Ross 2012). How both perpetrator and victimised groups deal with past histories of violent trauma is therefore critical to the successful resolution of seemingly intractable conflicts (Staub 1998; Lederach 1997; Brooks 1999; Minow 2002). In the case of genocide or war, when injustices are left unacknowledged, feelings of victimisation, shame and humiliation frequently prolong conflict between transgressor and transgressed (Scheff 1994; Lindner 2006; Nadler and Shnabel 2008). The perpetrator's acknowledgement of responsibility for an immoral past is therefore an essential prerequisite for promoting intergroup reconciliation (Minow 1998; Kelman 2008; Shibata 2018).

In the debate on redressing past injustices, some have questioned whether responsibility and guilt for past wrongs should be passed on from perpetrators to descendants. For example, in his commemorative war message (2015) Japanese Prime Minister Abe Shinzo asserted, "We must not let our children, grandchildren, and even further generations to come, who have nothing to do with the war, be predestined to apologise". This statement suggests that it is uncommon for descendants of perpetrator groups to accept "inherited responsibility" for suffering inflicted by their forebears. On the other hand, some theorists argue that the descendants of perpetrators, as members of the same political communities, still bear "inherited responsibility" for a nation's past harms and should thereby contribute in some way to redress those harms (Miller 2007; Abdel-Nour 2013). Such scholars would insist that "inherited responsibility" needs to be seriously addressed if there is to be a "thick" reconciliation in Northeast Asia (Kwak and Nobles 2013: 4).

Japan's lack of contrition, represented by the nationalists' denial of the Japanese Imperial Army's coercion of the "comfort women", the Nanjing Massacre, 
and the Japanese Prime Ministers' visits to the controversial Yasukuni Shrine, continues to fuel tensions within East Asia (Dudden 2008; Clements 2018). The majority of Koreans and Chinese blame Japanese historical "amnesia" and a lack of sincere remorse for past harms as the key justification for their own longstanding anti-Japanese sentiments. Nations and groups remember histories through cultural narratives, rituals and memorials. As a result, if a nation's elites do not want to be reminded of shameful acts that threaten their moral image and identity, then they may deliberately and collectively "forget" uncomfortable historical memories in their master narratives (Shibata 2017: 9; Branscombe and Miron 2004). Buckley-Zistel (2006) describes "chosen amnesia" as a mode of forgetting, by which members of a society purposefully remove unwanted or unsavoury aspects of their nation's past. Scholars such as Seaton (2007), however, argue that the term "amnesia" does not adequately account for the complexity of Japan's contested war memories and competing historical narratives. He argues that rather than "amnesia", the term "selective historical gaze" would be more accurate in explaining the diverse interpretations of war history in Japan (Seaton 2007: 150). South Korea and Japan have different interpretations of the same war history and distinct narratives attached to those histories. These competing narratives of the past play a critical role in prolonging the conflict and fuelling tensions between the two countries. One of the purposes of this chapter is to understand how present-day Japanese, who were not direct participants of the war, understand and make sense of Japan's colonial and war memories.

\section{Identity and collective memory}

Collective memory can be defined as social representations or shared knowledge of a past that may not have been personally experienced, but rather is collectively constructed, transmitted and recalled by members of a society through formal and non-formal communications (Paez and Liu 2011; Moscovici 1988). Collective memory can be disseminated via institutional channels such as official history textbooks, national commemorations, rituals and museums, and at a grassroots level, through popular cultural products, mass media and interpersonal storytelling (Paez and Liu 2011; Bilali and Ross 2012). A group's representation of history defines its sense of its past and future selves and therefore becomes a critical component in the construction of its identity (Liu and Hilton 2005).

When a group's identity is threatened, collective memory can be employed to valorise and restore its collective esteem. Historical memory has been found to be a critical component in prolonging conflicts between groups and nations that have experienced histories of violent trauma and injustice (Bar-Tal 2000, 2003). According to social identity theory (Tajfel and Turner 1986), individuals are motivated to perceive their in-group favourably. Because historical memory is the essential core of a group's identity, perpetrator groups may avoid remembering their past in any way that threatens their moral identity and places them in 


\section{Ria Shibata}

shame (Volkan 2001; Baumeister and Hastings 1997; Shibata 2017). Studies have also shown that groups in conflict often have disparate interpretations of shared histories and distinct narratives attached to those histories. In the face of a shameful past, perpetrator groups may defend their positive identity by deleting or altering accounts of past injustices from their master narratives (Shibata 2017: 9). Collective "forgetting" of past injustices may then come to be seen as a perpetrator group's conscious decision to defend its collective esteem. Volpato and Licata (2010) argue that "collective amnesia" is a common phenomenon and a key aspect of nation-building in many post-colonial societies. This dynamic generates conflicting narratives between perpetrator and victim groups about the same historical event (Bar-Tal 2003; Hammack 2008).

Another way in which a perpetrator group can protect its esteem is by reinforcing narratives about its own victimisation, that members of the group have been subjected to greater injustice and that their suffering is more unique (Noor et al. 2012). Myths about pains and humiliation from historical trauma are an essential part of a nation's identity, which are then disseminated through socialisation processes to successive generations (Volkan 2001). Focusing on an in-group's own suffering rather than its harmful actions against others helps defend the moral identity of the in-group (Noor et al. 2008). In this way, both perpetrator and victim groups can construct and perpetuate competing narratives of their own victimisation. The wounds of past trauma are thus maintained and transmitted through the way in which victim narratives are commemorated, the way history is taught, and passed on through various channels, including popular cultural products (Volkan 2001; Shibata 2016). Competitive narratives of victimhood therefore can protract a conflict between perpetrators and victims and become a significant impediment to the process of reconciliation.

\section{Methodology}

The specific aim of this chapter is to explore how historical narratives in domestic popular culture shape the collective memory and understanding of Japan's colonial past by present-day Japanese with specific reference to Japan's actions in relation to Korea. The chapter draws on the assumption that prolonged conflicts are rooted in traumatic memories of violence and that the perpetrator group's acknowledgement of responsibility for injustices is a critical prerequisite to the victims' forgiveness and resulting reconciliation. This study was designed to identify key factors that impact contemporary Japanese acceptance of collective responsibility for the nation's injustices during its history of colonisation before and during the Second World War. To develop a comprehensive understanding of these factors, mixed methods were employed to integrate both quantitative and qualitative data. During the first phase in April 2017, quantitative data was obtained from a survey of 147 Japanese university students in Tokyo and Osaka who were solicited to test a range of variables that may predict Japanese collective responsibility. During the second phase of the study in November 2017, 20 survey participants were selected for semi-structured in-depth 
interviews in order to gain a fuller understanding of the perceptions and experience of contemporary Japanese youth. Use of both quantitative and qualitative methods enabled a more nuanced insight into the behaviour and attitudes of present-day Japanese who were not directly involved in the nation's wartime misdeeds. The chapter addresses the following research questions: (1) How is the history of Japan's colonial injustices presented to contemporary Japanese? (2) How do current generations of Japanese "remember" the Asia-Pacific War through popular culture? (3) How does exposure to narratives that focus on the history of their own nation's victimisation affect younger generations' willingness to accept an inherited responsibility for the colonial aggression of their forebears?

\section{Findings}

Survey respondents were asked to indicate the extent of their awareness regarding Japan's colonial history and wartime aggression. A majority of respondents (59 per cent) answered that they were somewhat aware of Japan's history of wartime atrocities, while a combined 32 per cent stated that they were "not really aware" or "unaware"; 9 per cent regarded themselves as "fully aware" of the historical circumstances. The majority response of "somewhat aware" suggests that most Japanese have at least partial knowledge of Japanese misdeeds during the colonial era and the Second World War.

Qualitative interviews attempted to probe how "somewhat aware" was understood by participants. Respondents explained that junior and high school classes either only hastily touched upon or entirely ignored Japan's history of colonial injustices and wartime aggression. In their view, teachers generally glossed over the topic, and neither the Nanjing Massacre nor "comfort women" were addressed in any depth in classrooms.

\section{Q: To what extent are you aware of the history of Japan's wartime atrocities? [i.e. Comfort Women, Nanjing Massacre, etc.]}

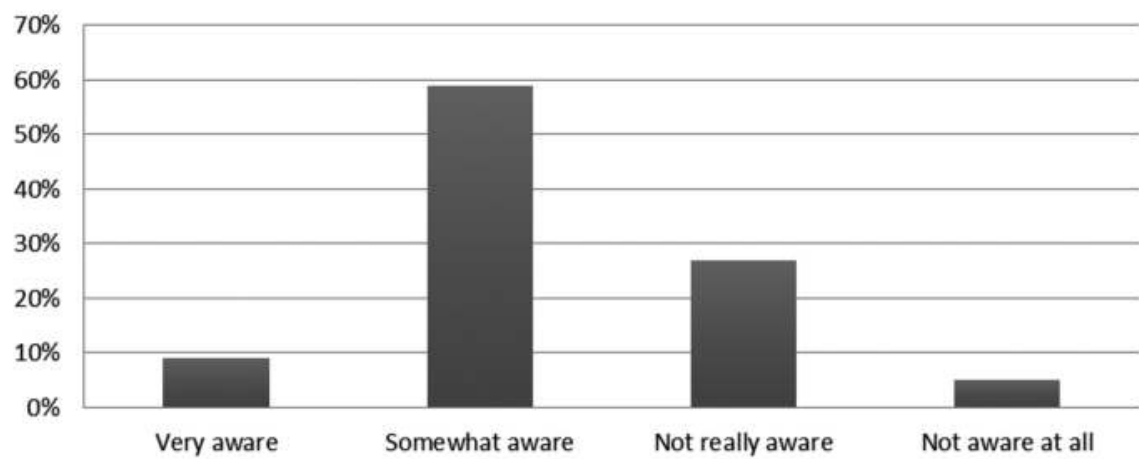

Figure 12.1 Historical awareness of Japan's wartime atrocities. 
KAYOKO: My knowledge of Japan's history of colonisation and the things that the Japanese soldiers committed during the war is very limited. I had never heard of the "comfort women" issue and it was never discussed in our history class in junior high or high school. Normally, the teacher breezed through modern Japanese history because it is not that important for our entrance exams [high school/university].

TATSUYA: I answered, "somewhat aware". I first learned about what the Japanese military did in history class in junior high and high school. In all my history classes, the teacher only briefly mentioned incidents that occurred and never discussed the matter in depth. So, to this day, I don't really know much about what actually happened.

As for knowledge regarding the "comfort women issue", most respondents answered that they hardly remember reading about it in their history textbooks. It should be noted that these respondents were in junior high or high school from roughly 2010-16. Due to the persistent efforts of Prime Minister Abe and his supporters, by 2006 the term "comfort women" was eliminated from the main text of the junior high school textbooks. Moreover, by 2012 reference to "comfort women" disappeared from all junior high school textbooks, including footnotes. For many, the issue surrounding "comfort women" only became known after wide coverage in the domestic media of the dispute between South Korea and Japan over the 2015 bilateral agreement on "comfort women".

YOKO: I had never heard about the "comfort women issue" until I entered college. I was watching the evening news programme on Nippon Television with my mother and grandmother. I don't recall reading or learning about this issue in school textbooks. I had the impression that Japanese television was defending Japan's position and seemed to be introducing only one side, Japan's perspective. So, based on what I learned from TV, many Japanese would feel that South Korea's actions were unfair and not abiding by the agreement and rules of international law. The programme emphasised the fact that South Korea accepted compensation from Japan and signed the agreement, and questions why "comfort women" statues are still around.

Satoko also noted that she had never heard the term "comfort women" in school and only learned about the issue from the news.

SATOKO: The first time I even heard about the "comfort women" issue was on television news. All I remember is the rising tensions between Korea and Japan surrounding this issue. I cannot remember any of the details. I couldn't understand why the Koreans were so overzealous when it comes to this problem. Why were they so angry? ... To me, they seem to be exaggerating the whole thing. 
Kyoko said she did further research on the Internet because she could not quite fathom why Koreans were so upset. She felt that their reaction seemed a little "extreme" and was curious to delve deeper.

KYOKO: When I heard about the Koreans' furious reactions on television, I wondered what "comfort women" are. So, I googled the term. I think I was able to cover most of the facts, although what I found was, after all, information on the Internet.... I read the Wikipedia entry on the "comfort women" and several other online sources but most denied the accuracy of Korea's accusations, or even stressed that they were fabricated. I was surprised that our high school teacher didn't mention the issue in class. The fact that Koreans are unhappy and unwilling to reconcile means that our rationale is probably not acceptable to them. There is a need for us all to find out more and understand this issue in depth.

Kyoko mentioned that she is from Okinawa and that her grandfather experienced the Battle of Okinawa during the Second World War. Seeing her grandfather's resolve to impart war history to future generations, she assumed that Koreans would try to do the same with their history of suffering during Japan's colonisation. She added, "I don't think Koreans are ever going to forget". Interestingly, it should be noted that respondents who reported high levels of collective responsibility in the survey also showed higher levels of awareness and knowledge about injustices committed by Japan during the colonial era and the Pacific War. Most were from Hiroshima, Nagasaki, and Okinawa, where civil society organisations have been making a concerted effort to perpetuate memories of the war, including the Japanese Imperial Army's aggressions. Given Hiroshima and Nagasaki's experience of the atomic bomb and the Battle of Okinawa, the three cities have been making efforts to promote peace education as part of the school curriculum and activities. Several respondents described visiting war museums in Nagasaki or Hiroshima as an experience of awakening. Yukiko and Hayato each describe below how they learned about Japan's dark colonial past from information at the war museums or from peace education programmes:

HAYATO: I learned about the atrocities committed by the Japanese army at an early age ... I was in fifth or sixth grade. There is a war museum in Nagasaki that introduces not only Japanese victimisation but also the history of the Nanjing Massacre, Unit 731 and the "comfort women". I saw these vivid photographic panels that described what Japan did when we colonised our Asian neighbours. I think it is such an important museum. But unfortunately, it never gets introduced in official tour guidebooks or to visitors.

YUKIKO: I lived in Hiroshima from age seven to eighteen. I went through peace education where I was taught about the horrors of war. At first, learning about the horrors of war at such a young age ... seeing animations and movies, photos of atomic bombing and Battle of Okinawa victims was grotesque and simply traumatic. I couldn't sleep and would have nightmares. 
But I also learned about what Japan did during the war. I will always be against war. And if we need to build a healthy relationship with Korea, to prevent war then we should do everything we can to redress their suffering during the war.

The above quotes support survey findings on respondents' information sources about Japan's colonial history: 77 per cent of respondents had learned about the "comfort women" through Japanese news programmes, followed by 70 per cent who learned through Japanese information programmes (TV), and 44 per cent who cited Internet blogs. Only 23 per cent answered that they had been informed by school textbooks. In contrast, 84 per cent of respondents cited that they first learned about the Nanjing Massacre through history textbooks. These findings reflect the efforts of Prime Minister Abe and Japanese historical revisionists to deny state-driven coercion and recruitment of women as sex slaves during the war and completely remove reference to it from junior high school textbooks.

RURIKO: I cannot recall if the issue about the "comfort women" was explained in the textbook. Even if it was, the teacher must have avoided discussing the topic in depth because it's too controversial and he needed to cover a lot of history in a short time.

JIRO: The Genpei War between the Genji and Heike clans is described in much more detail in history textbooks than the Nanjing Massacre, which only appears inside a tiny box at the bottom of a page as a footnote. That made me think that this piece of information is not that important for us to learn. I remember the incident was introduced together with a photo of a soldier on a horse and a line that said, "The surrender of Nanjing". I have no doubt that the massacre must have happened, but nobody really knows how many were killed. In wars things like that happen. It's all part of war. Also, I remember that the reference to Nanjing was written as if it were some kind of heroic act.

Follow-up interviews revealed that references in history textbooks to wartime and colonial injustices tend to be brief or non-existent. Moreover, the education system's emphasis on the rote learning of dates in preparation for exams offers little opportunity to delve into controversial topics such as the "comfort women" or Nanjing Massacre.

The technique of free association, which entails eliciting words or thoughts inspired by a stimulus, was employed during the in-depth interviews when discussing what interviewees "remember" about the Asia-Pacific War. Interviewees were asked to share what came to mind when they thought of "the Pacific War", including words, thoughts and images.

The salience of the victimhood trope in Japanese educational and political institutions (Yoshida 2005; Seaton 2007; Orr 2001) makes it unsurprising that most interviewees first thought of the atomic bombings: 


\section{Q: What comes to mind first when you think of the 'Pacific War'?}

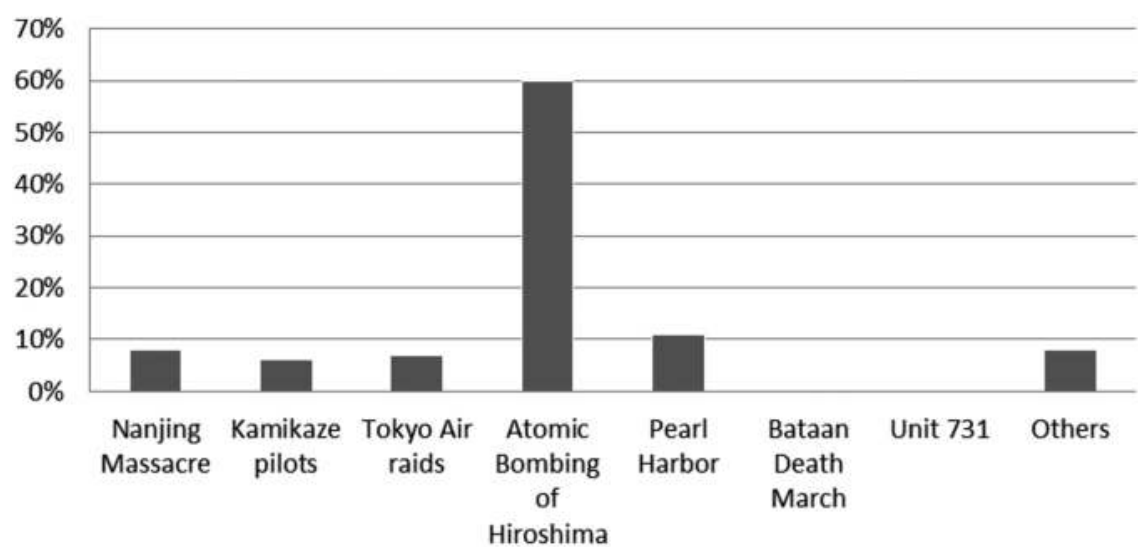

Figure 12.2 Association with the Asia-Pacific War.

SEIJIRO: I think of the atomic bombing of Hiroshima and Nagasaki. A horrifying image of people suffering.

TATSUYA: I feel sad and frustrated when I think about the tragedy of Japan during the war. I also thought of the atomic bombs, firebombs and air raids. TOSHIYUKI: Mushroom clouds from atomic bombs.

HIROMI: I associate the war with the suffering of Japanese civilians and images of the atomic bombing of Hiroshima and air raids. I have watched different television programmes on the war, but what really influenced my understanding was what teachers taught me in elementary and junior high school during history class. The history of the Pacific War was all about Japan's war history. That's why, to me, the Pacific War is about the suffering of the Japanese people. That image is deeply embedded in my mind. Only after I entered college did I learn that the Pacific War was not just about Japan's suffering.

\section{Who are the victims of the Pacific War?}

Interview respondents were then asked who they perceived as victim and victimiser in the Pacific War. Most interviewees who reported low feelings of collective inter-generational responsibility answered that ordinary Japanese people were the victims. For these respondents, the war was automatically associated with scenes of civilian suffering. Some interviewees found the identity of the victimiser more difficult to determine; they believed the Japanese public had little choice regarding mobilisation into the war, and that only a handful of military leaders were culpable. 
EMIKO: The majority of those who supported Japan's war efforts were forced to. Absolute obedience to the Emperor was demanded. Who was responsible for the war? The top political and military leaders of Imperial Japan created the mood of the times.

NAOKI: Class A war criminals should be held accountable for all the evils committed. They were the bad guys.

JIRO: The Pacific War was a war we shouldn't have fought. The military leaders decided to fight a war that could not be won.

TOSHIYUKI: It was just like Germany under the Nazis. The top leaders mobilised the people to believe that the war was sacred and just. Japanese soldiers were influenced by wartime propaganda and went to China, massacred the Chinese and raped the women or used them as "comfort women". It was a top-down decision and the public was forced to obey the military regime. The soldiers were victims of the war, too.

\section{Information sources shaping Japanese war memory}

To gain a better understanding of the processes by which the collective memory of current-day Japanese is shaped by the nation's war narratives, survey participants were asked to choose three sources that they considered to be most important and influential in shaping their views of the Asia-Pacific War. Eightyeight per cent of respondents selected textbooks and school education (teachers) as most prominent; 57 per cent chose television (informational programmes, dramas and documentaries); and 44 per cent selected news programmes.

\section{Narratives of Japanese war memory in popular culture}

To discover how survey respondents had become familiar with public narratives of war, I asked them to elaborate on how and where they learned about Japan's

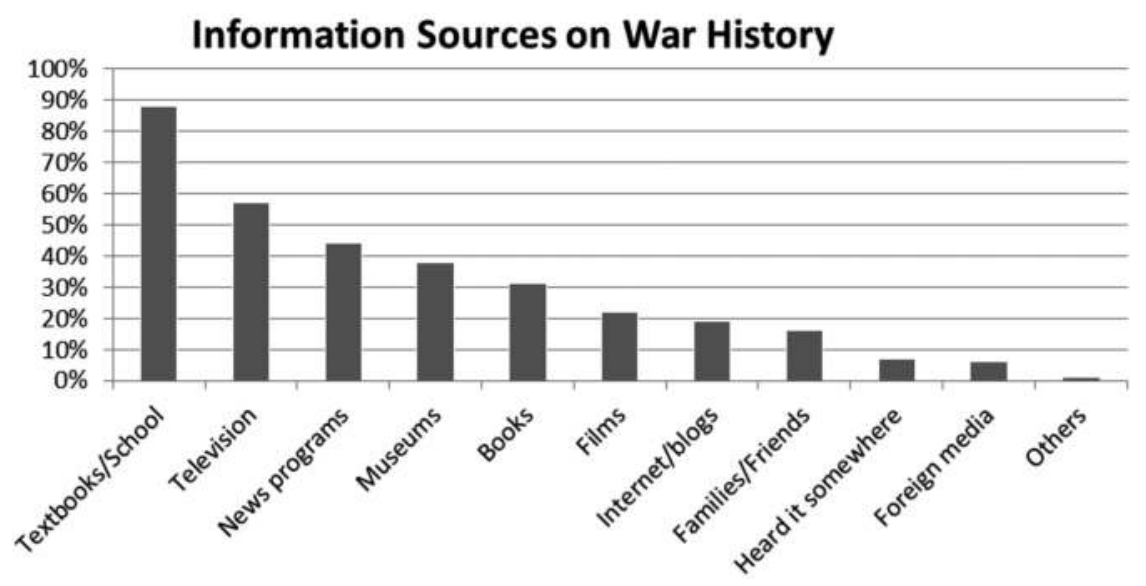

Figure 12.3 Information sources on war history. 
war history. Interview findings revealed that popular cultural products and visual media such as television programmes and films were powerful sources for embedding images of Japanese suffering. The following comments demonstrate how Japanese narratives of civilian victimhood are dominant in Japanese public memory and are communicated via popular cultural products such as literature, films and animations. One text mentioned as a powerful source of Japanese wartime suffering by almost all interviewees was The Grave of the Fireflies (Hotaru no haka), an animated film produced by Studio Ghibli in 1988. Set in Kobe in 1945, this drama, based on an autobiographical essay by Nosaka Akiyuki, focuses on the suffering, starvation and eventual death of 14-year-old Seita and his four-year-old sister, Setsuko. The film vividly portrays these child protagonists as innocent victims of the war.

EMIKO: My image of the war comes from television dramas and animated films like The Grave of the Fireflies. I associate the war with images of people getting fire-bombed. People desperately running to seek safety in bomb shelters as air raid sirens shrieked. They're surrounded by fire, and people around them are suffering and dying. When I think of the war, I can only think of the sight of ordinary people suffering.

YOKO: I watched The Grave of the Fireflies when I was in elementary school. It was absolutely shocking. Until then, I had no knowledge about the hellish aspects of war. It had a powerful impact on me because I have an older brother and I thought Seita and Setsuko could've been us. We should never start a war. It's ordinary people who suffer most.

NAMIE: My family watches war-related programmes that are aired every year in August commemorating the end of the war. Because of the images of these dramas and documentaries, when I think of the war, I immediately associate it with the suffering of Japanese civilians. Until I entered university, I strongly believed that Japan suffered as the victim of World War II. The war to me is about the dropping of the atomic bomb on Hiroshima and Japan becoming a defeated nation. I have no doubt that most Japanese think of themselves as the victims of the war.

Another popular culture product mentioned by interviewees was the television drama Song of the Cane Fields (Satōkibi batake no uta), which aired on TBS (Tokyo Broadcasting System) in 2003 and won the prestigious Grand Prize in the National Arts Festival hosted by the Japanese Agency of Cultural Affairs. The narrative is about "ordinary people's suffering", such as the Hirayama family who are living happily in Okinawa until war breaks out. Hirayama Koichi, played by veteran comedian Akashiya Sanma, faces a moral dilemma when he is forced to shoot a wounded American soldier. As the family leaves the city to seek refuge, Koichi's children are drafted one by one to the Imperial cause. The film is a powerful reminder of the horrors that befell innocent civilians in the infamous Battle of Okinawa. 


\section{Ria Shibata}

AYUKO: My image of the war is associated with air raids and the Battle of Okinawa. I watched Song of the Cane Fields on TV when I was in high school. I couldn't stop crying. It was too sad for words. Because it was a live action film, the suffering of ordinary people in Okinawa felt more "real" to me.

It should be noted that the respondents repeatedly commented on the "suffering of ordinary people", which indicates the extent to which narratives of civilian victimhood are salient in the memory of today's Japanese. Interviewees also noted that the first time they were exposed to facts about the dropping of the atomic bombs was in textbooks, but other sources such as manga, books or animation films left a more indelible impression of the bombings' tragic consequences. Barefoot Gen (Hadashi no Gen), created by Nakazawa Keiji, recounts the bombing of Hiroshima and war aftermath from the perspective of a young boy, Gen; widely read as book and manga series, it was made into an anime film in 1983. Many interviewees remarked that reading the manga or book version in elementary school awakened them to the horrific realities of the bomb and left scarring images in their minds.

SEIJIRO: When I think of the war, I immediately think of the atomic bomb on Hiroshima. I read Barefoot Gen when I was little. That's when I realised how horrible and destructive the bombing was. As I grew older, I gained more knowledge about it. I found Barefoot Gen in the school library. That's how I learned about the horrors of war.

YUJI: I learned general information on the atomic bombing through school textbooks. But I realised how horrible it was when I visited the Hiroshima atomic bomb museum and read Barefoot Gen.

SHINJI: My war image is of the atomic bomb. I think that comes from the book that I read in elementary school called Barefoot Gen. That left a strong impression on me.

SATOKO: I visited Hiroshima with my family, and we went to the atomic bomb museum. I also read Barefoot Gen in elementary school and learned about the horrible tragedy of the children of Hiroshima. It was horrendous.

YUJI: I read Barefoot Gen when I was little. I also learned about what happened through interviews of atomic bomb survivors featured on television.

NAOKI: I think 60 to 70 per cent of my knowledge of Hiroshima is from school textbooks. I found Barefoot Gen in the library in junior high. I started reading it but stopped and never finished because the descriptions were too vivid, and it was too much for me to handle.

EMIKO: When I was in elementary school, we visited the Hiroshima atomic bomb museum and the Dome. I also heard the experiences of bomb survivors and learned about the tragedy through watching various TV dramas about the atomic bombs. I have a close friend from Hiroshima, and she told me in great detail what actually happened to the victims. 


\section{Q: Our generation should bear responsibility for Japan's military actions during the last war.}

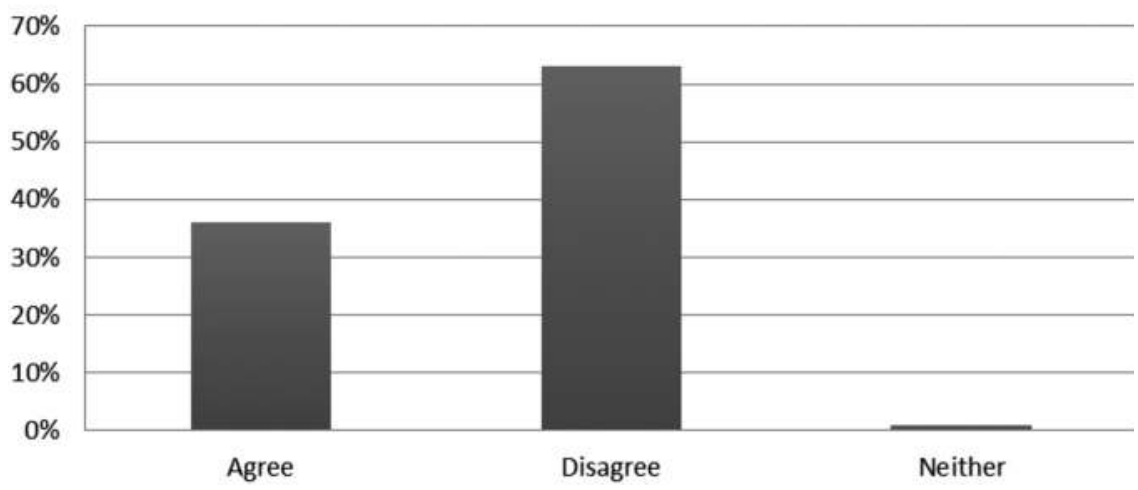

Figure 12.4 Inherited responsibility for Japan's historical injustices.

Note

Scale ranges from 1 to 7 , with higher numbers indicating greater agreement with the items. $N=147$.

These interviewee comments shed light on how Japan's victim mentality is constructed through exposure to specific popular narratives. Although the survey data show textbooks as the dominant source for learning about Japanese war history, findings from the qualitative interviews suggest that the narratives of civilian suffering disseminated through popular cultural channels, such as television, literature, and films, have been at least as influential in promoting the salience of Japanese victimhood.

\section{Disavowal of inherited responsibility}

The previous section explored dominant discourses of Japan's wartime victimhood prevalent in popular cultural products and how they help shape Japanese citizens' collective memory of the war. This section aims to analyse the extent to which contemporary Japanese are willing to accept inherited responsibility for Japan's past injustices in relation to their perception of victimhood. Sixty-three per cent of survey respondents believed that their generation should not have to feel guilty for the mistakes of their forebears, while 36 per cent were willing to accept that responsibility, with 1 per cent undecided.

Importantly, the survey data reveals that those who scored high on victim mentality demonstrated lower levels of willingness to accept responsibility for the nation's wartime injustices. This finding implies that the more salient the victimhood narrative is in Japanese society, the more difficult it is for Japanese to acknowledge responsibility and express continued willingness to redress its past. ${ }^{1}$ 


\section{Ria Shibata}

A dominant opinion that emerges in interviews is the perceived unreasonableness of demands that today's Japanese feel contrition for colonial and wartime misdeeds. A majority of twenty-first-century descendants wish to distance themselves from wartime's imperial, militarised Japan. Their comments demonstrate the attitudes of a generation that feels diminished responsibility for the crimes of its ancestors. They feel that modern Japan differs greatly from the regime that committed cruel atrocities and believe that they should not be held accountable for crimes committed by those with whom they do not identify. Their emotional distance from perpetrators of war crimes and human rights abuses has led them to question whether further apology - made after nearly three generations have passed - is disingenuous, insincere, or even absurd. Consistent with the descriptive survey data in Figure 12.4, interviewees felt frustrated by the expectation of collective blame for atrocities they did not commit.

YUJI: What happened during the war has nothing to do with my generation. We shouldn't be held liable for what other Japanese did a long time ago.

TATSUYA: I don't feel responsible for what happened during the war. I don't see myself as part of the group of militarists who committed those horrible crimes. We're from entirely different generations. I can't feel responsible for something I never took part in. I wasn't even born then. And most of the people who committed the atrocities are dead.

KUNIKO: If the victims asked me to apologise, I probably would ... but in my heart, I'd wonder if the apology has any meaning. I acknowledge that the Japanese committed brutal acts in the past, but I can't feel personal guilt or remorse for what these people did. I wasn't directly involved. That's why I wonder if my apology would have any significance. Would it be considered sincere?

These findings represent the views of 60 per cent of interviewees that presentday Japanese should not have to inherit responsibility for past Japanese misdeeds. Many interviewees were not only perplexed but annoyed with what they perceive as endless South Korean demands for apology and felt that Japan has apologised enough regarding the "comfort women".

SATOKO: How long do we have to continue apologising? Are the victims ever going to be satisfied? I accept that Japan has committed terrible crimes in the past. However, Japan has already apologised often, and even offered a lot of money to the "comfort women". Why do the Koreans keep asking for compensation? I heard that leaders in Korea use the public's anti-Japanese sentiments for their own political agendas.

MIE: Every time the "comfort women" issue comes up, Koreans seem to overreact. Korea is so persistent in its demands. Japan has already issued so many apologies. Why are they dismissed as insincere? I find Korean accusations a bit overblown. 
Such comments echo the "apology fatigue" evident recently in the Japanese public. They also reflect the Japanese government's position regarding the "comfort women" issue - that Japan has already sincerely apologised and expressed remorse, offered reparations and that, furthermore, in 2015 the governments of Japan and South Korea signed a bilateral agreement resolving the issue "finally and irreversibly". This narrative dominates mainstream Japanese media: no matter what Japan does, South Korea and other Asian neighbours will never be satisfied.

\section{Conclusion}

One of the greatest hurdles for achieving reconciliation in Northeast Asia is addressing the disparate memories of colonial history between South Korea and Japan. Both countries continue to propagate conflicting narratives attached to those histories. Studies have shown that in the face of a shameful past, perpetrator groups may defend their identity by deleting or altering accounts of injustices from their master narratives (Bar-Tal 2003; Hammack 2008; Volpato and Licata 2010). Desire to defend collective esteem has been frequently found to drive "forgetting" of past injustices, together with an emphasis on the perpetrator group's history of victimhood. Volpato and Licata (2010) argue that "collective amnesia" is therefore a common phenomenon and a part of nation-building in many post-colonial societies.

This chapter has examined how present-day younger Japanese understand and "remember" the Asia-Pacific War, with a focus on the role of popular narratives in shaping their historical consciousness. Findings of this research indicate that Japanese collective war memory is shaped by a discourse in which Japanese civilians are treated as the war's true victims. Consistent with Orr's analysis (2001: 6), the research presented in this chapter found that the most salient victimhood narrative for the Japanese invokes the atomic bombing of Hiroshima and Nagasaki. This victimhood narrative is prevalent in Japanese public memory via official commemorations, history education and popular cultural products. The three texts most frequently cited by interviewees - The Grave of the Fireflies, Barefoot Gen, and Song of the Cane Fields - all powerfully portray the wartime sufferings of innocent Japanese civilians. Their images of civilian suffering are deeply entrenched in the Japanese consciousness and enhance a sense of victimisation. Staub (1998) warns that a victim mentality makes it difficult for a perpetrator group to view things from the victimised group's perspective, empathise with its suffering and accept responsibility for the harm inflicted by its own group. The results of this study show that the majority of participants believed their generation should not have to feel guilty for the mistakes of their forebears. Japan's victim mentality sits at the heart of East Asia conflicts and needs to be addressed if there is to be reconciliation between Japan and South Korea. 


\section{Note}

1 The survey data demonstrated a strong negative correlation between Japanese victim mentality and willingness to accept collective responsibility with $r=-78$ and significant at the 0.01 level when two-tailed.

\section{References}

Abdel-Nour, Farid. 2013. “Owning the Misdeeds of Japan's Wartime Regime”, in Inherited Responsibility and Historical Reconciliation in East Asia, edited by Jun-Hyeok Kwak and Melissa Nobles. New York: Routledge: 23-37.

Abe, Shinzo. 2006. Utsukushii kuni e [For a beautiful country]. Tokyo: Bungei Shunjū.

Abe, Shinzo. 2015. "70th Anniversary Statement by Prime Minister Shinzo Abe", 14 August. japan.kantei.go.jp/97_abe/statement/201508/0814statement.html.

Bar-Tal, Daniel. 2000. Shared Beliefs in a Society: Social psychological analysis. Thousand Oaks, CA: Sage.

Bar-Tal, Daniel. 2003. "Collective Memory of Physical Violence: Its contribution to the culture of violence", in The Role of Memory in Ethnic Conflict, edited by Ed Cairns and Michael D. Roe. Houndmills, England: Palgrave Macmillan: 77-93.

Baumeister, Roy F. and Hastings, Stephen. 1997. "Distortions of Collective Memory: How groups flatter and deceive themselves", in Collective Memory of Political Events: Social psychological perspectives, edited by James W. Pennebaker, Dario Paez and Bernard Rimé. Mahwah, NJ: Erlbaum: 277-293.

Bilali, Rezarta and Ross, Michael A. 2012. "Remembering Intergroup Conflict", in The Oxford Handbook of Intergroup Conflict, edited by Linda R. Tropp. New York: Oxford University Press: 123-135.

Branscombe, Nyla R. and Anca M. Miron. 2004. "Interpreting the Ingroup's Negative Actions Toward an Outgroup: Emotional reactions to appraised harm", in The Social Life of Emotions, edited by Larissa Z. Tiedens and Colin W. Leach. New York: Cambridge University Press: 314-335.

Brooks, Roy L. 1999. When Sorry isn't Enough: The controversy over apologies and reparations for human injustice. New York: New York University Press.

Buckley-Zistel, Susanne. 2006. "Remembering to Forget: Chosen amnesia as a strategy for local coexistence in post-genocide Rwanda". Africa: Journal of the International African Institute, 76 (2): 131-150.

Clements, Kevin P. 2018. Identity, Trust, and Reconciliation in East Asia: Dealing with painful history to create a peaceful present. Cham, Switzerland: Palgrave Macmillan.

Dudden, Alexis. 2008. Troubled Apologies among Japan, Korea and the United States. New York: Columbia University Press.

Frijda, Nico H. 1994. "The Lex Talionis: On vengeance”, in Emotions: Essays on emotion theory, edited by Stephanie H. M. Van Goozen, Nanne E. Van de Poll and Joseph A. Sergeant. Hillsdale, NJ: Lawrence Erlbaum: 263-289.

Hammack, Phillip L. 2008. "Narrative and the Cultural Psychology of Identity". Personality and Social Psychology Review, 12 (3): 222-247.

Kelman, Herbert C. 2008. "Reconciliation from a Social-Psychological Perspective", in The Social Psychology of Intergroup Reconciliation, edited by Arie Nadler, Thomas E. Malloy, and Jeffrey D. Fisher. New York: Oxford University Press: 15-23. 
Kwak, Jun-Hyeok and Melissa Nobles. 2013. “'Inherited”” Responsibility and Historical Reconciliation", in Inherited Responsibility and Historical Reconciliation in East Asia, edited by Jun-Hyeok Kwak and Melissa Nobles. New York: Routledge: 3-19.

Lederach, John P. 1997. Building Peace: Sustainable reconciliation in divided societies. Washington, DC: United States Institute of Peace Press.

Lindner, Evelin. 2006. Making Enemies: Humiliation and international conflict. London: Praeger Security International.

Liu, James H. and Denis J. Hilton. 2005. "How the Past Weighs on the Present: Social representations of history and their role in identity politics". British Journal of Social Psychology, 44: 537-556.

Miller, David. 2007. National Responsibility and Global Justice. Oxford: Oxford University Press.

Minow, Martha. 1998. Between Vengeance and Forgiveness: Facing history after genocide and mass violence. Boston: Beacon Press.

Minow, Martha. 2002. Breaking the Cycles of Hatred: Memory, law, and repair. Princeton, NJ: Princeton University Press.

Moscovici, Serge. 1988. "Notes towards a Description of Social Representations". European Journal of Social Psychology, 18: 211-250.

Nadler, Arie and Nurit Shnabel. 2008. "Instrumental and Socioemotional Paths to Intergroup Reconciliation and the Needs-Based Model of Socioemotional Reconciliation", in The Social Psychology of Intergroup Reconciliation, edited by Arie Nadler, Thomas E. Malloy and Joseph D. Fisher. New York: Oxford University Press: 37-56.

Noor, Masi, Rupert J. Brown and Garry Prentice. 2008. "Precursors and Mediators of Intergroup Reconciliation in Northern Ireland: A new model”. British Journal of Social Psychology, 47: 481-495.

Noor, Masi, Nurit Shnabel, Samer Halabi and Arie Nadler. 2012. "When Suffering Begets Suffering: The psychology of competitive victimhood between adversarial groups in violent conflicts". Personality and Social Psychology Review, 16 (4): 351-374.

Orr, Joseph J. 2001. The Victim as Hero: Ideologies of peace and national identity in postwar Japan. Honolulu: University of Hawai'i Press.

Paez, Dario and James H. Liu. 2011. Collective Memory of Conflicts in Intergroup Conflicts and Their Resolution: A social psychological perspective, edited by Daniel BarTal. New York: Psychology Press: 105-124.

Scheff, Thomas J. 1994. Bloody Revenge: Emotions, nationalism, and war. Boulder, CO: Westview.

Seaton, Philip A. 2007. Japan's Contested War Memories: The 'memory rifts' in historical consciousness of World War II. London and New York: Routledge.

Shibata, Ria. 2016. "Japan's Identity Crisis and Sino-Japanese Relations”, in Disasters and Social Crisis in Contemporary Japan: Political, religious, and cultural responses, edited by Mark Mullins and Koichi Nakano. Basingstoke, UK: Palgrave Macmillan: 81-103.

Shibata, Ria. 2017. "Memories of War and Japanese 'Historical Amnesia'”. Education and Society, 35 (1): 5-25.

Shibata, Ria. 2018. "Apology and Forgiveness in East Asia", in Identity, Trust, and Reconciliation in East Asia: Dealing with painful history to create a peaceful present, edited by Kevin P. Clements. Cham, Switzerland: Palgrave Macmillan: 271-297.

Staub, Ervin. 1998. "Breaking the Cycle of Genocidal Violence: Healing and reconciliation", in Perspectives on Loss, edited by John H. Harvey. Washington, DC: Taylor \& Francis: 231-241. 


\section{Ria Shibata}

Tajfel, Henri and Turner, John C. 1986. "The Social Identity Theory of Intergroup Behavior", in Psychology of Intergroup Relations, edited by Stephen Worchel and William G. Austin. Chicago: Nelson-Hall: 7-24.

Volkan, Vamik D. 2001. "Transgenerational Transmissions and Chosen Traumas: An aspect of large-group identity". Group Analysis, 34: 79-97.

Volpato, Chiara and Laurent Licata. 2010. "Introduction: Collective memories of colonial violence". International Journal of Conflict and Violence, 4: 4-10.

Yoshida, Yutaka. 2005. Nihonjin no sensōkan: Sengoshi no naka no hen'yō [Japanese perception of the war: Changes within postwar history]. Tokyo: Iwanami Gendai Bunko. 


\section{Index}

Abe, Shinzo 6, 7, 10, 48-49, 51-52, 57, $58,80,89,105,182,186,188$

Age of Shadows 10, 64, 66-70, 72-75

Air Doll 11, 93-97, 99-100, 102-103, 105

Amsal see Assassination

anime 3, 95, 97-99, 106, 153-158, 164-165, 191

Anpo see US-Japan Security Treaty apology 83, 85; in Japan-South Korea

Joint Declaration 5; from Japan to

Asian victims 80, 194; Korean

demands for 194; K-pop celebrities

168-169, 171, 173-174, 176, 178; over

Japanese colonisation of Korea 7, 80;

over the comfort women 194; Prime

Minister Murayama 80; in

reconciliation 85; South Korean

demands for 194

apology fatigue 195

“Arirang" 70, 81, 84, 86-88

Arirang Mass Games 38

Article 9, 80, 105

Asahi Shimbun 115-117, 121

Asian Liberation theory 55-56

Asia-Pacific War 12, 48-49, 55-56, 65,

78-80, 185, 188, 190, 195

Assassination 10, 64, 67-76

atom bomb 81, 176, 187, 189, 191-192

audience $52,66,71-75,80-81,84-88,94$, $114,118-119,121,128,133,153,155$, 159-161, 163, 165, 175-176

auto-paparazzification 172

Bae, Yongjoon 171

Barefoot Gen 13, 192, 195

Battle of Okinawa 187, 191-192

belonging 9, 36, 40-41, 44

Brotherhood of War 101

BTS 172, 176, 179 calendar (Western): adoption in non-West 19; introduction to Japan 20;

introduction to Korea 9, 19-21, 27-28

calendar, Ming dynasty 20

celebrities $13,167-173,175,177-178$

celebritisation 170

China 3, 8, 21, 43, 49-50, 54, 56, 79, 102, $127,154-155,158,160,174-175$

Chōsen Shimbun 21, 23

Chŏson Ilbo 21, 26, 117

Clouds above the Hill 9, 48-58

Cold War 9, 35, 44, 63, 129, 131-132, 134

collaborators, pro-Japanese $78,84,87$; in

Korean films 64, 66-70, 72-75, 78, 84, 87

collective memory $10,69-70,75,80,138$, 146-147, 177, 183-184, 190, 193

colonial Korea 20, 64, 70, 73

colonial modernity 67

colonial past $8,63-64,66,69-70,72-73$, $75,102,146$

colonial subject (s) 9, 19, 24, 27, 37, 64, 70-71, 83-84, 88, 90

comfort women 5-6, 11, 65-66, 68, 79-80, $85,95,97,102-105,137,139,182$,

185-188, 190, 194-195

commemoration 89

Cool Japan 3, 97-100, 104-105

Coréennes 117

cultural memory 10-11, 51, 66, 70, 72, 146

dark heritage $143,147-148$

defeat (of Japan in 1945) 37, 49, 51, 58, $70,79,115$

digital technology 1,148

divided families, between Japan and North

Korea 9, 34-35, 44

Dokdo 5, 68, 148, 153, 171 


\section{DPRK see North Korea}

East Asia 7, 13, 35, 56, 112, 139, 158, 167 , 169-171, 174, 177-178, 183, 195 emotion (s) 12, 85-86, 89, 112, 119 , 124-125, 128, 131-134, 174, 177-178

exchange, between Japan and North Korea 34, 44, 170; popular culture between Japan and South Korea 170

family (ies) 9, 34-36, 38-44, 80, 82, 84-85, 113-114, 117, 122, 134, 142, $148,191-192$

fancom 172

fans, Boys' Love manga 159; and celebrities 13, 170-171; enka 129, 133; Hetalia 13, 154, 156, 158, 160-161, 163; Japanese 129, 133, 168, 171, 175-176, 179-180; K- pop 13, 100-101, 168-172, 175-176, 178; manga and anime $155,158-159$

FIFA World Cup 5

film noir $72-73$

Firefly 10-11, 78-89

Folk Crusaders 12, 124, 130-133

food 9, 35-41, 44, 101, 113, 141, 143, 145, 175

forced labour 6, 137, 139-140, 142, 144-145, 147; site of Korean 137, 142 freedom fighters $65,67,70-72,74-75$

Fujioka, Nobukatsu 55-56

G-Dragon 167, 175-176, 180

gender, Air Doll 93, 104; Boys Love 159; in Cool Japan 99; South Korean netizens' battle over inequality 173

Girls' Generation 106, 171, 174-175

globalisation 3, 6, 171

grassroots $1-2,35,183$

Gunkanjima 12, 137-149

Hallyu 3, 70, 97, 100-102, 105, 122, 174

Hankyoreh 48

Hashima Island see Gunkanjima

Ha, Yeon-soo 169

hero, byakkotai as 161; An Chunggŭn as

173; in film noir 74; Japanese kamikaze as $10-11,78-80,84,89-90$; in Korean films 67; Korean kamikaze as 87

Heroic Corps 64-66, 71-75

Hetalia 153-164

historical memory $1,7,58,85,90,104$, 175,183

Hotaru see Firefly
Hyeri 168-169, 174

HyunA 169, 179

ICRC (International Committee of the Red Cross) 34-35, 42

identity, collective 58, 70, 90, 132, 169; and collective memory 183 ; and emotion 132; fan 163; and food 35-36, 41; in-group 184; Japanese 50, 57, 129; in Korean cinema 69-70, 72, 74; Korea under colonisation 4, 83-84, 86, 88-89, 94; and music 124-125, 129; national 8, $11,63,68-69,133,138,146,162-164$, 170, 178; North Korean 40, 125, 127-128, 133; pan-Korean 12, 132; perpetrator 184, 195; social theory 183 ; South Korean 7, 68, 70, 94, 133, 146, 169, 173; youth 131-132

Igarashi, Yoshikuni 83, 94

"Imjin River" 11-12, 124-133

imperialism, Japanese 10, 56, 112, 147

Imperial Japan 37, 63, 65-67, 190

Imperial Japanese Army 13, 19, 65, 68, 182,187

informal life politics $34-35,44$

inherited responsibility $13,182-197$

Instagram 175, 177

International Committee of the Red Cross see ICRC

international relations $1-2,6,14-15,154$, $163,174,178$

Ishihara, Shintaro 87, 105

I Will Go and Die for You 10-11, 78-81, 84, 87-90, 92

Japanese colonisation of Korea 4-5, 7, $9-10,24,28,63,65,80,83,85,116$, 118-119, 133, 137, 139, 184, 186-187

Japanese Empire 9-10, 58, 74, 80, 84-86, 88,90

Japanese film (s) 10-11, 102, 104

Japanese government 6, 9, 35, 37, 42, 45, 72, 97-98, 130, 139-140, 144, 146

Japanese military 4, 81, 84, 88, 103, 186

Japanese popular culture 3, 93, 97, 105, 147

Japan-Korea Friendship Year 5-7

Japan Times 22, 24-25, 115

JYP Entertainment 174

kamikaze 10-11, 78-90

Kanghwa Treaty 20, 54

Kan, Naoto 48, 57

Kim, Dae Jung 5 
Kim, Il Sung 126-127

Kingston, Jeff 167-168

kinship 34-35, 41, 44, 172

Koizumi, Jun'ichiro 5, 81

Kono statement 5

Korean cinema 10, 63, 65-66, 69-70, 102-103

Korean kamikaze 10, 78-81, 83-84, 87, 89-90

Korean partition 12, 131, 133-134

Korean War 101, 116, 119

Korean Wave see Hallyu

Korean Workers Party (KWP) 38

Lee Myung-bak 6

Letters, exchanged between North Korea and Japan 9, 34-35, 38-39, 41-45

\section{Mainichi Shimbun 122}

nanga 3, 79, 95-97, 99, 102, 154-161, 164, 192

Marker, Chris 117

market, of enka 129; global 102, 104; Japanese 23, 101, 106, 171; Korean 23, 65, 68; trans-Asian 105

media, Japanese 28, 38, 45, 79, 100-101, 104, 106, 156, 195; South Korean 96, $104,128,171$

Meiji industrialisation 139-140, 143, 146

Meiji Industrial Revolution 137-138, 140, 149

Meiji period 4, 10, 12, 48-53, 55, 57-58, 60, 142, 147

Meiji Restoration 20, 51, 57

memory, site of $12,138-139,145$

memory work 138

migration, between Japan and North Korea 34-35, 44-45; of Koreans to Manchuria 25

Miljŏng see Age of Shadows

Mitsuyama, Fumihiro see Tak Kyunghyun

modernity 4, 9, 22, 25-26, 28, 64-67, $69-73,75,105,141$

momgap 171

Moon, Jae-in 6-7

nationalism, affirmative 51, 59; in East Asia 167; Japanese 51, 55, 102, 105, 147; Korean 7, 13, 59, 64, 69, 84, 147, 154; popular 3; in South Korea and Japan 13, 137, 170

national narrative (s) $83,85,137$

national pride $80,118,142,147$ nationalist 51, 54-55, 57, 63, 67, 70-71, $84,87,89-90,95,102,129,131,154$, 168-169, 173-174, 178

navy, Japanese 48

NHK 49-52, 55-56, 100, 129

Nian-chan 115

normalisation, between Japan and South Korea 4, 6, 8, 11, 111-112, 116

Normalisation Treaty see Treaty of Basic Relations between Japan and South Korea

North Korea 35, 38, 40, 42, 45-47, 112, 116, 135-136; and Japan 9, 34, 43-44; music 12, 125-128, 130-131, 133; propaganda 44; relationship with Japan 34, 37-38, 44-46, 112; relationship with South Korea 11; returnees to Japan 34; return migrants to $3,9,11-12,34-35$, $37-44,112,115,124-128,130-131$, 133; schools in Japan 12, 130; selfreliance (Juche) ideology 127

Obuchi, Keizō 5

official narrative 51-52, 56, 58

Ore wa kimi no tame ni koso shini ni iku see I Will Go and Die for You

Ōshima, Nagisa 111, 117-123

otaku 95, 97-99, 101, 104, 155, 158-159, $161,163,165$

Pacific War see Asia-Pacific War parasocial kinship 172

Park, Chung Hee 4, 6, 14, 19, 68, 113, 123

Park, Geun-hye 6, 10, 68

perpetrators 83, 85, 90, 146, 182, 184, 194

popular song (s) 125, 127, 135

Port Arthur Massacre 55

ppalli ppalli 19

produsage see prosumer

prosumer 170, 172

public memory $12,138,191,195$

punctuality 9, 19-21, 25-26, 28-29

Pusan Ilbo 22

reconciliation, between Korea and Japan 1, 4-7, 10-11, 13, 49, 58, 79, 83-90, 132, 170, 177, 184, 195; fictional 83;

imagined 83; institutional 85; intergroup 182, 196-197; postcolonial 49; symbolic 85; thick 182

repatriations $37-38,45$

revisionism 142

revisionist 51, 63, 79, 81, 83, 90, 144, 188

Rising Sun Flag 88-89, 167-170 
ROK see South Korea

ROK-Japan Treaty see Treaty of Basic Relations between Japan and South Korea

Russo-Japanese War 48, 53-54, 56, 175

sacrifice 11, 25, 122, 141-142

Saka no ue no kumo see Clouds above the Hill

San Francisco Peace Treaty 37, 45

Sankei Shimbun 48, 51

Second World War 4-5, 12, 37, 103, 112, $129,137,155,160,184-185,187$

Shiba Ryōtarō 9-10, 48-52, 54-56, 58; Memorial Museum 49

Shiba shikan (Shiba view of history) 9, 48-58

Showa Emperor 80-81, 190

Showa period 49, 51, 141

Sino-Japanese War 48, 54

snapchat 13, 167, 171, 175

Sore Maji Nippon 140-142, 144, 146-147

South Korea 3-8, 11-13, 35, 38, 41, 63, 66, 101-102, 105, 111-122, 124, 126, $128,130,133,158,161-162,167-168$, $170-177,195$

Sunny 175

t'aegǔkki (South Korean national flag) 174-176

T'aegŭkki Hwinallimyŏ see the Brotherhood of War

Takeshima see Dokdo

Tak Kyung-hyun 81, 87, 89-90

television 10, 52, 118, 137-138, 145, 154, 187, 190, 192-193

Tiffany $13,167-169,171-175$

Time Day 21-23

timeliness 19, 21, 26, 28

Tonga Ilbo 21-23, 26, 111 tourism 9, 52-53, 56-57, 59, 79, 137, 148-149

touristification $52,55,57$

tourist sites $10,49,52-53,56-57$

Toyotomi Hideyoshi 4

trauma $66,70,74,81-83,86,94,129$, $132-133,143-145,169,176,182-184$

Treaty of Basic Relations between Japan and South Korea 4, 114, 116-117, 120

Twice 22, 174

Tzuyu 174

ultra-nationalism 79

US-Japan Security Treaty 119

victim (s) 6, 11, 78, 80-81, 83-85, 87, 89-90, 112, 116, 119, 144-146, 163, $169,182,184,189-192,194-195$

victimhood 11-12, 80, 112, 119, 121, 143-144, 146-147, 184, 188, 191-193, 195

victimisation $85,112,140,182,184-185$, 195

victimiser (s) 78, 81, 83-84, 90, 116, 144-146, 189

victim mentality 193,195

victim narratives 184

victim/victimiser 90, 143-144

war memory $10,78-79,81,86,89,138$, 190, 195

war responsibility 80

Winter Sonata 5, 100-101

wristwatch 26, 39

Yasukuni Shrine 5, 137, 139, 142, 183

Yeun, Steven 173, 178

Yomiuri Shimbun 117, 121

Yunbogi's Diary 111-123

zainichi 12, 35, 38, 44, 113, 115, 122, 126, $128,130-133$ 